\title{
Intersekcijska analiza uloge i položaja rovinjskih industrijskih radnica u razdoblju 1872.-1970.
}

\section{Nikolić Đerić, Tamara}

Doctoral thesis / Disertacija

2020

Degree Grantor / Ustanova koja je dodijelila akademski / stručni stupanj: University of Zagreb, University of Zagreb, Faculty of Humanities and Social Sciences / Sveučilište u Zagrebu, Filozofski fakultet

https://doi.org/10.17234/diss.2020.7418

Permanent link / Trajna poveznica: https://urn.nsk.hr/urn:nbn:hr:131:564811

Rights / Prava: In copyright/Zaštićeno autorskim pravom.

Download date / Datum preuzimanja: 2023-04-26

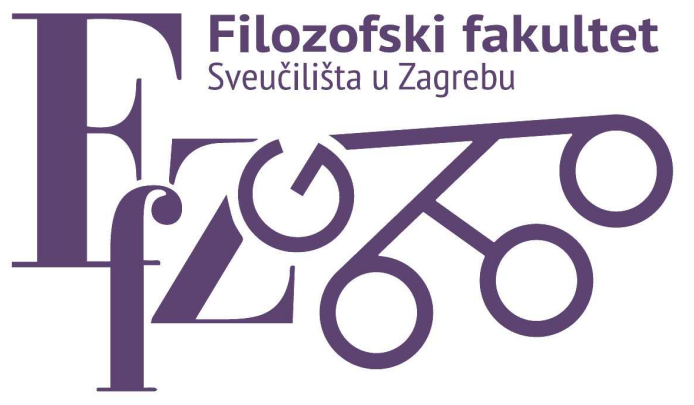

Repository / Repozitorij:

ODRAZ - open repository of the University of Zagreb Faculty of Humanities and Social Sciences
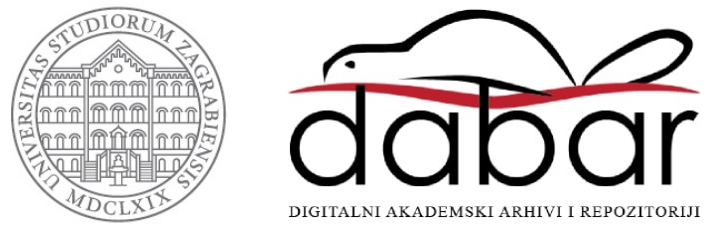


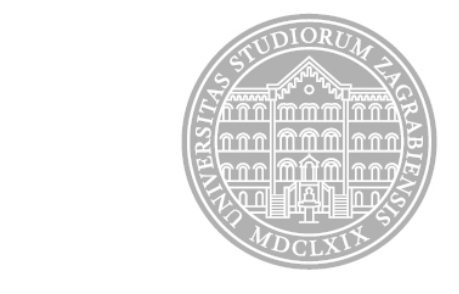

Sveučilište u Zagrebu

Filozofski fakultet

Tamara Nikolić Đerić

\section{INTERSEKCIJSKA ANALIZA \\ ULOGE I POLOŽAJA ROVINJSKIH \\ INDUSTRIJSKIH RADNICA U \\ RAZDOBLJU 1872.-1970.}

DOKTORSKI RAD

Zagreb, 2019. 


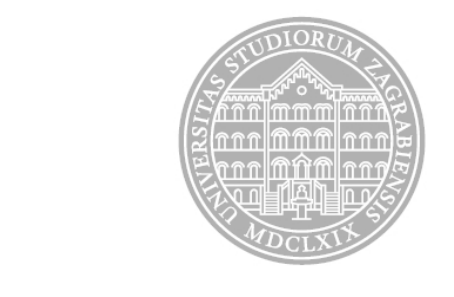

University of Zagreb

Faculty of Humanities and Social Sciences

Tamara Nikolić Đerić

\section{INTERSECTIONAL ANALYSIS OF THE ROLE AND POSITION OF ROVINJ INDUSTRIAL WOMEN WORKERS IN THE PERIOD FROM 1872-1970}

DOCTORAL DISSERTATION

Zagreb, 2019 


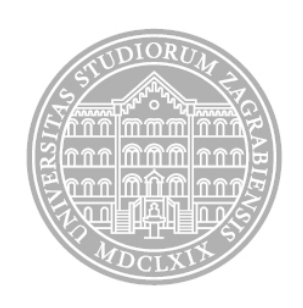

Sveučilište u Zagrebu

Filozofski fakultet

Tamara Nikolić Đerić

\title{
INTERSEKCIJSKA ANALIZA \\ ULOGE I POLOŽAJA ROVINJSKIH \\ INDUSTRIJSKIH RADNICA U \\ RAZDOBLJU 1872.-1970.
}

\author{
DOKTORSKI RAD \\ Mentor: \\ dr. sc. Tea Škokić, viša znanstvena suradnica
}

Zagreb, 2019. 


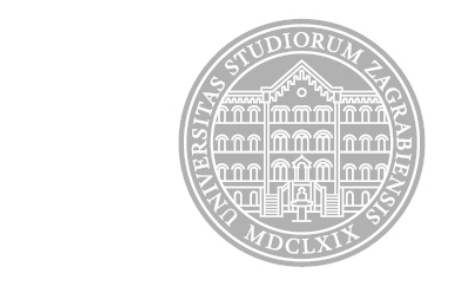

University of Zagreb

Faculty of Humanities and Social Sciences

Tamara Nikolić Đerić

\title{
INTERSECTIONAL ANALYSIS OF THE ROLE AND POSITION OF ROVINJ INDUSTRIAL WOMEN WORKERS IN THE PERIOD FROM 1872 TO 1970
}

\author{
DOCTORAL THESIS \\ Supervisor: \\ Tea Škokić, PhD, Senior Research Associates
}

Zagreb, 2019 


\section{ZAHVALA}

Iskreno se zahvaljujem kazivačicama i kazivačima, posebno gospođi Anni Delii Quarantotto na dugogodišnjoj suradnji i strpljenju, a zatim mentorici dr. sc. Tei Škokić na povjerenju i stručnoj podršci, te kolegici dr. sc. Sandri Urem na nesebičnoj pomoći i savjetima u fazi pisanja rada.

Uz njih, zahvala ide i svima ostalima koji su na različite načine i u različitim periodima doprinijeli realizaciji ove disertacije: Ravnateljici Etnografskog muzej IstreMuseo etnografico dell'Istria, dr. sc. Lidiji Nikočević, kolegicama Nikolini Rusac i dr. sc. Ivoni Orlić, gospođi Kristini Miljavac - Adris grupa d.d., gospođi Mariji Božinović, djelatnici Doma za odrasle "Domenico Pergolis" iz Rovinja, kolegi arhivistu Gordanu Grzunov, Muzeju Grada Rovinja-Rovigno na čelu s kolegicom Tajanom Ujčić, te Ivani Čehić Rabljenović.

Kako šećer uvijek ostavljam za kraj, konačno se od srca zahvaljujem i svojoj obitelji na ljubavi i potpori koju mi svakodnevno pružaju, čineći tako ovaj i sve druge profesionalne podvige lakšima i smislenijima.

Ovaj rad posvećujem nonni Marii Giuricin i svojoj djeci Zoji i Maksimu. 


\section{SAŽETAK}

Tema rada je analiza uloge i položaja industrijskih radnica u Rovinju od osnutka dvaju najvećih tvorničkih pogona, duhanskog i ribljeg, (1872. i 1877.) do 1970. godine. Definiranim vremenskim okvirom moguće je pratiti značajnije društveno-političke (Austro-Ugarska, Kraljevina Italija i SFRJ) i tehnološke (od manufaktura do suvremene mehanizacije okarakterizirane radom na traci) promjene s reperkusijama na društveni položaj radnica.

Rad započinje pozicioniranjem autorice kroz prizmu feminističke antropologije. Propitivanjem pitanja objektivnosti i insajderskog terena, autorica definira njoj najprikladniju metodologiju, a koja se ogleda u kombinaciji povijesne metode i etnografskog terena, te pozicioniranom znanju i intersekcionalizmu kao metodološkom, ali i teorijsko analitičkom okviru. Industrijska antropološka misao i feminističke teorije $\mathrm{s}$ fokusom na revidiranu stanpoint teoriju i intersekcionalizam se od početka pregleda uspoređuje sa saznanjima formiranima na temelju terenskog rada, a sve kako bi se zadržala jasna poveznica metodološko-teorijskog okvira i empirijskog istraživanja. Autorica posebnu pažnju pridaje upravo konstruktivističkoj prirodi znanja o radnicama i/ili ženama uopće, te su stoga sadržaj i tema istraživanja, metodologija i teorija dio jednog pisma i jedne poruke.

U četvrtom poglavlju, analizom povijesnih pisanih izvora; Knjige radnica TDRa, te matičnih knjiga rođenih, vjenčanih i umrlih za period od 1816. do 1907. godine, odnosno 1913. za knjige umrlih, autorica ukazuje na nevidljivost ženskog rada kroz javne spise i smješta ih u opći historiografsku tezu o nevidljivost žena kroz povijest.

U Rovinju se društveni položaj žena drastično mijenja razvojem industrijalizacije krajem 19. stoljeća pa se kao izvor za razumijevanje navedene promjene, specifične za mikro-lokalitet, analiziraju ranija istraživanja položaja žena $\mathrm{u}$ Istri s posebnom fokusom na instituciji "braka na istarski način”. Isti se sagledava kao mogući izvor povoljnijeg društvenog statusa žena i prije industrijalizacije.

Intersekcijskom analizom statusa radnica krajem 19. i početkom 20. stoljeća, temeljenom na pisanim izvorima, sjećanjima kazivača, te življenih iskustva radnica koja predstavljaju empirijski dio kvalitativnog etnografskog istraživanja, radom se istražuju 
mehanizmi tvorbe i presijecanja različitih identiteta (rodni, nacionalni i klasni kao najzastupljeniji) unutar radničke grupe. Naglasak istraživanja je na artikulaciji heterogenosti radničkih iskustava, posebice na razini interpretacije (društvenog) sjećanja nasuprot življenog iskustva.

Rad završava analizom koncepta kulturnog pamćenja na temelju suvremene percepcije uloge i položaja industrijskih radnica u periodu obuhvaćenom istraživanjem.

Ključne riječi: radnice, industrijalizacija, intersekcionalizam, situirano znanje 


\section{SUMMARY}

The topic of this dissertation is the analysis of the role and position of female industrial workers in Rovinj since the establishment of the two largest industrial plants for processing tobacco (1872) and fish (1877) until 1970. By defining this time frame, it is possible to follow the most important changes affecting the social status of female workers: social and political changes (Austro Hungarian Empire, Kingdom of Italy and Socialist Federal Republic of Yugoslavia), technological changes (from workshops to contemporary mechanisation characterized by the use of assembly lines).

The paper begins with the author's positioning through the prism of feminist anthropology. By questioning objectivity and insider knowledge, the author defines her most suitable work methodology, reflected in the combined employment of a historical method and ethnographic background, along with situated knowledge and intersectionality as a methodological, theoretical and analytical framework. From the very beginning, the industrial anthropological thought and feminist theories focusing on the revised standpoint theory and intersectionality are compared with insights gained through fieldwork in order to maintain a clear link between a methodological and theoretical framework and empirical research. The author especially focuses on the constructivist nature of information about female workers and/or women in general. Therefore, the content and topic of the research as well as the methodology and theory are all part of one and the same message.

In the fourth part, the author analyses historical sources: the register of female workers employed by TDR (Rovinj Tobacco Factory), birth and death records as well as marriage registers for the period between 1816 and 1907 (1913 for death records). The author shows the invisibility of female work through public records, thus placing them in the general historiographic thesis about the invisibility of women through history.

The social status of women in Rovinj dramatically changed due to industrialization developments by the end of the $19^{\text {th }}$ century. In order to understand these changes (specific for this micro-location), the author also analyses earlier research into the position of women in Istria, focusing especially on the institution of the "Istrian 
marriage" - the latter is seen as a likely means to achieve better social status for women even before industrialization.

By employing intersectionality when analysing the status of female workers at the end of the $19^{\text {th }}$ and beginning of the $20^{\text {th }}$ century through written sources, informants' memories and female workers' experiences representing the empirical part of the qualitative ethnographic research, this paper discusses the mechanisms at work in the creation and intersection of different identities: gender-, national- and class-related (the latter being the most prominent) within a workers' group. The research focuses especially on expressing the heterogeneity of workers' experiences, especially when it comes to interpreting (social) memory versus lived experience.

The paper ends with the analysis of the concepts of cultural memory based on the contemporary perception of the role and status of female industrial workers in the period included in this research.

Key words: female workers, industrialization, intersectionality, situated knowledge 


\section{SADRŽAJ}

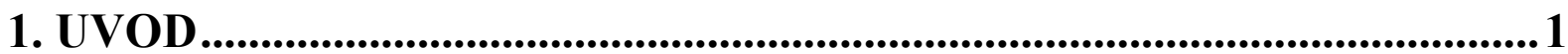

1. 1. Pozicija žena na tržištu rada danas: poticaj istraživanju.................................1

1. 2. Istraživačka pitanja ...............................................................................4

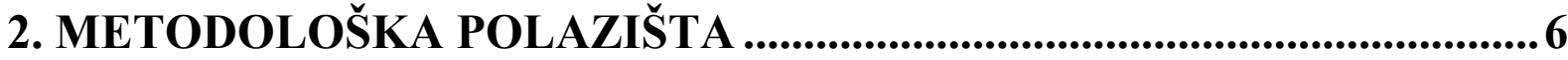

2. 1. Istraživačka pozicija: o insajderskoj etnografiji i neodgovorenom pitanju

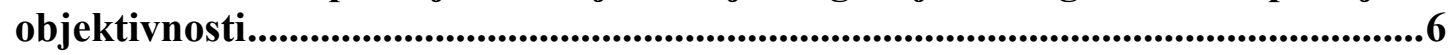

2. 2. Dizajniranje istraživanja .......................................................................16

2. 3. Kvalitativno etnografsko istraživanje polustrukturiranim intervjuom........21

2. 4. Promatranje sa sudjelovanjem ..................................................................................24

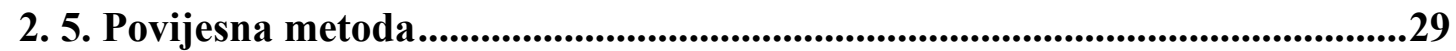

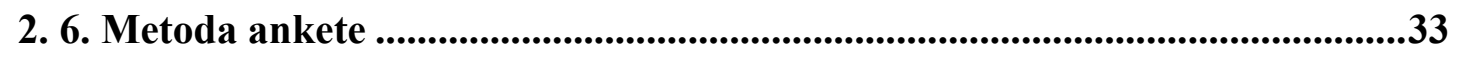

2. 7. Feministička metoda ...................................................................................................34

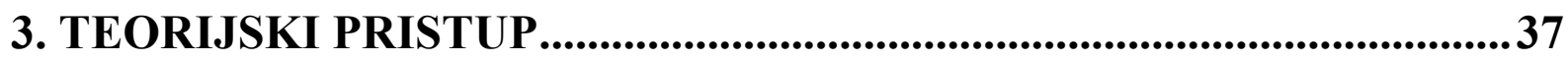

3. 1. Feministička antropologija, pregled razvoja discipline....................................37

3. 2. Situirano znanje ................................................................................................................46

3. 3. Intersekcionalizam ........................................................................................51

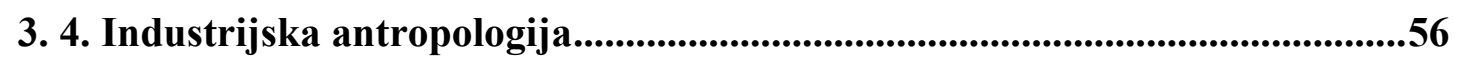

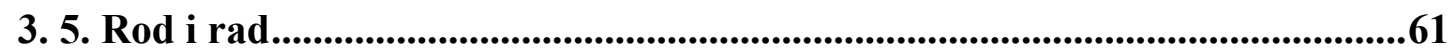

4. DRUŠTVENO-POVIJESNO SITUIRANJE PREDMETA ....................... 71

4. 1. Crtice iz ekonomske povijesti Rovinja ..............................................................71

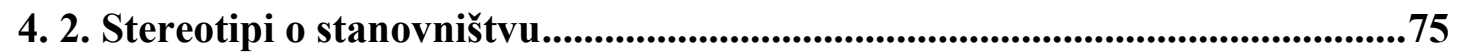

4. 3. Poslovna sposobnost žena do industrijalizacije ............................................78

4. 4. Brak na istarski način kao mogući uzrok rane emancipacije .........................83

4. 5. Uloga i pozicija žena u 19. stoljeću: intersekcijska analiza poslovne sposobnosti žena na temelju primarnih povijesnih izvora ......................................887

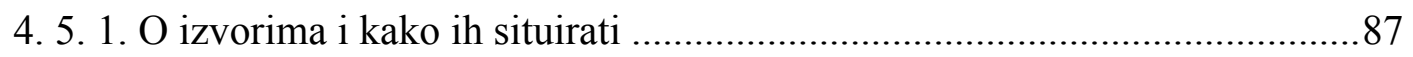

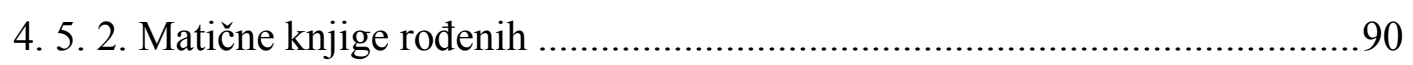

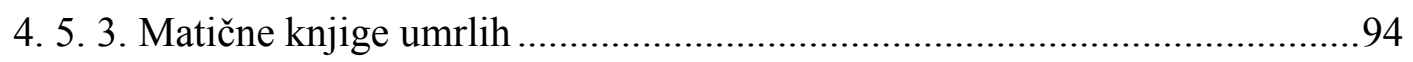

4. 5. 4. Matične knjige vjenčanih .....................................................................95

5. BITI ROVINJSKA RADNICA: intersekcijska analiza uloga i položaja rovinjskih industrijskih radnica ...................................................98

5. 1. Počeci rovinjskog industrijskog razvoja u svjetlu rastućeg kapitalizma .....98

5. 2. Primijenjeni intersekcionalizam ............................................................112

5. 3. Pisani izvori: Knjiga radnica TDR-a.............................................................116 


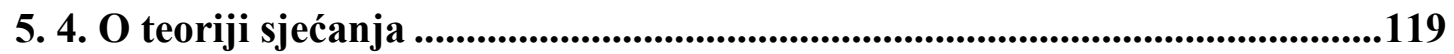

5. 5. Sjećanja nasuprot življenim iskustvima: koje je pravo lice radnice? ........122

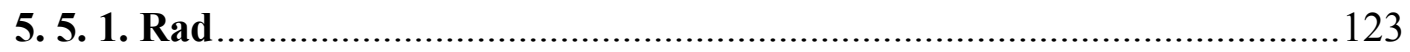

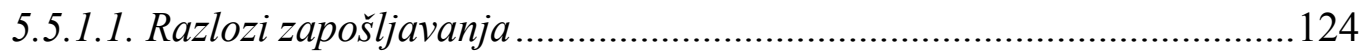

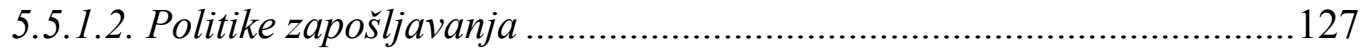

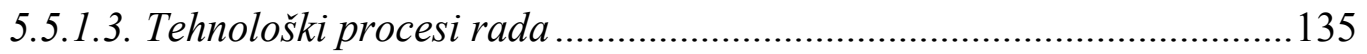

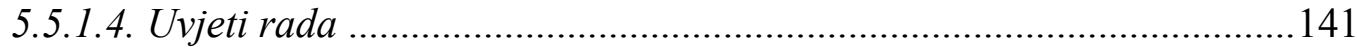

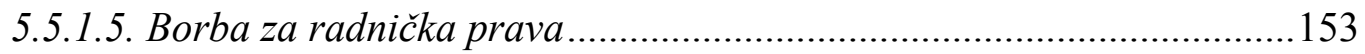

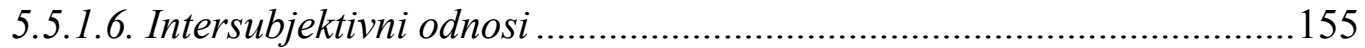

5.5.1.7. Miris duhana i smrad ribe ...................................................................159

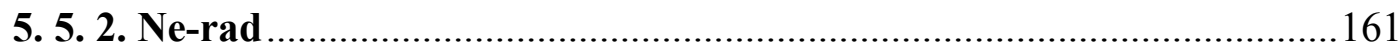

5.5.2.1. Majčinstvo i odnosi unutar obitelji ....................................................162

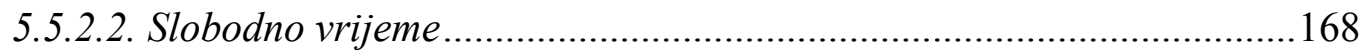

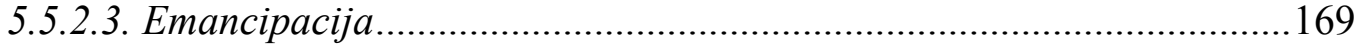

6. ŠTO ROVINJ PAMTI .............................................................................. 171

6. 1. Fotografije kao prijenosni mehanizam kulturnog pamćenja.......................173

6. 2. Folklorna građa i reprezentacijski intersekcionalizam ...............................179

6. 3. Muzeološko djelovanje na kulturno pamćenje radnica................................184

6. 4. Izgradnja korporativnog imidža uspostavom Muzeja duhana...................185

6. 5. Anketa: Pogledi na rovinjsku industrijsku prošlost ..................................189

7. ZAKLJUČAK ..........................................................................................198

8. LITERATURA I IZVORI................................................................... 212 


\section{UVOD}

\section{1. Pozicija žena na tržištu rada danas: poticaj istraživanju}

U svjetlu UN-ovih razvojnih ciljeva do 2030. godine ${ }^{1}$ rodna se ravnopravnost, $\mathrm{s}$ posebnim fokusom na poziciju žena na tržištu rada, pravo na jednaku plaću za jednaki rad kao i uspostavu ravnoteže između profesionalnog i privatnog života, sagledava kao preduvjet stabilne i transparentne demokracije. U periodu između 2016. i 2019. godine pokrenute su brojne inicijative na razini Europske komisije kako bi se stanje poboljšalo, pa je, između ostalog, 2017. godine prihvaćen set mjera za poboljšanje ravnoteže privatnog i profesionalnog života muškaraca i žena.

Usprkos tome, bitka se gubi kada je u pitanju nasilje nad ženama, ali i ekonomska i politička ravnoteža, konkretno, pitanje plaća i razine prisustva žena na ključnim pozicijama odlučivanja. Prema istraživanju i Izvješćc Eurobarometra iz 2017. godine, ${ }^{2} 84 \%$ ispitanika članica zemalja Europske unije vjeruje da je rodna ravnopravnost za njih osobno važna (87\% žena i $80 \%$ muškaraca) (Special Eurobarometer 465 2017: 10-11), međutim u isto vrijeme trećina Europljana smatra da su muškarci ambiciozniji od žena (ibid.: 14), a čak $69 \%$ ispitanika smatra da se žene u odlučivanju vode emocijama (ibid.: 5), što možemo dovesti u direktnu vezu s dominantnim očekivanjima koja se ženama nameću po pitanju privatne sfere $\mathrm{i}$ održavanja socijalne reprodukcije, odnosno brige o kućanstvu i njege bližnjih. Poražavajuća je činjenica da se napredak k dostizanju ravnopravnosti, na temelju navedenog Izvješća, odvija "puževim korakom". Posebno se uočava pad u domeni slobodnog vremena i njege bližnjih. Teret je, dakako, na ženama.

\footnotetext{
${ }^{1}$ http://odraz.hr/media/291518/globalni\%20ciljevi\%20odrzivog\%20razvoja\%20do\%202030_web.pdf, pristup 1. 9. 2019.

${ }^{2}$ Istraživanje je provedeno u 28 država članica Europske unije, između 13. i 26. lipnja 2017. godine, s 28 093 ispitanika iz različitih društvenih i demografskih skupina, a intervjuirani su u vlastitim domovima na materinjem jeziku (Special Eurobarometer 465, Summary. Gender Equality 2017 - Gender Equality, Stereotypes, and Women in Politics 2017).
} 
Te iste 2017. godine Europski institut za rodnu ravnopravnost objavio je Indeks rodne ravnopravnosti, ${ }^{3}$ koji se u posljednjih deset godina povećao za samo četiri boda te na razini EU-28 iznosi 66.2, a za Hrvatsku iznosi 53.1 od maksimalnih 100 bodova. Hrvatska se s takvom ocjenom svrstava među najlošije plasirane zemlje (EU-28) po pitanju rodne ravnopravnosti, s konstatacijom da Hrvatska sporije napreduje prema rodnoj ravnopravnosti te joj je rang ostao isti kao 2005. godine. Indeks se mjeri kroz šest domena: zdravstvo, zaposlenje, novac, vrijeme, moć, znanje i nasilje. Svaka domena ima poddomene, čija bi analiza prelazila potrebe ovog rada. Ipak, za bolje razumijevanje njegove relevantnosti u suvremenom akademskom i društvenom kontekstu te za obrazloženje istraživačke pozicije, značajno je navesti da:

- u domeni znanja rodna segregacija ostaje jedan od ključnih izazova za Hrvatsku,

- da se rezultat rodne jednakosti provođenja slobodnog vremena u smislu društvenih aktivnosti (sportske i kulturne aktivnosti te dokolica) poboljšao, međutim da se u poddomeni "vrijeme posvećeno njezi bližnjih i kućanskim poslovima" nalazimo na 27. mjestu (od 28 zemalja EU-a),

- da se po pitanju zaposlenja participacija žena povećala, ali je segregacija u domeni rada perzistentna. Ovdje je posebno zanimljivo napomenuti da je segregacija muškaraca znatna u sektoru obrazovanja i socijalnog rada, što se s druge strane može iščitati i kao prisustvo rodne stereotipizacije rada,

- da najlošiji rezultat Hrvatska ima u domeni moći, pri čemu drastično stagniraju upravo domena financijske i političke moći.

Činjenica da rodna ravnopravnost u svim segmentima, pa tako i u segmentu rada, nije dostignuta do 21. stoljeća, niti se rješenje nazire u bližoj budućnosti, svakako upućuje na potrebu sagledavanja partikularnih mikrorealnosti, kao i na potrebu ispisivanja povijesnog toka razvoja kritičkog promišljanja ženskog rada, a koje mogu poslužiti kao lekcije za budućnost. Upravo su ove dvije potrebe odredile temu i znanstvenoistraživački pristup ove disertacije. Tema disertacije je uloga i pozicija industrijskih radnica u periodu od 1872. godine, dakle od osnutka najvećeg tvorničkog pogona u Rovinju, pa sve do 1970. godine, s ciljem sagledavanja specifičnog društvenopolitičkog utjecaja na svakodnevicu radnica.

\footnotetext{
${ }^{3} \mathrm{https}$ ://eige.europa.eu/gender-equality-index/2017/HR, pristup rujan 2019.
} 
Autori koji istražuju ženski industrijski rad na prijelazu iz 19. u 20. stoljeće, dakle u vrijeme koje je ključno za razumijevanje i ovog istraživanja, usmjereni su na tri ključne teme, a koje su, ako je suditi prema spomenutom Izvješću, relevantne i danas. Najraniji fokus, odnosno prva tema tiče se oslobodilačkog potencijala rada (Gilman 1898), premda su se ekonomska stabilnost i neovisnost koje je pružao rad, odnosno zarada, uzimale bezrezervno, zaboravljajući na teškoće koje su radnice doživljavale s obzirom na društvena očekivanja u pogledu majčinske, bračne i drugih "ženskih" uloga. Analizirajući Engelsa i koncept privatnog vlasništva, Karen Sacks (1975) odlazi korak dalje te kao uzrok i potencijal za emancipaciju vidi privatno vlasništvo. Međutim, iako rad može omogućiti privatno vlasništvo, oni nisu uvijek direktno povezani. Naime, vlasništvo se stjecalo i nasljeđivanjem, ali se vlasništvo također moglo i oduzeti, ovisno o tradicijskim i društvenim obrascima. U narednom periodu istraživanja ženskog rada artikuliraju se nejednakosti unutar radničke klase temeljene na rodnoj distinkciji (Jaggar i Rothenberg 1978) i otvara pitanje kućnog rada (Federici 1975), pri čemu se posebice upozorava na to da su ženski rad i kućanski poslovi, kao i briga o bližnjima podređeni kategoriji rada ili uopće ne ulaze u tu kategoriju (McDowell 2006). Od 1980-ih istraživačice su, u skladu s postmodernističkom paradigmom, usmjerene na treću ključnu temu koja se tiče revidiranja dotadašnjih teza o ženskom homogenom iskustvu te već 1988. godine Donna Haraway upućuje na intersekcijsku perspektivu, zagovarajući politiku afiniteta/sličnosti koja bi kombinirala epistemološke perspektive.

Uvažajući ovo posljednje, posebice u kontekstu promišljanja heterogenih iskustava rovinjskih radnica, zatim uzimajući u obzir društveno-povijesne relevantnosti teorijskih promišljanja kao refleksije jednog doba, a u odnosu na period obuhvaćen istraživanjem te tokove razvoja feminističke misli kao i industrijskog razvoja $u$ ekonomskom i tehnološkom smislu, a s reperkusijama na svakodnevicu i društvenu poziciju radnika, konceptualizirala sam teorijsko-metodološki pristup istraživanju pozicije i uloge žena radnica na primjeru rovinjske industrije, a koji će biti detaljnije predstavljen u narednim odlomcima. 


\section{2. Istraživačka pitanja}

Krajem 19. stoljeća Rovinj postaje jedan od razvijenijih industrijskih gradova $u$ Istri. Specifičnost rovinjske industrije leži u tome da se kvantitativno temeljila na ženskom radu. Ta je činjenica određenom broju radnica u duhanskoj industriji omogućavala bolji društveni status, a naznake koje govore u prilog ovoj tezi nalazimo u povijesnim pisanim izvorima (Benussi 2004 [1888]). Primjerice, na samim počecima rada Tvornice duhana Rovinj (TDR) 98\% radne snage činile su žene. Za rad se prijavilo 700 osoba, zaposleno ih je 401 od čega su 391 bile žene. Pretpostavljeni privilegirani status rovinjskih radnica bio je iznimka u globalnoj (duhanskoj) industriji s kraja 19. i u prvoj polovici 20. stoljeća. U Grčkoj, primjerice, ženska radna snaga u industriji u istom je razdoblju imala negativne konotacije, a žene su zbog odluke da rade bile izložene snažnim osudama društva (Hadar 2007). Slično je bilo i u mnogim drugim europskim zemljama u kojima su žene bile uključene u industrijski rad. Stoga je pozitivno radno iskustvo rovinjskih duhanskih radnica nužno povezati s povijesnim istraživanjima Luje Margetića o braku na istarski način (1970) i Marije Mogorović Crljenko o statusu žena u kasnom srednjovjekovlju i ranom novovjekovlju u Istri (2006 i 2012), a koja ukazuju na relativno dobar i specifičan društveni položaj istarskih žena u odnosu na druge zajednice mediteranskog kulturnog kruga.

Zahvaljujući snažnom razvoju industrije u Rovinju, ali i Istri općenito, početkom 20. stoljeća u Rovinju dolazi do značajne fluktuacije radne snage koja mijenja društvenu strukturu rovinjske zajednice, diverzificirajući pritom ulogu/e i položaj industrijskih radnica. Istraživačka pitanja stoga obuhvaćaju razne aspekte radničkog iskustva žena uz pokušaj ravnomjernog sagledavanja relevantnih elemenata koji konstituiraju sferu privatnog i javnog života: jesu li žene u Rovinju zaista uživale privilegirani (društveni) status krajem 19. stoljeća?, je li tome uzrok ekonomska neovisnost?, koliko je taj status bio poštivan unutar obitelji i kako se odražavao na javno djelovanje žena?, kolika su bila fizička opterećenja rada?, na koji su način ispunjavale društveno očekivane uloge majke i radnice unutar male, dotad poljoprivredne i ribarske zajednice?, te konačno, kakvi su odnosi vladali unutar radničke klase, posebno među ženama radnicama? 
Usporedba istraživanja na geografski ograničenom prostoru Rovinja s dostupnim istraživanjima o položaju industrijskih radnica krajem 19. stoljeća na širem geopolitičkom prostoru (posebno u Velikoj Britaniji, Austro-Ugarskoj i Osmanskom Carstvu) odredila je da istraživačka pitanja dobiju širi kontekst i obuhvate pitanja o ulozi i položaju žena radnica u formativnom razdoblju hrvatske ${ }^{4}$ industrije te razloge nevidljivosti žena u procesima industrijalizacije i izuzeća ženskog industrijskog rada iz društveno-ekonomskog diskursa s kraja 19. i početka 20. stoljeća. Analizom navedenih elemenata ženskog radničkog iskustva, rad može dati smjernice za promišljanje suvremene pozicije žena radnica. Hipoteze rada su sljedeće:

1. ženski se rad u povijesnim i ekonomsko-političkim pisanjima i sjećanjima prešućuje s ciljem perpetuiranja rodnih stereotipa;

2. radnička je klasa heterogena struktura uvjetovana presijecanjem različitih identiteta (primjerice rodnog, nacionalnog i profesionalnog);

3. industrijski rad za žene ima emancipacijski potencijal samo u određenim društvenopolitičkim i povijesnim kontekstima.

\footnotetext{
4 Kako je već navedeno, rad pokriva period od osnutka najvećeg industrijskog pogona u Rovinju, Tvornice duhana Rovinj, 1872. godine sve do 1970. kako bi se sagledao društveno-politički i tehnološki utjecaj na radničku svakodnevicu. U navedenom je periodu društveno-politički okvir podrazumijevao promjenu vlasti od austrijske/austrougarske (Markgrofovija Istra 1849.-1918.) preko talijanske (1920. Kraljevina SHS prepušta Istru Italiji) do jugoslavenske (Istarski poluotok je sporazumom Jugoslavije, SAD-a i Ujedinjenoga Kraljevstva u Beogradu 1945. godine podijeljen u dvije zone, Zonu A i Zonu B. Zona A je bila pod britansko-američkom, a Zona B pod jugoslavenskom vojnom upravom. Godine 1947. Pariškim mirovnim ugovorima ukinute su Zone A i B, osnovan je Slobodni teritorij Trsta koji je sezao sve do Novigrada, a ostali dijelovi priključeni su Jugoslaviji). Tehnološki utjecaj na svakodnevicu ogleda se u tehnološkim promjenama, odnosno prelasku s manufakture na mehanizaciju, ali i druge tekovine tehnološkog napretka, posebno uvođenje hladnjača.
} 


\section{METODOLOŠKA POLAZIŠTA}

\section{1. Istraživačka pozicija: o insajderskoj etnografiji i neodgovorenom pitanju objektivnosti}

Ne postoji jedinstveno feminističko stajalište, jer naše mape zahtijevaju previše dimenzija da bi ta metafora mogla utemeljiti našu viziju (Haraway 1988: 590). ${ }^{5}$

Geografska lokacija (Rovinj) i vremenski period (1872.-1970.) odabrani su s obzirom na moje osobno iskustvo suživota $\mathrm{s}$ generacijama rovinjskih radnica te prisutnosti društvenog sjećanja na radnice. O položaju i ulozi žena radnica istraživala sam, dakle, na domaćem terenu, nalazeći kazivače među prijateljima i rodbinom, ali i neznancima na koje su me osobni kontakti upućivali, slijedeći tako metodologiju snježne grude. ${ }^{6}$ Takvim su se odabirom otvorila dva ključna epistemološka i metodološka problema, a koja su obilježila dugogodišnji proces istraživanja i interpretacije podataka koji se u radu izlažu; problem insajderske etnografije i problem objektivnosti takve etnografije, odnosno objektivnosti u kontekstu konstrukcije znanja uopće. Osim poznate lokacije (domaći teren) koja me u klasičnom etnološkometodološkom smislu prepoznala kao insajdericu, svoju pripadnost istraživanom predmetu promatrala sam kroz rodnu (kao žena) i profesionalnu (kao radnica) prizmu. S obzirom na to da je u procesu istraživanja osviješten snažan utjecaj (domaćeg) terena na profesionalni i privatni razvoj istraživačice te vrijednost samog procesa terenskog istraživanja u odnosu na finalni rezultat, značajan se dio ovog dijela rada bavi upravo promišljanjem vlastite istraživačke pozicije. Ona se u općim crtama izlaže s ciljem opravdavanja konstrukcijske naravi znanja i nužnosti razjašnjavanja pozicije moći iz koje se u istraživanje ulazi (usp. Potkonjak 2014), ali kojom se također žele propitati opća mjesta insajderske etnografije i moguće zamke domaćeg terena, kao i mogućnost alternativnog istraživačkog pozicioniranja. Naime, iako osobne predispozicije, kao i najrazličitije društveno-političke okolnosti utječu na svako istraživanje, neovisno govorimo li o stranom ili domaćem terenu, po pisanjima brojnih autorica (Čapo-Žmegač

\footnotetext{
${ }^{5}$ Svi prijevodi u disertaciji su autoričini, osim ako nije drugačije navedeno.

6 "Metoda uzorkovanja koja se temelji na ciljanome odabiru uskoga kruga ljudi koji zatim šire uzorak, upućujući istraživača na druge osobe koje bi mogao ispitati" (http://struna.ihjj.hr/naziv/metoda-snjeznegrude/20469/).
} 
2006; Gulin Zrnić 2005; Kondo 1990; Narayan 1993; Favret-Saada 2012) problematika domaćeg terena može značajnije opteretiti istraživanje, komunikaciju i restituciju rezultata s osobnim posljedicama za same istraživače.

Pozitivne strane insajderskog istraživanja posebno je naglasio John L. Aguilar, sada već davne 1981. godine. Sanja Potkonjak navodi kako upravo Aguilar insajderskoj etnografiji pripisuje dozu privilegirane pozicije s obzirom na to da insajderski istraživač dijeli znanje s članovima grupe koju istražuje. To je znanje utemeljeno na življenju u kulturi i razumijevanju eksplicitnih kao i implicitnih kulturnih pravila, neizgovorenih osjećaja i stavova, onoga što se u kulturi podrazumijeva (Potkonjak 2014: 28).

I sama sam, kao mlada, tek diplomirana etnologinja i s nekoliko mjeseci iskustva rada u Etnografskom muzeju Istre-Museo etnografico dell'Istria, uz stručnu podršku dr. sc. Lidije Nikočević, smatrala kako je pitanje rovinjskih radnica i rad na domaćem terenu profesionalno izazovno iskustvo, jer sam dotad terenska istraživanja provodila izvan domene geografski "bliskog", ali me istovremeno tištala pomisao o (pretpostavljenoj) homogenosti teme i svjetonazora ispitanika, a koja će mi otežati zadovoljavanje kriterija znanstvenog doprinosa tog istraživanja (usp. Strathern 1987: 17). Iako "insajderica", u samom početku nisam osvijestila nužnost autokulturne defamilijarizacije ili poetskog očuđivanja, ${ }^{7}$ kako ga Valentina Gulin Zrnić naziva. Očuđivanje, odmak od terena (engl. stepping out) i racionalizacija pounutrašnjenog znanja, povijesti i iskustava (usp. Gulin Zrnić 2005: 170) pokazali su se neizostavnima tek tijekom terenskog rada. Međutim, promišljajući vlastito terensko iskustvo $\mathrm{s}$ određenom vremenskom distancom, pitam se je li takav odmak uopće moguć.

Početna istraživačka pozicija usmjerena $\mathrm{k}$ ukazivanju na $\mathrm{rad} \mathrm{i}$ privatno vlasništvo kao sredstva emancipacije žena unutar specifičnih društveno-političkih okolnosti promijenjena je do srži te, iako zadržava elemente prve teze, konačni cilj rada ima sasvim drukčiju prirodu. Dakako, tijekom pripreme terena nisam bila svjesna heterogenih življenih iskustava, različitih razina znanja i sjećanja o radnicama te značajne distinkcije unutar ženskog radničkog svijeta. Domaći sam teren možda

\footnotetext{
${ }^{7}$ Postupak prepoznavanja razlike između etnografovog sebstva i vlastite kulture u koju je etnolog uronjen i angažiran osobno, profesionalno i prijateljski.
} 
shvaćala "zdravo za gotovo", uljuljkana u ideju o privilegiranom položaju uvjetovanom življenjem u istraživanoj kulturi. Proces istraživanja i sinteze rezultata trajao je nekoliko godina. Danas sam, pišući ove retke, sigurna da bi ovaj rad bio značajno osakaćen i nepotpun da tom procesu nisam dala svo ovo vrijeme. $\mathrm{S}$ istraživanjem sam rasla, otkrivala i mijenjala pozicije. Rad je u moj život uveo niz osoba koje su me učile iščitavati razgovore, koje su svojim postupcima iskustveno osnaživale moju percepciju uloge i pozicije žena radnica, koje su mi na domaćoj i međunarodnoj akademskoj razini s jedne strane ukazivale na određene nedostatke mojih promišljanja, a s druge potvrđivale važnost teme i smjer istraživanja. Insajderska pozicija zaista doprinosi razumijevanju eksplicitnih i implicitnih kulturnih pojava. To sam osvijestila u samom procesu istraživanja. Također, suživot s radnicama, mreža poznanstava, svakodnevna uronjenost $\mathrm{u}$ naoko banalne teme o vremenu $\mathrm{i}$ frizuri, sudjelovanje $\mathrm{u}$ privatnim trenucima njihova života, stvaraju korpus iskustva koji je mijenjao mene samu i moju istraživačku poziciju. Dakle, ne samo da su to elementi analize njihovih heterogenih iskustava nego ta iskustva postaju i generatori novih svjetonazora i pozicija istraživača. Njihove su me priče mijenjale kao Rovinjku i kao etnologinju.

Upravo su osobna angažiranost istraživača i nedostatak ili manjak prostorne, vremenske, emocionalne i intelektualne distance od istraživane sredine potaknuli akademsku raspravu s pitanjem jesu li to hendikepi u realizaciji objektivne prosudbe, odnosno znanstveno validnog istraživanja. S jedne strane, smatrali su pojedini zagovaratelji objektivnog pristupa istraživanju, poželjna pozicija insajdera koji razumije neizgovorene stavove svojih sugovornika istodobno postaje najveći neprijatelj znanstvenog poduhvata. Trinaest godina od svog utjecajnog rada "Insider Reserach: An Ethnography of a Debate” iz 1981. Aguilar je raspravu oko snaga i slabosti istraživanja unutar vlastite zajednice, koja se tada svela na pretpostavljeni nedostatak objektivnosti kod insajderskih istraživača i nedostatak razumijevanja o istraživanoj kulturi kod autsajderskih istraživača, okarakterizirao kao neutemeljenu jer su i insajderski i autsajderski istraživači podjednako podložni rizicima stvaranja predrasuda i problemima objektivnosti (Aguilar 1994: 97). Deset godina prije njega, ističući ih kao društveno-konstruktivističke argumente, Haraway je jasno kritizirala ideju o objektivnosti znanja koje se stiče iz "privilegirane" (najčešće marginalne) pozicije jer su 
sva znanja konstrukti u službi uspostave moći, a ne istine (Haraway 1988: 576).

Koje su onda specifičnosti i prednosti insajderske etnografije? Što karakterizira domaći teren? Postoji li neka privilegirana pozicija iz koje možemo lakše i bolje obuhvatiti i razumjeti predmet istraživanja? Na koji način istraživati na domaćem terenu?

O domaćem terenu unutar hrvatske akademske zajednice pisala je, između ostalih, Valentina Gulin Zrnić. Temeljem svojeg dugogodišnjeg istraživanja svakodnevne kulture i procesa stvaranja zajednice unutar jednog novozagrebačkog naselja, autorica je iznjedrila koncept autokulturne defamilijarizacije. Autokulturna defamilijarizacija podrazumijeva proces očuđivanja, kojim Gulin Zrnić nudi svojevrsni recept za racionalizaciju osobnih pozicija, znanja $i$ iskustva nužnog $u$ znanstvenom radu. Nasuprot empatiji, potrebnoj za razumijevanje kulture u uobičajenim terenskim okolnostima, na domaćem terenu neophodno je odmaknuti se od utvrđenih stavova i praksi te vlastitog vrijednosnog sustava (Gulin Zrnić 2005: 169-170). Autorica na temelju vlastitog domaćeg terena najprije osvještava nedostatak jednog od ključnih elemenata antropološkog terena, a to je prostorna distanca. Klasična metodološka paradigma koja implicira odvojenost terena $\mathrm{i}$ istraživanog te osobnog doma $\mathrm{i}$ akademske zajednice nije bila zadovoljena, već se u pomanjkanju te prostorne (ali i intelektualne) distance metodološka i epistemološka problematika manje koncentrirala na pitanje "ulaska na teren", a više na "izlazak iz terena", odnosno uspostavljanje potrebne distance (ibid.: 161). Takva situacija, kada je privatni život istraživača isprepleten i neodvojiv od akademskog, zahtijeva auto-antropološki pristup (ibid.: 165). Autorica je koncept auto-antropologije sagledala kroz tri istraživačke auto-reference: u odnosu na subjekt istraživanja i metodologiju (disciplina), u odnosu na vlastitu kulturu (društvo i kultura) i u odnosu na osobno (autobiografsko) iskustvo. Domaći se teren, prema tome, odmiče od klasičnog etnografskog kanona koji je predstavljen istraživanjem po osi “drugi-drugdje-drugačiji” u “drugi-ovdje-drugačiji”. Na tragu toga je Sanja Potkonjak ustvrdila da etnolog rijetko kada dolazi u situaciju u kojoj postoji istraživačka pozicija na ravni "mi-ovdje-isti” (Potkonjak 2014: 29). Možemo zaključiti da se na specifičnom primjeru istraživanja svakodnevice urbane kulture novozagrebačkog naselja Gulin Zrnić isprepliću karakteristike domaćeg terena i zahtjevi auto-antropologije, s obzirom na to 
da znanstvenica ne samo da istražuje na domaćem terenu (u svom naselju) već i dijeli simbolički prostor (sudjeluje u stvaranju zajednice) istraživanja $\mathrm{s}$ ispitanicima. Međutim, ta “čista” insajderska i auto-antropološka pozicija u praksi nije funkcionirala u potpunosti. Opisujući svoje istraživačko iskustvo unutar vlastite novozagrebačke zajednice stanara, autorica jasno ističe da se lakše "infiltrirala" u određene grupe poput grupe majki s mlađom djecom ili crkvene zajednice, dok je "ulazak na teren" grupe vlasnika pasa ili igrača boća bio zahtjevniji. Kao posljedica toga njezina "pozicija insajderice je pozicionirana, te sa svim (mojim) iskustvima rezultira samo jednom, parcijalnom istinom" (Gulin Zrnić 2005: 165). Ova konstatacija indirektno otvara pitanje suštinskog razumijevanja insajderskog/domaćeg terena.

Govoreći o terenu obično se referiramo na fizički prostor. ${ }^{8}$ Međutim, Clifford Geertz je još 1973. godine otvorio prostor promišljanja terena ne samo kao fizičke lokacije već i kao predmeta istraživanja ili bolje rečeno mjesta" istraživanja. "Lokacija istraživanja nije isto što i predmet istraživanja. Antropolozi ne istražuju sela (plemena, gradove, susjedstva...); oni istražuju u selima" (Geertz 1973: 22). Shodno tome, ako teren razumijemo kao intelektualni i emotivni prostor (mjesto), onda bismo se, govoreći o insajderskoj etnografiji i bliskom terenu, mogli i morali odnositi i na intelektualni i emotivni prostor koji dijelimo, odnosno koji ne dijelimo (autsajderska etnografija) s ispitanicima. Fokus istraživanja i promišljanja se tada premješta s geografske lokacije na lokaciju dijeljenog, zajedničkog iskustva (simboličko, identitetno). Slijedeći ovakvo razumijevanje terena, etnografija bliskoga se odmiče od paradigme Drugi-ovdjedrugačiji, koja se konstituira isključivo temeljem prostorne dimenzije etnografskog poduhvata, te se okreće negaciji dihotomije Mi-Drugi nudeći novo razumijevanje etnografije bliskog. U takvom odnosu, kada istražujemo intelektualno i emotivno "bliska" mjesta, nužnost auto-antropologije je neupitna, posebno ako je shvaćamo kao "istraživanje u kojem istraživač i istraživana grupa dijele premise o društvenom životu koje oblikuju antropološko pitanje" (Strathern 1987: 18).

\footnotetext{
${ }^{8}$ Ovdje mislim i na digitalnu antropologiju, odnosno digitalni teren (engl. digital fieldwork), koji podrazumijeva participaciju istraživača u online zajednicama u smislu promatranja $\mathrm{i}$ analiziranja njihovih navika i svjetonazora.

${ }^{9}$ Pojam mjesta koristim kao kritički antropološki koncept koji mjesto karakterizira kao društvenokulturnu konstrukciju. U tom smislu, prostor podrazumijeva fizičku dimenziju, dok je mjesto okarakterizirano identitetskom dimenzijom.
} 
Međutim, moj je "domaći” teren, gdje sam se po ustaljenom shvaćanju "bliskog" mogla identificirati kao insajder, s vremenom poprimao obilježja dalekog i stranog. Što sam više tražila sugovornike, to ih je teže bilo pronaći. S vremenom se pročulo da istražujem na temu žena radnica, znalo se s kim sam već razgovarala pa su na temelju toga (pretpostavljam zbog međusobne netrpeljivosti) neke potencijalne kazivačice odustajale od razgovora. Činjenica da sam nečija poznanica, prijateljica, unuka, kći ili sestra snažno je obilježila proces istraživanja. Dodajući na to akademski kontekst unutar kojega su me kazivačice smještale te vremensku distancu od predmeta istraživanja kao i generacijski jaz u odnosu na istraživanu zajednicu, potpuna identifikacija s domaćim terenom nije bila moguća.

O nemogućnosti poistovjećivanja s domaćom istraživanom zajednicom pisala je Jasna Čapo Žmegač na temelju istraživanja prisilnih migracija srijemskih Hrvata (v. Čapo Žmegač 2006). Autorica posebno ističe pitanje lojalnosti istraživanoj zajednici u odnosu na nužnost profesionalne etike. Lojalnost se pritom dokazuje u samom procesu zauzimanja pozicije, one advokata ili analitičara (ibid.: 215-216), te kasnije, u procesima restituiranja istraživanja (ibid.: 226-228) istraživanoj zajednici. Smatram da je "čisto" definiranje pozicije moguće samo ako etnolog-istraživač istražuje temu kojoj je privržen i za koju osjeća određenu emotivnu vezanost te joj pristupa iz aktivističke pozicije. Tada će zauzeti tzv. poziciju advokata i koristiti svoj znanstveni položaj za propagiranje određenih stavova. U svim ostalim insajdersko-istraživačkim kontekstima vjerojatnija je hibridnost spomenutih pozicija, a koja je uvjetovana identitetnom polimorfnošću etnologa (v. Narayan 1993).

Kirin Narayan u svom iznimno utjecajnom članku iz 1993. godine progovara o stereotipizaciji insajderskih (engl. native) istraživača, ${ }^{10}$ ali, što je za moj rad značajnije, uočava utjecaj koji višestruki identiteti imaju na istraživanje. Ti se identiteti susreću u konceptu bikulturalnosti objedinjavajući identitete prisutne na razini svakodnevnog

\footnotetext{
10 Važno je naglasiti da je istraživački kontekst takozvanih domaćih antropologa (engl. native anthropologists) o kojem kritički pišu Abu-Lughod (1991), Kondo (1990), Narayan (1993) i drugi sasvim drugačiji od domaćeg terena u hrvatskoj etnološkoj praksi. Istraživački kontekst o kojem pišu navedene autorice opterećen je kolonijalnim diskursom, a odnosi se prije svega na rad antropologa Trećeg svijeta unutar pretpostavljenog domaćeg geografskog konteksta. Detaljnim opisom svog zamršenog i višenacionalnog obiteljskog porijekla, Narayan ukazuje na problematiku spomenutog koncepta i pratećih implikacija.
} 
života (dob, spol, obrazovanje, nacionalnost i dr.) s pripadnošću akademskom svijetu i s ciljem koji uvjetuje specifičan etnološki susret. Osvještavajući bikulturalnost istraživača, Narayan se zalaže za utjelovljenu hibridnost koja bi kao strategija pisanja i reprezentacije umanjila posljedice bikulturalnosti (1993: 672).

U okviru mojeg istraživanja rovinjskih radnica pitanje lojalnosti se pojavilo kod suprotstavljenih stavova unutar moje vlastite obitelji, koja je bila uključena u samo istraživanje, te u vezi etničke pripadnosti radnica, odnosno mojeg odnosa prema tom “tihom” sukobu. U samom početku, kao zagovornici ženskih prava, činilo mi se lako zauzeti poziciju, čak i onu advokatsku. Međutim, slično kao u slučaju koji opisuje Čapo Žmegač (2006: 220), kada sam uvidjela da ne postoji homogeno žensko iskustvo i stav, već da se $\mathrm{u}$ određenim situacijama nazire (često implicitno iščitan) konflikt među radnicama, otvorila su se pitanja lojalnosti i odgovornosti (ibid.). Moja osobna i znanstvena odgovornost reflektiraju se u odlomcima koji slijede i vjerojatno je da će recepcija biti podijeljena. Način restitucije znanja ${ }^{11}$ nije sagledan u okvirima ovog rada.

Faktor ometanja istraživanja su očekivanja. Samonametnuta očekivanja o razini posvećenosti $\mathrm{i}$ utjelovljenosti $\mathrm{u}$ teren $\mathrm{s}$ jedne strane $\mathrm{i}$ društvena očekivanja $\mathrm{o}$ adekvatnosti reprezentacije s druge. Dorinne Kondo (1990) svoje terensko iskustvo u Japanu kao Japanoamerikanka okarakterizirala je svojevrsnom fragmentarnošću identiteta s obzirom na to da se ovisno o kontekstu susreta više ili manje naglašavalo njezino američko, odnosno japansko podrijetlo (Kondo 1990: 12). Marc Augé ističe da “je etnolog također predmet uzastopnih identifikacija (ali iz toga gledišta ništa radikalno ne razlikuje tu situaciju od one koja bi ga neposredno suočila s radikalno stranom skupinom), ovisno o poziciji koju zauzima ili koju mu pripisuju u mjestu stanovanja te isto tako ovisno o situaciji u kojoj se nalazi (ili u kojoj zamišlja da se nalazi) u cjelokupnom društvu" (Augé 2002: 30-31). Antropološki imperativ uranjanja u teren za Kondo je značio umanjivanje "američkih navika" i kulturnu resocijalizaciju primjerenu Japanu. Naglašavanje svog japanskog identiteta kako bi se što više zbližila s istraživanom zajednicom u jednom ju je trenutku dovelo do "kolapsa identiteta". Jednog dana, ona je u refleksiji mesarskog izloga u samoj sebi prepoznala Drugog (Kondo

\footnotetext{
${ }^{11}$ Osim kao javno dostupna disertacija.
} 
1990: 17). Doživjevši svojevrsnu epifaniju, Kondo je kroz vlastitu ambivalentnu istraživačku poziciju shvatila da je identitet istraživača ključni dio njegova epistemološkog uporišta. O nezavidnoj poziciji u kojoj se kao istraživač koji želi uroniti u istraživanu kulturu možemo naći govori i Jeanne Favret-Saada (2012). Da bi uopće mogla pristupiti kazivačima, autorica se iskustveno uključila u rituale vezane uz tradicijsku medicinu i vještičarenje na zapadu Francuske. Značaj Favret-Saadinog rada za moje istraživanje i pisanje sastoji se u apostrofiranju procesa, nužnosti rehabilitacije senzibiliteta, ${ }^{12}$ prihvaćanja afekta kao dijela procesa saznavanja i osnaživanja $a$ posteriori metode bilježenja terena. ${ }^{13}$ Situacija u kojoj je istraživač dugi niz godina uronjen u istraživanu zajednicu onemogućava "klasični" terenski pristup dolazakbilježenje-odlazak (i eventualno vraćanje), te je takvom terenskom kontekstu a posteriori bilježenje, sa svim posljedicama koje takav pristup dakako ima, osvježenje koje otvara mogućnost prihvaćanja raznovrsnog stjecanja znanja i iskustava, a koji u konačnici "proizvode" etnografiju.

Moj domaći teren nije blizak. On je domaći jer ga kao takvog konstituira društveno-geografska odrednica. Suživot s rovinjskim radnicama unutar zajedničkog javnog prostora olakšava iščitavanja implicitnog značenja s obzirom na to da zajedno činimo i dijelimo rovinjsku kulturu. Međutim, ta je kultura heterogena i naši pogledi na nju su heterogeni. Kulturna heterogenost uvjetovana je višestrukim identitetima svojstvenim svakom pojedincu. Upravo ta identitetska nemogućnost potpunog poistovjećivanja s istraživanom zajednicom omogućava mi odmak od terena, od bliskog Drugog. ${ }^{14}$ U zaključku da put etnologije koji na početku zagovara da isto postoji kod

\footnotetext{
12 “Općenito, moj rad stavlja u pitanje antropološki parohijalni naglasak na idealne aspekte ljudskog iskustva, na kulturološku proizvodnju razumijevanja, da se upotrijebi termin proizašao iz klasične filozofije. Čini mi se da postoji hitna potreba da se rehabilitira staromodni senzibilitet, sad čak i više jer smo bolje opremljeni da se pozabavimo time nego što su to mogli filozofi sedamnaestog stoljeća" (Favret-Saada 2012: 437).

13 "Dopustim si da to utječe na mene, bez da pokušavam proučiti što su radili, niti da razumijem i zapamtim. Kad stignem kući, napišem nekakvu kroniku ovih enigmatskih događaja (često, situacije koje se tamo dogode toliko su intenzivne da bi onemogućile ovo a posteriori zapisivanje bilježaka). Ovaj terenski dnevnik, koji je dugo vremena bio moj jedini materijal, imao je dva cilja. Prvi je bio kratkoročni: pokušati razumjeti što su htjeli od mene... Drugi cilj je više bio dugoročniji: moje bilješke su bile manično precizne, tako da bih jednog dana mogla ponovno ishalucinirati iskustvo $i$ tako ih, zato što ne bih više bila ponesena, već ponovo ponesena - konačno razumjeti” (ibid.: 240-241).

${ }_{14}$ Odlučila sam koristiti veliko slovo kod riječi Mi i Drugi kako bih naglasila bliskost i određenost koncepta. Mi označava kolege etnologe, Drugi su naši sugovornici. Kada se referiram na druge autore, način pisanja ostavljam u izvorniku.
} 
drugoga, a završava tvrdnjom koju mu nameću tereni etnologije kod kuće: “drugo postoji u istome", Augé vidi drugost koja odgovara distanci potrebnoj da bi promatranje koje nije nalik pukoj autorefleksiji uopće bilo moguće (Augé 2002: 30). Drugi u kontekstu ovog rada nije ništa/nitko drugo/i doli subjekt istraživanja s kojim ne dijelim emotivna i intelektualna mjesta. Takav odnos ne implicira a priori primjenu znanstvenog autoriteta. Suvremene zajednice, odnosno naši sugovornici, intelektualno osviješteni i osnaženi društveno-političkim i tehnološkim dostignućima također umanjuju dihotomiju Mi-Drugi. Osvještavanjem bikulturalnosti, fragmentiranosti identiteta, pitanja lojalnosti i (ne)mogućnosti autokulturne defamilijarizacije, u procesu istraživanja se oblikovala kompleksna znanstvena pozicija insajderskog autsajdera koja u metodološkom smislu zahtijeva primjenu pozicioniranog znanja (Hartsock 1983; Haraway 1988; Hekman 1997), a koje se u epistemološkom smislu konvergira prema intersekcionalizmu kao analitičkom okviru ovog istraživanja.

Pozicionirano znanje se epistemološki formira kao odgovor na pitanje objektivne spoznaje te nastaje u okviru feminističke teorije stajališta. "Duga povijest" feminističke teorije stajališta započinje 1983. godine objavom knjige Money, Sex, Power u kojoj Nancy Hartsock marksistički koncept saznavanja sa stajališta proletarijata prilagođava feminističkoj teoriji. Ideja teorije stajališta utemeljena je u uvjerenju da je poimanje zbilje i međusobnih društvenih odnosa u kapitalističkom društvu jedino moguće iz pozicije marginalnih skupina koje su zbog svoje podređene pozicije sposobnije jasnije i sveobuhvatnije sagledati društvene odnose (Hartsock 1983: 116). Uz kritiku nejasne artikulacije rodne perspektive klasnog sustava, Hartosck prilagođava marksistički model teorije stajališta ženskom iskustvu, utemeljivši tako teoriju feminističkog stajališta (v. ibid.: 231-240). Cilj i karakteristika takve teorije sažeti su u prvim redcima jedanaestog poglavlja knjige: "Predlažem da, kao što je slučaj sa življenim iskustvom/životom proletarijata u marksističkoj teoriji, tako i iskustva žena omoguće partikularni pogled na mušku nadmoć kao i stajalište koje će biti temelj kritike falokratičnih institucija koje konstituiraju kapitalistički patrijarhat" (ibid.: 231). Slijedeći ovu logiku, etnolozi, antropolozi, ali i sociolozi, kako je vidljivo i iz primjera u nastavku teksta, koriste teoriju stajališta kao metodu "promišljanja i istraživanja iskustava pozicijâ različitih drugih u društvu, nasuprot dominantnim i hegemonijskim 
skupinama, temama ili pristupima. S obzirom na to može li se njome problematizirati pozicija bilo koje skupine koja je teorijski i istraživački podzastupljena, ovaj pristup ima potencijal za afirmaciju iskustva etničkih, rasnih i rodnih manjina, kao i sjecišta svih navedenih identiteta i praksi" (Barada 2013: 200). Koristim navedeni citat kako bih artikulirala primjenu teorije stajališta unutar metodološkog okvira i kako bih navela na daljnje promišljanje pojma sjecišta, a kojem ćemo se vratiti kasnije. Prvi dio navoda, koji naglašava istraživački potencijal marginaliziranih skupina, podložan je kritici kao što je to bila i feministička teorija stajališta kasnih 1980-ih. Naime, unatoč snažnom doprinosu feminističkoj teoriji i razvoju epistemologije uopće, feministička teorija stajališta je u narednim godinama, pa i desetljećima, doživjela brojne kritike. Posebno je značajna kritika usmjerena na propagiranu povlaštenu poziciju određenih skupina (marginalizirane grupe: žene, radnička klasa, rasne ili nacionalne manjine i dr.) u odnosu na dominantne strukture. Hartsock inzistira da će vladajuća grupa svoju perspektivu doživljavati kao jedinu ispravnu, umanjujući validnost drugih. Također, percepciju realnosti vladajuće klase smatra djelomičnom i iskrivljenom, dok onu podčinjenih grupa vidi kao "istinsku" sliku odnosa među zajednicama te je u tom smislu i dovodi u vezu s oslobodilačkim potencijalom same teorije (v. Hekman 1997: 343). Izvorna formulacija feminističke teorije stajališta počiva, dakle, na dvije pretpostavke; da je svako znanje "smješteno", te da je jedna pozicija (u našem slučaju ona ženska) u prednosti, s obzirom na to da zbog svog "privilegiranog" položaja omogućava otkrivanje društvene zbilje. Dekonstrukcija druge pretpostavke, tumači Hekman, implicitna je prvoj, stoga je promišljanjem i razvojem teorije problematična priroda druge pretpostavke uskoro došla na čelo feminističke rasprave (ibid.: 349). Pod utjecajem postmodernističkih shvaćanja različitosti, feministkinje su napustile dugo promoviranu homogenost ženskog iskustva, što je, dakako, snažno utjecalo na nužnost preispitivanja koncepta teorije stajališta. Prihvativši različitost žena kao danost, uz činjenicu da žene zauzimaju različite pozicije u društvu, teorija stajališta se morala sagledati iz novog rakursa. Pritom, bilo kakvo preferirano pozicioniranje jednako je s jedne strane relativizaciji, a s druge jednoumlju znanstvenih autoriteta. Kao alternativu relativizaciji znanja s kojom bi se "teorija stajališta" mogla dovesti u vezu, Haraway nudi parcijalna, locirana i kritička znanja koja podržavaju mogućnost stvaranja mreže odnosa. Haraway inspirativno zaključuje da u mogućnosti lokalizacije čuči pitanje 
ranjivosti zato što se feministička objektivnost opire simplifikaciji i fiksaciji i što je "nezasitno znatiželjna otkrivati mrežu različitih pozicioniranja" (Haraway 1988: 584). Teoriju pozicioniranog znanja sagledavam, dakle, iz dvije pozicije; smještanja sebe kao žene znanstvenice i osvještavanja vlastitog pozicioniranog znanja, te šire epistemološki slijedeći suvremenu feminističku misao koja prihvaća revidiranu feminističku teorija stajališta u dijelu "koji afirmira heterogenost ženskog iskustva i činjenicu da je svaki pokušaj saznavanja društveno pozicioniran” (v. https://www.iep.utm.edu/fem-stan/). ${ }^{15}$

U svom članku iz 2013. godine "Primjena feminističke teorije stajališta u istraživanju ženskih profesionalnih biografija" Valerija Barada napominje oslobodilački potencijal (feminističke) teorije stajališta, ali se poput mnogih feministkinja koje zastupaju teoriju stajališta upliće u mrežu epistemološke prednosti. Izuzevši to, Barada opravdano napominje da ovaj pristup ima potencijal za afirmaciju sjecišta svih navedenih identiteta (etničkih, rasnih i rodnih manjina) i praksi (Barada 2013: 200). Razumijevanje sjecišta identiteta, prema teoriji intersekcionalizma, a koja će se u ovom radu koristiti kao analitički okvir heterogenih radničkih iskustava, osnažuje istraživačku poziciju koja negira mogućnost epistemološke prednosti te zagovara sagledavanje neočekivanih mreža odnosa moći unutar deklarativno i tek naočigled homogenih istraživanih grupa.

\section{2. Dizajniranje istraživanja}

Terenski rad je bio i ostaje definirajuća odrednica antropološke discipline (Rabinow 1977: 1).

Moje istraživanje položaja i uloga rovinjskih industrijskih radnica započelo je 2009. godine. Promišljanje i definiranje teme nastupilo je netom prije upisa doktorskog studija, a razvijalo se u kontekstu mog radnog mjesta. Odabir teme reflektira stoga moje osobne afinitete, ali i potrebe Etnografskog muzeja Istre-Museo etnografico dell'Istria (EMI-MEI), u sklopu kojeg sam provodila istraživanje. Budući da se dotad nitko unutar

\footnotetext{
${ }^{15}$ Mrežnoj stranici pristupljeno 2. 11. 2019.
} 
Muzeja, ali i šire nije sustavno bavio ženskim pitanjem na području Istre iz etnografskog rakursa, interes za ovakvim poduhvatom bio je obostran. Dakako, dodatna vrijednost istraživanja je specifičnost područja ženske djelatnosti koje je za temu odabrano, a to je industrijski rad unutar urbanog istarskog konteksta. Ne treba posebno naglašavati kako su se sve do kasnih 1990-ih, kada se pod novim vodstvom EMI-MEI otvara k suvremenosti i svakodnevici, etnografska istraživanja temeljila na proučavanju tradicijske materijalne kulture zastupljene kroz muzejske zbirke, a koje reflektiraju posebne politike sakupljanja uvjetovane društveno-političkim kontekstima unutar kojih nastaju i koje su uglavnom usmjerene na ruralne zajednice promatrane kao ahistorični entitet. Tematsku iznimku, a vezano za ovaj rad, čine istraživanje rudarstva koje provode dr. sc. Ivona Orlić (u muzeološkom kontekstu) ${ }^{16}$ i dr. sc. Andrea Matošević (2011) (u širem antropološkom kontekstu, ali izvan muzejske institucije) te rad dr. sc. Tanje Kocković Zaborski, koja tematizira život Šavrinka ${ }^{17}$ za potrebe novog stalnog postava Etnografskog muzeja Istre. Moj se rad od samog početka tematski i metodološki kretao unutar granica feminističke i industrijske antropologije. Važno je pritom naglasiti da je Etnografski muzej Istre-Museo etnografico dell'Istria kao jedina institucija s etnografskim predznakom u Istri svoju misiju, koliko je god bilo moguće, uvijek temeljio na širem znanstvenom etnološkom radu koji je nadopunjavao onaj muzeološki.

Po odabiru teme uslijedili su razrada plana istraživanja i definiranje istraživačkih pitanja. Krenula sam od propitivanja vlastitih znanja, sjećanja i stavova o rovinjskim radnicama. Moja prva sjećanja koja se tiču Tvornice duhana Rovinj vezana su uz povremenu pojavu mrlja u moru ispred same tvornice i miris duhana koji se širio u neposrednoj okolini. Tek su se drugim pokušajem prisjećanja javljale slike o lijepo odjevenim djevojkama fotografiranima ispred TDR-a krajem 19. stoljeća. Čini mi se kako su upravo njihova brojnost i fotografska elegancija na mene ostavile najsnažniji dojam. Fotografije sam imala prilike gledati gotovo svakodnevno u ugostiteljskom objektu Tabacheina, koji se nalazio tik do tvorničkog pogona gdje smo, okruženi starim fotografijama, provodili bezbrižne srednjoškolske i studentske ljetne odmore. Radom na

\footnotetext{
${ }^{16}$ Novi stalni postav EMI-MEI.

${ }^{17}$ Novi stalni postav EMI-MEI.
} 
doktorskoj disertaciji željela sam istražiti što se krije iza tih elegantnih tijela i bezizražajnih lica.

U skladu s "mitom” o tabacchinama (naziv za radnice Tvornice duhana Rovinj, ali i drugih duhanskih pogona u talijanskom govornom području) kao bogatim i emancipiranim ženama, istraživački se problem fokusirao na sagledavanje pretpostavljene privilegirane pozicije radnica u odnosu na muškarce, koji su tada uglavnom bili ribari i poljoprivrednici. Takva bi situacija zaista predstavljala iznimku u svemu što sam dotad čitala i znala o poziciji žena kroz povijest, ali i u suvremenom okruženju, pa bi dokazivanje emancipacijskog potencijala industrijskog rada i svojevrsna nadmoć žena svakako bacili novo svjetlo na žensko pitanje. Pretpostavljala sam, također, da su za takav njihov status zaslužne specifične društveno-povijesne i političke okolnosti. Valjalo je stoga ispitati povijesne silnice koje su oblikovale plodno tlo za razvoj ženske emancipacije. Prvi je impuls bio provesti što je moguće više intervjua s radnicama ili osobama koje se sjećaju radnih dana svojih majki, baka, pa čak i prabaka. Kvalitativno terensko istraživanje polustrukturiranim intervjuom nametnulo se kao temeljna tehnika istraživanja, prije svega zbog mojih vlastitih istraživačkih afiniteta, a zatim i zbog uobičajene etnološke prakse te činjenice da sam određena znanja o tabacchinama usvojila odrastanjem u Rovinju, što je potencijalno značilo da ću kao "insajderica” lako doći do kazivanja. Nemogućnost promatranja ženskog rada s obzirom na vremenski raspon koji sam odlučila tretirati, vjerujući u rani razvoj emancipacije kroz industrijski rad, umanjila je mogućnost korištenja metode promatranja sa sudjelovanjem. Ona se ipak pokazala nužnom, ne kako bih promatrala ženski rad i njihovu svakodnevicu u kontekstu industrijskog rada, već svakodnevni život kazivačica, međusobne odnose nekadašnjih radnica i društvenog sjećanja na radnice, ali i, što je najvažnije, odnos promatračice (mene same) i promatranih. Intervjuima je prethodilo kabinetsko istraživanje dostupne literature. Željela sam provjeriti opće informacije o uvjetima rada (sati rada, visina plaće, odmor), statističke podatke o odnosu broja žena i muškaraca zaposlenih u industrijskim pogonima, dob radnica u trenutku zapošljavanja i slično. Također, željela sam ovladati terminologijom koja bi mi potencijalno trebala u razgovoru s radnicama. Godinama sam slušala o stolovima, a kasnije traci za kojom su radnice radile, ali nisam znala gotovo ništa o 
tehnološkom procesu obrade duhana. Iz iščitavanja dostupnih izvora o ekonomskoj povijesti Rovinja otvarala su se pitanja koja su postavljena kao temelj upitnika. Osim toga, provela sam preliminarno istraživanje literature na temu žena radnica, kao i feminističke teorije uopće. Većinu informacija, konkretno o tabacchinama pronašla sam u radovima povjesničara i kroničara rovinjske svakodnevice Bernarda Benussija (2004 [1888]), o čijim ću radovima govoriti u narednim redcima, zatim u tvorničkim časopisima TDR-a, u istraživanjima rovinjske ekonomske povijesti Marina Budicina (1997) te u knjizi Duhanski put u Rovinj Krešimira Džebe (1987). Osim nekoliko podataka koji bi bacili dodatno svjetlo na položaj radnica, informacije su se uglavnom svodile na opće podatke društvene povijesti Rovinja, arhitektonsko dostignuće koje se ogledalo u austrijskom projektu tvornice, tehnološkim procesima i brandovima cigareta. Čitanjem prvih informacija o radnicama Tvornice duhana Rovinj osvijestila sam činjenicu da su društveno sjećanje $\mathrm{i}$ folklorna građa o tabacchinama, posebno ona $\mathrm{u}$ vidu tradicijskih pjesama, prisutniji negoli pisani povijesni izvori o njima. Tu je situaciju donekle promijenio rad povjesničarke Glorije Nemec, objavljen tri godine od početka mog istraživanja, dakle 2012. godine. Nemec tretira poslijeratni period Istre iz pozicije talijanske nacionalne manjine. Istraživanje uključuje osobe koje su emigrirale u Italiju i rimaste, dakle one koji su ostali u Istri. Iako se rad kreće unutar uže epistemološko-metodološke perspektive od one moje, minucioznim navođenjem kazivanja, između ostalog i o iskustvima radničke klase, istraživanje Glorije Nemec predstavlja izvanredan izvor za razumijevanje poslijeratnih društveno-ekonomskih prilika iz pozicije autohtonog stanovišta koje se tada suočava s teškim promjenama. Tadašnje društveno-političke okolnosti reflektiraju se dakako i na industriju, ne samo na razini organizacijsko-pravnih aspekata već i kroz intersubjektivne radničke odnose.

Uz iščitavanje literature, $u$ procesu dizajniranja istraživanja provela sam i preliminarne intervjue s nekoliko poznanica. Među njima se našla i moja nonna (baka). Od nje sam željela saznati više o radu prabake Domeniche Giuricin (njezine svekrve) koja je radila u TDR-u. Razgovorom su se otvorili novi vidici i potreba za uključivanjem još jednog industrijskog pogona u istraživanje, onog za preradu ribe. Naime, Tvornica za preradu ribe Mirna, ranije Ampelea, također je zapošljavala veliki broj ženske radne snage, ali su se, prema kazivanjima, u Mirni pretežito zapošljavale 
žene slavenskog podrijetla, pridošlice u Rovinj. Nonna Maria je radila u Mirni. Temeljem osnovnih informacija o Tvornici duhana Rovinj i Tvornici za preradu ribe Ampelea, kasnije Mirna, te nagovještaja nacionalne distinkcije u kadroviranju, dizajnirala sam istraživanje koje se sastojalo od dvadeset jednog pitanja ili problemskog čvorišta. Iako sam zadržala tezu o privilegiranom položaju radnica, fokus istraživanja se okrenuo k problematiziranju heterogenosti radničkih iskustava, konkretno propitivanju odnosa moći i solidarnosti, a pretpostavljenu sam privilegiranost suprotstavila pretpostavljenoj opresiji. Budući da me već sam proces dizajniranja istraživanja doveo do novih saznanja i "promjene kursa", vrijedno je napomenuti da su "promjene fokusa u istraživačkom problemu/temi legitiman način konstrukcije istraživanja u etnologiji. Iako još nismo ni blizu terena, stalna retrospektivnost etnografskog istraživanja, čak i u fazi pripreme, obilježje je koje ne možemo zaobići” (Potkonjak 2014: 42).

U fazi pripreme definirala sam, dakle, temu, osnovni problem i glavne metode istraživanja. Metode uključuju kvalitativnu metodu polustrukturiranog intervjua i promatranje sa sudjelovanjem kao ključne metode terenskog istraživanja, zatim povijesnu metodu (kritičku analizu sakupljenih izvora) i konačno metodu ankete. Metoda ankete uključena je u posljednjoj fazi istraživanja, a kako bih što jasnije artikulirala sjećanja i asocijacije mojih suvremenika na rovinjske radnice.

Izazovi s kojima sam se susrela u dizajniranju istraživanja uključuju nesigurnost vlastite istraživačke pozicije, o kojoj je bila riječ u prvom dijelu ovog poglavlja, nedovoljnu zastupljenost literature na temu ženskog industrijskog rada u Istri i Hrvatskoj općenito te konkretiziranje istraživačkog problema, odnosno promjenu fokusa tijekom pripremne faze. Paralelno s iščitavanjem literature gradila se teorijska podloga na kojoj ću temeljiti analizu. Važno je naglasiti da naša osobnost snažno određuje i naš istraživački karakter, te sam i prije iščitavanja radova Donne Haraway intuitivno težila pozicioniranom znanju, i prije prvih konzultacija s mentoricom dr. sc. Teom Škokić "znala" da je intersekcionalizam sito kroz koje ću najvalidnije ukazati na višeznačne uloge i heterogena iskustva radnica. Najveći utjecaj na formiranje rada imala je feministička antropologija sa svim svojim razvojnim putanjama iz kojih sam vukla inspiraciju za teorijske i metodološke pravce, jer feminizam ne podrazumijeva jedan 
pravac i ne nudi jednu epistemologiju, odnosno metodologiju; feminizam je specifičan način bivanja u sadašnjosti iz kojeg promatramo prošlost i pokušavamo utjecati na budućnost. Svaka "feministička sadašnjost” drugačije gleda na povijest i drugačije gradi budućnost. Povijesna metoda primijenjena u ovom radu također je "inficirana" postmodernističkim antropološkim dosezima, stoga je povijesna metoda istraživanja implementirana iz rakursa nove kulturne historiografije (v. Gross 2006: 595) i feminističke historije (v. Gross 1993: 56-57). Mislim da su to jedina prirodna povijesna očišta ovog rada.

\section{3. Kvalitativno etnografsko istraživanje polustrukturiranim intervjuom}

Polustrukturirani upitnik za intervjue ${ }^{18}$ dizajniran je tijekom višegodišnjeg promatranja konstrukcije i eksploatacije ženskog radničkog identiteta u javnom rovinjskom prostoru (brandiranje), razgovora s članovima obitelji bivših radnica $\mathrm{u}$ navedenim industrijama, iščitavanja tvorničkih časopisa i analize knjige zaposlenih. Svako od dvadeset i jednog pitanja, odnosno problemskih čvorišta koja su činila temelj intervjua, imalo je potpitanja. Ista su se koristila i prilagođavala ovisno o tijeku razgovora. Pitanja su izvorno nastala na talijanskom jeziku jer sam očekivala da ću prvenstveno razgovarati s pripadnicama talijanske manjine, ali sam ih kasnije spontano prilagođavala kazivaču, ovisno o tome na kojem se jeziku lakše izražava. Nije neuobičajeno da se i pripadnice slavenskog, hrvatskog stanovništva ponekad spontano služe talijanskim jezikom s obzirom na to da su školu završavale na talijanskom jeziku ili su se udavale za Rovinjce (autohtono romansko stanovništvo) i da su većinu života provele u Rovinju.

Intervjue sam najprije provela među poznatim osobama. Dvije su ključne žene zaslužne za bogate opise radnih uvjeta, ali prije svega niza svakodnevnih situacija koje su obilježile njihove živote; moja nonna i tetka Delia. S njima sam provodila sate i sate u razgovorima, vraćala se po objašnjenja i tumačenja određenih nejasnoća, a one su me pratile, vrlo često i nesvjesno, s pokojim novim podatkom, fotografijom, dostupnom

\footnotetext{
${ }^{18}$ Intervju/polustrukturirani - interpersonalna, dijaloška situacija dviju ili više osoba u kojoj se raspravlja o nekoj temi; polustrukturirani intervju je tematski vođen intervju s otvorenim pitanjima koja ne sugeriraju odgovor niti očekuju jednoznačni odgovor (Potkonjak 2014: 95).
} 
kazivačicom. Dalje se uzorkovanje provelo slijedeći metodu snježne grude "koja se temelji na ciljanome odabiru uskoga kruga ljudi koji zatim šire uzorak, upućujući istraživača na druge osobe koje bi mogao ispitati". ${ }^{19}$ Sugovornice sam nalazila među njihovim poznanicima, a kada smo iscrpile moguće izvore, kontaktirala sam Dom za odrasle "Domenico Pergolis" čije su štićenice bile iznimno kolaborativne i s kojima sam provela vrijedne trenutke. U razgovoru s članovima Zajednice Talijana "Pino Budicin" osvijestila sam činjenicu o emigraciji brojnih talijanskih radnica nakon 1947. godine, koje su u Italiji nalazile zaposlenje upravo zahvaljujući fami o vrijednim rovinjskim radnicama. Svi su me ti susreti obogatili informacijama nužnim za pisanje rada, no mnogi su me snažno potresli na osobnoj razini, te tako u više navrata osnaživali kao ženu i etnologinju, dajući smisao cjelokupnom etnološkom poduhvatu.

Ukupno sam intervjuirala 19 osoba, 17 žena i 2 muškarca. Najstarija kazivačica rođena je 1920. godine, a najmlađa 1954. godine. Sedam žena je govorilo isključivo o svom iskustvu, dok su ostali kazivači uz svoje radno iskustvo, vrlo često nevezano uz ono tvorničko, spominjali sjećanje na uvjete rada svojih majki i baka. Kod radnica rovinjskog (talijanskog) podrijetla uočen je generacijski kontinuitet u industrijskom radu, dok su intervjuirane žene slavenskog podrijetla iz okolnih sela u Rovinj dolazile same, bez prethodnika u tvornicama. Iako bi se iz potonjega moglo zaključiti da su djevojke slavenskog podrijetla dolazile u Rovinj u kasnijem periodu te da prije kasnih 1940-ih godina nisu činile dio rovinjske radne snage, povijesni izvori negiraju takvu mogućnost i ukazuju na dinamične društvene procese i ranije. Konkretno, vezano uz predmet ovog rada, u Knjizi vjenčanih iz 1906. godine jasno se vidi podrijetlo i zanimanje nevjesta. Jesu li djevojke u ranim danima industrijskog razvoja dolazile isključivo zbog posla u TDR-u ili je zaposlenje posljedica udaje, odnosno preseljenja u Rovinj, teško je reći. Činjenica da brojne prijavljene radnica iz Rovinja u prvom valu zapošljavanja nisu dobile posao u TDR-u jasno ukazuje na višak radne snage i veliki interes za zaposlenjem. Slijedeći tu logiku, možemo zaključiti da uvoz radne snage nije bio potreban, posebno ako uzmemo u obzir da je osnutku Tvornice kumovalo pismo gradonačelnika Campitellija u kojem spominje brojnu raspoloživu žensku radnu snagu u Rovinju koja ne može na drugi način steći osnovna sredstva za život (2004 [1888]: 11).

\footnotetext{
${ }^{19} \mathrm{http}: / /$ struna.ihjj.hr/naziv/metoda-snjezne-grude/20469/\#naziv, pristup 10. 10. 2019.
} 
Priključimo li, dakle, sve sudbine žena kojih smo se kroz naše razgovore dotakli, istraživanjem je obuhvaćeno 25 radničkih priča. Dostupni kazivači i sakupljena svjedočanstva o životima rovinjskih radnica uvjetovali su tako dvosmjeran razvoj rada:

1. bilježenje i interpretaciju življenih iskustava,

2. bilježenje i interpretaciju sjećanja na radnice.

Iskazi su u radu predstavljeni početnim slovima imena i prezimena kazivača, a ovdje donosim popis, koji osim inicijala sadrži i godinu rođenja.

1. A. D. Q., 1947.

2. F. Q., 1939.

3. M. G., 1934.

4. L. M., 1928.

5. M. R., 1943.

6. S. R., 1942.

7. A. R., 1942.

8. M. C., 1934.

9. A. C., 1941.

10. L. C., 1924.

11. T. L. (god. rođenja nepoznata)

12. A. D., 1929.

13. A. S., 1935.

14. D. C., 1953. 
15. S.V., 1938.

16. M. J., 1935.

17. A. С̆., 1931.

18. M. A. P., 1935.

19. M. M., 1929.

Kako je uobičajeno za kvalitativnu etnografsku metodu istraživanja polustrukturiranim intervjuom, razgovor je ponekad bilo moguće voditi tek oko nekoliko pitanja, a u drugim slučajevima bi daleko premašio osnovnu nit upitnika pa bih s kazivačima razgovarala o najrazličitijim stvarima: ponajviše bolestima, obiteljskim problemima i penziji. Osim s kazivačima, u užem smislu riječi, u desetogodišnjem procesu istraživanja ( $u$ diskontinuitetu) upuštala sam se u dijalog na temu radnica $s$ prijateljima i poznanicima. Nakon tih neformalnih razgovora također sam vodila tekstualne i audio bilješke. Osluškujući suvremene probleme i uspjehe Mirne i TDR-a pokušavala sam uvijek vidjeti radnicu i radnika iza dnevnih ekonomskih novosti. Stalno bivanje uz priče o ovim tvorničkim pogonima i njihovim radnicima, koje i danas imaju ambivalentnu društvenu recepciju, otežavalo je izlazak s terena i prelazak na drugi korak rada.

\section{4. Promatranje sa sudjelovanjem}

I dok sam pokušavao ustanoviti kako promatrati i sudjelovati, zbunjenost je sve više rasla (Rabinow 1977: 96).

Metodu promatranja sa sudjelovanjem proslavio je Bronislaw Malinowski u svojem djelu Argonauti Zapadnog Pacifika ${ }^{20}$ 1920-ih godina. Sto godina kasnije, promatranje sa sudjelovanjem, uz polustrukturirani intervju, čini temeljnu etnološku metodu terenskog istraživanja. Istu su tijekom 20. stoljeća preuzele brojne druge

\footnotetext{
${ }^{20}$ Knjiga je prvi put objavljena 1922. godine, no recepcija je trajala duže i s različitim odjekom.
} 
znanstvene discipline, no, prema Perli Tadej, ova metoda predstavlja jednu od najstarijih i najuniverzalnijih metoda koje se primjenjuju u znanosti uopće (Tadej 1983: 81). Kako će Tadej reći, "za promatranje je dovoljan čovjek i njegova želja za spoznajom" (ibid.: 82). Slijedom toga, ono što razlikuje antropologiju, a naknadno i sociologiju, od sveopćeg znanstvenog promatranja jest koncept sudjelovanja. Tadej sudjelovanje objašnjava kao prisustvo istraživača na terenu $\mathrm{s}$ reperkusijama na istraživanu skupinu, odnosno razvoj novih međuljudskih dinamika. "Čisti promatrač” je samo idealna kategorija (ibid.: 81), svaki kontakt neupitno mijenja način ponašanja, stvarajući nove međuodnose. Te promjene ponašanja kod istraživanih mogu biti veće ili manje, eksplicitne ili implicitne i kao takve one same puno govore o njima. Iako je točno da prisustvo istraživača na terenu utječe na istraživanu skupinu, jednako je ispravno reći da terenske dinamike utječu na istraživača, mijenjajući često i njegove stavove. Pojednostavljenim razumijevanjem koncepta sudjelovanja u kojemu se znanstvena metoda promatranja sa sudjelovanjem izjednačava s prisutnošću istraživača na terenu ne može se dostatno obuhvatiti kompleksnost metode kvalitativnog terenskog istraživanja.

Kao kontrapunkt Tadejinu, istraživanje Jeanne Favret-Saada među francuskim narodnim liječnicama u drugoj polovini 20. stoljeća predlaže nam dekonstrukciju zbunjujuće udobnosti metodologije promatranja sa sudjelovanjem (Favret-Saada 2012: 437). Metodu promatranja sa sudjelovanjem kako je dotad prakticirana autorica opisuje kao bivanje izvan terena (promatranje) uz istovremeno zamišljanje potpune uronjenosti i prisutnosti na terenu (sudjelovanje). Kompleksnost primjene ove metode Favret-Saada je opisala slikovito: "promatranje sa sudjelovanjem u retorici se naziva oksimoronom: promatrati dok sudjeluješ ili sudjelovati dok promatraš - ovo je logično kao da jedeš zapaljeni, vrući sladoled" (ibid.). Smatrajući da tadašnjim antropolozima (koji koriste promatranje sa sudjelovanjem) nije važno sudjelovanje, već promatranje, Jeanne FavretSaada je odabrala aktivnu participaciju kao instrument stjecanja znanja (ibid.: 437-440). Govorimo, dakle, o dva različita shvaćanja koncepta sudjelovanja, a koji direktno utječu na način provođenja terenskog istraživanja te $u$ konačnici na rezultate istraživanja:

1. sudjelovanje je formulirano i shvaćeno kao prisustvo istraživača na terenu,

2. aktivno sudjelovanje u praksama/svakodnevici istraživane zajednice. 
Navedena druga opcija u sociologiji se naziva sociološki eksperiment (Tadej 1983: 83). Ako se vratimo na same začetke kulturnoantropološke discipline, bit će jasnije zašto se sve do sredine 20 stoljeća, a kod nas i kasnije, čin sudjelovanja iz sintagme "promatranje sa sudjelovanjem" dešavao sa strane, "neprimjetno", omogućavajući da se isto tumači kao puko bivanje istraživača na terenu. Dotad se objektivnost znanstvenika i njegovih metoda nije propitivala, a postizala se činom odlaska na teren, izvještavanjem s terena posredstvom detaljnih opisa mjesta i događaja, korištenjem fotografije, a kasnije i filma. Antropolozi preuzimaju ulogu medijatora koji svojim autoritativnim "glasom" postaju zamjena za osobno terensko iskustvo i, što je važnije, u znanstvenom diskursu, samim bivanjem na terenu dokazuju navodnu objektivnost vlastitog istraživanja (v. Rabinow 1986: 244). Tek je postmodernistička kritika "nevine kamere" i "autoritativnih antropoloških glasova" omogućila razvoj participativnih metoda istraživanja. O stupnju i načinu participacije odlučuje sam istraživač, odnosno njegova osobnost. U tom kontekstu, Tadej zaključuje da "njegova [istraživačeva] ličnost dolazi u 'pravi plan', budući da je stav koji će članovi promatrane grupe zauzeti prema istraživačkom radu uvelike određen stavom koji su zauzeli prema istraživaču. Za uspješno provođenje istraživanja mnogo je značajnija sama osoba istraživača, njegova snalažljivost na terenu te njegova 'sociološka intuitivnost' nego teorijsko znanje o tehnikama istraživanja" (Tadej 1983: 81). Iako je za vjerovati kako je osoba istraživača bila itekako ključna i u ranijim fazama primjene metode promatranja sa sudjelovanjem, ideju istraživačeve osobnosti lakše je uočiti i smjestiti u kontekstu njegove aktivne participacije. Osim navedenog francuskog primjera Jeanne FavretSaada, gdje je aktivno sudjelovanje dio istraživačke strategije usmjeren na eksploraciju autorske osobnosti i pronalaženja vlastite pozicije u procesima terenskog istraživanja, aktivna participacija vrlo često upućuje na "sudjelovanje" kao dio antropološkoaktivističke paradigme. Antropološkim aktivizmom kroz terenski rad, a prvenstveno metodom promatranja sa sudjelovanjem, antropolog i svećenik Ricardo Falla zagovara prava ruralne zajednice u Guatemali, odnosno skupine koja se pod političkim pritiskom, preživjevši masakr tijekom 1980-ih godina, povukla u džunglu odakle djeluje okupljena oko pokreta Zajednica naroda u otporu (Communitiy of Population in Resistance) (Manz 1995). 
Pitanje koje se postavlja jest: nije li svako antropološko istraživanje i pisanje usmjereno na ukazivanje nejednakosti, svojevrsni aktivizam? Valja se složiti s Perlom Tadej da metodom upravlja osobnost istraživača, a ne obrnuto. "Feministička se antropologija od početka imenuje politički svjesnom antropologijom, odnosno, onom koja ne prikriva činjenicu da u naše istraživanje unosimo vrijednosne sudove svojstvene našoj sredini, kao i odnose moći” (Škokić 2001: 16). Navedeni, ekstremni primjeri shvaćanja i prakticiranja metode promatranja sa sudjelovanjem, tijekom istraživačke faze, a kasnije i kroz sam čin pisanja, naveli su me na dublje promišljanje načina na koji sam koristila ovu metodu. Metoda promatranja sa sudjelovanjem "ušla” je u ovaj rad tek po osvještavanju da ono što spontano radim jest "promatranje sa sudjelovanjem". Naime, vremenski raspon koji sam radom obuhvatila nije dozvoljavao promatranje radnica $\mathrm{i}$ njihovih intersubjektivnih odnosa te, shodno tome, $\mathrm{u}$ ranoj fazi planiranja istraživanja nisam uključila promatranje sa sudjelovanjem kao moguću metodu. Međutim, metodu sam spontano primijenila u promatranju konteksta istraživanja $i$ današnje percepcije industrijskih radnica. Osim toga, promatranje sa sudjelovanjem mi je, slično Favret-Saadinu iskustvu, pomoglo u vlastitom samoodređenju. Promatrala sam kako se kazivači odnose prema meni, osvještavala nevidljivu mrežu očekivanja, koristeći metodu kao strategiju navigacije u bespućima terenskog istraživanja.

Čini se da je metoda promatranja sa sudjelovanjem inherentna etnologu. Je li tome tako jer smo educirani promatrati oko sebe, osvještavati mrežu suodnosa $\mathrm{i}$ analizirati ih ili je to specifična osobina koja nas vodi najprije $\mathrm{k}$ studiju etnologije, a kasnije i kroz terenska iskustva? U svom utjecajnom djelu Reflections on Fieldwork in Morocco (1977) Paul Rabinow se s pravom pita, ako je promatranje sa sudjelovanjem toliko važno $u$ antropologiji, zašto se prirodi i iskustvu terena eksplicitno pridaje toliko malo pažnje i, što je važnije, na koji način teren pridonosi praksi kritičkog mišljenja (Rabinow 1977: 49-54). Dva su moguća zaključka relevantna za moj rad, jedan inspiriran Lévi-Straussovim Tužnim tropima ${ }^{21}$ (2011 [1955]) i Rabinowljevim

\footnotetext{
21 "Filozof koji je nekad napisao Kastinski sistem u Indiji a da se ni u jednom trenutku nije zapitao ne bi li bilo bolje da najprije tamo ode i nešto vidi vlastitim očima ('u bujici događaja samo institucije ostaju na površini', izjavio je oholo u svom predgovoru iz 1927.) nije ni pomislio da bi kvalifikacija 'urođenik' mogla utjecati na etnografsko istraživanje" (Lévi Strauss 2011 [1955]: 44).
} 
Reflections on Fieldwork in Morocco (1977), a drugi Faavret-Saadinim Being Affected (2012):

1. terenski rad koji neminovno uključuje promatranje sa sudjelovanjem apostrofira važnost i nužnost iskustva koje doprinosi obuhvatnijem i dubljem shvaćanju istraživanog te adekvatnijoj produkciji znanja,

2. metoda promatranja sa sudjelovanjem, osim uočavanja intersubjektivnih odnosa, snažno doprinosi vlastitoj autoreferencijalnosti.

Temeljem navedenih zaključaka, promatranje sa sudjelovanjem se u ovom radu okreće fenomenologiji kao pristupu čije postulate kroz metodu primjenjujem. Iako fenomenologija prati lingvistički obrat ključan za razumijevanje procesa konstruiranja kulture diskursom i odnosima moći, u promišljanju pristupa terenu odlazi korak dalje i zahtijeva osvještavanje praktične i osjetilne strane promatrane situacije (Škrbić Alempijević, Potkonjak i Rubić 2016: 13-14). “[T]jelesno i diskurzivno ne treba promatrati kao dva pola istraživačke dihotomije: te su kategorije međusobno isprepletene, pri čemu se i diskurzivna analiza itekako bavi tjelesnim praksama" (ibid.: 15). Osim toga, Sandra Harding upućuje na nužnost primjene fenomenologije u artikuliranju kritike androcentričnih postulata znanstvene metodologije. Feministkinje ističu kako su tradicionalne metode istraživanja konstruirane na način da otežavaju razumijevanje ženskog sudjelovanja u društvu. Primjenom fenomenologije možemo lakše shvatiti žensku svakodnevicu (Harding 1987: 3). Kako ćemo vidjeti kasnije u radu, tjelesnost je itekako važan segment radničkih iskustava, ne samo kao eksplicitni izričaj ili gesta tijekom promatranja i sudjelovanja u terenskim procesima nego i kao odnos spram vlastitog radničkog tijela. Fenomenologija se kao metodološki okvir u hrvatskoj, ali i šire europskoj etnologiji počinje koristiti relativno kasno, tek početkom 21. stoljeća, no pažljivijim promišljanjem uvidjet ćemo da je fenomenologija zapravo direktno povezana s metodom promatranja sa sudjelovanjem od samog početka. U Argonautima zapadnog Pacifika (1922 (1979): 17-19) Malinowski upućuje “poziv istraživačima da na terenu obrate pažnju na sitnice (imponderabilia) stvarnog života, na tipična ponašanja, na emocionalne, reakcije i postupke sudionika i promatranja određenih događanja” (ibid.: 16). Doista, pogled u prošlost upućuje nas na činjenicu da novi pogledi duguju svoju "inovativnost" dugoj (razvojnoj) povijesti discipline. U tom 
kontekstu, a nadovezujući se na izjavu o neodvojivosti postmodernističkog shvaćanja i interpretacije terena i fenomenologije, od koristi u analizi i ispisivanju uočenih "reakcija i postupaka" može nam biti strategija gustog opisa ${ }^{22}$ (Geertz 1973). U Kulturi, časopisu za teoriju i sociologiju kulture i kulturnu politiku, Bošković (2007) navodi kako se etnografija može razumjeti i kao poseban oblik (ili stil) "zapisivanja" određene kulture, kao poseban stil "podrobnog" (ili detaljnog - engl. thick) pisanja i zaključuje da ono na što se u krajnjoj instanci svodi antropološka analiza jest "detaljan opis" (engl. thick description) (ibid.: 12). Međutim, gusti opis nije samo strategija pisanja ili zapisivanja opažanja, a u konačnici i znanstvenih rezultata. Možemo ga promatrati i kao analizu "protoka simbola" (ibid.: 11) među istraživanom grupom, odnosno kao način na koji sagledavamo i “čitamo” simbole. U spoju iščitavanja simbola i primjećivanja reakcija, emocija i gesta, suvremena etnografija kao kvalitativna metoda istraživanja kulturnih realnosti može značajno doprinijeti spoznavanju svijeta u različitim disciplinarnim dimenzijama.

\section{5. Povijesna metoda}

Povijesna metoda u ovom je radu kombinirana s uvriježenim etnološkim metodama polustrukturiranog intervjua i promatranja sa sudjelovanjem iz nekoliko razloga:

1. nepostojanje striktne feminističke metodologije upućuje na kombinaciju raznovrsnih tehnika saznavanja o ženskim iskustvima (v. Škrbić Alempijević, Potkonjak i Rubić 2016: 109-115);

2. zbog kontekstualiziranja i situiranja društveno-povijesne pozicije radnica;

3. zbog komparacije pisanih izvora u odnosu na sjećanja;

22 “Geertz se smatra jednim od osnivača 'interpretativne' ili 'simboličke' antropologije. U knjizi eseja The Interpretation of Cultures (1973) počeo je od pretpostavke njemačkog sociologa Maxa Webera (18641920) da ljudska bića žive unutar mreža značenja koje su ona sama izatkala i koje nastavljaju da tkaju. Ljudi pokušavaju da shvate svet oko sebe i pridaju mu značenja za sebe i po sebi. U antropologiji se ove mreže značenja kolektivno nazivaju kulturom, dok je njihovo sâmo značenje stvar simbola. Prema tome, antropologija je, između ostalog, usporedno proučavanje kultura, odnosno analiza protoka simbola. Za Geertza, etnografija je predstavljala specifičan način 'zapisivanja' kulture, posebnu vrstu 'gustog' pisanja. Zato je antropološka analiza, prije svega, bila pokušaj 'gustog opisivanja' (engl. thick description). Ovaj je termin Geertz posudio od engleskog filozofa Gilberta Rylea (1900-1976) koji objašnjava distinkcije između, s jedne strane, 'tankog opisivanja' (engl. thin description), koje se bavi samo pojavnim stvarima, i, s druge strane, opisivanja suštine onoga što se zaista događa (kroz 'gust opis') (Ryle, 1968)" (Bošković 2007: 11). 
4. zbog ukazivanja na pretpostavljenu maskulinizaciju javnog rada i općenite nevidljivosti žena u povijesnim izvorima, a koja se veže uz njihovu ekonomsku aktivnost.

Povijesna metoda istraživanja podrazumijevala je uvid u primarne i sekundarne povijesne izvore i njihovu kritičku analizu. Konzultacijom s kolegama povjesničarima definirala sam osnovne arhivske izvore koji bi mogli doprinijeti boljem razumijevanju pozicije i uloge rovinjskih radnica na prijelazu iz 19. u 20. stoljeće. Njihovi su mi savjeti i usmjeravanja bili iznimno dragocjeni za snalaženje u opsežnoj dostupnoj građi. Najprije sam konzultirala Knjigu radnica TDR-a iz 1872. godine u prostorima same Tvornice, gdje se knjiga i čuva, zatim rovinjske matične knjige: knjige rođenih, vjenčanih i umrlih te prijepis izvornika Statuta Grada Rovinja (Statuto Municipale di Rovigno) iz 1531. godine. Ako uzmemo u obzir period obuhvaćen doktoratom (1872.1970.) i ograničenja zbog zaštite privatnosti kojima podliježu dokumenti novijeg datuma, analizom sam obuhvatila period od 1816. do 1917. kroz Knjigu rođenih, od 1825. do 1907. kroz Knjigu vjenčanih i od 1836. do 1913. kroz Knjigu umrlih. Takvim vremenskim rasponom željela sam sagledati dostupne povijesne podatke o ženama, s posebnim osvrtom na ekonomsku aktivnost netom prije otvaranja velikih tvorničkih pogona, dakle u prvoj polovici 19. stoljeća, te u vrijeme industrijskog razvoja, odnosno na samom prijelazu iz 19. u 20. stoljeće.

Kako su brojni povjesničari dokazali, matične knjige predstavljaju bogat izvor za istraživanje društvene povijesti zbog toga što ukazuju na društveni status. Osim podataka o bračnom stanju, dobi krštenja ili vjenčanja, zakonitosti potomaka i slično, matične knjige nam govore i o ekonomskoj povijesti jer je društveni status nerijetko povezan upravo $\mathrm{s}$ određenim zanimanjem. $\mathrm{U}$ istraživanju povijesti zdravstva na primjeru matičnih knjiga umrlih povjesničar Jakov Jelinčić navodi da je u Vodnjanu “najčešće zanimanje [je] poljoprivrednik (agricola), rjeđe nalazimo status posjednika (possidens i possidente), zatim zemljoradnik-posjednik (agricola-possidens), rjeđe građanin (civilis), zidar (murarius), zlatar (orefice), drvodjelac (faber lignarius), kovač (faber ferrarius), gostioničar (caupo), krojač (sartor), postolar (sutor), sluga (famulus), 
služavka (famula), bilježnik (notarius), sudac (iudex), svećenik (sacerdos), liječnik (medicus) i mnoga druga" (Jelinčić 2006: 554).

Primijetit ćemo kako se od ženskih zanimanja spominje samo jedno, ono služavke. Da su matične knjige izvrstan izvor podataka o ekonomskoj povijesti potvrđuje, između ostalih, i rad Lane Krvopić (2013). Pišući o povijesti Tinjana na temelju analize knjiga krštenih, Krvopić ističe da "uz ime i prezime kumova [odnosi se na muškarca i ženu] najčešće se bilježi da je dotični bio seljak (rusticus) ili poljoprivrednik (agricola). No, osim poljoprivrednika, kao kumovi se spominju tkalci (textor), građani (cives), posjednici (possidens), obućari (sutor), trgovci (mercator), plemeniti ljudi (nobiles, nobiles civis, nobiles rusticus), sluge (serva), kovači (faber), učitelji (magister), piljari (caupo), krojači (sartor) i dr. Socijalni status roditelja i kumova je uglavnom bio isti - seljacima i poljoprivrednicima u pravilu su kumovi osobe takvoga socijalnog statusa, kao što su posjednicima najčešće kumovi bili drugi posjednici ili plemeniti građani. No, kod 55-ero nezakonite djece njih 42, ili 78\%, imalo je barem jednog kuma plemenita podrijetla (nobiles, nobiles rusticus, nobiles civis), posjednika (possidens), piljara (caupo), obućara (sutor) ili krojača (sartor) bez obzira kojemu socijalnom statusu je pripadala majka" (Krvopić 2013: 54). Ženska se zanimanja ovdje uopće ne spominju. Na koji način onda sagledavati društvenu poziciju žena kroz povijest?

O "nevidljivosti žena" Mirjana Gross piše u kontekstu znanstvenog susreta feminizma i historiografije. "Feministička znanstvena kritika srela se sa dva tipa etablirane, profesionalne historiografije. To je najprije tradicionalna historiografija koja se oblikovala u drugoj polovici 19. stoljeća, a glavna joj je tema istraživanja bila politička povijest, s težištem na idejama i namjerama istaknutih osoba, tj. 'slavnih muževa' kako bi rekli hrvatski pisci 19. stoljeća. Zato su žene u toj povijesti 'nevidljive'. Drugi tip znanstvene historiografije sa socijalnim i antropološkim usmjerenjem nastajao je gotovo istovremeno s "historijom žena"' (Gross 1993: 56-57). Feministkinje su pri tom susretu najprije ispunjavale "prazna mjesta" u povijesti kompenzacijom, govoreći o velikim vladaricama, znanstvenicama i slično, prateći time logiku tradicionalne historiografije. Ono što je dovelo do druge historiografije, one s 
antropološkim predznakom, odgovara postupnom procesu ili tzv. prijelaznoj historiji, koju zagovara Gerda Lerner, a koja postojećim općim kategorijama prema kojima povjesničari organiziraju svoj materijal dodaje nove kategorije, kao npr. seksualnost, reprodukciju, učenje i internalizaciju spolnih uloga, žensku svijest, vrednote i mitove o ulozi spolova, seksualni simbolizam itd. (Sklevicky 1996: 14). Takvim istraživanjem žene (one odmaknute od herojskog povijesnog mita) postaju "vidljivije". Iako i Gross (1993: 56-57) i Mogorović Crljenko (2006: 7-14) napominju da se o ženama i ranije pisalo te da su i žene pisale, takva su pisanja vrlo partikularna. Nešto optimističnije, Gross navodi primjere historiografske tradicije opatica te francuskih i talijanskih srednjovjekovnih i renesansnih spisateljica koje nam ostavljaju obiteljske kronike i osobne memoare (1993: 58), dok Mogorović Crljenko naglašava kako se o ženama pisalo, ali uglavnom kao o "drugom spolu" (2006: 12). No s obzirom na malobrojne primjere opatica i učenih renesansnih spisateljica u odnosu na pretežitost žena koje nisu mogle steći obrazovanje, pa stoga njihov glas stoljećima nismo čuli, smatram da takve svijetle iznimke "samo" potvrđuju pravilo.

No, nije samo historiografija imala muški predznak. Žene su teško vidljive i u drugim izvorima koji omogućavaju saznavanje o prošlosti, što će reći da je cjelokupni europski svjetonazor, reflektiran u pisanim i vizualnim izvorima, imao muški predznak. Takav društveni status bio je utemeljen na tradicionalnome patrijarhatu koji je davao temeljno značenje socijalnomu životu. "Prihvaćanje predrasuda o ženskoj inferiornosti oblikovalo je znanstvene istine od filozofskih, medicinskih, bioloških i pravnih. Aristotelova teza o ženskoj ništavnosti uzimala se kao znanstvena paradigma do 17. stoljeća" (Čačinovič 2011: 105). Logika potpunoga isključenja žena iz javnoga prostora izliku je nalazila i u Božjoj riječi: “"Stoga Bog pusti tvrd san na čovjeka te on zaspa. Bog mu izvadi jedno rebro, a mjesto zatvori mesom. Od rebra što ga je uzeo čovjeku napravi ženu'. Nepovoljno tumačenje za ženu vezano je i za opis prvoga grijeha $u$ kojem je žena za koju je krivo tumačeno da je stvorena 'druga', prva napravila grijeh" (Mihaljević 2016: 150-151).

Kao što je povijest feminističke misli kompleksna s puno obrata i kritika, tako se i povijest žena suočavala s izazovima uključivanja ženskog pogleda i ženskih priča u 
znanstveni diskurs, tražeći načine za što ispravnijim i korisnijim bavljenjem ženskim pitanjem. Od najranijeg prihvaćanja rodno uvjetovanih dihotomija koje otvaraju put Ženi kao povijesnom subjektu, preko prvih prepreka kada se potencijal her-story istrošio, a povjesničarke su nailazile na znatne poteškoće u nastojanju da svoja saznanja integriraju s ostalim dostignućima historiografije i izbjegnu segregaciju ženske povijesti, traganje je dovelo do razvoja rodne povijesti, a konačno i "rata teorija" uvjetovanih postmodernističkom relativizacijom "povijesne istine” (Ograjšek-Gorenjak 2014: 11-21).

Zbog navedenih problemskih čvorišta, kojima ćemo se u narednim redcima vraćati i osvijestiti gotovo jednake teorijske prepreke i misaone vježbe i u povijesti i u etnologiji, jasno je da je uvođenjem povijesne perspektive rad osnažen ne samo u metodološkom već i u empirijsko-teorijskom smislu. Analizom primarnih povijesnih izvora želi se istražiti na konkretnom rovinjskom primjeru ekonomska aktivnost žena, njezina povezanost $s$ procesima $i$ značenjima emancipacije te maskulinizacija industrijskog rada kao vid društvene kontrole.

\section{6. Metoda ankete}

Metoda ankete odabrana je u posljednjoj fazi istraživanja. Statističkim sam podacima željela pokazati razinu općeg razumijevanja pojmova sardellina (radnica $\mathrm{u}$ tvornici za preradu ribe) i tabacchina (radnica u tvornici za preradu duhana) među stanovnicima Rovinja, zatim i asocijacije na navedena zanimanja i znanje ili stavove o uvjetima rada i položaju radnica. Takvom orijentacijom nastojala sam utvrditi (ne)postojanje društvenog i kulturnog pamćenja na temu industrijske prošlosti Rovinja s fokusom na radnicama te razliku između individualnih sjećanja radnica i kulturnog pamćenja, ako ono postoji.

$\mathrm{Za}$ anketu sam koristila google form online anketu koja se sastojala od 15 pitanja, razvijenih nakon što je provedena osnovna analiza življenih iskustava i sjećanja, a koja su se referirala na istraživačka pitanja disertacije. Kako bi anketa bila što 
uspješnija, odlučila sam se za prigodni neprobabilistički ${ }^{23}$ uzorak. S obzirom na specifičnost teme i istraživačkih pitanja te cilja ankete, takva je odluka bila jedina moguća. Anketom sam uključila vlastite poznanike, njih 44, koji su bili dostupni online (valjana email adresa i pristup internetu u trenutku istraživanja), a jedini je kriterij bio da su stanovnici Rovinja ili šire okolice, odnosno da su upoznati s općom povijesti Rovinja. Prilikom uzorkovanja, osim ovog specifičnog kriterija, pazila sam da budu jednako zastupljena oba spola, težila sam uključiti građane u dobi od 18 do 70 godina (kriteriji su bili punoljetnost i poznavanje rada na računalu) različitih profesionalnih profila i stručnih interesa. Anketa je bila otvorena 10 dana. Od 44 ispitanika, njih 27 je odgovorilo na anketu.

Uz klasične etnološke metode istraživanja, smatram da su povijesna metoda $\mathrm{i}$ sociološka metoda ankete snažno obogatile proces istraživanja i sam rad, s obzirom na to da je cilj rada analiza uloga i položaja rovinjskih radnica od osnutka tvorničkih pogona sve do 1970. godine. Analiza je moguća jedino komparacijom sjećanja i življenih iskustava te je $\mathrm{u}$ tom kontekstu istraživanje kolektivnog naspram individualnom sjećanju nužno kako bi se obuhvatio povijesni aspekt rada s jedne strane i suživot s radnicama s druge.

\section{7. Feministička metoda}

Iako smo ustanovili da striktne feminističke metodologije nema, potrebno je zaključiti poglavlje o metodologiji koja nam pomaže u rasvjetljavanju ženskih intersubjektivnih odnosa te njihovih radničkih položaja i uloga, i to tako da se strateški povežu sve spomenute metode. Dosad smo govorili o etnografskim, povijesnim i sociološkim metodama proučavanja ženskih radničkih iskustava. Tim iskustvima, dakle,

\footnotetext{
${ }^{23}$ Neprobabalistički uzorak određuje se u skladu s određenim kriterijima istraživača, za razliku od probabilističkog koji se temelji na kriteriju matematičke vjerodostojnosti. Postoji pet vrsta neprobabilističkog uzorka:

1. kvotni uzorak - izabiru se stratumi (npr. prema spolu, stručnoj spremi i dr.),

2. prigodni uzorak - ispitivanje dostupnih pojedinaca (npr. ispitivanje stavova studenata nekog fakulteta tako da anketar dođe na neko predavanje i podijeli upitnik),

3. uzorak dobrovoljaca,

4. uzorak snježne grude (engl. snowball) - svaki ispitanik nam identificira sljedećeg ispitanika,

5. namjerni uzorak - (npr. stručnjaci) (Dario Pavić, "Uzorci i uzorkovanja-kvantitativne metode istraživanja", neobjavljeno predavanje).
} 
prilazimo iz rakursa triju, u ovom radu, kompatibilnih disciplina. One nam s jedne strane pomažu obuhvatiti i shvatiti kompleksnost ženskog pitanja, a s druge ograničiti se na ono što je od interesa ovom radu - žene i industrijski rad kroz period od stotinu godina. Feminizam nije znanstvena disciplina per se, nego društveni pokret. Feminizam stoga ne razvija vlastitu metodologiju, već se kao pokret kreće između različitih disciplina: filozofije, antropologije, povijesti, ekonomije, pedagogije, artikulirajući poziciju žena u danoj oblasti te primjenjujući odgovarajuću metodologiju kako bi se ostvario specifičan istraživački ili zagovarački cilj. Međutim, činjenica je da je feminizam u svojoj mnogostrukosti i dugoj povijesti razvio strategije te identificirao bolje i lošije načine istraživanja ženskih iskustava, a koje naknadno informiraju i obogaćuju tradicionalne metode saznavanja. Sandra Harding u knjizi Feminism and Methodology (1987) ističe da postoje određene metodološke strategije korištenja tradicionalnih metoda saznavanja (slušanja ili intervjuiranja, promatranja i analiziranja povijesnih izvora) kao i "distinktivne karakteristike feminističke analize", no odbacuje mogućnost definiranja "distinktivnih karakteristika feminističke metode" (Harding 1987: 1-2). Feminističku metodološku strategiju koja "dodaje žene" kao subjekt u istraživanjima, ističući znanstvenice, poznate žene iz drugih polja i žrtve muškog nasilja, Harding naziva "aditivnom strategijom". Takva se strategija, nalik kompenzacijskom feminizmu u povijesti, ograničava na upis žena u korpus povijesti znanosti s ciljem poticanja kritičkog čitanja povijesti, osvješćivanja prisutnosti žena, njihova javnog djelovanja i sistemske opresije (ibid.: 4). Kod distinktivnih karakteristika feminističke analize Harding apelira najprije na nove empirijsko-teorijske izvore koji u analitičkom okviru ne favoriziraju perspektivu bijele, heteroseksualne pripadnice srednje klase, zatim na novu svrhu istraživanja okrenutu potrebama istraživanih žena te, konačno, na novi tretman predmeta istraživanja koji promovira istraživanje "odozdo", a kojim se pokušava dokinuti istraživačka superiornost (ibid.: 69).

Usporedimo li distinktivne karakteristike feminističke analize s istraživačkom pozicijom i metodološkim pravcima (povijesna metoda, polustrukturirani intervju, promatranje sa sudjelovanjem) koji su odabrani kao tehnika sakupljanja informacija, uočiti ćemo da su sve karakteristike zadovoljene: 
1. rad se temelji na intersekcijskoj analizi roda, klase i nacionalnosti,

2. rad ima za cilj dati glas radnicama u procesima valorizacije njihove društvene uloge,

3. istraživanje se (koliko je god moguće, v. uvod) temelji na istraživanju "odozdo", unutar vlastite zajednice, imajući na umu i poštujući društvene norme.

Uz druge pokušaje definiranja postulata feminističke metodologije, za naš je rad značajno istaknuti još sociologinju Mariu Mies (1991), koja potonju formulira kroz kombinaciju tradicionalnih metoda i feminističko-teorijskih zahtjeva. Mies predlaže definiranje feminističke metodologije kroz davanje prednosti:

1. parcijalnom nasuprot vrijednosno neutralnom,

2. "pogledu odozdo" nasuprot "pogledu odozgo",

3. aktivnom emancipatorskom istraživanju nasuprot "promatračkom" istraživanju,

4. transformaciji kao cilju istraživanja nasuprot proizvodnji “znanja” zbog znanja.

Feminističku metodologiju kao odvojak feminističke epistemologije odredile su četiri karakteristike: pojačana uloga refleksivnosti, akcijska orijentacija istraživanja, pridavanje pažnje afektivnim elementima istraživanja i "kreativno, spontano i improvizacijsko" reagiranje na "zatečene situacije" koje se pojavljuju kod istraživačke orijentacije na žensku svakodnevicu (Škrbić-Alempijević, Potkonjak i Rubić 2016: 111112).

Temeljem uvodnih poglavlja nadam se da možemo zaključiti da je metodološka strategija rada istinski feministička u primjeni tradicionalnih znanstvenih metoda iz etnološke, povijesne i sociološke domene; ona privilegira parcijalna (Haraway 1988) znanja, pogled “odozdo", sudioničko nasuprot promatračkom istraživanju (v. Favret Saada 2012), afekt i procesualnost u istraživanju i bilježenju, kao i fleksibilne reakcije na zatečene situacije. 


\section{TEORIJSKI PRISTUP}

\section{1. Feministička antropologija, pregled razvoja discipline}

...no trebalo je proći još gotovo pola stoljeća do znanstvene artikulacije zdravorazumskog pitanja o (praznom) mjestu žena u povijesti (Sklevicky 1996: 13). ${ }^{24}$

Korijene antropologije žene, ${ }^{25}$ kao i drugih žensko orijentiranih znanstvenih disciplina, nalazimo u sufražetskom pokretu (ujedno definiranom kao prvi val feminizma, a koji je trajao od 1880. do 1920. godine). Pokret prije svega karakterizira borba za pravo glasa žena, no jednako im je bila važna i borba za egzistencijalna prava. Djelovale su ponajprije javnim osvještavanjem opresije nad ženama, i to ne samo na individualnoj, svakodnevnoj razini, već i upozoravajući na nevidljivost žene u javnom diskursu kroz povijesno, društveno, političko i druga očišta. Drugi feministički val, koji vremenski lociramo u rane 1960-e i koji traje sve do 1980-ih, karakterizira naglasak na dokidanju nejednakosti u svim sferama ljudskog djelovanja. Drugi se feministički val više ne bavi zahtjevima za pravo glasa žena (koje, uzgred rečeno, ni tada nisu imale sve žene), ${ }^{26}$ nego se zalaže za de facto ravnopravnost. Činjenica da je u ta dva desetljeća feminizam doživio svoje najveće pobjede, od kojih neke, nažalost, ostaju i vrhunci onoga što je feminizam postigao, ${ }^{27}$ potvrđuje potrebu za nastavkom pokreta, a time i relevantnost feminističke antropologije u smislu kritičkog propitivanja tema i pristupa pokreta u akademskom, ali i širem društvenom kontekstu. Sinergija feminističkog aktivizma i njegov znanstvenoistraživački aspekt posebice će doći do izražaja u narednom razdoblju. Tako se pod utjecajem dekonstrukcije i postmoderne feminizam

\footnotetext{
${ }^{24}$ Vremenski raspon o kojem je riječ odnosi se na razdoblje od osnivačke skupštine feminističkog društva Ženski pokret u Zagrebu 1925. godine, kojim su žene tražile pravo glasa kao nužan (mada ne i dovoljan) uvjet njihova ravnopravnog ulaska u javni život, do pojave znanstvenih promišljanja o položaju i pravima žena u društvu.

25 “Težnja za izgradnjom takve socijalne antropologije koja će radikalno preispitati svoje korene i granice i redefinicijom svojih postulata omogućiti da žena u antropološkoj teoriji i praksi postane 'vidljiva', a u društvu prisutnija no dosad, najizrazitija je u američkoj antropologiji. Ova težnja poprimila je obrise akcijske antropologije koja pažnju usmerava na nove horizonte analize polnosti u ranijim i savremenim društvima i već se oformila u novu orijentaciju koja je, utemeljena na već impozantnom broju radova i živih diskusija, dobila naziv antropologija žena (anthropology of women)" (Papić i Sklevicky 2003: 12).

${ }^{26}$ Žene su pravo glasa u Hrvatskoj (Jugoslaviji) dobile "već" 1945., ali su zato pojedine Švicarke na to pravo čekale sve do 1971., dok je onima u kantonu Appenzell Innerrhoden pravo glasa odobreno tek 1991. godine.

${ }^{27} \mathrm{https}$ ///voxfeminae.net/autorice/ivana-mihaela-zimbrek/, pristup 25. 11. 2019.
} 
ranih 1980-ih još čvršće isprepleo s antropologijom, pa su feministkinje, sada već trećeg vala, sve više osvještavale $i$ isticale heterogenost ženskog iskustva, tvoreći platformu za razvoj jednog od najplodonosnijih perioda feminističke teorije i debate. Konačno, Shelby Knox je 2010. godine objavom na svom blogu samodeklarativno postala pokretačica četvrtog vala feminizma. Međutim, dosad nije uočen njegov značajniji teorijski doprinos, već se njime isključivo artikuliraju internet i digitalna revolucija kao tehnološki dosezi koji omogućavaju snažniji ženski angažman i lakši pristup informacijama.

Pisanje žena $\mathrm{i}$ pisanje o ženama $\mathrm{u}$ raznim literarnim formama $\mathrm{s}$ jasnim ukazivanjem na nejednakosti između muškaraca i žena (a kasnije i među ženama) kroz prizmu feminističkog pokreta postepeno razvija feminističku antropologiju kao poddisciplinu kulturne antropologije $\mathrm{u}$, ponajprije, anglosaksonskom svijetu. Dominantno (kvantitativno, a kvalitativno je tek valjalo dokazati) prisustvo žena na polju etnologije i kulturne antropologije (i) u Hrvatskoj (Jugoslaviji) 1980-ih godina omogućilo je, nešto zakašnjelu, ali ipak recepciju feminističke antropologije kao poddiscipline antropologije ili barem kao analitičkog okvira u etnoantropološkim istraživanjima. Feministička je antropologija imala (i još uvijek ima) dvostruki cilj: afirmaciju etnologinja i kulturnih antropologinja i preslagivanje dotadašnjih etnoantropoloških znanja artikuliranih kroz mušku perspektivu. ${ }^{28}$ Nakon početnog entuzijazma, predvođenog iznimnom ličnošću Lydije Sklevicky, u domaćim je znanstvenim krugovima nastupilo zatišje, koje do danas nije značajnije dokinuto. Čini se kako se feministička antropologija u domaćim okvirima bez puno buke stopila s radovima većine hrvatskih etnologinja i kulturnih antropologinja ili je "feminizacija etnologije uključila pitanje roda puno prije sličnog feminističkog zahtjeva" (Škokić 2004: 9). Hrvatske su etnologinje (a u rijetkim slučajevima i etnolozi), ${ }^{29}$ svaka na svoj

\footnotetext{
${ }^{28}$ Vrijedno je prisjetiti se promišljanja na temu uvođenja feminističke perspektive u hrvatski etnološki diskurs koje je ponudila Ines Prica, a koja fokus o njezinim začecima s rodne hijerarhije premješta na generacijsku. "Kad su u kasnomodernističkom znanstvenom kontekstu, dodatno obilježenom i radikalnom društvenom 'smjenom paradigmi', hrvatske etnologinje pristupile izravnoj kritici akademske, kulturnopovijesne etnologije i 'štovatelja Gavazzijeva autoriteta' te preuzele vlast $\mathrm{u}$ znanstvenoistraživačkom interdisciplinarnom području (etno-antropologije, etnologije i folkloristike) to su, možda i više nego kao žene, učinile upravo kao predstavnice poletne, znanstvene i socijalne mladosti, nositeljice inovativnih pristupa i približavanja etnologije aktualnoj sceni života” (Prica 2004: 42).

${ }^{29}$ Primjerice, Jadran Kale u tekstu "Nadnaravni karakter žene ocrtan otočnim predajama šibenskog kraja" (1995/1996).
} 
način, često bez naglašavanja striktno feminističke pozicije, u vlastiti rad unosile strategije okrenute $\mathrm{k}$ istraživanju odozdo $\mathrm{i}$ parcijalnim znanjima $\mathrm{s}$ istančanim senzibilitetom za heterogena iskustva i fine niti odnosa koje su ih povezivale. ${ }^{30}$

Feministička se antropologija formira na globalnoj razini početkom 1970-ih kao jedna od mnogih reakcija na androcentričnu i kolonijalnu tradiciju antropologije te kao dio društvenih pokreta marginalnih skupina (pokret studenata, crnaca, žena, homoseksualaca $\mathrm{i}$ dr.) "koji pokazuju jasnu težnju da se redefiniraju znanstveni i objektivni sudovi o njima samima i traže drugačiju, primjereniju konceptualizaciju svojih osobina, problema i alternativa" (Papić i Sklevicky 2003: 9). Jasno je kako se svi ti pokreti isprepliću, utječu jedan na drugog te međusobno izazivaju uvijek i iznova, dosežući vrhunac "teorijskog rata" s općom afirmacijom postmodernizma. Dotadašnja je antropologija morala, dakle, preispitati vlastitu poziciju iz dvije perspektive - one "muškog znanstvenog" glasa, s obzirom na to da su dotadašnje kategorije i instrumentarij proizvodnje znanja isključivali žene iz etnografskih podataka ili ih označavale kao Druge, te iz perspektive kolonijalne tradicije unutar koje se kroz znanstveni diskurs istraživača/etnologa, s nerijetko uključenim "hegemonijskim treningom”, istraživane kulture određuju u neravnomjernom odnosu moći. S pojavom postmodernizma antropologija (kroz feminističku antropologiju kao poddisciplinu) postaje aktivni dionik šire kritike nevidljivosti žene kroz povijest i suvremenost. ${ }^{31}$

Kako će Škokić (2001: 6) naglasiti, gotovo je nemoguće ispisati potpuni pregled razvoja feminističke antropologije. Tome je tako zbog diskrepancije unutar antropoloških škola (američke i zapadnoeuropske) i pozicija samih znanstvenica, ali i zbog činjenice da je subjektivistička priroda postmodernizma izazivala brojne reakcije i iz svake se reakcije rađalo nešto što je moglo unaprijediti rad feministkinja, ali i antropologa uopće. Podjednako tako, ni ovaj rad nema za cilj po tko zna koji put

\footnotetext{
${ }^{30}$ Posebno je hvaljen zbornik radova Fear Death and Resistance: An Ethnography of War: Croatia, 1991-1992, urednica Čale Feldman, Prica i Senjković, koji u pojedinim radovima spaja feminističku i ratnu etnografiju.

${ }^{31} \mathrm{O}$ dramatičnim obilježjima statusa žene u društvu i u kontekstu modernoga doba govore brojne tužne činjenice poput one o oduzimanju prava na starateljstvo nad djecom, kako je bilo u Francuskoj sve do 1907. godine. U Njemačkoj su pravo da budu skrbnice vlastite djece žene dobile tek 1953., a pravo da se mogu zaposliti bez supružnikova dopuštenja 1977. godine (Zaharijević 2012 prema Mihaljević 2016: 150 i Anić 2010: 223).
} 
donositi pregled svih feminističkih teorijskih pravaca. Važno nam je kroz ovo poglavlje ukazati na glavna epistemološka čvorišta koja su dovela do onih pravaca koje ćemo u ovom radu koristiti: revidiranu teoriju stajališta (engl. standpoint theory) s vrhuncem $\mathrm{u}$ teoriji situiranog znanja i intersekcionalizam.

Prvi koraci feminističke antropologije, u skladu s "aditivnom" strategijom prvih feministkinja ili "kompenzacijskom" povijesti rane historiografije žena, bili su usmjereni na pronalaženje žena u etnografskom pismu. U uže etnografskom, metodološkom smislu valjalo je nova istraživanja (terenska) usmjeriti na žene, na njihovu svakodnevicu $\mathrm{i}$ progovoriti o njihovim iskustvima. ${ }^{32}$ Inspirirana ranijim etnografskim i antropološkim radovima, primjerice onim Margaret Mead, ali ponajviše tada već dvadeset godina starom izjavom Simone de Beauvoir: "Žena se ne rađa kao žena, već to postaje” i “Ona se determiniše i razlikuje od muškarca, a ne on u odnosu na nju - ona je nebitno prema bitnom. On je Subjekat, Apsolut; ona je Drugi” (De Beauvoir prema Škokić 2001: 7), feministička antropologija uvodi pojam roda. Rod je, za razliku od spola, društveno i kulturno uvjetovana kategorija. Mead će u predgovoru knjige iz 1950. godine gotovo u samoobrani reći kako je to možda jedna od najlošijih recepcija njezinih radova jer je po objavljivanju knjige bila optuživana da je Spol $i$ temperament pisala s pretpostavkom da ne postoje spolne razlike (Mead 2004 [1950]: 7), anticipirajući time pojam roda koji se tek od 1970-ih počinje razmatrati nasuprot ideji o biološki uvjetovanim spolnim razlikama. Budući da je biološki redukcionizam, koji muško-ženske odnose vidi kao odraz spolnih identiteta, dominirao u gotovo svim znanostima, koncept roda je bio dobrodošao jer je objašnjavao razlike u muško-ženskim ulogama kroz sferu društvenog određivanja (Škokić 2001: 7). Karakteristika prvog razdoblja feminističke antropologije ogleda se i u univerzalističkom shvaćanju ženskog iskustva, prije svega u ideji o interkulturalnim aktivnostima koje bi bile zajedničke svim ženama i inzistiranju na univerzalnoj dominaciji muškaraca (ibid.: 8). Osim toga "u namjeri koju je moguće čitati kao stvaranje velike društvene teorije koja će dati konačne odgovore i udariti temelje za političkom promjenom u korist žena, feministkinje su izostavile ili previdjele da je spol jednako društvena kategorija kao i rod te da se rod ne može shvaćati kao stalan i povijesno nepromjenjiv društveni konstrukt" te da je

\footnotetext{
${ }^{32}$ Vidi više o feminističkom empirizmu u Škrbić Alempijević, Potkonjak i Rubić (2016: 103-104).
} 
"razdvajanje spola i roda samo još jedan oblik etnocentrizma" (ibid.). Jasno je kako su ovakve esencijalističke ideje ubrzo naišle na negativnu reakciju. Akademski glas heteroseksualne bjelkinje srednje klase nije mogao biti reprezentativan za sve ženske glasove.

Koliko je 1970-ih fokus antropologije žena bio na sličnostima i univerzalizmu, toliko su različitost i partikularizam zaposjeli (feminističku) antropologiju od 1980-ih nadalje. Žustre rasprave druge faze feminističke antropologije dovele su do drastičnog raskola unutar pokreta, a slijedom toga i do krize feminističke antropologije. Ključno pitanje koje je proizašlo iz tih rasprava bilo je ima li bez jasno definiranog ženskog subjekta feminizam smisla. Usprkos debatama o potonjem, ili možda upravo zbog njih, tijekom 1980-ih godina udareni su temelji feminističkoj epistemologiji. Cilj takve epistemologije je oblikovanje znanja iz ženske perspektive. To je oblikovanje relacijsko, odnosno dvosmjerno jer se istodobno nastoji definirati pozicija istraživača te subjekt istraživanja koji se nastoji sveobuhvatno predstaviti. Godine 1986. Harding predlaže klasifikaciju feminističke epistemologije na tri smjera:

- feministički empirizam,

- teoriju stajališta (engl. standpoint theory),

- postmodernistički feminizam.

Feministički empirizam ističe da su seksizam i androcentrizam društvene kategorije, ali smatra da se one daju ispraviti te da je moguće ponuditi novi pogled na procese oblikovanja znanja adekvatnom primjenom postojećih metodoloških normi znanstvenog istraživanja. Klasični empirizam zanemaruje činjenicu da istraživač utječe na rezultate istraživanja. On ujedno pretpostavlja da se striktnim provođenjem empirijskih metoda višeslojni identiteti istraživača mogu ukloniti, odnosno zanemariti. Suprotstavimo li tome temeljnu ideju feminističkog empirizma da feministkinje mogu proizvesti objektivnije znanje od muškaraca (odnosno "nefeminista"), uviđamo da feministički empirizam, s obzirom na to da ne daje primat metodi i dovodi u pitanje njezinu objektivnost, odnosno njezinu metodološku validnost, zapravo subvertira empirizam. Je li onda zaista moguće klasičnim empirizmom spoznati svijet iz pozicije žene ako znamo da njegove metode epistemološki kreću iz dominantne muške 
znanstvene pozicije? Uz to, Harding ističe ključni nedostatak feminističkog empirizma. Feministkinje znaju da pitanje androcentrizma i seksizma nije dovoljno sagledati kroz analitiku i interpretaciju rezultata istraživanja, već je jednako važno osvijestiti odabir problema istraživanja kao jedan od izvora androcentričnog biasa. Međutim, empirizam nema metodološki instrumentarij kojim bi tretirao pitanje selekcije istraživačkih problema (Harding 1986: 24-25).

Korak dalje u promišljanjima metoda saznavanja iz ženske perspektive predstavlja teorija stajališta. Kako će sociologinja Dorothy Smith isticati, žensko iskustvo je temelj feminističkog znanja i upravo takvo znanje može promijeniti sociologiju kao disciplinu. Ženski životi mogu pružiti početnu točku novih kritičkih razmatranja ne samo o ženskim životima nego i o muškim i, što je još važnije, o njihovu suodnosu (Harding 1992: 443). Pri artikulaciji različitosti, teorija stajališta zahtijeva promišljanje (pozicije) izvora znanja i pozicioniranje istraživača: tko istražuje?, iz kojeg ugla?, s kojom namjerom?, koga istražuje?, čija je pozicija “objektivnija”? Stoga se prilikom istraživanja nameću dvije nužnosti:

1. nužnost određivanja grupe koja će najbolje odgovoriti na pitanje opresije,

2. nužnost autorefleksivnosti istraživača.

Teoriju stajališta u feministički rječnik uvodi 1983. godine Nancy Hartsock u knjizi Money, Sex and Power: Toward a Feminist Historical Materialism, ali je kroz tri desetljeća, reflektirajući naizmjenično esencijalističku i dekontruktivističku teoriju, razvijaju brojne feministkinje. ${ }^{33}$ Hartsock ideju posuđuje od Marxa, koji u poziciji proletarijata vidi izvor objektivne istine u određivanju hegemonijskih odnosa (Hartsock 1983: 231). Počevši od pretpostavke da znanje koje nam se nudi nastaje iz dominantnih društvenih pozicija, feministička kritika tvrdi da takvo znanje nije ni potpuno ni primjereno, jer isključuje žene kao subjekt i izvor znanja. Na Marxovu tragu, tek sagledavanjem znanja i iskustva zatomljene (ženske) strane, smatra Hartsock, razotkrit će nam se "istina". Temeljni je cilj, prema njezinu mišljenju, definirati "objektivne" (navodnici moji) tvrdnje kojima žene raspolažu i ponuditi odgovarajuću metodologiju koja bi valorizirala te tvrdnje. Njezin je poduhvat izvor inspiracije, ali i prijepora za generacije feministkinja. Harding će kasnije (1986) objasniti da teorija stajališta tumači

\footnotetext{
${ }^{33}$ Neke od njih su Susan Hekman (1997), Sandra Harding (1986, 1991, 1993, 2004), Patricia Hill Collins (1990, 1997), Maria Mies i Vandana Shiva (2014).
} 
mušku dominantnu poziciju u društvu kao izvor iskrivljenih “istina”, dok će žene, iz svoje podređene pozicije, generirati kompletnije razumijevanje stvarnosti (Harding 1986: 26). Jukstaponirana feminističkom empirizmu, teorija stajališta jasnije artikulira mogućnost saznavanja iz pozicije žena. Međutim, istraživačice koje su sklone empirizmu i pokušaju utemeljenja metodologije društvenih i humanističkih znanosti po principu prirodnih znanosti ne mogu prihvatiti identitet istraživača kao jedan od ključnih faktora u dostizanju “objektivnosti” znanstvenog istraživanja (ibid.). Osim toga, Harding ističe još dva ključna problema koja već tada nagovještavaju ono što će $u$ narednim godinama dovesti do koncepta situiranog znanja i intersekcionalizma:

1. Postoji li takvo što poput ženskog stajališta ako su iskustva žena podijeljena rasnim, klasnim, nacionalnim i drugim identitetima?

2. Nije li teorija stajališta prečvrsto ukorijenjena $u$ problematične politike esencijaliziranih identiteta? (ibid.: 26-27).

U pokušajima da se jasnije definira subjekt feminističkog istraživanja i da se pruži kvalitetan i održiv odgovor na probleme koje je 1986. godine postavila Harding, feministkinje su nudile razna rješenja unutar teorije stajališta. Patricia Hill Collins je, primjerice, razvijala teoriju o zajedničkoj poziciji crnkinja u odnosu na druge žene, a u sličnu se zamku zapetljala i Hartsock s nevjerojatnom tvrdnjom da žene ne čine jedinstvenu poziciju s obzirom na različite identitete, ali da, s druge strane, eurocentrični bijelci zauzimaju upravo takvu, jednoznačnu poziciju (Hekman 1997: 353). Čini se da je feministički zahtjev za univerzalnom kategorijom žene kao jedinom politički operativnom za borbu za ženska prava sputavao određene znanstvenice u prihvaćanju heterogenosti iskustava (kako ženskog tako i muškog), čak i nakon što su postmodernističke teorije upozorile na problematičnost pojma identitet $\mathrm{u}$ jednini, kao i nakon konstruktivističkog pristupa znanju. Kao u začaranom krugu, rasprava se fokusirala na dva ključna pitanja: na koji način prihvaćanje različitih ženskih iskustava utječe na koncept istine kakav feminizam zastupa?, a drugo, ako napustimo jednostruku os analize utjelovljene u konceptu ženskog stajališta, ne gubi li se onda i analitička snaga samog pristupa? (ibid.: 349). 
Postmodernistički val relativizma dodatno je ojačao bojazan od gubljenja valjane epistemološke i metodološke pozicije. Moguću strategiju pristupanja ženskom pitanju dala je Sandra Harding u okrilju koncepta čvrste objektivnosti. Harding odbacuje univerzalnost feminističke teorije stajališta reflektirane $\mathrm{u}$ homogenim ženskim iskustvima, čime izbjegava esencijalizam, dok inzistiranjem na konceptu čvrste objektivnosti osvještava društvenu pozicioniranost svakoga znanja. Ipak, u korist znanstveno valjanog istraživanja, smatra da je nužna kritička evaluacija onih društvenih situacija za koje je vjerojatnije da će generirati najobjektivniju tvrdnju (Harding 1986: 134-142). Upravo će zbog toga Hekman kritizirati ideju čvrste objektivnosti. S obzirom na to da i nadalje marginaliziranim skupinama pripisuje epistemološku prednost, ona smatra da se Harding njome vraća na izvorne (i već pobijene) postulate feminističke teorije stajališta (Hekman 1997: 354). Budući se feminističkom empirizmu zamjerao nedostatak instrumentarija kojim će obuhvatiti problem selekcije istraživačkih pitanja, ${ }^{34}$ Harding ističe sasvim suprotnu situaciju kod teorije stajališta. Autorica smatra da marginalizirani životi (oni koje potonja teorija privilegira u procesima proizvodnje znanja) mogu ponuditi nove znanstvene probleme, odnosno da se ti problemi mogu artikulirati iz pozicije marginaliziranih grupa, ali se ne mogu ponuditi rješenja jer, kako smo ranije pokazali, ne postoji jedno privilegirano očište (Harding 1992: 443).

Poseban doprinos u rasvjetljavanju problema epistemološke prednosti je onaj Donne Haraway (1988). Idejom situiranog, odnosno pozicioniranog i parcijalnog znanja Haraway artikulira teoriju stajališta u puno razrađenijoj i sofisticiranijoj formi negoli itko dotad te prepoznatljivim stilom pisanja osnažuje generacije znanstvenika $u$ procesima propitivanja vlastitih istraživačkih pozicija. Haraway smatra da je objektivnost moguća jedino u kontekstu ograničene lokacije i pozicioniranog znanja. Takva se objektivnost, dakle lokalizirana i s jasno definiranim (smještenim) kontekstom, kritički osvrće na privilegirane pozicije moći iz kojih nastaju dominantni znanstveni diskursi, kao što i kritički promatra pokušaj uključivanja "podčinjenih" stajališta kao preferiranih u procesima konstrukcije znanja. Haraway ističe da "podčinjena" stajališta mogu dovesti u zamku romantizacije i aproprijacije nižih pozicija moći za koje je važno naglasiti da nisu "naivne"; naprotiv, one su u

\footnotetext{
${ }^{34}$ Metode feminističkog empirizma epistemološki kreću iz muške pozicije stoga su istraživačka pitanja nepotpuna.
} 
znanstvenom diskursu poželjnije jer je manje vjerojatno da će nijekati interpretativnu srž znanja (Haraway 1988: 583).

Vidjeli smo kako se pod utjecajem postmodernizma teorija stajališta drastično mijenjala. Dotadašnju ideju o privilegiranom znanju i jednoj istini napustile su $\mathrm{s}$ vremenom i najupornije zagovornice te teorije (Hekman 1997: 357-358). Postmodernizam je kao misaona oluja preokrenuo temelje gotovo svake, a posebno društvenih i humanističkih znanosti. Teoretičari postmodernizma jednako su snažno kritizirali ideje feminističkog empirizma kao i teoriju stajališta, osvrćući se na dotad proklamirane mogućnosti stjecanja jednoznačnog ili univerzalnog znanja žena (u svim mogućim kombinacijama koje su dosad u tekstu spomenute), a posebno na ideju jedinstvenog subjekta. Postmodernizam je temeljem tog spora u feministički tabor donio novu podjelu, onu na esencijalistkinje i dekonstruktivistkinje. Esencijalistkinje smatraju da je feministički subjekt nužan da bi se zadržala valjana epistemološka i metodološka pozicija feminizma, dok dekonstruktivistkinje smatraju da je prostor "prava na subjekt" od početka lažan, jer je svako mjesto subjekta proizvela politika sama (Škokić 2001: 12). Mišljenje da uvođenjem postmodernističkih shvaćanja produkcije znanja feminizam polako gubi društvenu i znanstvenu relevantnost jer mogućnost istraživanja i predstavljanja jedne, istinske ženske priče, iskustva ili povijesti sve više blijedi, za Sandru Harding 1980-ih ne predstavlja slom feminizma. Naprotiv, u svakom kriticizmu vidi mogućnost osnaživanja feminističke epistemologije kroz procese osvještavanja i promišljanja prisutnosti androcentrizma u znanosti (Harding 1986: 28-29).

Ono što danas, s tridesetogodišnjim odmakom možemo uočiti jest da je postmodernizam zaista antropologiji, pa time i feminističkoj antropologiji otvorio prostor "za iskušavanje različitih tekstualnih strategija i pisanje višeglasnih tekstova" (Škokić 2001: 12). Koliko god snažne i uporne kritike navodnog relativizma ovako shvaćenog subjekta i pisanja etnografije bile, žensko pisanje i pisanje za žene u današnjim društvenim i znanstvenim okvirima jednako je važno, relevantno i potentno kao i u začecima feminizma. 


\section{2. Situirano znanje}

Feministička objektivnost se ogleda u situiranom znanju (Donna Haraway 1988: 581).

Sagledavanje uloge i pozicije radnica krajem 19. i kroz sedam desetljeća 20. stoljeća zahtijeva dovoljno širok teorijsko-metodološki okvir da bi se obuhvatila kompleksnost subjekta u smislu povijesnih, političkih i društvenih okolnosti, ali istovremeno i primjenu strategije koja neće pribjeći relativizaciji i time oslabiti doprinos spoznavanju unutar feminističke i industrijske antropologije. Kompleksnost zadatka je više nego očigledna. U uvodnim poglavljima već je rečeno o mojoj vlastitoj poziciji iz koje želim sagledati subjekt istraživanja, o ciljevima i hipotezi rada. Također, prethodna je cjelina u kratkim crtama predstavila razvojnu putanju feminističke antropologije koju (danas) karakterizira eklekticizam te je (gotovo) nemoguće opredijeliti se za jednu valjanu teoriju koja će reflektirati najprije današnju feminističku antropologiju, a potom i znanstveni karakter brojnih antropologa koji se bave ženskim temama.

Zašto je uopće nužno progovarati kroz prizmu feminističke teorije? Što teoriju definira feminističkom? Krenemo li od teme rada, odnosno subjekta istraživanja, ubrzo ćemo uvidjeti da su žene predmet etnoloških razmatranja oduvijek. "Hrvatski etnolozi i folkloristi značajan su dio istraživačkog žara usmjerili na ženske niše ${ }^{35}$ predajne kulture kao ključna mjesta njezina konzerviranja i prenošenja" (Jambrešić-Kirin i Škokić 2004: 8). Ipak, teorijski okvir takvih radova nije sadržavao pridjev "feministički". Godine 1982. Dunja Rihtman-Auguštin ponudila je drugačiji, kritički pogled na ulogu žena u zadružnim obiteljima, uključivši ženu ne samo kao temu istraživanja nego i kao analitički okvir suprotan tadašnjem dominantnom etnološkom diskursu. Pa ipak, ni ona nije etiketirana feministkinjom iako je, kao i druge njezine suvremenice, snažno doprinijela afirmaciji feminističke antropologije u Hrvatskoj. Nadodajmo tome da se ni sama nije tako izjašnjavala, naprotiv, u obljetničkoj kronici iz 1984. godine, povodom trideset i pet godina djelatnosti Zavoda za istraživanje folklora, antropologija žene se ne spominje kao zasebno izdvojeno područje istraživanja, dok se u kronici Dunje Rihtman-

35 "Detaljan opis sadržaja ženskih škrinjica i folklornog repertoara, otkriće pretkršćanskih magijskih praksi i praznovjerja, uz druga zabilježena 'kuriozitetna' obilježja gospodarskog i obiteljskog života seoskih zajednica, legitimirao je etnografske napore terenskog rada i dopunjavao patrijarhalnu sliku zauvijek izgubljenog seoskog sklada" (Jambrešić-Kirin i Škokić 2004: 8). 
Auguštin i Aleksandre Muraj iz 1998. godine, koja afirmira niz novih teorijskih usmjerenja i istraživačkih fokusa unutar historijske, vizualne i ekonomske etnoantropologije, samo uzgred konstatira da se nakon prerane smrti Lydije Sklevicky istraživanje u okvirima antropologije spola obnavlja u radovima Tee Škokić (Đurin, Jambrešić-Kirin i Škokić 2019: 237). Još bi pogrešnije bilo tvrditi da se svako etnografsko pismo može smatrati feminističkim samo zato jer ga je pisala žena o ženskim iskustvima. Što je to što etnografsko pismo čini feminističkim i zašto sam se opredijelila za feminističke teorije u analizi iskustava radnica Tvornice duhana Rovinj?

Kada sam iz osobnih i profesionalnih pobuda odlučila istražiti ulogu rovinjskih radnica u razvoju pretpostavljene ženske emancipacije i jačanju društvene pozicije žena, nisam znala kroz koji bi se teorijski okvir to istraživanje moglo najbolje artikulirati. Čitala sam o tabacchinama kao emancipiranim i dobrostojećim ženama i zamišljala se u poziciji radnice koja ustaje u ranu zoru da bi pospremila kuću, donijela vodu, pripremila doručak koji je morao biti dostatan za četvoro djece, supruga i dvoje staraca, po buri ${ }^{36}$ pješačila do tvornice gdje bi narednih deset sati koncentrirano, spretno i što je brže moguće motala duhan kako bi zaradila plaću, a kada bi navečer umorna došla kući najprije bi u sumrak izbacila tjelesne izlučevine nakupljene tokom dana (u Rovinju, naime, do kasnih 1950-ih nije bilo kanalizacije), kuhala bi, prala, razgovarala $\mathrm{i}$ podučavala djecu te krpala odjeću koju je najmlađe dijete naslijedilo od starijih. Zamišljala sam i kako brzo koračam usred zime noseći toplo umotano jednomjesečno dijete i ostavljam ga na čuvanje jednoj od radnica u tvorničkim jaslicama zajedno s još barem trideset gladnih uplakanih beba. Pitala sam se iz koje je pozicije definirana privilegiranost tih radnica. Povijest kojoj sam imala pristup i koja je oblikovala rovinjski industrijski imaginarij pisali su muškarci, a članak o radnicama (istina, onima u zagrebačkom postrojenju) na koji sam naišla, a da ga je pisala žena, pratio je dio stereotipa ranijih radova (Vlajo 1999: 18). Dakle, ni žena nije mogla proniknuti u žensku problematiku rada. Kako li je to moguće? Odgovor se vjerojatno krije u sljedećem: cilj njezina rada nije bio isti kao cilj mojega, njezino je obrazovanje bilo drugačije od mojeg, vjerojatno nije imala priliku čuti iz prve ruke kako je izgledao dan u životu rovinjske/zagrebačke radnice (neovisno o vremenskom periodu). Iz pozicije

\footnotetext{
${ }^{36}$ Jak i hladan vjetar koji puše s kopna k moru.
} 
radnice, posao nije bio lagan; iz pozicije autorice teksta Radmile Vlajo, djevojke su zapošljavane upravo zbog lakoće ručnog rada.

I Kata Jajnčerova je u svoje bilješke, unatoč autocenzuri generiranoj Radićevim pitanjima iz Osnove za sabiranje i proučavanje građe o narodnom životu (1897), uvodila informacije o životu seoskih žena na sličan način na koji je Radmila Vlajo spomenula radnice u pregledu razvoja Tvornice Duhana Zagreb. U radu Jajnčerove nedostaje "feminističkog i građanskog emancipacijskog naboja" (Đurin, JambrešićKirin i Škokić 2019: 235). U skladu s politikom svoje dvojice starije braće Stjepana i Antuna Radića, ona u tekst ubacuje rudimentarnu socijalnu kritiku u ime ekonomski osiromašenih seljaka s "jasno naznačenom socijalnom borbom za preživljavanje”, poštuje dihotomiju gospodskog i seljačkog u korist potonjeg i žaluje za tradicionalnim oblicima zadružnog i obiteljskog života te patrijarhalnom ženskom ulogom (ibid.: 235236). Analogijom možemo zaključiti da ni tekst Vlajo o tvorničkim radnicama nije pisan s ciljem sagledavanja pozicije i uloge radnica; one su se uglavnom spominjale tek usput, što je onemogućavalo razvoj vidljive ženske povijesti i valorizaciju ženskog industrijskog rada u društvu. Da bismo pisale u duhu feminističke antropologije nije dovoljno tek usput spomenuti žene, pa čak ni, u skladu s aditivnom strategijom, posvetiti im cijelu monografiju, ako cilj takvog istraživanja nije angažiran. Feministička antropologija ne pruža samo (heterogen) subjekt istraživanja, ona pruža nove epistemološke temelje relevantne za sve znanosti. Kada se bavimo ženskim temama ili kojom god drugom temom, a koristimo uvide iz teorija koje razvijaju feministkinje $\mathrm{s}$ ciljem pravednijeg, višeglasnog istraživanja i interpretacije, nepravedno je ne nazvati taj proces, to promišljanje, njegovim pravim imenom - feministička antropologija. Iako su feminističke strategije istraživanja i pisanja prisutne u mnogim radovima naših etnologa, prešućivanje doprinosa feminističke teorije epistemologiji suvremenih znanosti uopće iznova doprinosi jačanju dominantnih (i danas najčešće bijelih, Zapadnih, kapitalističkih...) diskursa koji vrlo rijetko uključuju žensku poziciju, te doprinosi afirmaciji nevidljivosti žena u povijesti i znanosti, a protiv koje se već pedeset godina bori antropologija žena / feministička antropologija, ženska povijest, sociologija roda $\mathrm{i} \mathrm{dr}$. 
U intervjuu "On Standpoint Theory's History and Controversial Reception"37 iz 2016. godine Sandra Harding će izjaviti da teorija stajališta predstavlja organsku logiku istraživanja. Naime, iako je prošlo četrdeset godina od prvih promišljanja teorije, ona je unatoč kontroverzama i danas aktualna. Zašto je tome tako? Harding u intervjuu ističe kako svaka grupa (žene, studenti, etničke manjine, osobe s tjelesnim invaliditetom i sl.) koja se bori za svoja specifična prava u različitim društveno-povijesnim okolnostima borbu započinje sličnom izjavom: "Iz naše perspektive stvari stoje ovako" ili "Iz naše pozicije situacija je drugačija”. Da sam kojim slučajem odlučila istraživanje radničkih iskustava temeljiti na dostupnim povijesnim izvorima i razgovoru s upraviteljima tvorničkih pogona, rezultati bi zasigurno bili drugačiji.

U početku sam smatrala, čitajući feminističku literaturu (od 2009. godine naovamo), da sam odabirom teorije stajališta riješila vlastiti problem definiranja teorijskog (i metodološkog) okvira. Smatrala sam da ću ako sagledam radnička iskustva i predstavim ih kao protuargument pisanoj povijesti, na primjer Bernarda Benussija ili Krešimira Džebe, time objektivnije progovoriti o ulozi i poziciji rovinjskih radnica. Privilegirala sam jednu poziciju nasuprot druge, misleći usput da postoji takvo što kao žensko radničko iskustvo. Osvijestivši, putem terenskog rada, heterogenost ženskih radničkih iskustava, morala sam pronaći novu strategiju kojom bih potencijalno mogla obuhvatiti svu raznolikost iskustava, a da pritom rezultat istraživanja ne bude zbirka naracija i interpretacija. Shvatila sam da je moj zadatak pronaći odgovor na pitanje je li zaista industrijski rad uvjetovao određenu razinu emancipacije i koje su karakteristike te emancipacije? Etnografsko je istraživanje pritom iznjedrilo još dva znanstvena problema: kako adresirati heterogenost ženskih iskustava i pritom rasvijetliti razloge nevidljivosti žena u povijesnim tragovima na konkretnom rovinjskom primjeru. Teoriju stajališta sam, u smislu "organske logike istraživanja", zadržala, ali sam odlučila koristiti njezinu, promišljanjima Donne Haraway, revidiranu i osnaženu verziju. Kako će Haraway reći, ona i druge feministkinje tražile su snažan alat za dekonstrukciju dotadašnjih tvrdnji o "istini” tako što su isticale radikalne povijesne specifičnosti i raslojavale sporne znanstvene i tehnološke konstrukte (1988: 578). Kritiku dekonstrukcije kao metode koja vodi relativizmu Haraway ne rješava totalizmom;

37 Sandra Harding: "On Standpoint Theory's History and Controversial Reception" https://www.youtube.com/watch?v=xOAMc12PqmI, 15. 5. 2016. 
naprotiv, ona relativizam i totalizam vidi kao dvije strane istog novčića. Spas od relativizma nije, dakle, u totalizmu, već u parcijalnom, lokaliziranom, kritičkom znanju koje sadrži potencijal tvorbe mreže odnosa. U politici se to naziva solidarnost, a $\mathrm{u}$ epistemologiji zajednička konverzacija. Za relativizam će reći da je izravna suprotnost totalizmu ideologije objektivnosti; oba negiraju lokaliziranost, utjelovljenje i parcijalne perspektive; oba nam onemogućavaju da dobro vidimo. Relativizam i totalizam su “dobri trikovi” koji obećavaju pogled odasvud i niotkud, jednako i potpuno, no upravo je $\mathrm{u}$ epistemologiji parcijalnih perspektiva mogućnost održivog, racionalnog i objektivnog istraživanja" (Haraway 1988: 584-585).

Kako bi se postigla parcijalna perspektiva koja vodi k objektivnom znanju Haraway predlaže koncept strasnog odvajanja. Strasno odvajanje zahtijeva mnogo više od osvještavanja i autokritike vlastite parcijalne pozicije. Kao strategija istraživanja, strasno odvajanje privilegira prijepore, dekonstrukciju, pasioniranu konstrukciju i analizu mreže odnosa (ibid.: 585). "Privilegiran pogled za feminističku epistemologiju znanstvene spoznaje ogleda se u razdvajanju [engl. splitting], a ne bivstvu. Odvajanje je u ovom kontekstu vezano za heterogene višestrukosti koje su simultano osnovica spoznaje i nemoguće ih je skupiti u izomorfni oblik ili kumulativne liste. Subjektivnost je višedimenzionalna, stoga je i svaki pogled višedimenzionalan. Spoznajno ja je parcijalno u svemu; njegov je oblik nezavršen, originalan u jednostavnosti bivanja tamo u tom trenutku, uvijek konstruiran i spojen nesavršenim šavovima, stoga i u mogućnosti da se pridruži drugome, kako bi zajedno vidjeli, a da pritom ne mora tvrditi da je to drugo" (ibid.: 586). Višestrukosti se nalaze u nama samima i susrećemo ih na terenu. Haraway podsjeća na Teresu de Lauretis (1986), koja zagovara osvještavanje različitosti među ženama kao različitosti unutar nas/njih samih. Jednom kada prihvatimo da upravo te razlike konstituiraju svijest i subjektivne limite svake žene, shvatit ćemo da upravo one, u svojoj specifičnosti, definiraju ženski subjekt feminizma i da kao takve ne mogu biti smještene u fiksirane/čvrste identitete (Haraway 1988: 586).

Terenskom sam istraživanju prišla, dakle, kroz okvir teorije situiranog znanja; prema tom ključu sam "birala" sugovornike, provodila razgovore, promatrala i sudjelovala. Istu sam teoriju odlučila koristiti u interpretaciji dobivenih rezultata. 
Međutim, nedostajao mi je alat kojim bih analizirala rezultate dobivene terenskim radom i kritičkim čitanjem povijesnih (primarnih i sekundarnih) izvora. Prihvatila sam i obuhvatila višeglasje subjekta, heterogenost iskustava i višedimenzionalne poglede (moje i one subjekata istraživanja), ali da bih ponudila odgovore istraživačkim pitanjima, odnosno potvrdila hipoteze, bilo je potrebno ustvrditi što je zajedničko tim višeglasjima, a koje su njihove distinktivne karakteristike. Činjenica je da su radnice, ali i osobe koje su govorile o svom društvenom sjećanju na radnice, pokazivale relativno jasne i ponavljajuće "obrasce različitosti” te da je u samoj fazi istraživanja bilo jasno kako različita kombinacija identiteta tvori različite obrasce opresije ili privilegije. Za analitički se okvir logički nametnuo intersekcionalizam kao jedna od metodologija, ali i jedan od teorijskih okvira za promišljanje presijecanja identiteta kao uzroka segregacije i razvoja hegemonijskih odnosa. Haraway već 1985. godine upućuje na intersekciju perspektiva zagovarajući teoriju afiniteta (Haraway 1985: 73) koja bi kombinirala epistemološke perspektive. Međutim, najiscrpnije radove na polju intersekcionalizma, kao i sam naziv teorijskog i metodološkog usmjerenja, donosi Kimberle Crenshaw ${ }^{38}$ (1989).

\section{3. Intersekcionalizam}

Crenshaw 1989. godine objavljuje utjecajan rad "Demarginalizing the Intersection of Race and Sex: A Black Feminist Critique of Antidiscrimination Doctrine, Feminist Theory and Antiracist Politics". U radu predstavlja problematične posljedice sklonosti da se rasa i rod tretiraju kao uzajamno isključive kategorije iskustva i analize. Svoju je analizu temeljila na usporedbi i sučeljavanju višedimenzionalnih iskustava crnkinja u odnosu na jednoosnu analizu koja iskrivljuje ta iskustva. Najčešća lingvistička manifestacija te jednoosne analize reflektirana je u konvencionalnoj uporabi termina "blacks/crnci” i “žene”. Na danom primjeru, Crenshaw plastično objašnjava kako je moguće da će neki ljudi uključiti crnkinje u jedan ili drugi termin, ali da kontekst u kojem se navedeni termini koriste sugerira isključenost crnkinja iz navedenih termina jer se one ne uklapaju ni u kategoriju muških crnaca ni onu bijelih žena. Fokus

\footnotetext{
${ }^{38}$ Američka odvjetnica koja putem vlastite prakse osvještava dodatnu opresiju nad crnim ženama u odnosu na bjelkinje i razvija teoriju intersekcionalizma.
} 
na privilegiranije članove društva (u ovom slučaju muškarac ili bijela žena) marginalizira one koji su višestruko opterećeni (crna žena), onemogućavajući im time (i) potvrdu diskriminacije (Crenshaw 1989: 139). Kao konkretan primjer nemogućnosti potvrđivanja diskriminacije Crenshaw navodi parnicu koju je pokrenulo pet crnih radnica protiv tvrtke General Motors. Radnice su tvrdile da sustav radnog staža (koji je podrazumijevao da otkaz dobivaju oni koji su najkraće zaposleni) perpetuira efekte prošlih diskriminatornih praksi. Naime, General Motors do 1964. godine, kada se usvaja Zakon o građanskim pravima, nije zapošljavao crnkinje, a temeljem spomenutog sustava radnog staža, u periodu recesije prve su dobile otkaz žene zaposlene nakon 1970. Tužilac je tužbu prvi put temeljio na specifičnoj situaciji crnkinja, dakle ne crnaca ili žena. Međutim, sud je odbio tužbu argumentom da crnkinje ne predstavljaju posebnu klasu te da je General Motors dokazao da je i prije 1964. godine zapošljavao žene dakako bjelkinje -i crnce -dakako muškarce. Crenshaw zaključuje kako su crnkinje mogle biti zaštićene samo ako je njihovo iskustvo odgovaralo jednoj od dviju kategorija [muškarac crnac ili bijela žena] (ibid.: 142-143).

Navedeni primjer upućuje na to da se razlike unutar feminističko-antropološkog pristupa ne mogu više temeljiti isključivo na binarnim opozicijama i rodnoj dihotomiji, već na mreži kompleksnih odnosa koje stvaraju isprepleteni rodni, rasni, nacionalni, klasni i drugi identiteti. Preuzevši kritiku feminističke teorije od ranijih feministkinja, poput Hill Collins, koje su isticale da su crnkinje (ili domorotkinje različitih kultura) isključene iz feminističke teorije, Crenshaw ide korak dalje i ističe da su one isključene i iz antirasističkih diskursa iz razloga što oba diskursa predviđaju izolirani set iskustava koji uglavnom ne reflektira interakciju rase i roda (ibid.: 140). Važno je pritom spomenuti da je Crenshaw svjesna kritike identitetskih politika. Nije joj bila namjera intersekcionalizmom ponuditi još jedan vid totalizirajuće identitetske politike (ibid.). Naprotiv, na tragu Haraway, smatra da identitetske politike ne samo da ne uspijevaju nadići različitost kao danost nego i ignoriraju unutargrupne razlike (Crenshaw 1991: 1242).

Inspirirana intersekcionalizmom kao teorijskim alatom, sagledala sam načine na koje višestruki identiteti rovinjskih radnica utječu na njihove uloge i poziciju u društvu. 
Stoga neću govoriti o ulozi i poziciji radnica, nego o ulogama i pozicijama radnica $u$ dva industrijska pogona. Dobar primjer za primjenu intersekcionalizma u ovom radu pruža sljedeći iskaz moje sugovornice:

Mamin je san bio raditi u Tvornici duhana, ali nije bila upisana u fascio, ${ }^{39}$ a i kao Slavenki su joj vrata Tvornice duhana bila zatvorena. Zbog toga je počela raditi u Ampelei, današnjoj Mirni, gdje je ostala do 1948. godine. Tek joj se tada otvorila mogućnost prelaska u Tvornicu duhana Rovinj (A. D. Q).

Posebno je zanimljivo kako se privilegirana pozicija na primjeru Rovinja mijenjala ovisno o društveno-političkim okolnostima. Iz navedenog je citata vidljivo da je radnica o kojoj je riječ trpjela otvorenu diskriminaciju kao apolitična Slavenka ${ }^{40}$ iz obližnjeg sela. Za vrijeme Kraljevine Italije njezin slavenski identitet i nepripadnost fašističkom pokretu svrstavali su je u drugorazrednu radnicu (a da pritom još nismo uzeli u obzir rodnu intersekciju koja je postavlja u još težu društvenu poziciju, odnosno multiplicira njezin ionako višedimenzionalan identitet), dok, vidjet ćemo i u kasnijim analizama, promjenom vlasti, njezino podrijetlo postaje ako ne poželjno, onda barem prihvatljivo. No što se tada događa s, primjerice, siromašnim radnicama talijanskog podrijetla koje su ujedno pripadnice fašističkog pokreta?

Za naš je rad posebno zanimljiva intersekcija rodnih, klasnih i nacionalnih identiteta. Žene radnice su bile isključene iz klasnog diskursa sve do poslije Drugog svjetskog rata, kada njihovo javno "uvođenje" u radnički pokret ima specifičnu funkciju usmjerenu na podizanje urušenih ekonomija i stvaranje nadnacionalnih identiteta temeljenih na ideji bratstva i jedinstva. Istinska briga za društvenu jednakost nije bila

\footnotetext{
${ }^{39}$ Nije bila članica fašističkog pokreta.

40 Temeljeno na uvjerenju da osoba sama definira ili ne definira svoj nacionalni, narodni ili regionalni identitet, kroz disertaciju ću navedene oznake pripadnosti ostavljati u originalu. Trudit ću se pritom objasniti iz vlastitog ugla, a s nadom da djelomično prenosim i osjećaje pripadnosti kazivača, na što se točno određeni termini odnose. Autohtono rovinjsko stanovništvo čine Latini, romansko stanovništvo koje na tom uskom prostoru uz more obitava najkasnije od 5 st. n. e, kako se spominje u djelu Cosmographia ravenskog Anonimusa. Unatoč napadima Saracena i Slavena te vlasti Langobarda, a kasnije i petostoljetnoj vladavini Venecije, dio stanovništva je do danas zadržao istriotski jezik (latinska vulgata), koji upućuje na njihovo podrijetlo. Slaveni se u nekoliko navrata, zajedno s drugim kolonima, nastanjuju diljem Istre, pa tako i u Rovinjskom Selu i drugim selima nadomak Rovinja. Unatoč stoljetnom suživotu bez većih zabilježenih sukoba na lokalnoj razini, za Rovinjce su Seljani (stanovnici Rovinjskog Sela) uvijek bili Slavi (dakle, ne Hrvati, Srbi, Slovenci, kako su se kasnije neki od stanovnika izjašnjavali), a za Seljane su Rovinjci bili Latini (ne Talijani, kako bi mnogi pomislili). Takve su se identitetske oznake zadržale do danas. Nerijetko sam i sama doživljavala da me prijatelji iz Rovinjskog Sela nazivaju Latinkom. Također, vrlo je često isticanje regionalnog identiteta; pa ako za sebe neće reći da su Slaveni, onda će se stanovnici obližnjih sela identificirati kao Istrijani.
} 
temelj tadašnjeg isticanja doprinosa radnica cjelokupnom društvu. Ako preslikamo našu situaciju na primjer koji je Crenshaw koristila kako bi objasnila primjenu intersekcionalizma, mogli bismo reći sljedeće: lingvistička manifestacija jednoosne analize reflektirana je u konvencionalnoj uporabi termina "radnička klasa" i "Talijani/Slaveni”. U takvoj će se analizi uključiti radnice (jedne od navedenih nacionalnosti) u jedan ili drugi termin, odnosno bit će ili dio radničke klase ili Talijanke ili Slavenke, ali će im se zanijekati mogućnost da istodobno pripadaju objema kategorijama. S obzirom na to da je ljudsko iskustvo složenije od zbira, u našem primjeru, roda i nacionalnosti, svaka analiza koja ne uključuje intersekcionalnost teško da može zadovoljavajuće artikulirati specifičan način na koji su crnkinje [u našem primjeru žene radnice - Slavenke/Talijanke ili druge nacionalnosti] subordinirane (ibid.).

Crenshaw svoj najveći doprinos daje u artikulaciji intersekcije rodnih i rasnih identiteta, međutim, to nas ne smije odvratiti od primjene teorije na sve moguće opresivne situacije. Primijetit ćemo, primjerice, kako se intersekcije rase i roda nerijetko realiziraju upravo unutar radničkog konteksta, uvodeći u jednadžbu i treći faktor -klasu. U knjizi Mapping the Margins (1991) Crenshaw baca još snažnije svjetlo na kompleksnosti intersekcionalizma. Kroz ideju strukturalnog intersekcionalizma ističe na koje se načine kućno nasilje nad crnkinjama, zajedno s procesima oporavka, kvalitativno razlikuje od onog nad bjelkinjama, a kroz politički intersekcionalizam ukazuje na to da su i feminizam i antirasistički pokreti, paradoksalno, često jačali marginalnost pitanja nasilja nad crnkinjama te, konačno, u posljednjem poglavlju uvodi koncept reprezentacijskog intersekcionalizma. Pod tim podrazumijeva kulturne konstrukte o crnkinjama koji, između ostalog, nastaju i kroz reprezentacije crnkinja u popularnoj kulturi, a koji mogu biti snažan izvor intersekcijskog onemoćenja ${ }^{41}$ (Crenshaw 1991: 1285). Na sličan način rovinjski imaginarij o radništvu, razvijan rekuperacijom i dekontekstualiziranim korištenjem folklorne građe i devetnaeststoljetnim povijesnim prikazima, onemoćava poziciju (nekih) radnica, s

\footnotetext{
${ }^{41}$ Pod intersekcijskim onemoćenjem Crenshaw podrazumijeva stereotipne reprezentacije marginalnih grupa u javnosti, posebno u popularnoj kulturi, koje, ako propustimo artikulirati specifičnu žensku poziciju, mogu postati dodatni izvor opresije (Crenshaw 1991: 1245).
} 
obzirom na kulturne konstrukte koji ih (generalizirano) projiciraju kao bogate i samosvjesne žene slobodnijih manira.

Teorijske postavke Kimberle Crenshaw omogućit će razotkrivanje bezbroj kombinacija identitetskih intersekcija, pa će primjerice Browne i Misra (2003) koristiti intersekcionalizam kako bi istraživali segregaciju na tržištu rada, dok će Parent i suradnici (2018) teoriju koristiti u istraživanju muškog mentalnog zdravlja, konkretnije osoba za koje je vjerojatnije da će tražiti pomoć uslijed mentalnih oboljenja. Primjene su veoma različite, a korisnost teorije dokaziva je i temeljem razvijenog metodološkog aparata. Setareh Rouhani (2014) donosi vodič za kvantitativnu intersekcijsku metodu koja kroz analizu statističkih podataka omogućava artikulaciju kompleksnih odnosa uzajamno konstituirajućih faktora društvene lokacije i strukturne opresije (Rouhani 2014: 4). Ista autorica s pravom ističe kako kvalitativno istraživanje omogućava bolje razumijevanje življenih iskustava i kompleksnosti nejednakosti te se u zaključku zalaže za kombinaciju metoda (ibid.: 15). O kompatibilnosti metoda o kojima je bila riječ u drugom poglavlju i intersekcionalizma kao analitičkog okvira istraživanja, najbolje govori Vodič za kvalitativno-intersekcijsko istraživanje koji potpisuje Gemma Hunting. Hunting ističe kako intersekcionalizam i kvalitativna metodologija (primjerice etnografija) dijele pretpostavku o važnosti isticanja istraživačkog konteksta, stavljanju pojedinačnih različitih glasova u prvi plan te nužnosti ukazivanja na neuravnotežene odnose moći između istraživača i subjekata istraživanja (Hunting 2014: 1). Vodič donosi pregled cjelokupnog istraživačkog procesa od pripreme terena do provedbe intervjua, analize i raspisivanja rezultata. Dio postupaka pratit ćemo i u našoj analizi te ćemo se tada detaljno vraćati na pojedinačne korake. Sada je oportuno zaključiti kako je u intersekcijskom istraživanju važno odmaknuti se od demografije i ostvariti širi fokus na svakodnevna iskustva (primjerice stres, stigme, diskriminaciju i dr.), što će Hunting, slijedeći Christensena i Jensena (2012), nazvati "svakodnevicom kao mjestom polaska" (ibid.: 12). 


\section{4. Industrijska antropologija}

Mjesto polaska našeg istraživanja industrijski je rad iz perspektive njegovih glavnih akterki - radnica. Ako smo dosad govorili o važnosti feminističkog pristupa u sagledavanju heterogenih ženskih iskustava i ispresijecanih višedimenzionalnih identiteta, vrijeme je da se fokus sa ženskog iskustva na trenutak suzi na domenu ženskog industrijskog (radničkog) iskustva. Na koji je način industrijska antropologija artikulirala poziciju radnica u odnosu na šire društvene pokrete? Koja je specifičnost industrijske antropologije u pogledu subjekta i metode istraživanja? I konačno, koji je odnos feminizma i industrije ili roda i rada?

Kao što feministička antropologija svojim teorijskim, metodološkim i epistemološkim uvidima nadopunjuje feminizam kao društveni pokret artikulirajući žensku poziciju u antropološkim istraživanjima, tako se i industrijska antropologija posvetila istraživanju industrijskog rada kao jedne od revolucionarnijih promjena ljudskog roda u širem ekonomskom smislu. Industrijska revolucija započinje u 18. stoljeću, a antropologija vrlo brzo po svom nastanku, već sredinom 20. stoljeća, uočava nužnost sagledavanja radničke klase kao subjekta istraživanja, što govori u prilog avangardnosti i relevantnosti discipline. Dotad se antropologija bavila predindustrijskom ekonomijom.

Industrijska se antropologija razvija u okviru ekonomske antropologije kao poddiscipline antropologije. U općim crtama, ekonomsku antropologiju bismo mogli definirati kao poddisciplinu koja proučava i objašnjava sustave unutar kojih ljudi podmiruju potrebu za materijalnim; način proizvodnje, distribucije i potrošnje. Posebno se fokusira na organizaciju sustava, model njihova funkcioniranja, odnos s drugim sustavima, načine na koje ljudi unutar ekonomskih sustava odlučuju i posljedice njihovih odluka. Jedan od ključnih ciljeva ekonomske antropologije je opisati te procese $\mathrm{u}$ lokalno smislenom kontekstu koji bi reflektirao univerzalnu relevantnost (Durrenberger 2005: 125). U konceptualnom se smislu fokus ekonomske antropologije temeljio na nekoliko ključnih tema: razmjeni, daru, vlasništvu i radu. Koncept razmjene, posebno darova $\mathrm{i}$ nenovčanih, pa čak i nematerijalnih vrijednosti, povezuje se $\mathrm{s}$ predindustrijskim ekonomijama. Vlasništvo predstavlja prvu nišu unutar koje se 
sagledava uloga i pozicija žena u ekonomskim sustavima (pri čemu su Marx i Engels najznačajniji autori na koje se takve analize referiraju), a tek se kasnih 1970-ih žena uključuje u znanstvena promišljanja rada, doživljavajući svojevrsni boom u analizama industrijskog (Treći svijet) i postindustrijskog rada od 1990-ih naovamo. Nas će posebno zanimati pitanje vlasništva i rada u kontekstu industrijskog ekonomskog sustava s time što ćemo se, temeljem opisane metodologije, neprestano kretati između različitih vremenskih odrednica ukazujući i na predindustrijske karakteristike ženskog vlasništva i rada u Rovinju u usporedbi s drugim usporedivim zajednicama i društvenopolitičkim odrednicama (Austro-Ugarska i Italija). Posebno je važno ukazati na činjenicu da se sve što su rovinjske radnice doživljavale prije više od stotinu godina u antropološkom diskursu javlja tek krajem 20. stoljeća, i to kroz primjere analize suvremenih radničkih praksi (dakle od 1950-ih naovamo), a pod utjecajem feminizma. Već nas ova konstatacija dovodi bliže dokazivanju nevidljivosti žena unutar strogo određenih granica radničke klase. Rana industrijalizacija nije obuhvaćena $u$ antropološkim radovima vjerojatno zbog nemogućnosti (direktne) primjene etnografske metode polustrukturiranog intervjua i promatranja sa sudjelovanjem. Upravo su zato interdisciplinarnost i kreativnost u smislu teorijskog i metodološkog okvira ključne za ovaj rad. Ekonomska, odnosno industrijska antropologija otvara nam mogućnost istraživanja specifičnih organizacija rada, a feminizam nam daje alate za razumijevanje ženskog iskustva unutar tih organizacijskih sustava.

Dva su temeljna pristupa unutar ekonomske antropologije: substantivizam i formalizam. Karl Polanyi (1886.-1964.) jedan je od najutjecajnijih ekonomskih antropologa substantivističke orijentacije. Na njegov je rad snažno utjecao Malinowski, posebno zbog svog fokusa na gospodarski aspekt trobriandskih zajednica, koji ima dublje simboličko značenje i ukorijenjenost u vlastitu kulturu. Naime, Polanyijev substantivizam karakterizira kritika kapitalizma kao ekonomije odvojene od socijalnog konteksta. Polany tumači da sve ekonomije imaju sustav distribucije, no pritom je jedino onaj kapitalistički primarno integriran u društvo kroz razmjenu na temelju cijena, dok su ranije ekonomije bile integrirane kroz koncept reciprociteta i redistribucije. Fokus substantivističke grupe je na istraživanju predindustrijskih društava s ciljem promoviranja koncepta u kojem je ekonomija ponajprije odnos čovjeka, prirode i 
zajednice. Stoga je glavna poruka substantivista da se ekonomija ne može sagledati samo na razini tržišta, već u suodnosu s kulturnim i društvenim faktorima koji je oblikuju.

Suprotno tome, formalisti ekonomiju razumiju kao način uporabe sredstava dostupnih za život, dakle kroz ideju ekonomizacije (Isaac 2005: 14-15). Škola formalista nastaje 1966. godine kao protuodgovor substantivistima, s dva temeljna argumenta:

1. Mikroekonomski modeli ne mogu biti primijenjeni univerzalno; ${ }^{42}$

2. Ekonomska se antropologija više ne bavi primarno ekonomijama “primitivnih" ili "arhaičnih" društava na koja je substantivistička metodologija jedino primjenjiva (ibid.: 18). Formalisti su svoja istraživanja fokusirali na individualni izbor, stoga je njihov metodološki pristup individualistički, dok substantivisti istraživanja shvaćaju kroz institucionalne matrice unutar kojih se stvara izbor (ibid.: 19). Isaac će reći da substantivističko-formalističkoj debati nema kraja jer nijedna od tenzija među školama ne može biti riješena osim u odnosu na specifične istraživačke probleme ili kroz pitanje osobne preferencije (ibid.: 20). Unatoč kasnijem "porazu” substantivističke ideje, utjecaj Karla Polanyija i danas je prisutan, posebno kada je riječ o konceptima reciprociteta i redistribucije, koji postaju dio antropološkog teorijskog nasljeđa (ibid.: 22).

Predindustrijske zajednice organizirane su na temelju zadataka i usklađene su s ritmom prirode. Industrijom vlada apstraktni sat koji nameće novu radnu disciplinu i, kako će Jonathan Parry istaći, stvara novu podjelu, onu na "rad” i "život” (Parry 2005: 142). Istraživanja odnosa muškaraca i žena unutar industrijskih društava temelj nalaze upravo $u$ toj podjeli. Parry iznosi (neargumentiranu) teoriju o progresivnom opadanju potražnje za ženskom i dječjom radnom snagom, što industriju svodi na dominantno mušku sferu ostavljajući ženama domenu kućanstva (ibid.). Znamo li da su žene u duhanskoj industriji (jednoj od najvećih, najsnažnijih i najprofitabilnijih) na širem geografskom području (Austro-Ugarska) činile često i do $90 \%$ radne snage, pitanje je kako je takva interpretacija moguća. Analizom ćemo pokazati da je ta dihotomija

\footnotetext{
${ }^{42}$ Feministička ekonomija i antropologija dodatno su kritizirale mikroekonomski model i Polanyijevu
} podjelu na "kućanstvo" i "ekonomiju” (Stivens 2005: 324 prema Ferber i Nelson 2003). 
neodrživa i artificijelna, utemeljena na perpetuiranju rodno stereotipnih uloga, koje za cilj ima održavanje odnosa moći.

Temelje industrijske antropologije dao je Elton Mayo kroz Školu ljudskih odnosa, u čijem je centru "humanistička" dimenzija rada. Naime, Mayo je zagovarao istraživanja temeljena na solidarnosti radničke klase prema kojima je radnike sagledavao izvan opće pesimistične slike mehaniziranog rada, odnosno mehaniziranog čovjeka. Michael Burawoy detektira da je Mayo, preuzimajući teorijske postavke Durkheima, Pareta, Malinowskog i Warnera, ciljao na preslikavanje ekonomije solidarnosti predindustrijskih zajednica na industrijsku realnost, koja bi u konačnici vidjela radnike ujedinjene u ostvarivanju zajedničkog cilja. Osnovna kritika takvog pogleda temelji se na njegovoj nesposobnosti artikulacije različitih interesa ne samo među radnicima i upravom nego i unutar kolektiva. Uslijed velike ekonomske krize javljaju se kritike Mayove Škole ljudskih odnosa. Warner i Low (1947) izvor industrijskog konflikta pripisuju gubitku kontrole nad proizvodnim procesima te prebacivanju fokusa s radničkih vještina na kapital. Drugi odgovor na Školu ljudskih odnosa, primjerice onaj Joan Woodward, ističe razvoj tehnologije kao faktor koji onemogućava dotadašnju superviziju rada na temelju osobne kontrole i fokusira se na sagledavanje ograničenja koje donosi mehanizacija. Treći odgovor ${ }^{43}$ na Mayove humanističke ideje su istraživanja koja se fokusiraju na upravljačke strukture. Nova istraživanja uviđaju, a samim time i artikuliraju razlike unutar upravljačkih struktura kao i nestabilnost heterogene okoline, posebice u promijenjenim društvenim i tržišnim odnosima, što je suprotno tezama Mayoa, koji je upravljačke strukture (u konačnici i cjelokupne radničke kolektive, odnosno industriju kao tip ekonomske organizacije) promatrao kao homogene sustave koji su izolirani i različiti od radničkih grupa. Pritom, Burawoy smatra da je "težnja ahistoričnoj generalizaciji koja bi odgovarala svim ekonomskim organizacijama ostavila po strani realni život, a industrijska je antropologija takvom orijentacijom iščezla u kaosu apstraktnih kategorija" (Burawoy 1979: 232-238). Naime, istraživanje usmjereno na organizacije u općem smislu, uključujući primjerice organizaciju unutar bolnice ili policijske postaje, u industrijsku antropologiju unosi bojazan gubitka subjekta istraživanja, podsjećajući pritom na "krizu

\footnotetext{
${ }^{43}$ Primjerice u radovima March i Simon (1958) ili Thompson (1967).
} 
gubitka feminističkog subjekta". U svakom slučaju, ono što je karakteriziralo postmayovsku industrijsku antropologiju, a što je i orijentacija ovog rada, jest konačna svijest o povijesnoj i geografskoj specifičnosti (industrijskog) rada, koju je valjalo inkorporirati u buduća istraživanja (ibid.: 233).

Austrijski i talijanski monopol rovinjskih tvornica razlikovao se od jugoslavenskog koncepta samoupravljanja. Utjecaj političkih okolnosti na ekonomiju snažno odjekuje unutar obitelji, u obrazovanju, na individualnoj razini i u svakodnevici oblikovanoj novim vrijednostima. Slijedeći kritiku Eltona Maya u kontekstu industrijske antropologije koja iziskuje istraživanje unutar specifičnog geografskog i povijesnog konteksta, industrijsko-antropološko očište povezano je $\mathrm{s}$ teorijom situiranog znanja te je stoga subjekt ovog rada smješten kroz tri društveno-politička sustava s očiglednim reperkusijama na industrijsku organizaciju i radničke uloge.

Razvoj industrijsko-antropološke teorije omogućio je da se industrijski rad počinje promatrati kroz prizmu nejednakosti, međusobnih natjecanja i konflikata, a koji nastaju među ekonomski racionalnim individuama ${ }^{44}$ (ibid.: 235). Burawoy će zaključiti da natjecateljski duh među radnicima i borba među klasama može biti uzrok i posljedica poništavanja radničkih vještina. Borba je, pritom, oblikovana kroz organizaciju rada, mobilnost kapitala te (nesigurnost) tržišta (ibid.: 242). Želeći jasnije strukturirati i omogućiti analizu takvih odnosa Burawoy predlaže distinkciju kompetitivnog i monopolističkog kapitalizma. Tvornice koje su temelj istraživanja ovog rada su Tvornica duhana Rovinj (TDR) i Tvornica za preradu ribe Ampelea, kasnije Mirna. Te su tvornice do razdoblja poslije Drugog svjetskog rata, kada prelaze na socijalistički ekonomski model radničkog samoupravljanja, iskazivale karakteristike obaju modela kapitalizma. Za razliku od kompetitivnog, monopolistički model karakterizira određena sigurnost radnika kroz instituciju minimalne plaće i svojevrsnu kontrolu koju radnici imaju nad procesom proizvodnje. Način na koji se ta kontrola stječe nije posebno

\footnotetext{
${ }^{44}$ Ističu se racionalni radnici nasuprot iracionalnom menadžmentu. Burawoy navodi primjere proizašle iz doktorske disertacije D. Roya Restriction of Output in a Piecework Machine Shop (1952). Radnici su u jednom slučaju odbili dostići dnevnu kvotu s obzirom na nemogućnost realizacije plaće po proizvedenom komadu i zadovoljili se minimalnom plaćom, dok su u drugom slučaju radnici dosegli dobro poznati limit do kojega je bilo moguće doći, a da uprava ne bi spustila cijenu po komadu. Roy navodi kako je racionalni moment kod radnika utemeljen u prisustvu nadglednika koji su, skrivajući se po hodnicima, štopericom mjerili vrijeme potrebno za proizvodnju robe (1979: 245-246).
} 
objašnjen, već se čini da Burawoy ${ }^{45}$ implicira prisutnost specifičnih radničkih kultura koje ili realiziraju ili ne realiziraju tu kontrolu, potencijalno temeljem kombinacije unutrašnjih (međuljudski odnosi, sigurnost ugovora, tip industrije) i još utjecajnijih, vanjskih (tržište, politička atmosfera) faktora (ibid.: 245-246).

TDR je odmah uspostavio monopolistički kapitalizam u okviru austrijskog duhanskog monopola. Ampelea se razvijala od kompetitivnog kapitalizma (najprije francuskog, zatim austrougarskog i konačno talijanskog) do socijalističkog samoupravljanja, preskočivši "Burawoyev" monopolistički kapitalizam. Analizom društveno-povijesnog, geografskog i političkog okruženja možemo uočiti da su se oba pogona, a time i kolektiva, razvijala u sličnim uvjetima. Različitost modela je stoga (jedino) moglo uzrokovati tržište. Duhansko je tržište bilo stabilno i profitabilno, ali, što je još važnije, održavalo se zahvaljujući sigurnoj opskrbi sirovim materijalom (duhanom). Najveća nedaća radnica riboprerađivačkih postrojenja bila je nesigurnost ulova. Ako tog dana, tjedna ili mjeseca nije bilo ribe, za radnice nije bilo ni posla, a time ni plaće. Takvo se stanje zadržalo do sredine 1950-ih godina, kada se unapređenjem tehnologije (prije svega uvođenjem hladnjaka) proces rada mogao predvidjeti i osigurati sirovinu za rad i u vrijeme slabijeg ulova. Tehnologija je značajno utjecala na položaj i uloge radnica, no u svakom pogonu na različite načine.

\section{5. Rod i rad}

They say it is love, we say it is unwaged work (Federici 1975: 1).

Kao uvod u analizu položaja i uloga rovinjskih radnica sagledat ćemo razvojnu putanju feminističko-antropoloških istraživanja pozicije žena u domeni rada. Pokušaj fokusiranog kronološkog pregleda ima za cilj ukazati s jedne strane na teorijsku

\footnotetext{
${ }^{45}$ Burawoy navodi i istraživanje T. Luptona u dvije manchesterske tvornice. U tvornici Wye radnici nisu imali kontrolu nad proizvodnim procesima ni sustavom individualnih stimulacija po proizvedenom komadu, dok su u tvornici Jay radnici bili kadri manipulirati proizvodnjom i shemom poticaja, dokazujući individualnu i kolektivnu kontrolu nad proizvodnjom i zaradom. Razlika je bila u tome što je tvornica Jay, poput našeg TDR-a (u ranim godinama), bila tvornica s jakim i stabilnim tržištem, niskom cijenom rada i visokom maržom, za razliku od Wye, u kojoj je cijena rada bila visoka, marže niske, a tržište nestabilno s obzirom na sezonalnost (naša Ampelea) i koncentraciju nekoliko sličnih tvornica na relativno uskom geografskom području (1979: 245-246).
} 
sofisticiranost koja se s vremenom gradi, a s druge na gotovo nepromijenjenu bit problema. Pritom ću se usredotočiti na tri teme koje smatram ključnima za razumijevanje daljnjih analiza:

- karakteristike i temeljne postavke teorija privatnog vlasništva koje predstavljaju jedan od prvih pokušaja sagledavanja mogućnosti i uvjeta ženske emancipacije,

- pitanje rada u domaćinstvu koji do danas nije izjednačen s plaćenim radom,

- ambivalentnost industrijalizacije u odnosu na žensku emancipaciju i nejednakost unutar radničke klase.

Pitanje privatnog vlasništva (stečenog nasljeđivanjem i samostalnim radom) ima snažan utjecaj na formiranje društvene uloge i pozicije rovinjskih radnica, dok je kućni rad temelj onoga što generalno (dakle, ne isključivo na istraživanom) možemo nazvati "nepotpunom ili nedovršenom emancipacijom".

Maila Stivens (v. Moore 1988) će reći da način na koji je antropologija (do pojave feminističke antropologije) sagledavala ekonomiju nije u zadovoljavajućem smislu uključivao žene, iako su one bile uključene u klasične ekonomsko-antropološke tekstove. Tomu je tako jer je disciplina dugo zadržala dihotomiju "ekonomije" na rad i "domaćinstvo" (ne-rad) (Stivens 2005: 323), a koja je direktno uvjetovala distinkciju na razini javno-privatno, odnosno društveno-osobno. Da bismo ilustrirali takva promišljanja koristit ćemo rad Aleksandre Muraj o zlarinskoj ženi. Prizivajući Braudela, Muraj svoj rad započinje tvrdnjom da je "prevladavajuće mišljenje da su žene mediteranskog kulturnog okružja zauzimale u društvu drugorazredni položaj. Isključene iz djelovanja u javnom životu mahom su bile potisnute na aktivnosti unutar prostora doma. Evidentnu vezanost žena mediteranskoga područja uz kuću Fernand Braudel smatra, štoviše, civilizacijskom činjenicom od posebnog značenja (1985: 205)" (Muraj 2004: 85). Primjećujemo da Braudel, kao i mnogi prije i poslije njega, ide korak dalje pa "privatnu" poziciju žena smatra civilizacijskim faktom. Iz ovakvih primjera uviđamo da je ekonomska tematika unutar antropologije i povijesti dominantnom maskulinom znanstvenom diskursu dala još više prostora za razvoj teza o prirodnoj subordiniranosti žena. Analizom ženske svakodnevice, Muraj ističe ambivalentnu poziciju zlarinske žene, koju interpretira dvojako. S jedne strane, mogućnost snažnije (od pretpostavljene) ženske pozicije Muraj vidi u činjenici da na Zlarinu vjerojatno nikada nije uspostavljen 
strogi patrijarhat (kao što je to bila situacija u Rovinju), te je stoga svijest o relativnoj neovisnosti žena stvar povijesnog trajanja. No Muraj nudi i drugu tezu prema kojoj "razborito ili ne" žene na Zlarinu, kao i druge žene na Mediteranu, potencijalno preferiraju privatnu nad javnom moći, odnosno „moć unutar kuće i obitelji” (ibid.: 94). Ovoj konstataciji vrijedi pridodati i specifičan rezultat istraživanja Rayne R. Reiter iz 1970-ih godina provedenog u jednom selu na jugu Francuske. Istraživačica navodi da su žene dominirale privatnom sferom te da su javnu, odnosno mušku sferu čak smatrale inferiornijom (Reiter 1975: 258). Ove tvrdnje možemo izazvati i ponuditi alternativno razmišljanje tek u suodnosu s drugim rezultatima i obuhvaćanjem društvenog konteksta u kojem se ovakvi rezultati generiraju.

Da je diljem Mediterana zaista na snazi "rodna geografija” tvrdi, dakle, i Rayna R. Reiter objašnjavajući da distinkciju na privatnu i javnu sferu generiraju načini korištenja prostora. Javna mjesta poput trga, lokalnog kafea ili ureda gradonačelnika domena su muškaraca, dok žene zauzimaju kućni prostor i uske skrivene uličice u stražnjem dijelu kuće (Reiter 1975: 256). Možemo postaviti jednostavno pitanje: zar muškarci ne borave u toj istoj kući? Kako je onda kuća ženska domena? Zaista je teško pomisliti da muškarac unutar četiri zida obiteljske kuće eventualno samo prespava i nešto pojede, bez ikakve primjedbe, onako kako žena brzim korakom prelazi javnim trgom, i to po mogućnosti kada muškarci nisu u selu (ibid.: 257), ili kojim slučajem uđe u općinski ured. Žene u istraživanom francuskom selu nemaju društvene, profesionalne i uopće veze izvan obitelji, a koje inače vladaju javnim prostorom koji je, kako smo vidjeli, pripisan muškarcima. One i ne mogu stvoriti takve veze zbog začaranog kruga privatno-javne, rodno označene dihotomije u kojem žive. One nemaju ni rječnik kojim bi opisale takve veze, a koncept klase im je ograničeno poznat.

U agrarnoj zajednici kakva je ona u kojoj je provedeno istraživanje posjed je iznimno važan, pa se pretpostavlja da bi žene koje u nasljedstvo dobiju zemlju ili je donesu u miraz mogle imale određenu moć. Međutim, u primjeru koji nam Reiter donosi to nije tako. Odricanjem od zemlje u korist muškaraca, posebno u javnom kontekstu, dakle vlasničko-pravnom, one takvu mogućnost otpora i kontrole predaju muškarcima. Reiter te odluke povezuje sa silnicama koje upravljaju javnim prostorom, 
a koje su ženama nedostupne i nepoznate. Naime, podaci o zemljištima, vlasnički listovi i druga administracija čuvaju se upravo u općinskim službama. Žene, dakle, nemaju pristup javnim informacijama ni vezama, one imaju samo očekivanja koja se pred njih postavljaju i bogat korpus znanja ograničen na obiteljska pitanja (ibid.: 265-267).

Nastojeći rastumačiti ovakve odnose, Reiter je posegnula za informacijama o ekonomskoj prošlosti žena u istraživanom selu kao i za usporedbom sa ženama koje u vrijeme istraživanja (1970. godine) rade za plaću izvan sela. Ustanovila je da je ženama zapravo postepeno oduzimana javna aktivnost pa posljedično i mogućnost zarade koju je ta aktivnost donosila. U konkretnom slučaju, to se odnosi na čišćenje tartufa koje je postepeno zamrlo, i u vrijeme kada Reiter provodi istraživanje više ne postoji ni jedna aktivnost u domaćinstvu koja bi mogla donijeti novac. U društvu koje se temelji na ekonomiji u novcu, takva situacija umanjuje društvenu moć i položaj žena te također služi održavanju razdvojenosti javnog i privatnog života (ibid.: 271). Međutim, ako su i $\mathrm{u}$ vrijeme rada za novac te dihotomije opstajale, pitanje je koliko je moguće u ovoj konkretnoj seoskoj zajednici odvojiti žene od privatne sfere kao njihove općeprihvaćene karakteristike i koliko ona ovisi o vlasništvu u novcu ako se novac stiče unutar poslova vezanih uz domaćinstvo (kao nadničarenje u polju, čišćenje tartufa unutar svog doma, čišćenje u tuđim domovima i sl.). Naime, u usporedbi sa ženama koje rade za plaću, ove žene nisu smatrale da rade iako su povremeno radile u trgovinama i kafeima ili su radile kao spremačice i njegovateljice u drugim kućama. Žene iz sela su se samodefinirale kao ne-radnice, a takvu ulogu su im pripisivali i muškarci. Definiranje žena koje obavljaju gotovo jednake poslove kao i muškarci (u polju primjerice, a vidjeli smo i šire) kao neradnica potiče njihovu ekskluziju i izostanak iz javnog života uopće (ibid.). Takvo definiranje ženskog rada potencijalno stvara i značajne razlike među ženama (koje rade za plaću javno, primjerice u nekoj industriji, nasuprot onima koje uslugu rada obavljaju u sivoj ekonomskoj zoni poput čuvanja djece ili čišćenja domova), a svakako djelomično može poslužiti kao protuteza konstataciji o svojevoljnoj ekskluziji iz društvenog prostora (na Zlarinu isto kao i na jugu Francuske). Zbog činjenica da su perpetuirano i konstantno marginalizirane i da im informacije nisu dostupne, žene kreiraju svojevrsnu samoobranu, stvarajući “prostor" u kojem su sigurne i u kojem bar prividno imaju određenu vrstu moći. 
Puno prije feminističke antropologije i feminističke ekonomije, u formativnom periodu feminizma, među brojnim intelektualkama, djeluje književnica i društvena reformatorica Charlotte Perkins Gilman, ${ }^{46}$ koja 1898. godine objavljuje knjigu Women and Economics: A Study of the Economic Relation Between Men and Women as a Factor in Social Relationship. Djelo reflektira društvene i tehnološke promjene kojima je autorica svjedočila uslijed snažnog industrijskog razvoja rodnog Connecticuta. Gilman je u svojim autobiografskim radovima isticala nužnost ekonomske stabilnosti žena koja bi ih oslobodila kućanstva i opresije, a vrlo napredno govori i o ograničenoj mogućnosti djelovanja za sve žene koje ne rade izvan domaćinstva, a što utječe i na razboritost, snagu i želju za odlučivanjem. Već u samom predgovoru Women and Economics, Gilman najavljuje za tadašnje vrijeme iznimnu osviještenost o konceptu roda kao društvene kategorije koju kasnije razvija na temelju usporedbe sa životinjskim svijetom (Gilman 2012: 17): “[P]okazat ću su kako neka od najgorih zala zbog kojih patimo i za koja odavno (oduvijek) mislimo da su inherentna i ukorijenjena u našoj prirodi, nisu ništa drugo doli proizvoljna stanja prihvaćena od nas samih" (ibid.: 1).

Razlozi takvog prihvaćanja, prema Gilman, leže u zakonu o prilagodbi koji organizme nepopustljivo smješta u okolinu. Sama je to slikovito objasnila: "Osobe postaju neosjetljive na redovite i konstante podražaje, reagirajući samo pod iznimnim okolnostima; slično kao što otkucaji sata, curenje vode iz slavine, šum valova na plaži, pa čak i kaotični zvuk jurećeg vlaka prolaze neprimijećeno za osobe koje ih čuju konstantno" (ibid.: 26). Drugi razlog prihvaćanja opresije Gilman objašnjava lakoćom stvaranja osobne impresije nasuprot mogućnosti generalizacije. Moć opažanja i stvaranja osobne impresije, reći će Gilman, pokazuje nižu razinu razvoja u odnosu na sposobnost kategorizacije, usporedbe i stvaranja općeg mišljenja o određenom fenomenu (ibid.: 26-28). Bez mogućnosti saznavanja, žene su osuđene na opresiju. S obzirom na to da u vrijeme u kojemu je pisana njezina knjiga tekovine industrije još nisu zahvatile sve žene, Gilman će, koristeći logiku zakona prilagodbe, položaj žena prije industrijalizacije tumačiti uvjetovanošću ekonomskim pritiscima. Ilustrirajući

\footnotetext{
${ }^{46}$ Gilman nije bila visokoobrazovana, ali je svojim trudom i čitanjem, te uz poticaj daljnjih rođakinja, abolicionistkinja, od najranije dobi zagovarala jednakost žena u društvu. Jedna je od prvih koja je tu jednakost vidjela mogućom samo ako žene steknu ekonomsku neovisnost. Nakon što joj je prepisano mirovanje (čitaj zabrana intelektualnog rada i fokus na kućanske poslove) kao terapija za postporođajnu depresiju, Gilman je pobjegla s kćerkom u Kaliforniju, gdje je na temelju vlastitog iskustva zagovarala pravo žena na rad i samostalnost (predgovor: Asta u Gilman 1898 (2012)).
} 
perpetuaciju ženskih nedaća kroz povijest kroz odnos majke-kćeri u kojem majka ne upućuje svoju djecu u majčinstvo sa svim teškoćama koje ono nosi, Gilman u svojoj maniri ponovno ukazuje na probleme ponavljajućih akcija i odvojenosti žene od rasuđivanja za sebe. Zašto je tome tako? Gilman neće pogrdno reći da žene nisu sposobne rasuđivati, one su ekonomski ucijenjene. "Djevojka se mora udati. Kako li će inače živjeti? Potencijalni supružnik preferira da djevojka ne zna ništa. On je tržište, on potražuje. Ona je nudi" (ibid.: 29). Rješenje ovakve pozicije žena Gilman vidi u procesima industrijalizacije. Žene su u vrijeme nastanka njezine knjige prisutne $\mathrm{u}$ gotovo svakoj industrijskoj grani te, iako i dalje rade samo zato što moraju i to uglavnom sve dok se ne udaju, postepeno se sve više njih osamostaljuje. Promjena je, prema Gilman, bila vidljiva i prije svega se ogledala u društvenom statusu žena radnica. Nadahnuta romantičarskom vizijom industrijskog razvoja, koja predstavlja glavni temelj za kritiku njezina rada, autorica industriju tumači kao ono što održava na životu. Sve edukacijske, religijske i dobrotvorne organizacije koje služe višim ljudskim ciljevima konstituiraju tu aktivnost (industriju), omogućavajući ženama participaciju u društvenom životu (ibid.: 49-53).

Kao sastavni dio procesa koji možemo nazvati “ženskom” stranom industrijalizacije, iz razloga što ne pogađa na isti način muškarce, Gilman će već tada iznijeti lucidnu analizu kućanskih poslova koji bi trebali biti jednako vrednovani kao javni rad. U svojoj analizi dekonstrukcijom dolazi do zaključka da su žene robinje vlastitih muževa i da žene koje nisu majke, prema tadašnjoj logici razumijevanja vrijednosti ženskog rada, zapravo nemaju nikakvu ekonomsku vrijednost (ibid.: 3-5). Primjer nejednakog društvenog statusa (klase) pekara i žene koja u domaćinstvu svakodnevno proizvodi kruh (između ostalog) (ibid.: 22) izvrsno služi kao metafora za ono što će kasnije Silvia Federici (1975) nazvati ne-rad. Iako je Gilman bila priznata aktivistkinja i intelektualka i za života, njezine su radove ponovno otkrile feministkinje drugog vala 1960-ih godina, a kasnije i feminističke antropologinje. Jedna od prvih koja je reaktualizirala pitanje kućnog rada je spomenuta Silvia Federici (1975).

Kako bi demistificirala žensku ulogu u kapitalističkom društvu, Federici zagovara da se pitanje plaćenog kućnog rada promatra iz političke perspektive, a ne kao 
stvar, odnosno novac. Ona će reći kako je kapitalizam lukavom manipulacijom doveo do toga da je kućni rad naturaliziran i da se smatra inherentnim ženskoj prirodi, a s ciljem da se ni ne tretira kao rad te posljedično i ne bude plaćen. Ako kućni rad nije rad, za njega ne možeš dobiti plaću. Međutim, upravo je plaća ono što determinira radnika "imati plaću znači biti dio društvenog ugovora" (Federici 1975: 2). Da bi se takva subordinirana pozicija izmijenila, Federici promiče ideju plaćenog rada kroz dvije perspektive. Plaćanjem kućnog rada, rad postaje vidljiv. Jednom vidljiv, on postoji kao takav i omogućava izbor prihvaćanja ili odbijanja takvog rada (ibid.: 5). U svom nadahnutom aktivističkom tekstu Federici će zaključiti kako je jedino ovakav, radikalan potez moguć i nužan da bi se borba na ostalim "poljima nejednakosti” nastavila. Bez afirmacije kućnog rada kao rada, borba za bolje radne uvjete, jednake plaće, dnevnu skrb i drugo ostat će nerealizirana jer neće biti sveobuhvatna (ibid.: 6). Istaknut ću da je i za moju temu itekako važan element razumijevanje plaćenog rada (i kućnog) kao onog koji je nužno društveno valorizirati, odnosno kao onog koji osobu definira kao dio aktivnog društva. Upravo će se na tome temeljiti neke od narednih analiza.

Uz propitivanje kućnog rada, feministkinje se okreću i drugim aspektima poslovne sposobnosti žena, uvijek u dijalogu s drugim tezama o ženskoj opresiji. Početkom 1970-ih Alison Jaggar i Paula Rothenberg uređuju prvo izdanje zbornika radova Feminist Frameworks obilježenog jasnom uredničkom politikom i analizom autorskog dvojca. Drugo izdanje (1984), ${ }^{47}$ korišteno za potrebe ovog rada, unaprijeđeno je, prema riječima urednica, upravo zbog sve snažnijeg ekonomskog pritiska na žene (ibid.: XI). Jaggar i Rothenberg vlastitim uvidima i brojnim prilozima otvaraju polje za propitivanje nejednakosti unutar radničke klase temeljene na rodnoj distinkciji, primjerice pitanje uvjeta rada i jednake plaće za jednaki rad, s posebnim osvještavanjem heterogenih ženskih iskustava temeljem zahtjeva crnih feministkinja. Konceptualno zamišljen i formiran kao pregled analitičkih okvira, zbornik omogućava analizu pojedinih pitanja i opresivnih iskustava iz pozicije različitih teorija koje imaju za cilj poboljšanje društvenog statusa žena (ibid.: uvod XVI).

\footnotetext{
${ }^{47} \mathrm{https}$ //archive.org/details/feministframewor00mcgr, pristup 3. 11. 2017.
} 
U takvim promišljanjima neizbježna su pozivanja na Engelsa te analiza i kritika njegova rada. Engels je dao izniman doprinos u promišljanju ženske opresije kroz prizmu vlasništva i rada $\mathrm{u}$ djelu The Origin of the Family, Private Property and the State [Porijeklo obitelji, privatnog vlasništva i države] iz 1891. godine te se tako idealno uklapao u rastuće interese za sagledavanjem žena u odnosu na ekonomske organizacije. Engels tumači subordiniran položaj žena kroz ideju privatnog vlasništva. Njegova je pretpostavka da s razvojem patrijarhata (Engels 2004 [1891]: 66-67) dolazi do koncentracije vlasništva u muškim rukama. Kako u uvodu izdanja iz 2004. godine navodi Pat Brewer, ono što je za njegovo vrijeme, ali i dugi niz godina nakon toga ključno jest Engelsov stav o izvoru nejednakosti između muškaraca i žena. Nejednakost se, smatra Engels, ne generira temeljem Božje providnosti ili prirode (ibid.: 7), a promjenjivu prirodu društvenog statusa temeljenog na privatnom vlasništvu objašnjava instrumentarijem teorije materijalizma.

"Brak" feminizma i marksizma nije lako prihvaćen. Heidi Hartmann ga čak smatra neprihvatljivim jer se pažnja sa ženskog pitanja skreće na problematiku borbe protiv kapitala (1984: 172). Radikalno, iako ne u potpunosti krivo u tadašnjem akademskom kontekstu rasprave, autorica će reći da feminizam tumači opresiju u odnosu na muškarce kroz patrijarhalna uređenja, dok je marksizam rodno slijep te promatra žene kao dio radničke klase i njihovu opresiju sagledava isključivo u odnosu na ekonomske sustave. Takvim pristupom u kojemu su žene izjednačene s radničkom klasom (a vidjet ćemo da iskustveno nisu jednakopravni članovi te grupe), ženska se pozicija u odnosu na mušku podvodi pod odnos radnika nasuprot kapitala. Jasno je, posebno zahvaljujući intersekcionalizmu, a koji je glasno prihvaćen koju godinu kasnije, ne samo da nije moguće sagledavanje žena kao jednakopravnih sudionika radničke klase nego i da homogena struktura pod nazivom radnička klasa zapravo i ne postoji, kao što ne postoje ni homogene strukture unutar vladajućih klasa. Kako bismo obrazložili tu tvrdnju poslužit ćemo se primjerom koji u svojoj kritici Engelsa navodi Karen Sacks: "Svaka kategorija ženske vladajuće klase dijeli neke privilegirane aspekte s muškom vladajućom klasom, a koje ih razlikuju od seljakinja: sloboda od produktivnog rada za žene, seksualna sloboda za sestre i kćeri, politička i ekonomska moć za kraljicu majku i sestru. Ali nijedna od tih žena nema sve privilegije muškaraca 
iste klase. Potonje reflektira kontradiktornu poziciju žena vladajuće klase: one jesu privilegirana klasa, ali subordiniranog spola" (Sacks 1975: 227). Unatoč navedenoj kritici, Hartman smatra da snaga marksizma leži u njegovoj povijesnoj i materijalističkoj metodi, dok feminizmu pripisuje prednost u razvijenom iskustvu i metodi prepoznavanja patrijarhata kao društvene i povijesne strukture. Zajedničkim radom, ta bi se "progresivna unija" ogledala u boljem razumijevanju razvoja zapadnog kapitalizma i teške pozicije žena u takvom sustavu (Hartman 1984: 186). O nužnosti kombiniranog pristupa pisat će i Linda McDowell, koja će u pregledu klasnih analiza najprije ustvrditi (kao gotovo svi autori prije nje, a od kojih smo neke i naveli u ovom radu) da se u prijašnjim vremenima (dakle, u začecima industrijalizacije, ali i sve do poslijeratnog perioda), svijet rada (javna sfera) izjednačavao sa svijetom muškaraca, a maskulinitet je bio gotovo sinonim za rad. Vrijednost muškarca i njegov identitet bili su isključivo povezani s domenom rada. ${ }^{48}$ Klasna se razlika svodila na distinkciju između srednje radničke klase koju su zauzimali upravitelji pogona i niže radničke klase koju su zauzimali radnici u manufakturnoj proizvodnji. Također, status osobe koja privređuje (dakle, općeprihvaćeno muškarca) automatizmom se preslikavao na cijelu obitelj određujući tako njezinu klasnu lokaciju. U pregledu problematike radničke klase u kontekstu suvremenih istraživanja kraja 20. i početka 21. stoljeća, McDowell ističe dva ključna pitanja: prvo je pitanje o granicama koje obuhvaćaju pojam klase, a drugo o načinu na koji uključiti žene u klasnu strukturu. Prvo pitanje je prije svega uvjetovano razvojem uslužne djelatnosti i educiranih, visokoprofesionaliziranih $\mathrm{i}$ individualiziranih radnika koji stvaraju sebi svojstvene radne identitete. Za nas je relevantnije drugo pitanje - iako ne isključuje i prvo s obzirom na to da žene također participiraju u pomicanju granica određivanja klase temeljem individualiziranog profesionalizma - a tiče se argumenta koji je dominirao analizom klasa 1980-ih i 1990-ih godina i koji je težio razjašnjenju analitičke jedinice klase. Naime, da li analizirati domaćinstvo unutar kojega je muškarac onaj koji privređuje te se klasna određenost generirana njegovim radom reflektira na cijelu obitelj kao klasnu jedinicu ili je svrsishodnije istraživati individualne pozicije. Iako javno prihvaćenog konsenzusa nije bilo, istraživačka se praksa usmjerila k potonjem (McDowell 2006: 832-833).

\footnotetext{
48 Tezu o izjednačavanju muškog identiteta s njegovom profesijom, a time i zadobivenim društvenim statusom dokazat ćemo u ovom radu temeljem primarnih povijesnih izvora.
} 
Zaključimo da su informacije o ženskom radu, konkretno s kraja 19. stoljeća (a vjerojatno i ranije) pa sve do početka Drugog svjetskog rata, u različitim društvenopolitičkim uvjetima i geografskim lokacijama rijetko dokumentirane te da do nas dolaze u formi suvremenih (od 1970-ih godina naovamo) analiza posredstvom usmene predaje, često akumulirane u obiteljskim sjećanjima. Iz navedenih je primjera razvidno da se čak i onda kada su radile njihov rad nije tretirao radom u punom smislu riječi (javna, plaćena pozicija koja generira profesionalni identitet), a u nekim su slučajevima pod pritiskom društvenih očekivanja koja su im nametala ulogu kućanice i majke bivale i obeshrabrene $^{49}$ ostaviti dom i započeti plaćeni rad, koji je vrlo često podrazumijevao promjenu mjesta stanovanja. Pritom se nitko nije protivio dodatnom izvoru financija. Čitajući istraživanja Linde McDowell u kojima je inspiraciju i podatke za analizu temeljila na iskustvima vlastite obitelji, a koja su zahvaljujući sjećanjima njezine majke i bake sezala do kraja 19. stoljeća i obuhvaćala ženske radničke identitete britanske tekstilne industrije, posebno me zaintrigirala fokusiranost McDowell, ali i drugih znanstvenica, na suvremene promjene unutar radničke klase koje pripisuju aktivnijem prisustvu žena tek od 1980-ih naovamo. Naredni redci ove disertacije, ali i svjedočanstva koja, primjerice, McDowell navodi u radu "Border Crossings: Reflections on Women's Lives in Twentieth-Century" (2014), pokazuju da su žensku problematiku koja se pripisuje zapadnokapitalističkom suvremenom društvu kasnog 20. stoljeća radnice itekako osjećale i proživljavale barem sto godina prije, uključujući prekarijat, disbalans prouzrokovan obavezama u domaćinstvu i brizi o bližnjima u kombinaciji sa zahtjevima profesionalnog života, nižu plaću za jednak rad, da nabrojimo samo neke.

Prihvaćajući samo djelomično Engelsove pretpostavke o izvoru nejednakosti u imovini, pa time upućene na istraživanja u domeni klasnih sustava, feministkinje su aktivnim promišljanjem raznolikosti iskustava koja su im bila dostupna vrlo brzo

\footnotetext{
${ }^{49}$ McDowell navodi: “1904., (...) zaposlenje se smatralo distrakcijom od domaćinstva: stajalište koje će stoljeće kasnije biti preokrenuto naglavačke. Istraživanje obiteljskog života početkom 20. stoljeća u industrijskoj zoni koja je obuhvaćala šest gradova i čija je djelatnost počivala na proizvodnji keramike (engl. the Potteries) pruža nam odličan primjer za takvu tvrdnju: djevojčice su se zapošljavale s 13 godina kako bi se uzdržavale, ali i kako bi osjetile uzbuđenje tvorničkog života radeći s brojnim različitim osobama. U takvim su slučajevima djevojke odrastale potpuno nespremne za kućanske poslove. 'Sve dok ih se još kao djevojčice ne bude učilo uživanju u kućanskim poslovima i dok ne bude primjerenih slobodnih aktivnosti i zabave dostupnih svakoj ženi koji bi se suprotstavili bijedi i sumornosti tih tvorničkih gradova, uzaludno je očekivati da će se djevojke odreći tvorničkog života' (Great Britain Cmnd 2175, 1904, para. 259)" (McDowell 2014: 162).
} 
osvijestile poziciju višestruke subordinacije žena koja kreće od zauzimanja subordinirane rodne pozicije, odnosno bivanja žene u muško-dominantnom sustavu, a zatim se razotkriva u svojoj mnogostrukosti (rasa, nacionalnost, fizičke predispozicije i dr.) i analizira ovisno o kontekstu istraživanja.

\section{DRUŠTVENO-POVIJESNO SITUIRANJE PREDMETA}

\section{1. Crtice iz ekonomske povijesti Rovinja}

\section{3. godine Molin (rovinjski Podest) piše 'Rovinj je najnapučeniji i najpoduzetniji grad u Provinciji, ${ }^{50}$}

O ekonomskoj povijesti Rovinja najopširnije informacije donosi Bernardo Benussi 1888. godine. U predgovoru se zahvaljuje kanoniku Tomasu Caenazzu, koji mu je na raspolaganje stavio svoje rukopise, Carlu De Franceschi, koji mu je ukazao na kronike Biancinija, ${ }^{51}$ a zatim Pokrajinskom odboru Istre, rovinjskom Sudu, rovinjskom Gradskom vijeću, Državnom arhivu u Veneciji te Gradskom muzeju u Veneciji, koji su mu, kako navodi, omogućili uvid u relevantnu dokumentaciju (2004 [1888]: predgovor). Prema tome, jasni su izvori iz kojih Benussi gradi povijest Rovinja i predstavlja je devetnaestostoljetnoj publici. O ekonomskoj povijesti Rovinja pisat će, uz ostale kraće i specifičnije doprinose, ${ }^{52}$ povjesničar Marino Budicin više od stotinu godina kasnije. Iz tih sekundarnih povijesnih izvora saznajemo da je Rovinj za vrijeme

\footnotetext{
50 "U ranom srednjem vijeku Rovinj je bio naselje s utvrdom na vrhu brežuljka te s crkvom sv. Jurja, u kojoj se čuvalo tijelo sv. Eufemije (prema legendi, čudovito doplutalo u mramornome sarkofagu). Poslije napadaja Neretljana, Hrvata i Saracena u IX-X. st. grad je opasan zidinama, te je njegova površina znatno porasla, a crkva je sred. X. st. proširena u trobrodno zdanje. U to vrijeme Venecija je, nudeći Rovinju zaštitu, ishodila od grada zakletvu vjernosti 1150., te potpuno podčinjene 1283. Sedam stoljeća mletačke vlasti (do 1797.) bilo je za Rovinj doba stalnoga rasta: demografskoga, gospodarskoga i urbanoga, te je u XVII.-XVIII. st. postao jedan od najnapučenijih gradova sjevernog Jadrana i najvažnije ribarsko i pomorsko središte mletačke Istre" (Budicin. M, istrapedia.hr/rovinj-istra/, pristup 25. 11. 2019.).

${ }^{51}$ Biancini, doktor medicine namješten u Rovinj, suvremenik je događaja o kojima izvještava (1760.1806.) (Benussi 2004 [1888]: 99), za razliku od Angiolinijevih kronika nastalih između 1858. i 1862. godine, a koje podacima obuhvaćaju period od kasnog 17. do sredine 19. stoljeća (Radossi G i Pauletich A. Repertorio alfabetico delle cronache di Rovigno di Antonio Angelini, Atti del Centro di ricerche storiche di Rovigno, 1976.-1977.).

${ }^{52}$ Budicin M. i Miculian, M. 1984. Le manifatture rovignesi nella seconda metà del secolo XIX. Zbornik radova sa znanstvenog skupa "Susreti na dragom kamenu", 12; Sella, A. i Sella, M. 1940. "L'industria del trepang". Thalassia, 4.
} 
Mletačke Republike (1283.-1797.) bio jedan od najrazvijenijih gradova Istre, ali, podaci će pokazati, i vrlo važno uporište mletačke ekonomije. Kroničari rovinjske povijesti naglašavaju poduzetni duh Rovinjaca, marljivost i inovativnost, posebno u smislu korištenja prirodnih resursa koji ih okružuju. Biskup Tommasini će u svojim opisima istaknuti kako je rovinjsko zemljište brdovito i kamenito, ali su i takvu zemlju vrijedni Rovinjci obradili zasadivši vinovu lozu i masline, zahvaljujući čemu su proizvodili bijelo i crno vino te ulje u velikim količinama. Istu karakternu crtu, dakle marljivost i poduzetništvo Rovinjci će pokazati s početkom razvoja industrije (ibid.).

Uz ribarstvo i poljoprivredu, Rovinjci se vrlo brzo okreću obradi kamena, pomorstvu, brodogradnji i trgovini. Svaka od tih djelatnosti ima zasebnu cehovsku organizaciju, a broj od njih ukupno dvadeset i dvije vjerno govori u prilog poduzetničkom rovinjskom duhu. Interese mletačke ekonomije štitio je Rovinjski Statut iz 1531. godine, kojim ne samo da su definirane cijene već i proizvodne kvote te specifična pravila, primjerice zabrana kupovine stranog vina, status javnih pekara koje se daju u najam privatnicima, ali koji moraju od fontika (gradske žitnice) kupovati žito, obaveza prodaje ribe na javnoj gradskoj tržnici uz dadžbinu od 1/8 cijene ribe (kasnije zbog velikog siromaštva 1/20). Postojala je također obaveza tiještenja ulja u općinskim mlinovima $^{53}$ (Benussi 2004 [1888]: 113-115). Rovinj i drugi istarski gradovi Veneciju nisu zanimali samo zbog luka, brodova, pomoraca i solana nego je i pažljivim planiranjem Serenissima na tom području razvijala vlastitu žitnicu. Tome u prilog govori podatak da je već 1330. grad dobio poticaj od 1647 lira kako bi kupili govedo kojim će orati i održavati zemlju. Također saznajemo da se 1595 . godine 150 obitelji bavi poljoprivredom (ibid.: 131). Zanimljivo je da će se poljoprivredom uglavnom baviti pridošlice, a da će Rovinjci dalje razvijati ribarstvo, koje značajniji razvoj i profit donosi tek krajem 17. stoljeća zahvaljujući novom otkriću u tehnici lovljenja srdela (ibid.: 139). Toj inovaciji dugujemo početke industrije soljenja ribe. Naime, nakon tog otkrića broj bracera $^{54}$ se sa 60 penje na 140 , a ulovljena se riba soli u kućanstvima, pri

\footnotetext{
${ }^{53}$ Do sredine 17. stoljeća mlinovi se nalaze unutar gradskih zidina, iako ne znamo sa sigurnošću gdje. Tada započinje ekspanzija i na kopnu, pa 1784. godine Rovinj broji 7 aktivnih mlinova. Zanimljiva je konstatacija da predispoziciju za razvoj industrije 1763. čini zatrpavanje kanala i spajanje gradske jezgre s kopnom. Upravo se tu otvaraju najprije brodogradilišta i mlinovi, a kasnije drugi industrijski pogoni (Budicin 1997: 426).

${ }^{54}$ Tip istočnojadranskog jedrenjaka s jednim jarbolom s latinskim jedrom.
} 
čemu su muškarci lovili ribu, a žene i djeca bili zaduženi za postupak soljenja (Mogorović Crljenko i Doblanović 2015: 240). Usoljena se riba potom slala u Veneciju i dalje u Lombardiju. O važnosti te "industrije" i opsegu tržišta govori nam podatak o količini soli koju je Venecija osiguravala Rovinju za potrebe soljenja ribe i maslina. Godine 1753. za tu je priliku potrošeno 360 bušela $^{55}$ za razliku od 50 bušela 1692. ili 180 bušela 1712. godine. Dodajmo tome da je u prvoj polovini 18. stoljeća trgovinom soljene ribe Rovinj godišnje zarađivao 50000 zlatnih dukata (tada je 1 dukat odgovarao 3,54 g čistog zlata) (Budicin 1997: 419). Međutim, osim prosperiteta, to je otkriće Rovinjcima donijelo i stoljetne borbe oko prevlasti nad Zaljevom sa stanovnicima Chioggie (ibid.: 140).

Najranija rovinjska industrijska djelatnost (ili bolje reći obrtnička) veže se uz eksploataciju kamena i to već od 14. stoljeća. Rovinjski su kamenoresci kamenom uglavnom trgovali i to prvenstveno s Venecijom i Anconom, ali i drugim gradovima Romagne (ibid.: 143). Tek se manji dio kamena koristio lokalno. Uz kamenoresce, od 17. stoljeća napreduju i brodograditelji. Rovinj je za vrijeme najveće ekspanzije pomorstva i ribarstva, dakle kroz 17. i 18. stoljeće brojao sedam brodogradilišta. Slijedom toga, povijesni izvori navode da je 1735. godine bilo toliko brodograditelja da su osnovali vlastitu bratovštinu, da 1780. u Rovinju nalazimo deset velikih pila, a krajem 18. stoljeća u luci brojimo više od 200 brodova. Ništa manje značajan nije broj kapitana (120) koje je Rovinj “dao" za Veneciju, među kojima 12 kapitana ratnih brodova (ibid.: 144-145). Zaključno, Rovinj je u jeku razvoja, 1780. godine brojao 200 trgovaca, 400 obrtnika, 555 pomoraca i vlasnika brodova, 1165 ribara, 1030 poljoprivrednika, 120 sluga, 50 osoba bez ikakvog zanata i 150 prosjaka (ibid.: 145). Ako znamo da je u Rovinju 1788. živjelo 9816 osoba (ibid.: 8), lako ćemo zaključiti kako su se u navedena zanimanja, odnosno "proizvodnu snagu" ubrajali samo muškarci. Također, dotad je 70\% radne snage spadalo u primarni sektor, a u obrtništvo i trgovinu svega $16 \%$. U tom razdoblju ne možemo govoriti o industriji kakva se $u$ to vrijeme uvelike razvija, primjerice, u Engleskoj. Rovinj je svoje značajnije industrijske početke doživio u sklopu Austro-Ugarske Monarhije, tek sto godina kasnije.

\footnotetext{
${ }^{55}$ Bušel (engl. bushel) (znak bu), angloamerička jedinica obujma suhih tvari, vrijednosti britanski bu $=8$ galona $=36,368 \quad 72 \mathrm{~L}$, američki bu $=2150,42 \quad \mathrm{in}^{3}=35,239 \quad 070 \quad 160 \quad 88 \quad \mathrm{~L}$ (gallon) (http://www.enciklopedija.hr/natuknica.aspx?id=10348, pristup 25. 11. 2019.).
} 
Koji je dakle položaj i uloga žena u takvoj, primarno-sektorskoj ekonomiji? O ekonomskom položaju rovinjskih žena u kasnom srednjem vijeku i novom vijeku Benussi (1888) i Budicin (1997) ne donose gotovo nikakve informacije. Pisanje u muškom rodu za sva navedena zanimanja (pa i ono sluge) upućuje da se odnose upravo na muškarce. Također, brojčano stanje upućuje na 1/3 stanovništva, što, kad se oduzmu starci i djeca, odgovara okvirnom broju radno sposobnih muškaraca. Žene se u ekonomskom kontekstu spominje usput, ne kao aktivne sudionice, već isključivo kao podršku suprugu i djeci, kod pitanja nasljedstva i sastava miraza. ${ }^{56}$ Tek kada objašnjava razloge zbog kojih je gradonačelnik Campitelli zagovarao otvaranje tvornice duhana, Benussi navodi da su dotad žene "svoj kruh zarađivale teškim radom u polju i ručnim mljevenjem žita” (Benussi 2004 [1888]: 235).

Nakon pada Mletačke Republike 1797. godine Rovinjem nakratko vlada Austrija (Habsburgovci), da bi Napoleon 1805. ponovno zauzeo bivšu mletačku Istru. Austrijska se vlast vraća 1814. godine te kroz sustav apsolutne monarhije, a kasnije (1867.) dvojne monarhije (Austro-Ugarska) razvija rovinjsku industriju, školstvo, prostorno planiranje, cestovnu infrastrukturu i zdravstvo. Austrija, dakako, nije razvijala industriju samo u Istri već i u ostalim zemljama koje je tada, posebno po nagodbi s Mađarima, osvojila. Važno je pritom istaknuti kako je Austrija "samo" slijedila svjetske ekonomske i tehnološke tokove koji su tada već uvelike zašli u drugo industrijsko doba (1860.1918.). ${ }^{57}$ Tehnološka revolucija se na Rovinj, kao i na ostale urbane zajednice, reflektirala porastom broja stanovnika i prelaskom iz primarnog u sekundarni sektor. Brojni autori tumače kako je za "rad na strojevima potreban manje stručan rad pa je industrijalizacija uvelike obilježena padom korištenja kvalificiranog rada (de-skilling) i rastom potražnje za nekvalificiranom radnom snagom, uključivo onog žena i djece"

\footnotetext{
${ }^{56}$ Benussi donosi cjelovite popise miraza iz 1618. i 1736. godine, a koje uobičajeno kod bogatijih obitelji sastavljaju javni bilježnici. Iz tih popisa možemo detaljno saznati što su bogatije građanke odijevale i na koji su način uređivale dio kućanstva (2004 [1888]: 356-359).

57 "Prva je industrijska revolucija započela oko 1750., a završila je oko 1830. Nakon te godine više nema značajnih, široko primjenjivih otkrića pa se broj patenata smanjuje. Takvo stanje 'tehnološkog' mirovanja traje do oko 1860., kada započinje Druga industrijska revolucija. Konac druge tehnološke revolucije još uvijek je donekle sporan jer ga neki autori vide u 1918. godini (dok ga rijetki među njima čak smještaju u 1950-te)" (Bićanić 2017). Eric Hobsbawm začetke industrijalizacije također smješta u 1750-e, da bi 1780. započeo ekonomski i demografski rast koji traje do 1840 . godine i naziva se industrijskom revolucijom (1999: 12-56).
} 
(Bićanić 2017). Takvom generalizacijom žene su ponovno stigmatizirane kao nekvalificirane, što je omogućilo od začetaka industrijalizacije nejednaku plaću za muškarce i žene, čak i na istim pozicijama. Voljela bih ponuditi alternativno viđenje ženskog i dječjeg rada, a koje se temelji na bezdušnoj kapitalističkoj “funkcionalnosti” i profitabilnosti. Ako znamo da počeci industrijalizacije sežu u 1750. godinu u Engleskoj i da su već tada, dakle kada nije bilo mehanizacije u smislu pokretnih traka, djeca i žene činili znatan dio radne snage ${ }^{58}$ (Hobsbawm 1999: 37; Kirby 2003: 39), zapitat ćemo se kako je moguće da je isključivo ideja o padu potrebe za kvalificiranim radom povezana s povećanjem potrebe za ženskim radom. Nije li moguće da su zbog svojih fizičkih predispozicija (manja, lakša) djeca bila pogodnija za ulazak u rudnike, da su zbog višestoljetne drugorazredne društvene pozicije siromašna djeca i žene prihvaćali niže plaće što je investitorima svakako odgovaralo, te da su u određenim poslovima žene bile vještije, a time i kvalificiranije za poslove koje je diktiralo tadašnje tržište? Kako ne bismo upali u zamku generalizacije, fokusirat ćemo se na primjer duhanske i riblje industrije u Rovinju.

\section{2. Stereotipi o stanovništvu}

Da su žene imale relativno povoljan položaj u mletačkoj Istri i prije nagle industrijalizacije pokazuju nam povijesni podaci o politikama nasljeđivanja, povijesni spisi (najčešće sudski procesi) koji ukazuju na poslovno aktivne žene, djelomična zaštita žena kroz gradske statute, kao i pisanja kroničara o njihovoj svakodnevici. Iako su ta pisanja visoko stereotipizirana, ona nam otvaraju platformu za dekonstrukciju i ponovno iščitavanje ženske povijesne uloge u rovinjskoj zajednici. Mišljenja sam pritom, unatoč brojnim dokazima o poslovnoj aktivnosti žena u predindustrijskoj Europi, da su žene uključene u javne poslovne odnose iznimka, a da bi intersekcijska analiza povijesne i arhivske građe ukazala na drugorazrednu poziciju žena naspram muškaraca, siromašnih žena naspram bogatih, domaćih naspram strankinja.

\footnotetext{
${ }^{58} \mathrm{Za}$ više informacija o dječjem radu u doba industrijalizacije vidi Kirby, P. 2003. Child Labour in Britain 1750-1879.
} 
Nekoliko je ključnih izvora, mimo statističkih podataka dobivenih iz matičnih knjiga, koji nam donose podatke o novovjekovnim Rovinjkama: pisanja novigradskog biskupa Tommasinija, ${ }^{59}$ uspomene javnog bilježnika dr. Costantinija, te kronike Biancinija i Angiolinija. Izvori su objedinjeni u velikoj mjeri u Benussijevoj Storia documentata di Rovigno. Za potrebe ovog rada fokusirat ćemo se na ono što Benussi odabire iz povijesnih izvora kako bi oslikao Rovinjku. Benussi se gdjegdje kritički odnosi prema stavovima svećenika Tommasinija, no samo tada kada brani jednostavnost Rovinjaca; na ostalim mjestima on uglavnom prenosi zapise, što upućuje na nepromjenjive stavove i moguće strategije regeneracije i održavanja stereotipa. Stereotipe ćemo u ovom kratkom podpoglavlju tretirati "ne kao kulturne otpatke, već kulturne proizvode koji nastaju pod utjecajem političkih i kulturnih procesa, ali i sami utječu na oblikovanje i usmjeravanje društvene stvarnosti” (Ograjšek Gorenjak 2014: $5)$.

$\mathrm{Na}$ početku poglavlja o rovinjskom stanovništvu Benussi prenosi Tommasinijevu rečenicu "Stanovnici Rovinja su nepristojni i loše odjeveni. Nema plemićkih kuća, već su svi siromasi, ali lijepog izgleda, a jednako su lijepe i žene" (Benussi 2004 [1888]: 173), kojom Tommasini želi istaknuti grubost i jednostavnost Rovinjaca, za što su, prema njegovu mišljenju, ponajviše krivi došljaci iz sjeverne Italije, Dalmacije, Albanije, pa čak i Grčke -poljoprivrednici, ribari, pomorci, obrtnici, dakle neobrazovana "radnička klasa". Domoroci nisu ništa bolji. I oni pripadaju klasi poljoprivrednika i ribara, ali se samoidentificiraju gostoljubivima, što se ogleda $u$ natpisu koji su sami postavili na ulaz u grad - Rovinj je "Reposso dei deserti" (“Skrovište za napuštene”). U nastavku teksta Benussi kritizira Tommasinijev stav o siromaštvu jer u arhivima nalazi bilježničke zapise o izdašnim mirazima i to već od 1543. godine, a navodi i da su "obične" žene u miraz donosile svilene marame. Razvojem ekonomije, sredinom 17. stoljeća, Rovinj doživljava prvi ekonomski procvat. Benussi smatra da su tom procvatu pridonijele i žene jer svojom virilnom energijom nisu samo održavale kućanstvo nego su vrlo često bile i mozak svih muževljevih poslova. Činjenica da Rovinj postaje snažna trgovačka karika mletačke ekonomije tom malom ribarskom gradiću ne donosi samo luksuzna materijalna dobra kojima dotad nisu

${ }^{59}$ De Commentari storici geografici della Provincia dell'Istria, libri otto (1641). 
imali pristup već i interkulturne susrete. Costantini već 1708. godine uočava posljedice tog bogaćenja i snažnijeg utjecaja venecijanske uprave na rovinjsku svakodnevicu. Stanovništvo mijenja način odijevanja, bogatiji građani počinju koristiti perike, a žene se odijevaju u busti alla veneziana. I seljačko stanovništvo poprima nešto od tog raskošnog venecijanskog stila; neugledne haljine postaju nešto duže, a manjim izmjenama krojeva i decentnije. Za pokrivanje glave umjesto pescanizze počinje se nositi zanda alla veneziana, a oko vrata zlatni lanac s dijamantnim križem. Međutim, s raskošnim odijevanjem dolaze korupcija i pad morala. Benussi će po tom pitanju u centar pažnje staviti žene: one više ne nalaze ukras u skromnosti, svađe oko žena postaju sve češće, a zbog grube i nasilne naravi muškaraca (koji su, prema opisima kroničara, dotad bili jednostavni, ali dobri i gostoljubivi) završavaju krvavim obračunima. Sve su češći i razvodi jer je lagodan i neozbiljan život snažno poljuljao svetost obitelji, zbog čega je Vijeće desetorice optužilo isključivo žene. Dekretom iz 1782. godine traži se od Biskupije pomoć u sprječavanju razvoda jer su žene do te mjere raspuštene, slobodne i izvan bračne kontrole da loše utječu ne samo na pristojne sugrađane već i na obiteljsku ekonomiju te pružaju loš primjer djeci. Drugim dekretom iz 1783. godine Vijeće desetorice traži da se nedostojno ponašanje žena u crkvi ispravi tako što će na misu obavezno dolaziti pristojno odjevene i pokrivene, u skladu sa svojim društvenim statusom (Benussi 2004 [1888]: 173-180).

$\mathrm{Na}$ tristo stranica Benussijeve rovinjske povijesti žene su dobile svoje "zasluženo" mjesto. One su prije svega lijepe, u ekonomiji ih krasi virilna energija posebno kod održavanja domaćinstva i vođenja muževljevih poslova, dakako iz sjene. Kada u društvu opadne moral, one su prve i jedine koje za to snose odgovornost. $\mathrm{O}$ stereotipima koji krase Rovinjke plastično govore dva recentna događaja. Jedna od mojih kazivačica je u svakom razgovoru isticala narav Rovinjki kao da je samorazumljivo da ona podrazumijeva slobodne manire, a da se pod slobodnim manirama podrazumijeva seksualna sloboda. Drugi primjer je osobne prirode i tiče se mojeg prvog zaposlenja. Naime, po dolasku u Pazin jedna me je djelatnica označila kao “opasnu Rovinjku”. Povijesni podaci o ženama kao slobodnima i raspuštenima, ali istovremeno virilno energičnima, zasigurno su utjecali na buduće stereotipe o 
Rovinjkama, koje su možda upravo zbog njih i mogle postati snažnim, emancipiranim hraniteljicama Rovinja, kako ih do danas pamti društveno sjećanje.

\section{3. Poslovna sposobnost žena do industrijalizacije}

Za razliku od Benussija (1888) i Budicina (1997), povjesničarka Marija Mogorović Crljenko svoj će rad $(2006,2012)$ posvetiti upravo položaju i ulozi istarskih žena kroz povijest. Obradila je pritom ne samo ženski položaj u društvu nego i unutar četiri zida, otvarajući prostor za rasvjetljavanje niza tema koje smo dosad rijetko susretali u domaćim povjesničarskim radovima, a koje se tiču izbora bračnog partnera, intimnih odnosa supružnika, uloge majke, odnosa s roditeljima te braćom i sestrama, preljuba, prostitucije, zlostavljanja i dr. Za potrebe ovog rada navest ću samo primjere koji upućuju na poslovnu sposobnost žene. Iako autorica tek ponegdje uključuje rovinjske primjere, činjenica je da se status žena ne razlikuje puno od jednog do drugog grada, posebno ako govorimo o mletačkoj Istri i određenom povijesnom periodu.

Mogorović Crljenko u radu o istarskim ženama u 15. i 16. stoljeću (2006) piše kako su žene koje nisu imale plemićki stalež uživale kakvu-takvu poslovnu sposobnost $\mathrm{i}$ mogućnost djelovanja, čak iako je to često bilo ograničeno dobrom voljom njihova supruga ili oca. Nasuprot tomu, plemkinje su bile strogo čuvane te je njihova poduzetnička aktivnost više iznimka nego pravilo. Mogorović Crljenko, kao i brojne druge povjesničarke i antropologinje, ističe činjenicu da je ženska poslovna sposobnost zapravo ograničena njezinom lokacijom. Žene, dakle, prema njezinu mišljenju, nisu samostalno izlazile iz kuće jer je takav čin smatran riskantnim (Mogorović Crljenko 2006: 107). S autoričinom se tezom o riskantnosti izlaska kao razlogu ženske ograničenosti na kuću i domaćinstvo međutim ne bih složila, sklonija sam vjerovati da je taj rizik samo posljedica svjetonazora o ženskoj drugosti, pa samim time i posljedica njezine "dugotrajne ekonomske izoliranosti”. Istarski statuti bilježe krčmarice, pekarice, prodavačice brašna, kruha, mlijeka, maslaca, ulja, povrća i vina. Mogorović Crljenko prenosi i istraživanje Darje Mihelič provedeno u Piranu, gdje su zabilježena zanimanja prodavačice žita te žene koje se bave ribarenjem. Dodatno, Mihelič u svom istraživanju ženskih zanimanja navodi i ona koja se smatraju dostojnima, odnosno nedostojnima. 
Dostojna zanimanja i društveno prihvatljivi obrti su oni poput pekarice i mlinarice te trgovina, dok je nedostojno i neprihvatljivo zanimanje sluge i svodnice (ibid.: 105). Do sličnih podataka dolazi i Marija Karbić, koja obrađuje poslovnu sposobnost žena u gradskim naseljima međurječja Save i Drave na temelju normativnih akta i dokumenata nastalih iz svakodnevne prakse. Osim što navodi cijeli niz ženskih poslova od 13. stoljeća naovamo, Karbić spominje za moju temu dva važna detalja: da je gradsko društvo, koje ona u svom radu obrađuje, određeno činjenicom da su žitelji analiziranih naselja bili ili trgovci ili obrtnici i da su žene prema statutarnim odredbama cehova mogle nastaviti voditi posao nakon suprugove smrti te su im u tim slučajevima članovi ceha morali doznačiti vješta kalfu koji će im, dok god su udovice, pomoći u vođenju zanata. Pritom Karbić zaključuje da su kalfe najčešće postajali novi muževi majstorica (Karbić 2004: 59-60). Ako su one zaista bile slobodne majstorice, zašto je bilo nužno postaviti vješta kalfu? Te, ako su stanovništvo činili isključivo trgovci i obrtnici, nije li prirodno da će posao naslijediti udovice s obzirom na to da nemaju kako drugačije preživjeti i da u protivnom ostaju na teret zajednici? Karbić navodi da se u odredbama gradečke gradske uprave govori o isključivo ženskim zanimanjima poput piljarice i dojilje, a navodi i da postoje brojni primjeri poslovno aktivnih žena koje nisu bile samo neudane ili udovice već su i žene u braku bile uključene u različite gospodarske aktivnosti (ibid.: 63). Kako to često biva s povijesnim izvorima, vrlo je nezahvalno govoriti o "mnogim izvorima", a koji nam zapravo donose nekoliko imena od tadašnjih nekoliko tisuća stanovnika koji su nastanjivali gradove i naselja o kojima je riječ. Ne možemo sa sigurnošću znati jesu li te žene zaista bile slobodne u poslovnom smislu ili su zbog egzistencijalnih potreba morale raditi, jer je, primjerice, muž bio bolestan ili je, što je vrlo vjerojatno, bio zauzet radom na polju pa ona je prodavala njihove proizvode. Uzgred rečeno, u rovinjskom statutu (Kandler 1853) kao "poslovne žene" spominju se samo piljarice, dakle žene koje su prodavale obiteljske proizvode. Osim toga, činjenica da su se obiteljskim poslovima bavili svi ukućani ne znači da je ženama priznavana poslovna sposobnost ni da im je takav rad donosio zaradu, vlasništvo ili određenu razinu neovisnosti.

Ako uzmemo u obzir etnološku literaturu s opisima rodno diferenciranih poslova, možemo zaključiti da su žene prije svega vodile kućanstvo, a zatim i pomagale 
uzdržavanju obitelji tako što su prodavale proizvode iz vlastitog polja ili su odlazile u mlin. Na rovinjskom je primjeru posebno važno razumjeti da su ribari i pomorci često bili odsutni pa je poslovna aktivnost žena i više nego očekivana, možemo reći čak i uobičajena. Dodatno, Mogorović Crljenko ističe da je za obiteljske poslove (poput mlinarstva, ugostiteljstva-krčmarstva ili pekarstva) u zapadnoj Europi bilo uobičajeno da u radu sudjeluje cijela obitelj (Mogorović Crljenko 2006: 105). Nadalje, udovice nisu imale zaštitu te su, da bi prehranile djecu i sebe, vrlo često bile primorane baviti se javnim poslovima, poput trgovine i raznim obrtima, ali i nastaviti obrt koji je do smrti vodio suprug. Dakle, osim iznimnih poduzetničkih primjera, žene su u pravilu ograničene na kućanstvo, a tek one siromašnije i/ili udovice pod teškim pritiskom egzistencije moraju raditi i izvan kuće. Zanimljiva su tri primjera poslovne sposobnosti žena koje u svom radu iz 2006. godine navodi Mogorović Crljenko. Prvi je primjer pekarice Paule Dente, članice bogatije novigradske obitelji čiji su članovi sudjelovali u radu gradskog vijeća. O Pauli Dente saznajemo iz sudskog procesa koji se protiv nje i meštra Vida Bona vodio jer jedan dan nisu pekli kruh. Činjenica da se spominje meštar podsjeća na slučaj kalfe koji u svom radu donosi Karbić, a koji nas navodi na zaključak (na koji i Mogorović Crljenko upućuje) da je Dente bila vlasnica pekare, a da je pekar zapravo bio Vid Bono. Paula Dente je temeljem nasljednog prava (brak na istarski način) i temeljem obiteljskih veza (imućna novigradska obitelj koja sudjeluje u radu gradskog vijeća) postala vlasnica pekare, time neposredno i poslovna žena, međutim ona nije bila pekarica, nije radila ili nije bila poslovno sposobna u smislu da joj je njezin rad donosio ravnopravnost, slobodu i društveni status. Iako su, prema Mogorović Crljenko, udovice uživale veće slobode od udanih žena (ibid.: 103), pristupimo li ovoj konstataciji i predočenim činjenicama iz pozicije intersekcijske analize, moći ćemo ponuditi i nešto razrađeniji zaključak, a to je da su samo bogate udovice imale slobodniji položaj u odnosu na udane žene. U prilog tome govori i istraživanje Slavena Bertoše koje u Nepoznatom svijetu istarske žene navodi Mogorović Crljenko. Prema tom istraživanju, razvidno je da su se žene više puta udavale ${ }^{60}$ što upućuje na to "da je

\footnotetext{
60 "Slaven Bertoša, analizirajući stanovništvo Pule na temelju matičnih knjiga za razdoblje 1613. do 1815. godine, donosi podatke koji pokazuju da je veliki broj žena ulazio u drugi brak. Naime, od ukupno 1772 braka koji su sklopile žene u tom razdoblju, $401(22,6 \%)$ se odnosilo na drugi, 37 (2\%) na treći, 5 $(0,28 \%)$ na četvrti te $2(0,11 \%)$ na peti brak" (Mogorović Crljenko 2006: 33$)$.
} 
udovicama bilo puno teže opstati i pobrinuti se za egzistenciju te je vrlo vjerojatno da su se mnoge mlade udovice preudavale" (ibid.: 33).

Drugi primjer govori o prisustvu mlinarica. Autorica navodi podatak o Marinu Bogoviću, koji, nakon što je od svojih dviju sestara naslijedio nekoliko mlinova, pokazuje bratsku ljubav i prema trećoj sestri Ivani Bogović te joj u nasljedstvo ostavlja dijelove mlina. Zašto je samo toj jednoj sestri ostavio mlin, nije poznato. S obzirom na vlasništvo nekoliko mlinova, moguće je, ponovno, da se radi o imućnijoj obitelji, da su roditelji preminuli, da se Ivana nije udavala i da je kao nasljednik svega brat morao skrbiti o sestri. Ovo nipošto ne znači da je ona radila u mlinu. Slično kao u slučaju Paule Dente, riječ je o nasljednom pravu, a koje je jednako naklonjeno muškoj i ženskoj djeci kao i udovici (ibid.: 103-104).

Posljednji primjer iz povijesnih izvora govori o kćerki mlinara iz Brtonigle za koju je zabilježeno je da je bila prisutna među ženama koje su mljele brašno. Razlog bilježenja takve pojave nije poznat, no ono što jest Mogorović Crljenko navodi prema izvoru iz državnog arhiva u Pazinu. Kao što će Mogorović Crljenko zaključiti, a što smo ranije naveli, u gradskim i seljačkim obiteljima zapadne Europe u obiteljskom su poslu sudjelovali svi članovi obitelji, stoga činjenica da se kći zatekla u mlinu ne znači da su žene samostalno radile kao mlinarice. U ovom je slučaju vjerojatnije kako je to bio dio njezinih svakodnevnih obaveza uz kućanske poslove te da za taj rad nije primala nikakvu naknadu (ibid.: 105). Ostale žene koje su dolazile mljeti brašno činile su to u sklopu svojih kućanskih obaveza, a muškarci su najčešće radili u polju. No oni su se u matičnim knjigama vodili kao poljoprivrednici, a žene su bile i ostale (sve do početka 20. stoljeća) nevidljive.

Međutim, postoji niša gdje su žene zaista bile aktivne izvan kućanstva. Mogorović Crljenko navodi primjer barbanskog hospitala, obnovljenog nakon 1576. godine, u kojemu je bila postavljena nadstojnica koja je trebala stanovati u samom hospitalu, njegovati bolesnike i skrbiti o njihovoj odjeći (ibid.: 106). Također, žene se spominju ponajviše u području opstetricije. Zanimanje babice bilo je jedno od redovito zastupljenih ženskih zanimanja (ibid.: 105). Iako se druga ženska zanimanja u 
povijesnim izvorima, poput matičnih knjiga, ne spominju, babice su u tim izvorima i više nego prisutne, što ukazuje na to da izostanak ženskih zanimanja iz matičnih knjiga nije pitanje njihova stvarnog javnog odsustva, već pokazatelj sekundarnog društvenog statusa žena i njihova sistemskog prešućivanja. Mogorović Crljenko daje i mogući razlog isključivog navođenja babica. Naime, babice su pomagale pri porođaju i u slučaju smrtne prijetnje, a imale su i ovlast krstiti dijete. Također, bile su jedini svjedoci u slučajevima čedomorstva, a u takvim su prilikama bile dužne intervenirati i počiniteljice prijaviti vlastima (ibid.). U tom je kontekstu vrijedno spomenuti jednu od rijetkih žena koju rovinjski povjesničar Benussi spominje: “1582. godine, posljednjeg dana u veljači, umire Donna Bortola, žena velike dobrote, prijateljica siromašnih, napola kirurginja, školovana doktorica koja je u ime Božje liječila sve siromašne" (Benussi 2004 [1888]: 189). Prisjetimo li se europskog Izvješća o segregaciji zanimanja s prvih stranica ovog rada, čini se da je ženski rad izvan domene industrije stoljećima snažno obilježen elementima brige o bližnjima (liječnice, babice, njegovateljice, sluge, dadilje) te da se društvena (rodna) uvjetovanost zanimanja mijenja sporo ili se pak uopće ne mijenja.

Zahvaljujući naporima povjesničara, poglavito povjesničarki, da iz šturih i fragmentarnih povijesnih podataka, statuta i sudskih sporova rekonstruiraju živote žena, danas možemo više znati o ženskom doprinosu ranoj novovjekovnoj ekonomiji, njihovu doprinosu obiteljskom poslu, naslijeđenim obrtima, o samostalnom radu u pekari ili hospiciju, ali i o razlozima njihove društvene nevidljivosti. Ti su nam podaci bitni kako bismo mogli razumjeti društvene, političke i ekonomske okolnosti koje prethode industrijskom razdoblju Rovinja u kojem dolazi do snažnog i brojnog proboja žena na tržište rada. Stoga ću u narednim poglavljima analizirati rovinjske matične knjige prije uspostave industrijalizacije i po njezinoj uspostavi. Pritom ću ih smjestiti u određeni društveno-povijesni kontekst koji ne samo da je omogućio uključivanje žena u javni rad (one su dio društvenog rada, vidjeli smo, odavno) već je, što je važnije, dopustio da se ta aktivnost zabilježi i javno valorizira. 


\section{4. Brak na istarski način kao mogući uzrok rane emancipacije}

Teza da je rovinjskim ženama omogućena svojevrsna emancipacija kroz industrijski rad zahvaljujući, između ostalog, i povijesno zabilježenom povoljnijem društvenom i ekonomskom položaju u odnosu na žene iz drugih sredina ${ }^{61}$ u kojima takve predispozicije nisu postojale, temelji se prije svega na instituciji braka na istarski način. U srednjem i ranom novom vijeku brakovi u Istri najčešće su se sklapali na istarski način (usp. Margetić 1970; Mogorović Crljenko i Doblanović 2015: 256-257). Iako su postojali brakovi koji su se sklapali na mletački i na slavenski način, Mogorović Crljenko i Doblanović su dokazale kako su došljaci vrlo često prihvaćali lokalni uzus (ibid.: 257) što je vrlo simptomatično s obzirom na nezanemariv broj došljaka. Da je tadašnja Istra bila sustavno naseljavana stanovništvom iz najrazličitijih krajeva, od sjeverne Italije pa sve do Grčke, te da je novo stanovništvo zasigurno snažno utjecalo ne samo na demografske promjene već i na lokalne običaje, najbolje govori podatak da je koncem 16. stoljeća od 562 rovinjske obitelji bilo 250 onih koje su došle iz drugih krajeva (Benussi 2004 [1888]: 123).

Brak na istarski način ili brak kao brat i sestra, napisat će 1970. godine Lujo Margetić, jedan je od najzanimljivijih pravnih instituta srednjovjekovne Istre. Razlikujemo tri vrste zajednica dobara između muža i žene:

1. zajednica stečene imovine gdje nakon prestanka braka supružnici dijele sva dobra koja su zajedno stekli,

2. zajednica pokretnina gdje u zajednicu dobara ulaze stečena dobra i sve ostale pokretnine,

3. univerzalna zajednica dobara.

Do 1970. godine osnovnu karakteristiku braka na istarski, tumačili su povjesničari, činila je upravo univerzalna zajednica dobara muža i žene, što je podrazumijevalo da supružnici nemaju nikakve aktivne ni pasivne odvojene imovine, već sve što steknu i na

${ }^{61}$ Židovske su radnice u Solunu na početku 20. stoljeća imale sličnu sudbinu. Potražnja za radnom snagom u duhanskoj industriji je bila u stalnom rastu proporcionalnom želji za profitom, a koji je u ženama vidio prvenstveno niske dnevnice. Ženski se rad unutar židovske zajednice razvijenog Soluna smatrao produženjem njezinih kućanskih aktivnosti i imao se provoditi pod budnim okom obitelji. Posebno je važno istaknuti da je rad u duhanskoj industriji, ili barem onaj dio procesa koji su radile žene, smatran nedostojnim. Djevojke su po 14-16 sati sjedile na podu (na ladino jeziku embasho - na podu i basho - nedostojan, needuciran) radeći, utjelovljujući istovremeno nižeklasni identitet (Hadar 2007: 129). 
što se obvežu važi za zajednicu u cjelini. Posebno je zanimljivo stajalište Inchiostrija da pritom nije riječ isključivo o materijalnim dobrima već i o obavezama, pravima, aktivnostima i nadama u bolju budućnost (Margetić 1970: 281-282, 284). Međutim, detaljnom analizom istarskih statuta koji propisuju brak na istarski (Grožnjan, Dvigrad, Rovinj, Piran, Novigrad - da nabrojimo neke), Margetić je ustanovio da je univerzalnost zajednice dobara krivo tumačena te da se razlikovna karakteristika braka na istarski način ogleda prije svega u činjenici da supružnici zajednički upravljaju imovinom za vrijeme braka (iako svatko zadržava vlasništvo nad svojim dijelom), a nakon prestanka braka (u slučaju smrti jednog od supružnika) preživjeli bračni partner može ostvariti pravo na polovicu imovine onog preminulog (ibid.: 301). Rovinjski statut (glava 78) jasno definira da se temeljem starog istarskog običaja u Rovinju ima sklapati brak koji se razumije kao brak između "brata i sestre" i pritom podrazumijeva "univerzalno vlasništvo svih dobara, te dijeljena prava i aktivnosti (obaveze)". Dodatak tome je obaveza žena da snose dugove supružnika, a s obzirom na to da, kako statut navodi, “žele sudjelovati u vlasništvu dobara” (glava 65). Margetić objašnjava da jedino u Dvigradskom i Rovinjskom statutu nalazimo odredbu po kojoj muževljevi dugovi obvezuju i ženu ako su ti dugovi učinjeni za zajedničku korist. Također, zaključuje da brak na istarski način u većini slučajeva štiti supružnike od jednostranog nerazumnog obvezivanja i zaduživanja, i to propisom da bez privole supružnika ni žena ni muškarac ne mogu stvarati dugove (ibid.: 289). Pojam "univerzalna" u sintagmi univerzalna zajednica dobara nije jednoznačan, odnosno dvojben je način na koji su taj termin koristili rovinjski pravnici 16. stoljeća. Margetić na temelju statuta i praksi izdvaja karakteristike pravnoga jezika i upućuje na razumijevanje braka na istarski način kao zajednice u kojoj supružnici zadržavaju vlasništvo nad svojim dobrima, ali zajednički njima upravljaju te dijele odgovornost za poslovne odluke. Ono što je ključno za žensku poziciju je to da po smrti supruga ženi, osim njezina udjela (najčešće miraza, a ranije uz miraz je i basadego), ${ }^{62}$ pripada i polovina suprugove imovine. Mletački i slavenski brak

\footnotetext{
${ }^{62}$ Analizom najstarijih matičnih knjiga Rovinja iz druge polovice 16. stoljeća i prve polovice 17. stoljeća saznajemo da “pored 'klasičnih' podataka koje matične knjige vjenčanih sadrže, rovinjska matična knjiga vjenčanih za navedeno razdoblje sadrži i važan podatak o iznosu vjenčanoga dara ili basadega, što omogućava praćenje mnogih aspekata društvenoga života toga vremena" (Mogorović Crljenko i Doblanović 2015: 246). "Sva tri tipa braka, onaj na istarski, na mletački i na slavenski način, poznavali su darove kojima je prilikom udaje žena bila darivana. Ti su darovi bili miraz (dos, dote), uzmirazje (contradote) i vjenčani dar (basadego). Miraz je žena dobivala od svojih roditelja, odnosno od svoje obitelji, uzmirazje od muževljeve obitelji, a vjenčani dar odnosno basadego od svoga zaručnika prilikom
} 
ženu ne štite nakon suprugove smrti. Zašto je to važno? Žena nije samostalno poslovno aktivna (osim u vrlo rijetkim slučajevima) što znači da u zreloj dobi (po ženidbi) ne može steći (privatno) vlasništvo izvan okvira obiteljske imovine. Kao djevojčica ovisi o ocu te se njezina eventualna zarada također stapa s obiteljskom imovinom, a miraz za one najsiromašnije znači tek nekoliko odjevnih predmeta, odnosno kućni tekstil i manje pokretnine. Kada bi nasljeđivale isključivo svoje vlasništvo koje su unijele u brak, one bi se nalazile u zaista teškoj poziciji. Ovim pravom, žena je postajala vlasnicom polovice kuće te je suprugovi rođaci, ni djeca, nisu mogli izbaciti. Stoljetna sigurnost koju je brak na istarski način omogućavao ženi jačala je ne samo žensku društvenu i obiteljsku ulogu već i njezinu samosvijest.

Za sagledavanje društvenog specifikuma kojim se ovaj rad bavi porijeklo takve zajednice bit će jednako važno kao i sama institucija braka na istarski način. Naime, unatoč brojnim teorijama, Margetić navodi da je zasad općeprihvaćeno da se porijeklo ove institucije može tražiti u "autonomnom razvoju običajnog prava na istarskom pravnom području, koje je imalo svoje početne, prvobitne korijene u široko rasprostranjenim koncepcijama vulgarnog prava iz vremena posljednjih stoljeća rimskog carstva i prvih stoljeća srednjeg vijeka, a svoje društveno-ekonomske preduvjete u siromaštvu srednjovjekovne Istre, koje je isključivalo primjenu principa rimskog prava odvojenosti imovine bračnih drugova i osiguravanja ženine budućnosti putem miraza i uzmirazja” (ibid. : 283). Usporedimo li s ovime tvrdnju Mogorović

samoga vjenčanja. Naziv basadego, koji se u izvorima spominje i pojavljuje u različitim varijantama, dolazi od latinske riječi basium i označava poljubac odnosno, rečeno Margetićevim riječima, 'uzimanje zaručnice u posjed'. Tijekom ranoga novog vijeka posljednja su se dva dara, dakle uzmirazje i basadego, stopila u jedan dar" (ibid.: 257). "Promatrana Matična knjiga vjenčanih pokazuje da se basadego najčešće davao u novcu, čak u 92,4\% slučajeva, i to među svim društvenim slojevima i stanovništvom različitih provenijencija. Basadego u naturi zastupljen je s 5,9\%, dok se tek u $0,5 \%$ slučajeva spominje da za basadego nije dano ništa" (ibid.: 258). "Iznos basadega nerijetko pokazuje i pripadnost određenome društvenom sloju, kako darivatelja odnosno ženika, tako i nevjeste koja prima dar, a mogu svjedočiti i o provenijenciji” (ibid.: 260). Kada se govori o novčanim iznosima, darovi su najčešće iznosili između 5 i 10 dukata. "Za ilustraciju vrijednosti dukata navedimo da se 1619. godine u Rovinju za deset dukata moglo kupiti trideset kokoši, a za pet dukata slamnati krevet s jastukom (un leto depiuma dei cavazzali et un paiarizzo)" (ibid.: 258). "Osim dara u novcu, kako smo već spomenuli, davao se i dar u naturi. U naturi se davala obuća (scarpe, zoccoli...), odjeća (vestura, pelizza, calze...), tkanina (sarza), nakit (manili, manize, fede, perosini), životinje (castrato, castrone, pecore, granceole, mussoli), obrađena zemljišta (maslinici, vinogradi), poljoprivredni plodovi (10 mezene di formenton, vino). Od spomenutih se darova najviše davala tkanina - sarza i to u čak 42,46\% slučajeva. Sarza je bila posebna vrsta čvršće tkanine. Osim spomenute tkanine u većemu se postotku kao vjenčani dar davala obuća (15,06\%) i odjeća $(19,17 \%)$, dok su se ostale spomenute stvari poput nakita, životinja, zemljišta i slično davale u malenome postotku (oko pet posto)" (ibid.: 260-261). 
Crljenko da su siromašnije žene bile slobodnije, moći ćemo povezati razvoj liberalnijih i pravednijih praksi s nižim ekonomskim statusom stanovništva. S obzirom na veliko siromaštvo, podsjetimo Rovinj nema plemićkih kuća, a nadaleko je i danas poznat kao “popolana del mare" / "pučanka mora”, muž i žena su zajedno morali iznaći strategije preživljavanja koje su nadilazile artificijelne, društveno uvjetovane podjele moći. Odbacujući, dakle, tezu o njegovu izvorištu u rimskom, langobardskom i franačkom pravu, Margetić nudi novi pogled na pitanje porijekla braka na istarski način i nalazi ga u bizantinskom pravu, odnosno u Eklogi. ${ }^{63}$ Prema njezinim propisima ukupna imovina bračnih partnera smatra se zajedničkom, pri čemu pod zajedničkom imovinom treba razumjeti samo zajednicu upravljanja, a ne jedinstvenu fizičku imovinu nad kojom bi bračni drugovi imali vlasništvo u idealnim dijelovima (ibid.: 306). S obzirom na to da Margetić navodi i druge specifikume krčkog, riječkog i tršćanskog braka u odnosu na istarski, zaključit ćemo da je brak na istarski način moguće rezultat "autonomnog razvoja običajnog prava" uvjetovan ojačalim multikulturalnim društvom u kojem se propisi raznih vladara stapaju s običajima domorodačkog i doseljenog stanovništva tvoreći jedinstven obrazac koji odgovara životnim uvjetima upravo tog i takvog društva. Rovinjski statut (1531. godine, u jeku mletačke uprave) navodi: "Poštujemo i hvalimo stare istarske običaje i navike, no statutarno određujemo da se svaki brak na prostoru Rovinja i okruga, ima ugovoriti, a time i legitimizirati, te da se priroda takvog ugovora između muža i žene ima smatrati brakom brata i sestre a koji se ogleda u univerzalnom vlasništvu pokretnina i nekretnina, zajedničkoj odgovornosti odluka i radnji poduzetih od dana sklapanja braka; odnosno da sva dobra, odluke i poduzete radnje budu zajedničke, osim ako posebnim ugovorom nije drugačije uređeno"64 (glava 78). Citirani

\footnotetext{
${ }^{63}$ Pravni zbornik (726. godine) iz doba cara Lava III Isaurijanca, koji je želio u pravo uvesti kršćanska načela. Ima 18 glava od čega 16 o građanskom pravu.

${ }^{64} \mathrm{Ne}$ treba nas pretjerano začuditi što se žene u Rovinjskom statutu navode vrlo rijetko. Brzom pretragom riječi uočiti ćemo da se donna spominje svega tri puta, suor (sestra na lokalnom jeziku) jedanput, sorella dva puta, femina 3 puta i madre 8 puta (jednom odnoseći se na Majku Božju). Detaljnijim čitanjem Statuta primijetit ćemo još neke odredbe koje se tiču žena. U Glavi 31. zabranjuje se uvoz stranog vina kako muškarcima tako i ženama, domaćima i strancima. Iznimku čine starci (stariji od 70 godina) i trudnice, koji mogu uvesti slatko vino, ali pod uvjetom da plate porez. U Glavi 37. svakom muškarcu i ženi naplatit će se kazna ako unište vinograd ili drugu zasađenu površinu. U Glavi 41. opominju se svi muškarci i žene koje bi se zateklo da prodaju grožđe ili drugo voće i povrće na Trgu ili gdjegod drugdje, a da ti proizvodi nisu plod njihovih vlastitih polja. U Glavi 54. se zabranjuje konkubinat, u Glavi 56. žena se spominje u kontekstu preljuba. Dokaže li se ženi preljub, mora biti kažnjena oduzimanjem miraza, sve svoje imovine i skrbništva nad djecom. Jednako, ako se muškarcu dokaže preljub, bit će bičevan i protjeran iz Rovinja, a sva njegova dobra imaju pripasti prvoj ženi. U Glavi 57. zabranjuje se nastanjivanje prostitutki na području grada. Tko im bude omogućio stanovanje, bit će kažnjen sa 100 lira.
} 
odlomak jasno upućuje na to da je običajno pravo toliko jako da ga i mletačka uprava priznaje i hvali, te ga uvodi u općinski pravni poredak statutom.

\section{5. Uloga i pozicija žena u 19. stoljeću: intersekcijska analiza poslovne sposobnosti žena na temelju primarnih povijesnih izvora}

Metoda intersekcijske analize nije strogo utvrđena s namjerom, jer takva analiza mora biti fleksibilna i kontekstualno specifična (Hunting 2014: 13).

\section{5. 1. O izvorima i kako ih situirati}

Dosad sam kroz povijesnu perspektivu predstavila sekundarne izvore, dakle istraživanja povjesničara koji nam donose sliku o rovinjskoj ekonomiji, a s obzirom na nedostatak podataka o ženskoj ekonomiji na užem rovinjskom području, za potrebe komparacije i boljeg razumijevanja društveno-poslovnog položaja žena prije industrijalizacije, uključila sam $\mathrm{i}$ radove o poslovnoj sposobnosti žena $\mathrm{u}$ Istri $\mathrm{i}$ međurječju Drave i Save.

Premda istraživanja poslovne sposobnosti istarskih žena u 15. i 16. stoljeću postoje u naznakama, kako je ranije prikazano u radovima Marije Mogorović Crljenko, a sporedno i u onima Marina Budicina, Danijele Doblanović i Darje Mihelič, nijedan se od povijesnih radova nije detaljnije bavio ženskim poslovnim statusom u 19. stoljeću koji je od interesa za ovaj rad. Svojevrsni sažetak statusa žena u dosad promatranom periodu (petostoljetna mletačka vladavina Istrom) bio bi da su bile ekonomski aktivne, iako društveno ograničene, a u povijesnim izvorima društveno određene tek kao majke, sestre ili nevjeste te da im je pravna institucija braka na istarski način osiguravala kakvu-takvu sigurnost nakon suprugove smrti. Da bih prikazala društveno povijesni kontekst koji je prethodio industrijalizaciji Rovinja i stanje na samim počecima industrijalizacije te perspektivu koju ona donosi rovinjskim ženama morala sam, $\mathrm{u}$ nedostatku drugog materijala, analizirati odabrane primarne izvore s kraja 19. i početka

Iz navedenih je primjera razvidno da se poslovna sposobnost žene ograničava na poljoprivredu $i$ to ne podrazumijeva ženu kao vlasnicu zemlje, već eventualno prodaju njezina vlastitog uroda. Prema izjavi jedne od kazivačica, rovinjske žene, za razliku od žena zapadne jadranske obale, nisu sudjelovale u ribarskim aktivnostima ni u sakupljanju školjaka. 
20. stoljeća. Na tu ću građu, kako je ranije najavljeno, aplicirati intersekcijsku analizu. S obzirom na skromnost javno dostupnih izvora, ta je analiza tek na razini osnovnih obrisa, ali, kao što će se vidjeti, iz nje je moguće iščitati status i položaj žena u tom razdoblju. Hipoteza od koje sam krenula jest da je žena i nadalje poslovno nevidljiva u povijesnim izvorima, ponajprije zbog androcentrične patrijarhalne gradske uprave koja propisuje rubrike u matičnim knjigama.

Nevidljivost žena kao relevantnih akterki i u novim ekonomskim prilikama tumačim kao žilavost društvenog konstrukta kojim se teži održavanju moći; negdje one patrijarhalne, drugdje kapitalističke, a najčešće obje. Da bih to pokazala, osim rodnog elementa, uvodim gdje god je moguće i klasni intersekcijski element, koji je, međutim, uvjetovan podrijetlom (nacionalnošću). Jednostavnije rečeno, kada žene konačno postanu "vidljiv" dio radničke klase, tada se aktivira treći intersekcijski element naše analize, nacionalnost. Pokazat ću u kojim su zanimanjima zastupljene lokalne djevojke, a u kojima sve brojnije "strankinje".

Prvi je cilj analize potpunije saznavanje o marginalnoj poziciji žena u društvu kroz prizmu poslovne aktivnosti. Drugi cilj je sagledavanje promjena koje se događaju na razini matičnih knjiga, a na koje moguće utječe i razvoj industrije. Naime, industrija doprinosi ne samo istupu žena u javnom, radnom, životu već i njihovu uključivanju u pravne akte, dokazujući tezu da su tek poslovno aktivni građani oni koji pravno imaju društveni status.

"Matične knjige izvorno su javne isprave koje imaju zadatak da pravovaljano dokazuju činjenice koje bilježe, a to su prvenstveno: rođenje, vjenčanje i smrt. Zbog te svoje pravne snage predstavljaju pouzdan izvor za razne grane znanosti. One sadrže podatke o broju stanovnika, natalitetu, mortalitetu, migracionim kretanjima, imovinskoj, socijalnoj i konfesionalnoj strukturi pučanstva. Pružaju podatke o prosječnom životnom vijeku, smrtnosti novorođenčadi, etničkom sastavu stanovništva. Povjesničari će često u njima potražiti podatke o pojedinim ličnostima, a oni koji se bave poviješću medicine podatke o uzrocima smrti, epidemijama. Etnolozima pored ostalog pružaju indirektne informacije o običajima u vezi s izborom bračnih drugova, kumova, davanja imena djetetu. Onomastičar tu može, na temelju zabilježenih antroponima, doći do podataka o 
jezičnoj i dijalektalnoj pripadnosti stanovnika dotičnog kraja i sl.” (Vlahov 1993: 277). Po definiranju matičnih knjiga i svih vrlina kojima takvi dokumenti raspolažu, podastrijet ću rezultate analize dostupnih relevantnih matičnih knjiga. Kako je navedeno u izvorima, konzultirala sam matične knjige iz perioda od 1816. do 1890. godine (knjiga rođenih), od 1825. do 1907. godine (knjiga vjenčanih) i od 1836. do 1913. godine (knjiga umrlih). ${ }^{65}$ Takav se odabir dijelom se tiče pitanja zaštite osobnih podataka, ali se prije svega temelji na mojoj osobnoj procjeni da je taj period ključan za razumijevanje promjena društvenog statusa žena uslijed snažne industrijalizacije, a koje se reflektiraju u javnim ispravama.

Vlahov donosi sistematičan pregled značaja i razvoja matičnih knjiga koji nam omogućava da njihovu produkciju smjestimo u određeni društveno-politički, povijesni i religiozni kontekst. Preteče matičnih knjiga su crkvene evidencije koje sežu do 3. st. n. e. Mogorović Crljenko i Doblanović napominju kako su rovinjske matične knjige izvrsno očuvane, a najstarija (knjiga umrlih) datira u 1553. godinu, dakle postojala je i prije završetka Tridentskog koncila koji na razini Katoličke crkve donosi konačnu odredbu o obavezi vođenja knjiga krštenih (rođenih) i vjenčanih (usp. Vlahov 1993: 278-279; Mogorović Crljenko i Doblanović 2015: 246). Rovinj čuva i najstariju istarsku knjigu vjenčanih, koja datira u 1564. godinu (Vlahov 1993: 283). Rimskim obrednikom iz 1614. godine Katolička crkva upotpunjuje odredbu Tridentskog koncila te se uvodi obaveza vođenja knjiga umrlih i "Status animarum". Civilne se vlasti interesiraju za vođenje matičnih knjiga najprije u Francuskoj, da bi na razini Habsburške Monarhije, Patentom cara Josipa II, 1784. godine započelo razdoblje vođenja državnih matičnih knjiga (ibid.: 280).

Činjenicu da su te knjige puno urednije od onih prethodnih dugujemo upravo tom patentu kojim je utvrđeno da se:

- u matice krštenih upisuje: datum, mjesto rođenja, ime djeteta, vjera, spol, zakonito ili nezakonito, roditelji i kumovi. Za roditelje se upisivalo ime i prezime te zanimanje, ime i djevojačko prezime majke, isto tako i za kumove ime i prezime te zanimanje;

- u knjige vjenčanih upisuje: godina, mjesec i dan vjenčanja, kućni broj, prezime i ime

${ }^{65}$ Sve su navedene knjige dostupne online preko portala familysearch.org. 
ženika, vjera, dob, slobodan ili udovac, ime i prezime nevjeste (mladenke), vjera, starost, ime i prezime te zanimanje kumova;

- za knjige umrlih upisuje: godina, mjesec i dan smrti, kućni broj, ime, vjera, spol i dob.

Dekretom dvorske pisarne od 24. listopada 1788. dodana je rubrika - bolest ili uzrok smrti (ibid.).

Iz analize rubrika povjesničara Dražena Vlahova uočit ćemo da je Patentom iz 1784. godine ${ }^{66}$ propisano da se $u$ maticu krštenih ima upisivati zanimanje roditelja (množina) i kumova, u knjigu vjenčanih zanimanje kumova, a u knjizi umrlih nije predviđena rubrika o zanimanju. Ako se prisjetimo istraživanja koje je povjesničar Jakov Jelinčić proveo u Vodnjanu na temelju knjige umrlih (1815.-1893.), uočit ćemo da su župnici revnosno bilježili podatke o zanimanju gotovo svakog muškarca (Jelinčić 2006: 554). Očigledno je taj podatak bio iznimno važan na razini lokalne zajednice. Isto se ne može reći za žene s obzirom na to da se spominje samo zanimanje služavke (ibid.).

\section{5. 2. Matične knjige rođenih}

(1816.-1862.)

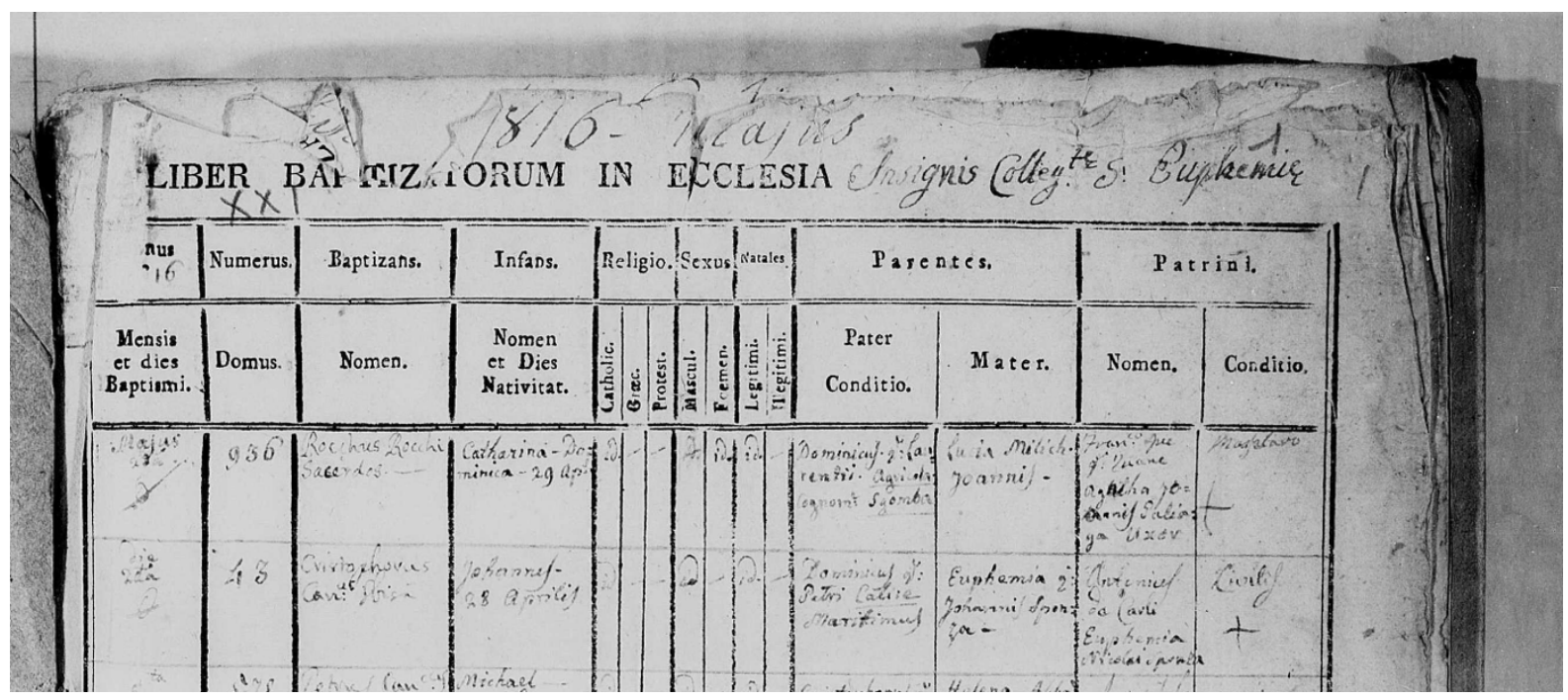

Slika 1. Rubrike matične knjige rođenih iz 1816. godine

IZVOR: familysearch.org, pristup 20. 11. 2019.

66 Govorimo, dakle, o periodu nerazvijene industrije na razini Monarhije, kada su žene još uvijek, temeljem ranijih analiza, dokazano ekonomski nevidljive u javnim spisima. 
Vlahov navodi što bi prema Patentu cara Josipa II. trebala sadržavati knjiga rođenih. Iz rubrika na Slici 1. vidljivo je da se u rovinjske knjige rođenih očekivalo unošenje svih obaveznih podataka. Pored imena oca stoji rubrika conditio, što bi u doslovnom prijevodu s latinskog značilo status. Upisivao se, dakle, društveni status oca i kuma (muškaraca). U praksi je to značilo navođenje zanimanja, osim u slučaju plemića, kojima se tada posebno isticao plemićki status (nobilis), ili građana (civitas). To bi ukratko značilo da se društveni status osobe određivao prema njezinu zanimanju. Za majke se, kao što vidimo, ne traži conditio, što bi značilo da one nemaju društveni status, nemaju zanimanje, a ne upisuje se ni jesu li plemkinje ili građanke. Konačno, to upućuje na to da su žene ograničene na društvene uloge majke, sestre, kćerke. U tim ranijim periodima za ženu se čak ne spominje ni status kućanice, koji se očigledno tada, kao ni sada, ne percipira društvenom ulogom u užem smislu riječi. Osim toga, knjige rođenih datirane u rano 19. stoljeće ne uključuju ni zanimanje majke. Međutim, od lipnja 1827. godine knjiga dobiva novu rubriku: obstetrix (primalja). Primalje su u $100 \%$ pregledanih slučajeva žene. Iako se povremeno i ranije nalaze navodi o primaljama, njihovo je spominjanje isključivo ovisilo o senzibilitetu upisivača podataka, a nerijetko je bilo povezano s funkcijom babice kao svjedokinje.

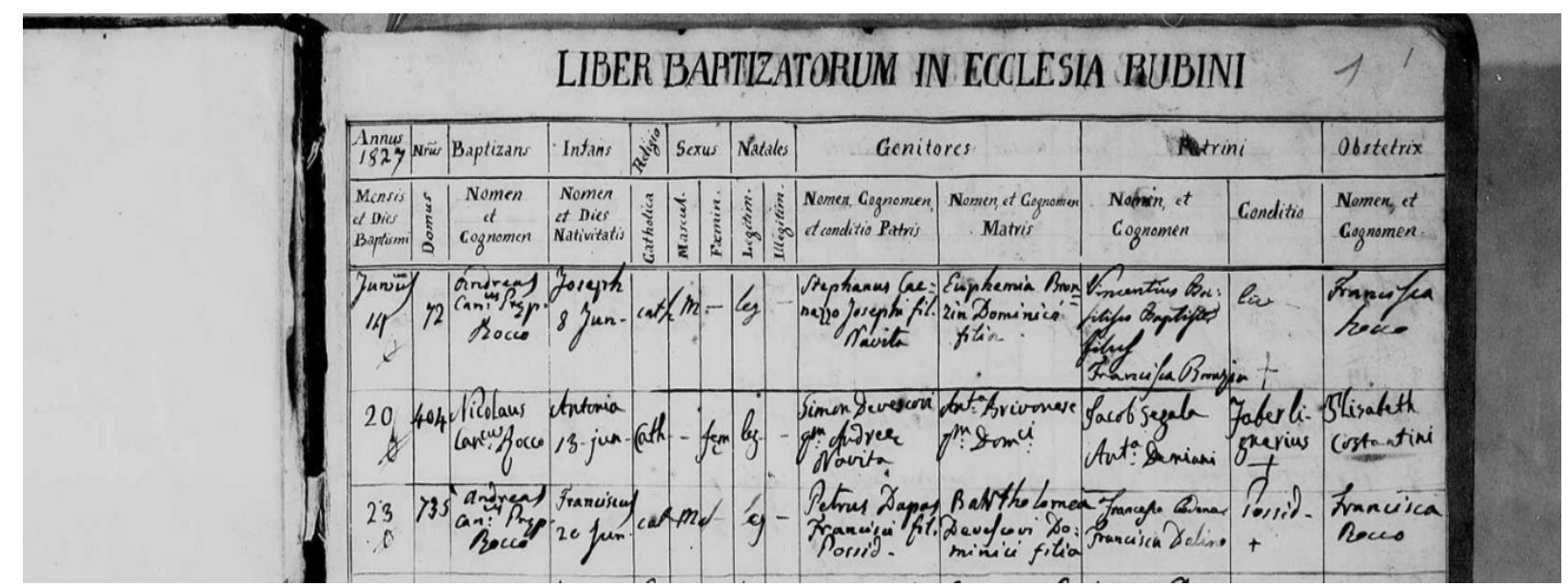

Slika 2. Rubrika za primalje, knjiga rođenih, lipanj 1827. godine

IZVOR: familysearch.org, pristup 20. 11. 2019.

Možemo još jednom zaključiti da iako u devetnaestostoljetnom Rovinju (a vjerojatno i puno ranije) postoje ženska zanimanja, ona su sustavno ignorirana čemu 
svjedoči činjenica da se u javnim spisima, poput matičnih knjiga, a koji imaju za cilj “pravovaljano dokazati činjenice koje bilježe” (Vlahov 1993), pored muškarca poljoprivrednika navodi samo ime njegove žene, no ne i podatak da je žena poljoprivrednica ili trgovkinja obiteljskim poljoprivrednim proizvodima (kao što je često, vidjeli smo, bio slučaj).

(1863.-1890.)

U poglavlju o ekonomskoj povijesti Rovinja naglasili smo kako se od 1847 . godine naovamo u Rovinju razvija industrija. Posebno su značajne 1872. godina kao godina utemeljenja Tvornice duhana Rovinj i 1882. godina kao godina utemeljenja Tvornice za preradu ribe. Upravo sam zato posegnula i za kasnijim knjigama rođenih/krštenih, ne bih li ukazala da majke nisu samo majke nego i radnice, aktivne u društvenom životu zajednice, a s obzirom na to da je riječ o godinama kada već više od 800 žena radi u tvorničkim pogonima. Govorimo o gotovo četvrtini radno aktivnog stanovništva (ako brojimo primarni sektor), odnosno polovini ako računamo samo industriju i obrt.

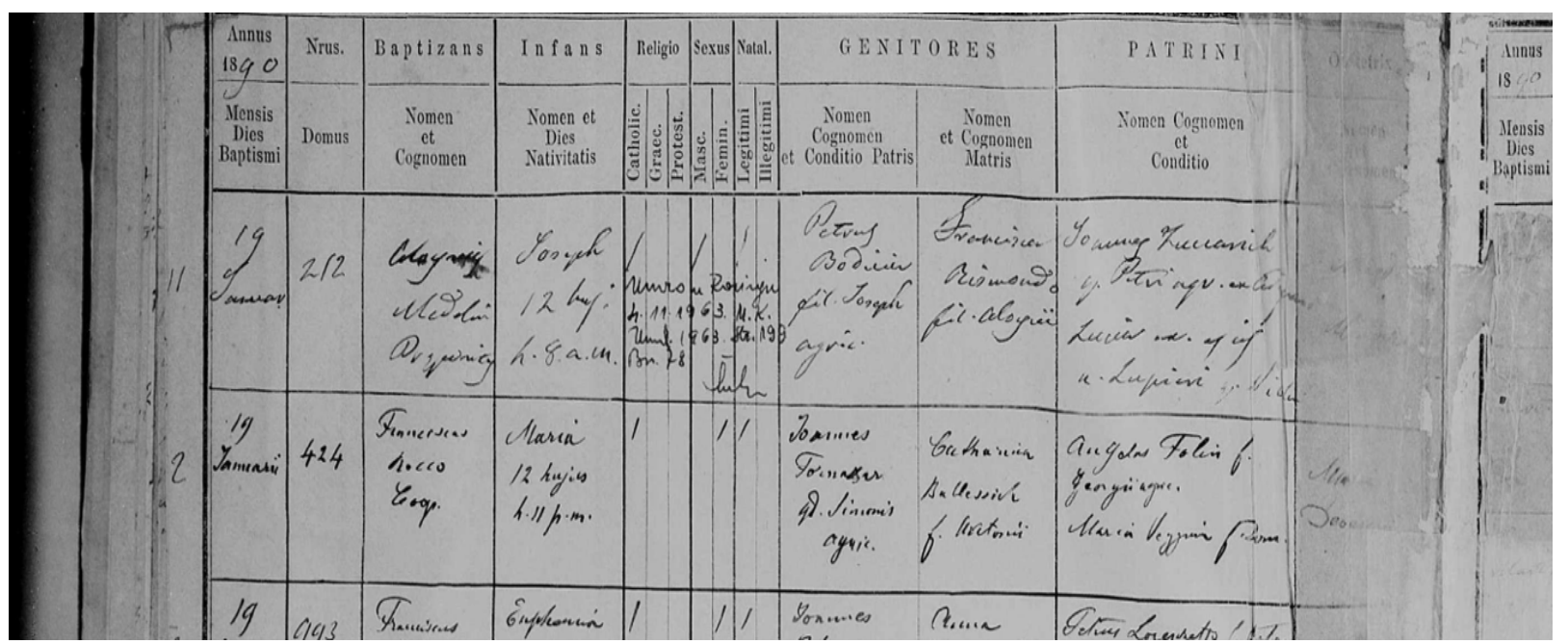

Slika 3. Rubrike matične knjige rođenih iz 1890. godine

IZVOR: familysearch.org, pristup 20. 11. 2019.

Međutim, ni krajem 19. stoljeća, u punom razvojnom jeku “ženskih” tvornica, u javnim spisima nema spomena zanimanja majke krštenog djeteta. Također, s vremenom je izostavljena rubrika kume te se sada navodi samo kum. Zanimanja koja se spominju za godine 1816., 1827., 1851. i 1890. su: marittimus (pomorac), agriocla 
(poljoprivrednik), piscator (ribar), murator (zidar), navita/nauta (pomorac na jedrenjaku), civilis (građanin), mercator (trgovac), possidens (posjednik), faber (kovač), faber navalis (brodograditelj), sutor (stolar) i auritex (zlatar). Sva ova zanimanja pojavljuju se tokom čitavog stoljeća, s time što 1827. godine, osim već spomenute rubrike primalja, ${ }^{67}$ iznimno nalazimo tri caffettiera (vlasnika kafea), barbiera (brijača) i magistru (učiteljicu) - Giuseppinu Monfalcon. Činjenica da svećenik navodi njezino zanimanje iako to pripadajućom rubrikom kume nije predviđeno, govori u prilog značaju te učiteljice za zajednicu. Godine 1851. spominju se calzolaio (postolar) i maestra (učiteljica), no nije jasno je li zaista riječ o školskoj učiteljici ili o voditeljici radnica u tvornicama, koju su radnice nazivale upravo maestra. Godine 1890. uz navedena zanimanja spominje se i machinista (mehaničar), moguće zaposlen upravo $\mathrm{u}$ novootvorenim tvorničkim pogonima. Zanimljivo je da 1823., a ponovno 1827. godine nailazimo i na tri studensa (studenta) koji figuriraju kao kumovi. Kako vrijeme odmiče, zanimanja se sve rjeđe spominju pa se tako već od 1851. godine rijetko navodi zanimanje kuma, a od 1890. gotovo nikako.

Zašto je važno osvijestiti da se u matičnim knjigama rođenih sve do 1890. godine žene nalaze u subordiniranoj poziciji. Kada sam se u razgovoru s jednom kazivačicom ${ }^{68}$ dotakla teme njezinih kćeri, hladnim mi je glasom ispričala na koji se način porodila. Govorimo o 1950-im godinama, kada su žene još uvijek redovito rađale kod kuće. Prisjetila se kako je drugu kćer rodila na gornjem katu, dok je starije dijete bilo samo u prizemlju. Suprug je bio u lovu i iako mu je najavila bolove, smatrao je da nema potrebe da dolazi kući. Ona je još tog jutra radila u polju. Kazivačica nije pokazivala osjećaje ljutnje, tuge ili suosjećanja prema djeci koja, jednako kao ni ona, nisu uživala podršku u teškim trenucima. Ta otupljenost na bol postala je u mom istraživanju sinonim za žene. One su radile, rađale, pokapale djecu i trpjele kao da se to podrazumijeva. Osim ovog kazivanja, gotovo je svaki razgovor s radnicama donosio neku tešku priču o zlostavljanju, nemogućnosti kvalitetne brige o djeci, cjelodnevnom radu, niskim plaćama ili narušenom zdravlju uslijed loših uvjeta rada. Kada u analizi

${ }^{67}$ 1827. godine: Domenica Benussi, Francesca Rocco, Elisabetta Costantini, Antonia Veggian; 1851. godine: Domenica Benussi, Maria Costantini, Benvenuta Spongia, Aloysia Barzelogna; 1863. godine: Maria Costantini i Eufemia Ive; 1890. godine: Maria Benussi, Clara Zulian, Maria Dandolo.

${ }^{68}$ (M. I. 1930.). 
knjige rođenih vidimo da majka nije ona koja se prva navodi uz dijete, već je tu radi čiste statistike i pravnih pitanja, naša je dužnost da tu činjenicu ponajprije osvijestimo, a tada i stavimo u kontekst perpetuirano sekundarne pozicije žena, čak i u slučajevima gdje je njihova uloga primarna - uloga roditeljice. Teorije spola dugi su niz godina razliku u statusu muškaraca i žena objašnjavale prirodnim, biološkim determinantama. Žene su u tom kontekstu najprije zadovoljavale reproduktivnu funkciju, a muškarci produktivnu. Time se pravdala sekundarna društvena pozicija žena jer je, naime, ženska domena "zahvaljujući" njezinim prirodnim karakteristikama ona privatna. Međutim, povijesni podaci pokazuju da žene nisu bile isključivo orijentirane na kućanstvo, već su značajno doprinosile ekonomskoj stabilnosti zajednice. Pravni javni spisi upućuju na to da su žene ekonomski nevidljive na razini društvenog miljea, no sada možemo ustanoviti da se u tim istim spisima subordinira i njihova "primarna” uloga majke. Strategije te subordinacije jasno se vide u samoj formulaciju rubrika te naknadnim kontekstualiziranjem (ne)upisanih podataka.

\section{5. 3. Matične knjige umrlih}

(1836.-1913.)

Iako Vlahov (1993: 280) navodi da se matičnim knjigama umrlih ne navode zanimanja, analizom rovinjskih knjiga umrlih u periodu od 1836. do 1913. godine vidjet ćemo da pored nomen stoji i conditio (status/zanimanje). Nažalost, svećenici koji su vodili evidenciju zanimanje navode samo uz ime muškaraca i to ne redovito, nego samo u određenim godinama, dok za žene i djecu navode zanimanja njihovih očeva. Takvo se stanje zadržalo sve do 1913. godine. 


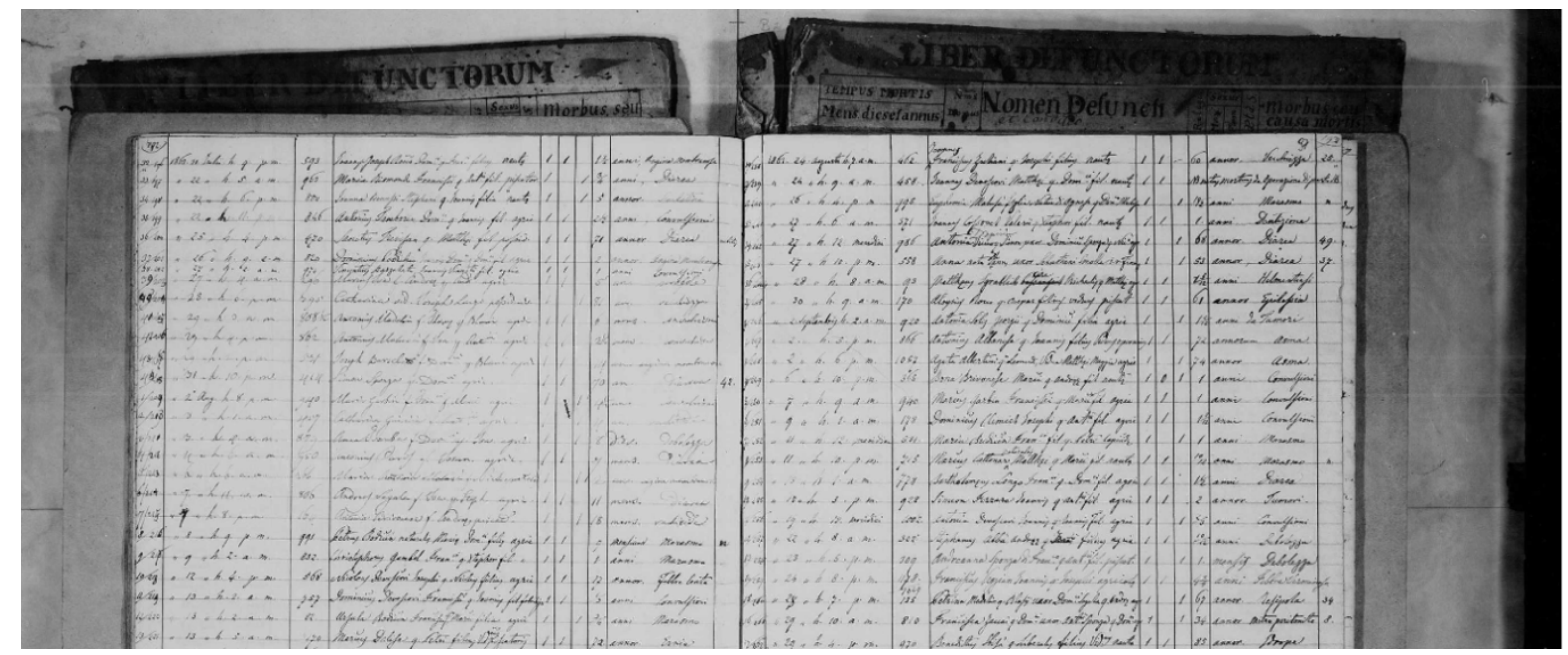

Slika 4. Matična knjiga umrlih iz 1863. godine

IZVOR: familysearch.org, pristup 20. 11. 2019.

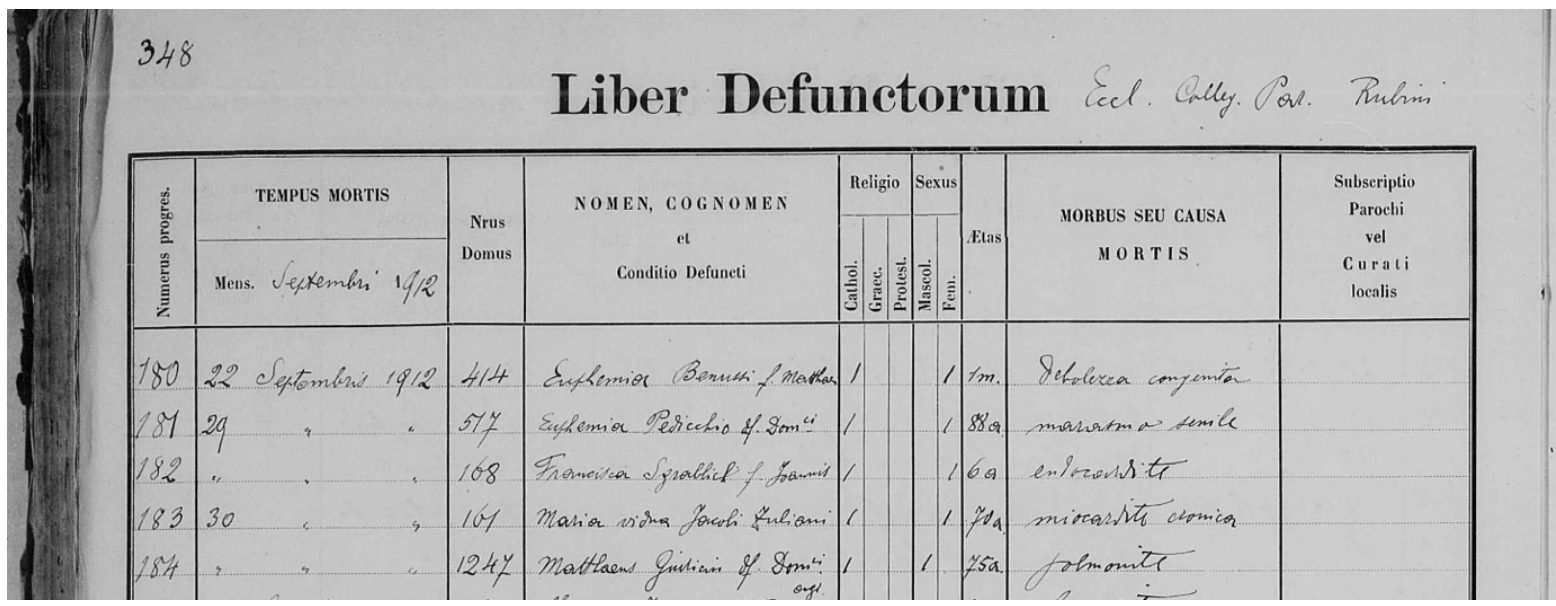

Slika 5. Matična knjiga umrlih iz 1912. godine

IZVOR: familysearch.org, pristup 20. 11. 2019.

\section{5. 4. Matične knjige vjenčanih}

(1825.-1907.)

Za razliku od matičnih knjiga rođenih, knjiga vjenčanih nema jasnu strukturu. U prvoj fazi podaci se navode u slobodnoj formi, ali kojom se uglavnom nepromjenjivim ritmom bilježe ime i prezime mladoženje, njegovo zanimanje i dob te ime i prezime i starost mlade. Zanimanja mladoženja ostaju gotovo nepromijenjena u odnosu na ranija 
razdoblja, s dodatkom zanimanja operaio (radnik u tvornici). Dalje se u tekstu navodi kako mladenci slobodnom voljom stupaju u brak, a na kraju svećenik donosi i podatak o iznosu dara kojim mladoženja daruje nevjestu.

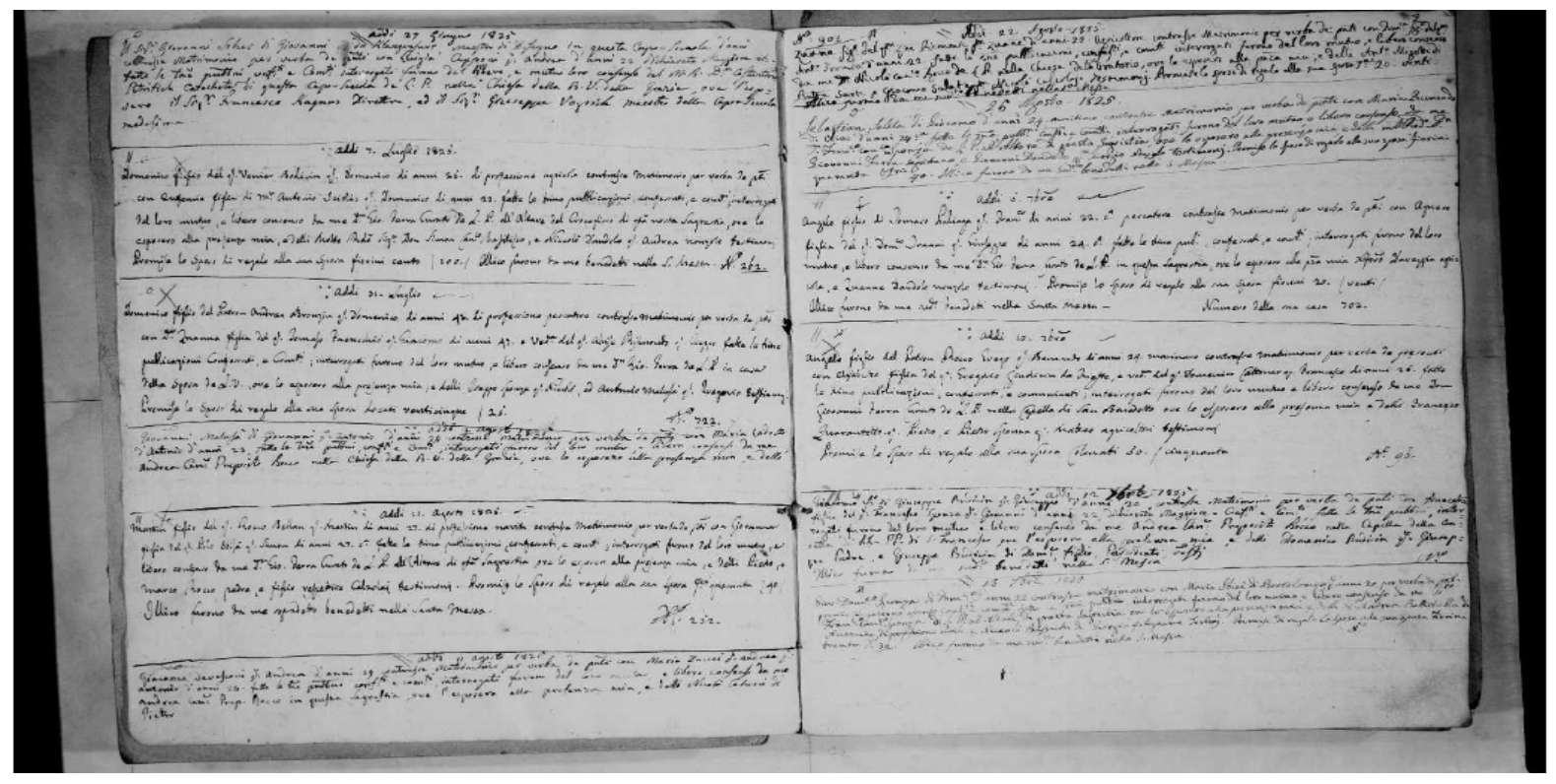

Slika 6. Matična knjiga vjenčanih iz 1825. godine IZVOR: familysearch.org, pristup 20. 11. 2019.

Godine 1859. uvodi se struktura slična onoj matičnih knjiga. Što je značajnije, prvi se put uvodi rubrika u koju se imalo upisati društveni status/zanimanje nevjeste (conditio sponsae). Poražavajuća je činjenica da se $\mathrm{u}$ tu rubriku umjesto njezina zanimanja zapravo unosilo zanimanje oca. Takav se običaj zadržao sve do 1906. godine. 


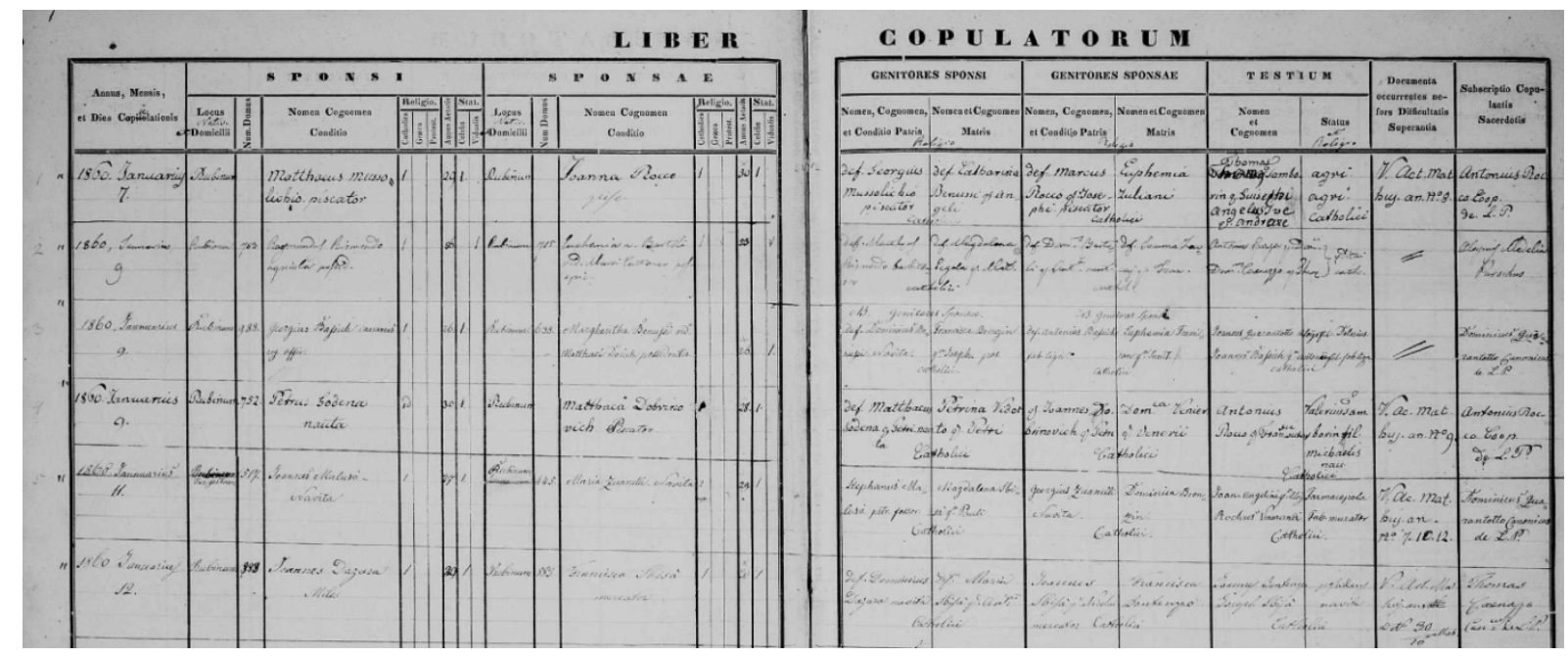

Slika 7. Matična knjiga vjenčanih iz 1860. godine

IZVOR: familysearch.org, pristup 20. 11. 2019.

Tek se tada, dakle pune 34 godine od osnivanja Tvornice, u javnim spisima spominje radnica tvornice duhana (operaia fabbrica tabacchi). Od toga dana knjige postaju bogatije za cijeli niz ženskih zanimanja. Nažalost, za ovaj su nam pregled dostupne samo knjige do 1907. godine, no sasvim je dovoljno navesti da se u tih godinu dana vjenčalo sedamdeset devet radnica tvornice duhana, dvije radnice tvornice za preradu ribe, osam krojačica, radnica u mlinu, deset služavki i radnica u praonici. Također, nerijetko nailazimo na podatak da se nevjeste identificiraju pod conditio privata. Naglašavanje "privatnog” statusa, što je podrazumijevalo status domaćice, snažno odjekuje i u današnjim okvirima kada se domaćice još uvijek nedovoljno jasno tretiraju u kontekstu poslovne sposobnosti žena. S obzirom na to da se ranije takav podatak nije navodio, moguće je da razvoj industrije i osvještavanje ženskog rada rezultiraju svojevrsnim stavom o domaćinstvu kao društvenom, odnosno poslovnom statusu žena. Žene koje se tako određuju uglavnom su Rovinjke. Prateći intersekcijsku metodologiju u analizi matičnih knjiga, iako na relativno skromnom uzorku, s obzirom na to da se status (zanimanje) žena u javnim rovinjskim spisima bilježi tek od 1906. godine, uspjela sam izdvojiti karakteristike rovinjskog poslovnog okruženja od značaja za ovaj rad. U Tvornici duhana zaposlene su uglavnom Rovinjke, uz iznimku dviju djevojaka - jedne iz Savičente, druge iz Labina. Dvije radnice Tvornice za preradu ribe koje se u tom izvoru spominju također su Rovinjke (naglasit ćemo, autohtonog, 
talijanskog podrijetla), služavke su bez iznimke "strankinje" i to iz Buja, Trgeta, Labina, Rovinjskog Sela i Lanišča, dok se među krojačicama, uz prevlast Rovinjki, spominje i radnica s područja Brtonigle.

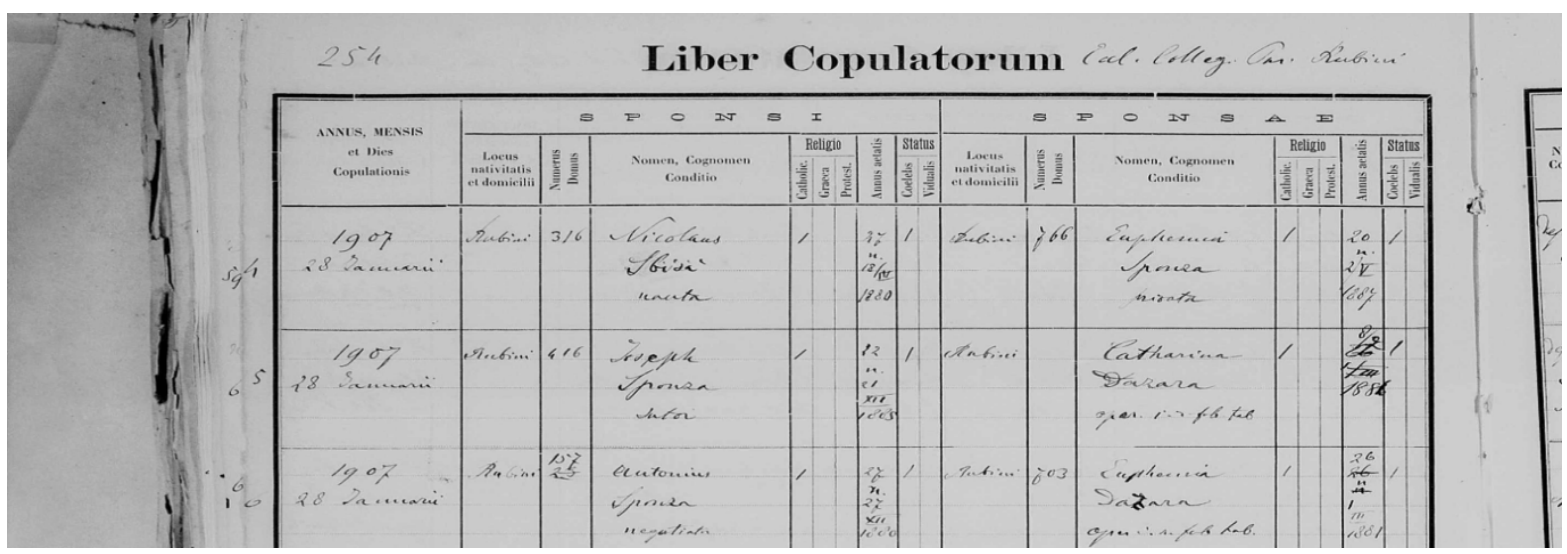

Slika 8. Matična knjiga vjenčanih iz 1907. godine

IZVOR: familysearch.org, pristup 20. 11. 2019.

\section{BITI ROVINJSKA RADNICA: intersekcijska analiza uloga $i$ položaja rovinjskih industrijskih radnica}

\section{1. Počeci rovinjskog industrijskog razvoja u svjetlu rastućeg kapitalizma}

"Šezdesetih godina devetnaestog stoljeća u ekonomskom i političkom rječniku svijeta pojavila se nova riječ: kapitalizam. (...) Bio je to trijumf društva koje je vjerovalo da se ekonomski rast zasniva na konkurentom privatnom poduzeću, na uspješnoj kupnji na najjeftinijem tržištu (što uključuje i kupnju radne snage) i prodaji na najskupljem" (Hobsbawm 1999: 9). Međutim, kritike takvog sustava koji je manifestirao snažne socijalne nepravde stigle su vrlo brzo u vidu Marxova Kapitala (1867).

U sklopu Austro-Ugarske Monarhije Rovinj je pratio globalni ekonomski razvojni put, a Krešimir Džeba će u monografiji Duhanski put u Rovinj navesti nekoliko olakotnih okolnosti koje su pripomogle upravo takvom slijedu događaja. Sklapanjem Austro-ugarske nagodbe, austrijski centralizam je razbijen, ranije širenje na 
Translajtaniju uspostavom Bachova apsolutizma (1851.-1860.) omogućilo je jačanje ugarskog dijela carstva, koje je bilo od iznimnog značaja i u kasnijoj, dvojnoj političkoj formaciji. S druge strane, raniji gubitak Lombardije i Venecije dodatno oslabljuje austrijski utjecaj. U takvoj situaciji, a s ciljem ponovnog osnaživanja duhanskog monopola uspostavljenog 1784. godine, na nerazvijenim područjima Monarhije, koja karakterizira obilje nezaposlene radne snage, otvara se čak dvanaest tvornica duhana ${ }^{69}$ (Džeba 1987: 52-54). Jedna od tih tvornica je i ona rovinjska. Kao jedan od ključnih čimbenika kapitalističkog booma druge polovice 19. stoljeća Hobsbawm vidi brojnu i jeftinu radnu snagu (Hobsbawm 1999: 32). Stoga valja pokušati smjestiti rovinjske radnice upravo u kontekst provincijalne, osiromašene zajednice u kojoj većinu stanovništva čine žene.

Analiza društveno-povijesnih i ekonomskih prilike koje su zadesile dotad muško-orijentiranu ekonomiju temeljenu na poljoprivredi, ribarstvu, pomorstvu i brodogradnji, otvara nam jasniju perspektivu u promišljanju uzroka osnivanja spomenutih tvornica. 1853. u Rovinju se gradi novi svjetionik koji prati najsuvremenije tehnološke dosege. Izgradnjom svjetionika, posao pilota ${ }^{70}$, odnosno muškaraca koji usmjeravaju brodove, izgubilo je njih 40 a nedovoljno brz prijelaz s jedrenjaka na parobrod uzrokovao je gubitak primata u pomorskoj trgovini na sjevernom Jadranu. Otegotna je okolnost bila i bolest vinove loze, koju su rovinjski seljaci, prema pisanjima Benussija, smatrali Božjom kaznom te nisu poduzimali ništa kako bi je spriječili ili izliječili. Sve je to dovelo Rovinj, a time i čitave obitelji, u vrlo tešku ekonomsku situaciju (ibid.: 234-235). Usporedimo li statističke podatke iz 1780. i 1880. godine, uvidjet ćemo drastičnu razliku. Broj stanovnika je gotovo isti, s time što je 1880. iz Rovinja emigriralo 4800 osoba od čega njih 2300 odlazi u Pulu. Ponajviše odlaze mlađi muškarci na rad u Arsenal. Godine 1880. imamo 55\% radno aktivnog stanovništva, za razliku od 37\% 1780. godine. Unutar radno aktivnog stanovništva $24 \%$ otpada na poljoprivrednike, što je gotovo isto kao i 1780 . (27\%), 10\% na prijevoz i trgovinu (morem), a 7\% na ribarstvo. Dakle, tek 17\% djelatnosti vezano je direktno uz

${ }^{69}$ 1858. otvorena je tvornica u Rijeci, 1860. u Varaždinu, 1869. u Zagrebu, 1871. u Ljubljani, 1894. u Senju, te još četiri tvornice na području Bosne i Hercegovine (Kolar-Dimitrijević 1979: 39).

70 "O pomorskoj vještini Rovinjana posebno svjedoči odluka Mletaka iz XVII. stoljeća po kojoj je svaki brod što ljeti plovi prema 'kraljici mora' obvezan pristati u Rovinju i tamo uzeti pomorskog vodiča, pilota, da bi ga sigurno doveo do odredišta (Džeba 1987:29). 
more, za razliku od 1780. godine kada je 47\% radno aktivnog stanovništva, a time i čitavih obitelji, ovisilo o pomorskoj trgovini i ribarstvu. S obzirom na gore navedene razvojno- tehnološke promjene, jasno je kako se Rovinjci nisu prilagodili novim tržišnim i tehnološkim uvjetima pomorstva, više nisu imali Veneciju kao zaštitnika na moru, a Austrija, koja nije imala drugu pomorsku tradiciju osim ratne mornarice, nije mogla snažnije razvijati pomorstvo, posebno ne ono temeljeno na jedrenjacima.

Međutim, Austrija nudi nova ekonomsko-tehnološka rješenja, ali koja impliciraju određene društvene promjene na razini svakodnevice, posebice na razini rodnih uloga.

Stanovništvo se, naime, okrenulo obrtništvu i industriji pa tako, za razliku od 1780. godine kada tek 16\% radno aktivnog stanovništva radi u sekundarnom sektoru, 1880. se obrtima i industrijom bavi njih 27\%. Očigledno je kako većinu te razlike, dakle minimalno $11 \%$ čine žene. Međutim, ako znamo da je veliki broj mladića otišao za Pulu, a da je s druge strane na isti broj stanovnika udio onog radno aktivnog narastao za $18 \%$, moguće je da žene zauzimaju upravo tih $18 \%$. Prema statističkim podacima iz 1852. godine, žene su radno aktivne i izvan uže obiteljskih djelatnosti i to: četiri žene rade $\mathrm{u}$ lokalnom hidrauličnom mlinu za masline, njih osamnaest $\mathrm{u}$ privatnim pekarama $^{71}$, pet su krčmarice i jedna je trgovkinja. Iako nezaposlene, u bilješkama Budicin spominje još osamdeset dvije žene koje tkaju za dvanaest rovinjskih tkalaca i krojača (ibid.: 436). One izvan statističkih podataka, ali sačuvane u usmenoj predaji jesu Švelje. Iako su djevojke odmalena učile šiti, plesti i vesti za vlastite potrebe, novi društveno-ekonomski okvir u kojem industrijske radnice postaju hraniteljice obitelji, otvara prostor za razvoj krojačkog obrta kao plaćenog ženskog rada. Naime, u nedostatku vremena, djevojke zaposlene u Tvornici duhana, naručivale bi izradu jednog dijela opreme za udaju, ali i druge odjevne predmete.

Vlastiti prihodi su omogućavali tabacchinama pripremu dote [miraz] koja je bila puno više od uobičajenih dva para plahti. Dapače, ponosile su se brojnim izvezenim tekstilnim predmetima za osobnu upotrebu i kućanstvo. (A. R)

\footnotetext{
71 Za vrijeme Mletačke Republike pekare su bile u vlasništvu općine. Prva privatna pekara otvorena je 1832. godine nakon čega je u narednih 30 godina uslijedilo otvaranje njih još sedam. Iako u pekarama rade isključivo žene, barem prema onome što možemo zaključiti iz statističkih podataka iz 1851., vlasnici su bili muškarci sve do 1863. godine kada u contradi la Mussa pekaru otvara Eufemia Sponza zvana Marasca (Maraska) (Budicin 1997: 437).
} 
U takvim okolnostima pojedine djevojke postaju profesionalne krojačice. Kazivanje o jednoj od najpoznatijih rovinjskih krojačica na prijelazu stoljeća oprimjeruje stav o diversificiranoj, bogatoj i prosperitetnoj ženskoj ekonomiji Rovinja zahvaljujući kojoj Rovinj možemo okarakterizirati kao jedan od hrvatskih she-towns odnosno onagradova (usp. Kolar- Dimitrijević prema Bebel 1979:39).

Eufemija Fiametta Vovcich [rođena 1891. godine] moja stara teta je bila vrsna krojačica. Jako fina žena, zlatnih ruku. Klijentice su sve bile dobrostojeće i ona se kretala u tom visokom gradskom društvu. Mislim da je imala kontakt i s barunicom Barbarom von Hütterott. Ona se držala visoko, možemo čak reći da je bila pomalo arogantna, ali s pravom jer je zaista bila nešto više u odnosu na druge žene upravo zbog tog načina ophođenja. Ona je recimo šetala sa šeširom, lijepo se odijevala, glumila je kod časnih sestara uvijek kraljicu Teodoru...Bila je vrlo autoritarna. Nije se udala, brinula je o roditeljima i kasnije o meni i bratu...sama se uzdržavala. U to vrijeme krojačice i vezilje su jako dobro radile jer tabacchine si nisu same spremale miraz nego su vezilje radile taj posao i na taj su način i one osiguravale egzistenciju svojim obiteljima. (T. L.)

Dodajmo tome da su brojne žene aktivne i u okviru obiteljskih poslova, primjerice $u$ poljoprivredi. Međutim, one čiji su muževi i očevi izgubili posao na moru (podsjetimo, pad od 30\% udjela) i čije obitelji nisu imale veća poljoprivredna dobra, bile su primorane raditi u tvornicama.

30. prosinca 1850. godine u Rovinju je formirana Gospodarska komora Istre, a već je prethodno, u tehnološkim okvirima prve industrijske revolucije, dakle na parni pogon, otvoren mlin s odjelom za pakiranje tjestenine. Godine 1852. otvorena je cementara, a 1878. voštarnica. O uvjetima za razvoj rovinjske industrije najbolje govori podatak koji nam donosi Benussi: voštarnica je 1883. proizvodila $20000 \mathrm{~kg}$ svijeća, a 1887. godine $40000 \mathrm{~kg}$. Osim što su se prodavale u Istri i Dalmaciji, svijeće su se izvozile u Štajersku, Tirol, Češku i Moravsku, dakle unutar austrougarskih granica (Benussi 2004 [1888]: 235). Bez tržišta, takva ekspanzija ne bi bila moguća.

Nastavno na te uspjehe, podest (gradonačelnik) Campitelli 1871. godine započinje potrebne radnje kako bi se tvornica duhana otvorila upravo u Rovinju. Za uspostavu tvorničkog pogona, Rovinj se natjecao s Koprom. U korist Rovinja je, navodno, presudio upravo veći broj dostupne ženske radne snage (Vlajo 1999: 36). Iz današnje perspektive ličnost Mattea Campitellija koji se bori za siromašne Rovinjke 
djeluje gotovo legendarno. U svakom povijesnom pregledu razvoja TDR-a čitat ćemo o njegovim zagovaračkim naporima da se u Rovinju otvori tvornica jer je "ovdašnje stanovništvo marljivo, a obiluje velikim brojem ženske radne snage koja potrebuje uzdržavanje" (primjerice Benussi 2004 [1888]: 235). Prvi tvornički pogon otvoren je unutar gradskih zidina u zgradi današnjeg Centra za povijesna istraživanja 16. kolovoza 1872. godine. Od samog početka pa sve do kraja I. svjetskog rata, rovinjska je tvornica bila jedna od sastavnica austrougarske Tabak-regie, državnog monopola u kojem je bila koncentrirana cjelokupna prerada i trgovina duhanom na području Carstva. Iako je rovinjska tvornica predstavljala tek kotačić u mašineriji duhanske industrije, čini se da je ipak bila od velike važnosti za državnu blagajnu (TD magazin 1997: 6-8). Osim za državnu blagajnu, zaposlenje u TDR-u je riječima kazivačice bila mana s neba ${ }^{72}$ (A. R.).

Otvorenje ovog pogona izazvalo je veliki interes kod stanovnika Rovinja. Za rad se tada predbilježilo oko 700 djevojaka, no zbog prostornih ograničenja i probne faze proizvodnje, zaposlen je samo 401 radnik. Od toga 391 su bile žena, a muškaraca je bilo svega 10; trojica su bili rukovodioci i nadzornici, a sedmorica radnici. Poražavajuća je činjenica kako su trećinu radne snage činile djevojčice mlađe od 14 godina, no iz tog podatka saznajemo i koliko je za jednu obitelj značilo zaposlenje u Tvornici (usp. Džeba 1987: 60).

72 Prema Novom zavjetu, doslovno "kruh s neba". 


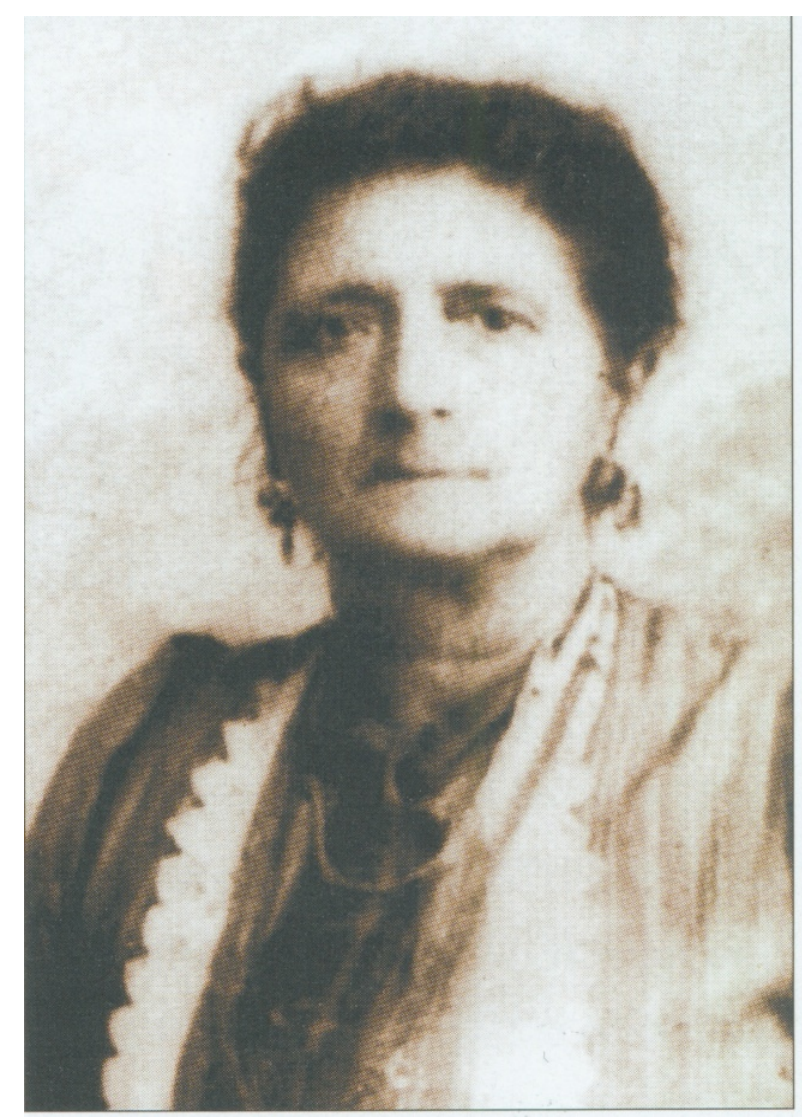

Slika 9. Giovanna Ive, jedna od prvih tabacchina koja je s radom započela $\mathrm{u}$ proizvodnom pogonu u ulici San Damiano. Ovaj je portret sama dala izradili po rođenju kćerke 1875. godine. Izradio ga je fotograf iz Milana. Uz objašnjenje fotografije uslijedio je komentar vlasnice, Giovannine praunuke, o mušičavosti tabacchina. Giovannu su naslijedile još tri generacije radnica iz iste obitelji. Privatno vlasništvo kazivačica A. D. Q. i F. Q.

Zabrana rada za maloljetnike (tada se punoljetstvo stjecalo s 14 godina) nastupila je tek 1886. godine, četrnaest godina od osnutka Tvornice, a zahvaljujući generalnim naporima za poboljšanje radničkih prava na razini Europe. Granica se podigla na 18 godina za vrijeme talijanske vladavine, no kako u svom istraživanju o istarskim rudarima navodi Matošević, uvjeti života su bili toliko loši da su roditelji falsificirali dokumente kako bi dokazali da su djeca starija i kako bi što prije počeli s radom (Matošević 2011: 226). Slično se stanje zadržava i nakon uspostave samoupravljačkog modela jugoslavenske ekonomije od 1949. dalje. Iako je zabrana zapošljavanja maloljetnika na snazi, teški uvjeti života i dobra volja pojedinih poslodavaca otvarala je put raznim strategijama preživljavanja. Kazivačica rođena $u$ 
Svetoj Mariji Magdaleni u blizini Žminja 1935. godine, teški težački život odlučila je zamijeniti samostalnim plaćenim radom još kao maloljetna. Isto je ostvarila s obzirom na urođenu snalažljivost $\mathrm{i}$ hrabrost, što će i sama u više navrata isticati; najprije odbijanjem sudjelovanja u prisilnom radu na izgradnji pruge Lupoglav-Štalije kojega se kroz smijeh prisjeća:

To je bilo bilo četrdeset sedme, osme kad su nas slali ono, baš slali...

Kad su me zvali unutra su rekli 'Mala, ideš ti na prugu?', a ja sam rekla 'Ne!'

Ča san ja stila reć, ni da iman za kopat, ni da iman za orat kao ljudi od familije ča su rekli 'Ma znate, ja ne morem, ja iman posla, ja ovako, ja onako'... Ča san ja od četrnajst lit stila reć. Ja san rekla 'Ne!' a oni 'Biži van!' (M.G.),

a zatim i u životnoj odluci da se osamostali i potraži posao izvan obiteljskog poljoprivrednog okruženja:

Kad sam pošla delo iskati znaš... teta Milka [sestra kazivačice] ona je vajk povučena bila, mi je rekla: ' Ti si mlajđa, ma snajdi se ti, forši, ti ćeš više se snać... da si najdeš delo.'

Kazivačica je s radom započela kao maloljetnica, bez ikakvih posljedica za njenu obitelj ili poslodavce.

U Poljoprivrednoj školi san bila kako kuharica na kraju 1950. i cilu 1951. 1952. sam došla za Rovinj. Eccola... Još nisam imala njanke šesnajst let, me nisu upisali šest miseci.

Zašto vas nisu upisali?

Sam bila još maloljetna.

Znači, od šesnaest godina se smjelo raditi?

Da. I kad je to izašlo van ja sam pošla lipo u Pazin po ti dokumenti iskati i su mi upisali tih šest miseci.

Unatoč činjenici da su još kao djevojčice započinjale s teškim radom $u$ duhanskoj manufakturi, rezultati su bili iznimni. Temeljem povoljnog izvještaja državnog savjetnika Merkla von Reinseea u kojem se navodi kako je zaposlen tek dio raspoložive radne snage, da su radnice marljive i odnosi plaća povoljni ${ }^{73}$, te da postoje svi izgledi za uspješan rad na izradi cigara na najmanje 50-60 stolova, 1875. godine

\footnotetext{
${ }^{73} \mathrm{U}$ duhu rastućeg kapitalizma, jasno je kako se povoljni odnosi plaća odnose na niske nadnice radnica u odnosu na produktivnost koja zarana premašuje očekivanja. Džeba nam u tom smislu donosi detaljne podatke. "Iz 224 centi duhanskih listova mlade su Rovinjanke 1872. savile 242.100 komada cigara...u stiještenim prostorijama u Ulici San Damiano gomilalo se sve više stolova i strojeva, sve je više ženskih ruku izrađivalo raznovrsne cigare (552 zaposlena 1876.). Takvim ekstenzivnim radom proizvodnja je skokovito rasla: već 1874 . izrađeno je blizu 14 milijuna cigara, gotovo dvostruko više nego prethodne godine, a slijedeće 15.973.900 komada" (Džeba 1987: 65).
} 
izgrađena je rovinjska Tvornica duhana kao jedna od najsuvremenijih tvornica tog doba, s vlastitim sustavom navodnjavanja i odvodnje, električnom energijom i parnim pogonima (Bosazzi 2012: 192). Bila je to veličanstvena zgrada izgrađena na samom rubu urbane zone. Usporedbe radi, slične ekonomske i urbanističke razvojne putanje prisutne su i izvan granica Carstva $\mathrm{i}$ onih jedanaest tvornica koje niču paralelno s rovinjskom. Naime, austrijski duhanski biznis širio se i na području Otomanskog carstva, pa krajem 19. i početkom 20. stoljeća skladišta i tvornice duhana niču diljem Soluna i Kavale. Zgrade povezane s preradom duhana postaju simboli novih industrijskih gradova, koje razvijaju podjednako Habsburško i Otomansko carstvo (Rentetzi 2008: 64). Fokusirajući se na tvorničke zgrade kao mjesta produkcije ekonomskih, diskurzivnih i kulturnih praksi, Maria Rentetzi će naglasiti ulogu arhitekture u uspostavljanju moći, novih načina proizvodnje (implicirajući i novi društveni red), te kao sredstva povećanja produktivnosti. Uređenjem vrtova i knjižnica težilo se, primjerice, privući i zadržati vješte i dobre radnike (ibid.: 65-66), a visoki stropovi i prostrane prostorije osim stvaranja dojma bogatstva i moći imali su i praktične funkcije; jedna vrata radi lakše kontrole krijumčarenja i potencijalnih pobuna radnika te otvoreni prostori salona kako bi nadglednici lakše nadgledali rad (usp. ibid.: 72). U kontekstu rovinjske tvornice, austrijska socijalna politika ogledala se u otvaranju jaslica u okrilju tvorničkog kompleksa koji je omogućavao majkama da rade i doje djecu, time zadržavajući već uhodanu i pouzdanu radnu snagu.

Ako se uzme u obzir činjenica da su kontrole i procesi regrutacije rovinjskih radnica bili vrlo strogi, da se marljivo vodila evidencija o napretku radnica, da je zgrada zadovoljavala najviše standarde tadašnje gradnje i da su radnicama zaista bili na raspolaganju neki od navedenih sadržaja koji su imali za cilj unaprijediti uvjete rada u kontekstu kapitalizma, a s time u vezi i profitom, teza koju je iznijela Rentetzi primjenjiva je i na primjer Rovinja. Priklanjajući se prihvaćenom stajalištu da su nove tvornice imale pragmatičnu i simboličnu funkciju, Rentetzi će tvornice okarakterizirati kao ikone kulture i simbole prestiža. Zaista, veličanstvenom arhitekturom Tvornica duhana Rovinj se uklapala u reprezentativni stil gradnje carsko-kraljevskog obalnog stila, obojena u žuto s drvenim kapcima, što je službenicima Duhanskog monopola omogućavalo da se diljem Carstva osjećaju kao kod kuće. Džeba će u svom povijesnom 
pregledu razvoja tvornice navesti da je tvornička zgrada u Rovinju izgrađena po načelima po kojima je Duhanski monopol podizao takva zdanja širom carstva, ali je bila smještena na najljepšoj lokaciji (Džeba 1987: 69-70). "Stupovi iz Vitkovica s ukrašenim kapitelima, nisu imali samo ulogu da podupiru svodove tvorničkih hala već $\mathrm{i}$ da istaknu poseban status radnika carskog monopola. U Rovinju je taj status posebno cijenjen, ne toliko zbog daška elegancije koji su stupovi unosili u sumorne industrijske prostore, koliko zbog ekonomskog značenja rada u tvornici za svakodnevni život" (ibid: 78). Za rovinjske radnice koje u svojim domaćinstvima nisu imal tekuće vode, električne energije ni kanalizacije, suvremeno arhitektonsko zdanje s vodoopskrbom i električnom energijom, zasigurno je ulijevalo strahopoštovanje, ali i osjećaj nadmoći nad drugim radnicama koje su radile u bijednim uvjetima (na otvorenom) ili kod onih koje su ostajale kod kuće i nisu imale mogućnost zarade u novcu.

Osim velebne arhitekture radnice je u javnom prostoru 'predstavljao' neumorni zvuk sirene. Zvuk je bio toliko glasan da se širio čitavim gradom, kako bi ga svaka radnica čula. Zvuk je bio sinonim za red i disciplinu koju je valjalo poštivati pridajući još veći značaj zaposlenju u prestižnoj tvornici. Čitav je grad bio podređen Tvornici i njenom ritmu.

Svakodnevica tabacchine bila je regulirana zvukom sirene koji ih je pozivao na posao, na rovinjskom "el dasparà" što znači "očajan". Taj zvuk je označavao da rad uskoro počinje i da moraju požuriti. (A.R.)

Kao pozitivni statusni simbol vrlo se često ističe zlatni nakit koji Rovinjke kupuju kod domaćih zlatara, ali i u Kopru (ibid.).

Veliki je uspjeh bio ako su si uspjele priuštiti "el curdòn cun la Cruz e i ricini cumpagnadi“, odnosno lančić koji se sastojao od nekoliko niti s privjeskom u obliku križa i s kompletom naušnica. Naravno, to je sve trebalo biti zlatno. Još je bolje bilo ako je nakit bio ukrašen skromnim dijamantnim listićima. Imam fotografiju svoje none tako uređene i sav taj nakit sam naslijedila. Zanimljivo je da su tabacchine Slavenke preferirale kao privjesak ljubičicu, emajliranu, onako više tradicionalno. (A. R.)

Razlika među radnicama ogledala se i u njihovom izgledu. 


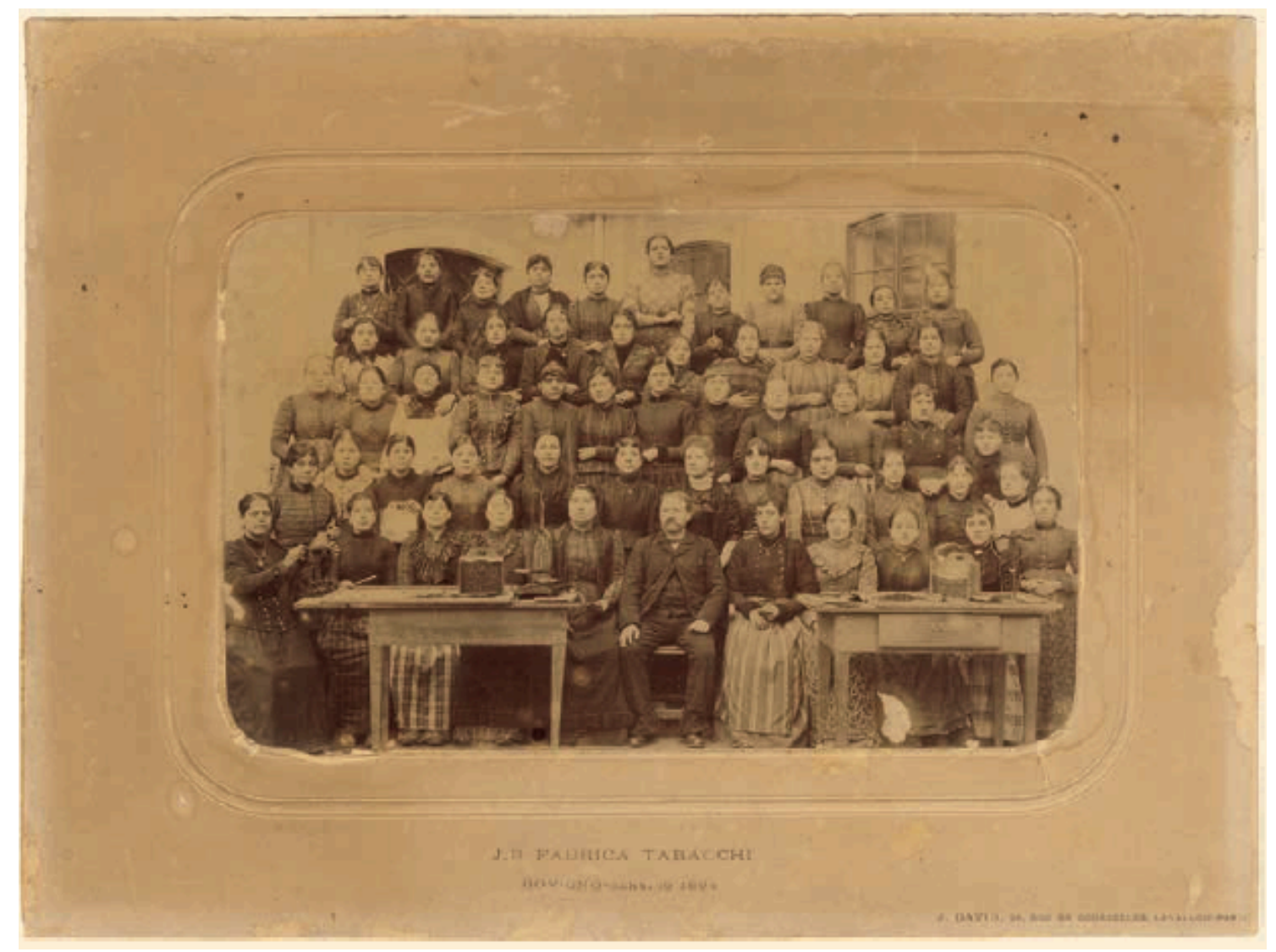

Slika 10. Radnice Tvornice duhana u Rovinju (tabakine) i poslovođa s napravama za rad i cigarama. Jean David, Rovinj-siječanj 1894. ZMGR/ MCCR 998:F (22/62). Muzej Grada Rovinja-Museo della città di Rovigno

Godine 1877. industrijalizacija Rovinja se nastavlja. Na sjevernoj strani grada, na samoj obali, osnovan je pogon za preradu i konzerviranje ribe toplinom - tehnikom "nantes". Tvornicu otvara francuska tvrtka Société Generale Francaise de Conserves alimentaires te nakon pet godina rada zapošljava 148 radnika od čega 120 žena. Postrojenje je dalo zamah i povrtlarstvu jer je, osim ribe, konzervirano i povrće. Unatoč pojedinim godinama slabog ulova te snažnoj konkurenciji istarske, kvarnerske, dalmatinske, pa i tršćanske prehrambene industrije, rovinjska je riblja industrija bilježila konstantan rast (Budicin 1997: 439). ${ }^{74}$

74 "Mirna d. d., tvornica za lov, preradbu i promet ribom i ribljim prerađevinama, osnovana 1877 . u Rovinju. Djelatnost je započela kao podružnica pariškog poduzeća Société générale française de conserves alimentaires. Promjenom vlasničke strukture 1906. vlasnikom joj je postalo poduzeće Ampelea sa sjedištem u Trstu, a od 1946. nosi današnji naziv. Od 1954. djeluje kao prehrambeni kombinat, a od 1993. kao dioničko društvo. Od 2014. većinski joj je vlasnik Podravka” (Hrvatski tehnički leksikon). 
Prema riječima kazivačice, rođene u Rovinju 1942. godine u imućnoj obitelji privatnih poduzetnika:

Još se od 17. stoljeća, iako ne u industrijskom smislu, razvija soljenje ribe kao ekonomska grana nad kojom je monopol držala Venecija. Međutim, Rovinjci su švercali soljenu ribu s Trstom i Rijekom, a 1882. otvara se prvi industrijski pogon. 1905. tu proizvodnju preuzima moja obitelj, moj nonno Luigi s bratom Giuseppe-om. Tada se pogon nalazio točno preko puta stare klaonice, malo naprijed od Tvornice duhana. 1930-ih tvornica postaje Societa' anonima fabbrica italiana conserve alimentari i mijenja naziv u Ampelea. Tada zapošljava oko 450 osoba, naravno, uz prevlast žena od 14 godina i starije, poznate kao sardelline. Tvornica je 1948. nacionalizirana i promijenila je naziv u Mirna.

Dok je moja obitelj upravljala tvornicom, u periodu najjačeg ulova zapošljavalo se i preko 500 osoba. Ali jasno, to je bio nestalan posao, možemo reći sezonski, koji je ovisno o sirovini i u velikoj mjeri o meteorološkim uvjetima. Zbog toga je taj posao bio manje poželjan od onog od tabacchine. (A. R.)

Karakteristike monopolističkog kapitalizma po kome je TDR u prvoj fazi funkcionirao ogledale su se u osiguranoj tjednoj minimalnoj plaći, desetosatnom dnevnom radnom vremenu, osiguranom tržištu i sigurnim sirovinama. "Od samog početka, pa sve do kraja Prvog svjetskog rata, rovinjska je tvornica bila dio k.k. Tabakregie, državnog monopola u kojem je bila koncentrirana cjelokupna prerada i trgovina duhanom na području carstva" (Džeba 1987: 51). Takvu sigurnost omogućavalo je tržište koje je 1885. godine vidjelo rekordnu prodaju cigara (Fellner i Thiel 2009: 42). Kao kontrapunkt Tvornici duhana, ne samo kao industrijski pogon već i industrijski pogon sa zamjetnom ženskom radnom snagom, od 1877. godine stoji Mirna d.d. (Ampelea). Od osnutka pa sve do Drugog svjetskog rata Mirna je u privatnim rukama; najprije pariške, a potom talijanske tvrtke (Ferenčić, istrapedia.hr). ${ }^{75} \mathrm{Za}$ razliku od monopolističkog kapitalizma, kompetitivni nema sigurnost tržišta, a u slučaju Mirne često ni primarne materije (ribe).

Industrijalizacija je dakako potakla i brojne promjene: "pomicanje ljudi sa sela u grad, urbanizaciju, propadanje sela, porast broja stanovnika u gradu, prestrukturiranje pučanstva" (Dukovski 2010: 160). Drugu stranu medalje prema Dukovskom predstavljaju ,...siromaštvo, zarazne bolesti, pljačke i ubojstva, a gospodarski razvoj zaustavlja I. svjetski rat i polukolonijalna politika talijanske uprave nakon 1918. godine“ (ibid.). Dukovski u svom radu opisuje prilike u većem djelu Istre, pa je u

\footnotetext{
${ }^{75} \mathrm{https}$ ://www.istrapedia.hr/hrv/298/mirna-dd-rovinj/istra-a-z/, pristup 5. 11. 2019.
} 
kontekstu specifičnog mikrolokaliteta kojim se u ovom radu bavimo, nužno navod uzeti sa rezervom. Same kazivačice ne spominju loše strane industrijalizacije, iako ih je nedvojbeno bilo, a spomenute nedaće nije moguće vezati isključivo uz procese industrijalizacije (primjerice siromaštvo i bolesti), već je nužno detaljnije razmotriti društveno-političke i ekonomske dinamike gotovo pa na godišnjoj razini, s obzirom da se $u$ tom periodu svakodnevica mijenja iz dana u dan. Prisjetimo li se deseterostrukog rasta u proizvodnji koje su radnice TDR-a ostvarile u godinu dana, a zatim i napredak tehnologije i politička previranja s eskalacijom u Prvom svjetskom ratu, biti će nam jasnije kako su promjene koje su se dešavale bile ne samo drastične nego i iznimno brze u odnosu na gotovo konstantnu četverostoljetnu vlast Venecije nad Rovinjom. Dapače, iako klasne razlike postoje od samih početaka, prva faza rovinjske industrijalizacije podrazumijeva spas od siromaštva s obzirom na propalu ekonomiju na moru; zatim bolje higijenske i nutricionističke uvjete jer obitelji stječu mogućnost samostalnog života $u$ većem prostoru od onog dijeljenog sa širom obitelji, omogućava se nešto kvalitetnija ishrana i medicinska pomoć dostupna u sklopu tvornice. Prema onome što je kazivačici (A. R.) prenosila majka, a što je ova pak čula od svoje majke, saznajemo nešto više detalja o klasnim razlikama na samom početku stoljeća, a u tom smislu i mjestu koje su zauzimale tabacchine.

Nonna s tatine strane, čije ime nosim, imala je dvanaestero djece od kojih je polovina preminula u najranijoj dobi, najčešće zbog difterije i španjolske gripe, a znalo se desiti i zbog krive dijagnoze, iako je djed bio toliko imućan da je mogao dovesti liječnike iz Trsta. Isto ne mogu reći za tabacchine; jer, iako su imale dobru zaradu, za vrijeme Austrije, kako je moja nonna govorila, s quinicinom [plaća ostvarena na temelju petnaestodnevnog rada] u austrijskim krunama, mogla je pokriti troškove najma stana i dobar dio troškova hrane, a za ostalo se trebalo snaći s onime što je nonno mogao privrediti kao ribar. Ovdje govorim o djelu obitelji koja predstavlja tadašnji proletarijat, ne o onima s očeve strane koji su predstavljali dobrostojeću buržoaziju. (A. R.)

Iako nas Dukovski upućuje da "na početku 20. stoljeća nije moguće još govoriti o gradskoj industrijskoj sirotinji kao zasebnom sloju, a još manje kao o socijalnoj skupini“ (Dukovski 2010: 160), iz navedenog je jasno da je rovinjsko društvo na prijelazu stoljeća snažno klasno stratificirano i da oni koji rade kao ribari, a čije žene ne nalaze posao u tvornici, zaista žive na rubu egzistencije. Takvo se stanje zadržava sve do iza 2. svjetskog rata. Osim najsiromašnijih obitelji ribara i poljoprivrednika nadničara, u "Pučanki mora" stanuju obrtnici, vlasnici vinograda i maslinika, trgovci te 
tvornički radnici/ce uz manji broj pripadnika srednje i više klase. Obiteljska sjećanja kazivačice čija šira obitelj obuhvaća gotovo sve navedene slojeve, konkretnim nam primjerima omogućava živu usporedbu životnih uvjeta dviju žena, radnica u istom gradu.

Srednja buržoazija je držala svoje kćeri kod kuće; uglavnom su ih učitelji podučavali kod kuće, učile su svirati klavir i družile su se među sobom kao što je bio slučaj sa sestrama mog oca, mojim tetkama. Simpatične tabacchine su s druge strane bile vitalan dio građanskog života. Važno je pri tom naglasiti da je još za vrijeme Austrije osnovno obrazovanje bilo omogućeno svima, tako da je postotak analfabeta bio zaista nizak, pa ne možemo reći da su tabacchine bile neuke. Dapače, mnoge su bile uključene i u razne kulturne aktivnosti. U mojim razgovorima s mamom i bakom, često se sugeriralo da je zahvaljujući školovanju i plaćenom radu razina samosvijesti žena značajno narasla, pa su se i odnosi unutar obitelji promijenili. (A.R.)

Osim za Rovinjke/ce, otvaranje brojnih tvornica utječe i na život mještana okolnih sela, posebno Rovinjskog Sela. Unatoč blizini grada, Rovinjsko Selo živi potpuno drugim ritmom. Početkom 20. stoljeća od 740 žitelja, 691 je Hrvat, uz 7 Slovenaca i 39 Talijana. Austrijska vlada cijelo 19. stoljeće, pa i kasnije, zanemaruje istarske Hrvate kulturno i prosvjetno što se u gradu „,poistovjećivalo s inferiornosti, ne samo u narodnosnom smislu, već i biološkom, odnosno mentalnom“ (ibid. 161). Ne čudi stoga nacionalna diskriminacija prilikom zapošljavanja o kojoj kazivačice svjedoče, a posebno za vrijeme Italije. Industrijalizacija pod Austrijom, ali i uopće, imala je i druge loše efekte na pojedince i društvo. Činjenica da rad izaziva oboljenja koja dotad nisu prisutna kod žena, svakako je jedna od njih. Na žalost, službene podatke $\mathrm{i}$ istraživanja za rovinjsku tvornicu još nemamo, ali ih možemo dovesti u relaciju $\mathrm{s}$ podacima generiranima na temelju arhivskih materijala senjske tvornice duhana $\mathrm{i}$ dostupnih kazivanja.

Jako je teško bilo raditi na selekciji lišća jer nakon što su vratili lišće sa sušenja, a to se radilo gore u barakama, lišće je trebalo imati određenu vlažnost. Te žene jadne, to je bio smrad, kada su izlazile iz sobe za selekciju bile su potpuno ošamućene od tog smrada, vlažnosti. (M. R.)

Bernardino Ramazzini (1964) piše o bolestima koje nastaju kao posljedica rada s duhanom, kojima ulazi u trag već od 1713. godine. Povezuje ih s loše ventiliranim prostorijama, vlažnošću i duhanskom prašinom. Žene su se žalile na glavobolju, kašalj, 
mučninu i povraćanje. Istraživanja Valića, Beritića i Butkovića (1976) također pokazuju i porast broja astmatičara, koji dodatno povezuju s lošim ventilacijskim sustavima $\mathrm{u}$ radničkim dvoranama. U istraživanju obavljenom 2008. godine Mustajbegović i suradnici su na uzorku od 121 radnika (97 žena i 24 muškarca) te 98 kontrolora (73 žena i 25 muškaraca) pokazali da je kod svih njih zabilježen visok postotak kroničnih respiratornih simptoma, a postotak je bio značajnije viši kod žena izloženih duhanskoj prašini negoli kod izloženih muškaraca ili kontrolora (muških i ženskih). Astma je zabilježena kod 6 žena, ali kod nijednog kontrolnog tijela. Od akutnih simptoma navode suhoću nosa i grla te iritaciju očiju (Mustajbegović et al. 2008). Slične podatke nam podastire Mira Kolar-Dimitrijević na primjeru senjske tvornice duhana u periodu od 1918.-1941. Konkretno, Kolar-Dimitrijević navodi da su "radni sustav i niske zarade podrovali zdravlje radnica $u$ tolikoj mjeri da je situacija u jesen 1931. postala alarmantna" te da "je duhanska prašina satirala pluća radnica i da je većina radnica obolijevala nakon dvogodišnjeg rada u tvornici” (Kolar-Dimitrijević 1979: 48). Od 480 radnica od akutne tuberkuloze oboljelo 68 radnica, a 70\% radništva je bilo tuberkulozno (ibid.: 42). Uz navedeno, autorica će dalje navesti premor i pothranjenost kao dodatne uzroke lošeg zdravstvenog stanja (ibid.: 48). Iako većina rovinjskih kazivačica ne spominje bolesti ili ih eventualno povezuje s konzumacijom duhana, a ne samim proizvodnim procesima, pažljivim iščitavanjem intervjua, vidjeti ćemo da uvjeti rada za zdravlje radnica nisu bili idealni, kao što je razvidno iz posljednjeg citata usko vezanog uz ošamućenost radnica. Također, na tragu onoga što Kolar-Dimitrijević navodi kao dodatne indirektne uzroke lošeg zdravstvenog stanja radnica, životni uvjeti pojedinih rovinjske radnica bili su toliko teški, da su ih premor i pothranjenost dodatno opterećivali.

Da, u to vrijeme '30-'40 godina je bilo dobro u fabriki, ali moja mama ni bila zadovoljna da ide u fabriku tabaki jer tamo nisi imao šta jesti, znaš. Ako si ponesa od doma si ima, ako nisi ponesa, nisi ima. Moja mama je puno, puno puta pola ure bila u wc-u bez jest, bez niš. U Mirni je mogla pojest malo ribe, joj je bilo puno, puno bolje. (D.C) 


\section{2. Primijenjeni intersekcionalizam}

Od kasnih 1980-ih intersekcionalizmom se prvenstveno nastoji pokazati podređena pozicija crnkinja. Tomu je tako jer se razvija iz pravne prakse koja je za klijentice imala upravo crnkinje. $U$ analizi i pripremi obrane, odvjetnica Kimberle Crenshaw uočila je da su crne žene dvostruko diskriminirane: u odnosu na rod i rasu. Feministkinje su nastavile razvijati teoriju i uočile njezinu raznovrsnu, ali i univerzalnu primjenu. Tako je danas ona primjenjiva i na "razotkrivanje maskuliniteta", kako će Sirma Bilge (2009) reći u radu "Smuggling Intersectionality into the Study of Masculinity". Iako ne postoji jasno definirana intersekcijska metodologija, već ona ovisi o intuiciji, specifičnom znanju istraživača te kontekstu analizirane situacije, Bilge (2009: 7) ipak nudi svojevrsni instrument koji može biti od pomoći u primjeni intersekcijske analize. Bilge intervjuima i izvorima najprije pristupa induktivnom metodom, pri čemu kroz otvoreno kodiranje otkriva koncepte i teme, povezujući ih potom fokusiranim kodiranjem. ${ }^{76}$ Druga faza podrazumijeva teorijski orijentiranu dedukciju tih koncepata i reinterpretaciju kroz posebno dizajniran obrazac (vidi dalje) (ibid.: 5-6).

Opća intersekcijska tablica predlaže nekoliko kategorija koje bi istraživači morali na fleksibilan i situirano-specifičan način uzeti u obzir prilikom istraživanja društveno generiranih razlika temeljenih na intersekciji identiteta poput klase, rase, roda i dr., a sve kako bi eventualno uočili način na koji intersekcija tih identiteta stvara hegemonijske odnose. Analizom dostupnih povijesnih i etnografskih (terenski prikupljenih) podataka, u ovom radu promatramo društvene kategorije roda, $\mathrm{klase}^{77} \mathrm{i}$

\footnotetext{
${ }^{76}$ Otvoreno kodiranje podrazumijeva da se terenskim bilješkama i intervjuima vraćamo tako da ih čitamo rečenicu po rečenicu (usporeno čitanje) i pokušavamo identificirati, odnosno oblikovati "ideje, teme ili pitanja koje nam sugeriraju" terenske zabilješke. Fokusirano kodiranje, s druge strane, označava tematsko (pre)grupiranje građe ili klasificiranje koje pokušavamo tematski povezati, odnosno kategorizirati (Potkonjak 2014: 83).

77 "Društvene klase, skupine s istim ili sličnim materijalnim i kulturnim položajem u društvu, koje obilježava svijest o zajedničkoj (klasnoj) pripadnosti. U užem smislu, društvene klase pojavljuju se $s$ industrijskim društvom pa su otvorenije i dinamičnije od kasta i staleža u predindustrijskim društvima. Za razliku od društvenih slojeva (strata), pripadnici klase skloniji su boriti se za svoje interese (npr. radnici i poslodavci). No neke teorije društva izjednačavaju klase sa slojevima ili ih smatraju vrstom slojeva. Osnivač klasne teorije društva K. Marx smatrao je da se radnici mogu ponašati kao klasa svjesna svojega položaja i svojih mogućnosti ('klasa za sebe') i kao sloj, tj. skupina po zanimanju koja samo obavlja određeni rad za nadnicu ('klasa po sebi'). Analizirajući kapitalizam svojega doba, Marx razlikuje tri
} 
nacionalnosti kao temeljne razlikovne kategorije, uključujući, gdje je moguće i nužno, dodatne kategorije koje nas informiraju o specifičnosti situacije, a to su u našem slučaju životna dob i jezik. Kategorije dobi i jezika ću, vođena teorijskim postavkama Beverly Skeggs, tretirati zajedno s mirisima, odnosno smradom unutar kategorije "tjelesnosti”.

osnovne klase: radnike, kapitaliste i zemljoposjednike. Osnovu takve klasifikacije čine tri izvora prihoda: nadnica, profit i renta. Kada, međutim, analizira njihove interese s obzirom na način proizvodnje i njezinu svrhu, govori samo o radnicima i kapitalistima kao o dvjema međusobno suprotstavljenim klasama. Dihotomna podjela klasa počiva na vlasničkim i nevlasničkim interesima: rentijerstvo i profiterstvo međusobno su spojivi, a suprotstavljeni interesima radnika koji se nalaze u najamnom radnom odnosu prema vlasnicima. Uz to radnicima Marx pridaje revolucionarno značenje kao klasi koja će društvo osloboditi najamnoga rada, nepravedne raspodjele i društvene nejednakosti. Suprotstavljajući se Marxovu poimanju, M. Weber polazi od 'situacije klase', tj. od vjerojatnosti ili šanse da pojedinci imaju ili očituju iste interese. Te se šanse stvaraju na tržištu a ne u proizvodnji. Zato Weber klasu smatra čisto ekonomskom kategorijom i sklonom unutarnjem fragmentiranju, odn. slojevitosti, pa je cijela podjela društva mnogo stupnjevitija, a težnje prema središnjemu klasnom sukobu najčešće se raspršuju u mnogo manjih sukoba. Također, prema Weberu, klasna pripadnost ne određuje nužno društveni ugled (staleški status, profesije), kao ni političku moć ljudi (političke stranke). Zbog toga je ukupna društvena slojevitost ili stratifikacija vrlo složena struktura privilegiranih i neprivilegiranih položaja. Netko može zauzimati visok položaj na jednoj hijerarhiji a niži na drugoj: npr. skorojević s mnogo novca ne mora biti javno ugledan član društva i obrnuto" (http://www.enciklopedija.hr/natuknica.aspx?ID=16318, pristup 1. 11. 2019.). 
Tablica 1. Opći intersekcijski obrazac, Sirma Bilge (2009)

\section{A Generic Intersectionality Template}

\begin{tabular}{|c|c|c|}
\hline $\begin{array}{l}\text { Social } \\
\text { Categories }\end{array}$ & $\begin{array}{l}\text { Discrete } \\
\left(1^{\text {st }} \text { step }\right)\end{array}$ & $\begin{array}{l}\text { Intersectional consideration } \\
\left(2^{\text {nd }} \text { step }\right)\end{array}$ \\
\hline Gender & $\begin{array}{l}\text { How gender informs this } \\
\text { individual account? }\end{array}$ & $\begin{array}{l}\text { How gender interacts/intersects with other } \\
\text { social categories in this individual account? } \\
\text { Or which dimensions of the experience are } \\
\text { interacting with gender? }\end{array}$ \\
\hline Class & $\begin{array}{l}\text { How class informs this } \\
\text { individual account? }\end{array}$ & $\begin{array}{l}\text { How class interacts with other social } \\
\text { categories in this individual account? } \\
\text { Or which dimensions of the experience are } \\
\text { interacting with class? }\end{array}$ \\
\hline Race & $\begin{array}{l}\text { How race informs this } \\
\text { individual account? }\end{array}$ & $\begin{array}{l}\text { How race interacts with other social } \\
\text { categories in this individual account? } \\
\text { Or which dimensions of the experience are } \\
\text { interacting with race? }\end{array}$ \\
\hline Ethnicity & $\begin{array}{l}\text { How ethnicity informs } \\
\text { this individual account? }\end{array}$ & $\begin{array}{l}\text { How ethnicity interacts with other social } \\
\text { categories in this individual account? }\end{array}$ \\
\hline Religion & $\begin{array}{l}\text { How religion informs } \\
\text { this individual account? }\end{array}$ & $\begin{array}{l}\text { How religion interacts with other social } \\
\text { categories in this individual account? }\end{array}$ \\
\hline $\begin{array}{l}\text { Sexual } \\
\text { Orientation }\end{array}$ & $\begin{array}{l}\text { How sexual orientation } \\
\text { informs this individual } \\
\text { account? }\end{array}$ & $\begin{array}{l}\text { How sexual orientation interacts with other } \\
\text { social categories in this individual account? }\end{array}$ \\
\hline Age & $\begin{array}{l}\text { How age informs this } \\
\text { individual account? }\end{array}$ & $\begin{array}{l}\text { How age intersects with other social } \\
\text { categories in this individual account? }\end{array}$ \\
\hline Handicap & $\begin{array}{l}\text { How handicap/ } \\
\text { ablebodiness informs this } \\
\text { individual account? }\end{array}$ & $\begin{array}{l}\text { How handicap/ablebodiness intersects with } \\
\text { other social categories in this individual } \\
\text { account? }\end{array}$ \\
\hline $\begin{array}{l}\text { Other relevant } \\
\text { categories } \\
\text { (immigration } \\
\text { status, family } \\
\text { status, } \\
\text { language, etc) }\end{array}$ & $\begin{array}{l}\text { Are there other relevant } \\
\text { social categories/ } \\
\text { relations informing this } \\
\text { individual account? }\end{array}$ & $\begin{array}{l}\text { How other relevant categories interact with } \\
\text { previous social categories in this individual } \\
\text { account? }\end{array}$ \\
\hline
\end{tabular}


Tablica 2. Situirano-specifičan obrazac, Tamara Nikolić Đerić (2019)

\begin{tabular}{|c|c|c|}
\hline $\begin{array}{l}\text { Društvena } \\
\text { kategorija }\end{array}$ & Određeno razmatranje & Intersekcijsko razmatranje \\
\hline Rod & $\begin{array}{l}\mathrm{Na} \text { koji način rod određuje } \\
\text { položaj radnice? }\end{array}$ & $\begin{array}{l}\text { Kako je rod povezan s drugim } \\
\text { društvenim kategorijama? I, koje } \\
\text { su dimenzije iskustva u } \\
\text { interakciji s rodom? }\end{array}$ \\
\hline Klasa & $\begin{array}{l}\text { Na koji način klasa određuje } \\
\text { položaj radnice? }\end{array}$ & $\begin{array}{l}\text { Kako je klasa povezana s drugim } \\
\text { društvenim kategorijama? I, koje } \\
\text { su dimenzije iskustva u } \\
\text { interakciji s klasom? }\end{array}$ \\
\hline Nacionalnost & $\begin{array}{l}\mathrm{Na} \text { koji način nacionalnost } \\
\text { određuje položaj radnice? }\end{array}$ & $\begin{array}{l}\text { Kako je nacionalnost povezana s } \\
\text { drugim društvenim } \\
\text { kategorijama? I, koje su } \\
\text { dimenzije iskustva u interakciji s } \\
\text { klasom? }\end{array}$ \\
\hline Tjelesnost & $\begin{array}{l}\mathrm{Na} \text { koji način tjelesnost } \\
\text { određuje položaj radnice? }\end{array}$ & $\begin{array}{l}\text { Kako je tjelesnost povezana } \mathrm{s} \\
\text { drugim } \\
\text { kategorijama? I, koje su } \\
\text { dimenzije iskustva u interakciji s } \\
\text { tjelesnosti? }\end{array}$ \\
\hline
\end{tabular}

Ovakav situirano-specifičan obrazac upućuje nas na identitete koji su zastupljeni na rovinjskom primjeru i koji u međuodnosu uvjetuju nejednakost. Svako od ovih pitanja sagledat ću kroz dvije tematske podcjeline: "rad" i "ne-rad”, odnosno plaćeni industrijski rad i rad u sklopu domaćinstva (prema Federici 1975: 2) te kroz četiri društveno-politička sustava, odnosno tri različite organizacijske kulture i načina upravljanja (Austro-Ugarska 1872.-1918., Kraljevina Italija 1918.-1943., Federativna 
Narodna Republika Jugoslavija 1947.-1963. i Socijalistička Federativna Republika Jugoslavija 1963.-1972.) ${ }^{78}$ kako bih dokazala tezu o ekonomskoj stabilnosti kao preduvjetu ženske emancipacije. Kako nijedan novčić nije jednostran, analizom ću nastojati ukazati da subordinirana pozicija žena i nakon djelomične emancipacije nije nestala, ona je samo promijenila svoju "lokaciju".

\section{3. Pisani izvori: Knjiga radnica TDR-a}

Prva Knjiga radnica i danas se čuva u nekadašnjoj zgradi u kojoj su tabacchine obrađivale duhan. Zahvaljujući susretljivosti Odjela za odnose s javnošću Adris grupe, ${ }^{79}$ tvrtke koja je nastala spajanjem TDR-a i Jadran d.d.-a, a koja je u 21. stoljeću nastavila drugačiji razvoj orijentiran prije svega investicijama u turizmu, marikulturi, osiguranju i dr., imala sam priliku pregledati Knjigu radnica i fotografirati one dijelove koje sam tada smatrala relevantnima za ovaj rad. S djelatnicima sam i nakon tog prvog čitanja nastavila komunikaciju te sam, zahvaljujući tome, u narednim fazama istraživanja i dalje uspijevala provjeravati određene podatke i dopunjavati informacije, a prema novim potrebama.

Knjiga radnica se vodi od prvog dana osnutka Tvornice kada su pogoni bili u Ulici San Damiano, u starogradskoj jezgri Rovinja. Prema navodima državnog odvjetnika Merkla von Reinseea, za rad se predbilježilo 700 djevojaka, od kojih je u tom prvom periodu zaposleno njih 391, uz trojicu nadzornika $\mathrm{i}$ rukovodioca te sedmoricu radnika (Džeba 1987: 60). Po uzusu austrijske birokracije, Knjiga radnica sadrži vrlo detaljne podatke za svaku radnicu ponaosob. Tako će se pomnim povijesnim istraživačima razotkriti:

- ime i prezime radnice, dob i prebivalište,

- mjesto, datum i godina rođenja,

- država podrijetla (najčešće se upisivao grad),

- bračni status s mogućnošću izbora između slobodna, udana, udovica,

\footnotetext{
${ }_{78}^{78}$ Godine se odnose na radom obuhvaćen period.

79 Posebno se zahvaljujem gospođi Kristini Miljavac na dugogodišnjoj podršci i susretljivosti po pitanju pristupa knjizi radnica.
} 
- općina koja je izdala dokument na temelju kojeg se vrši zaposlenje,

- prijašnji poslodavac,

- vrsta prihvatnog dokumenta,

- odjel na koji se radnica raspoređuje i datum,

- informacije o povišici ili unapređenju,

- informacije o razlogu prekida poslovnog odnosa s mogućnošću izbora između: slobodno napuštanje, nesposobnost za rad, smrt, otkaz po kazni određenoj od strane nadzornika,

- tip invalidnine.

Ono što je od interesa za ovaj rad, a što je moguće iščitati iz knjiga, odnos je muškaraca i žena, odnos djevojaka talijanskog i hrvatskog podrijetla, odnos djevojčica i žena. Analiza odnosa među radnicama uvjetovanog klasom izostavljena je zbog toga što je riječ o ranom periodu razvoja radničke klase i zato što nemamo podataka o drugom tvorničkom pogonu. Prvo Društvo radnika i radnica Rovinja osniva se 1872. godine i broji 312 članova, a prva organizirana grupa socijalista javlja se već 1898 sa sjedištem u čitaonici u Ulici Dietro Castello (ibid.: 44). Pri analizi je manje pažnje posvećeno statistici, odnosno brojčanim odnosima, posebno zato što su to podaci koje nalazimo u drugim povijesnim pregledima razvoja tvornice (Benussi 1888; Budicin 1997; Džeba 1987). Stoga, cilj nije bio analizirati svaki upis i usporediti sve navedene kriterije, već kritičkim čitanjem podataka podastrijeti nove poglede na poziciju rovinjskih radnica. Važno je naglasiti kako je Džeba u navedenom, iznimnom, izdanju o povijesti Tvornice duhana Rovinj, a povodom 115 godišnjice njezina osnutka, svjestan svih poteškoća koje su zadesile rovinjske radnice, međutim tim poteškoćama nije posvećeno dovoljno pažnje s obzirom na format knjige. Ono što je simptomatično jest da u dostupnim tumačenjima tvorničke povijesti i razvoja gotovo da nema ženskog glasa, a u rijetkim trenucima kada ga ipak čujemo doima se stopljenim u generalnu kakofoniju uspjeha, rasta i prestiža.

Mi ćemo se, slijedom intersekcijske metodologije, fokusirati na nekoliko primjera s ciljem izbjegavanja poopćavanja i statistifikacije. Također, izbjeći ćemo to da naša analiza započne s prvom radnicom, s obzirom na to da je ona već mitska figura 
čijim imenom počinju (i završavaju) sve priče o rovinjskim radnicama. $97 \%$ radne snage prvog pogona činile su žene. Prvi zaposleni muškarac, pod rednim brojem 3., je udovac Giuseppe Bartoli zaposlen kao varilac. Odmah iza njega, na radno mjesto motačice duhana zaposlena je Antonia Flego, dvadesetogodišnja Rovinjka. Antonia je u petnaest navrata nagrađivana različitim svotama u iznosu od 13 do 15 austrijskih kruna $i$ to $\mathrm{u}$ periodu od 1905. do 1910. godine. S obzirom na to da se slična periodizacija nagrađivanja uočava i kod drugih radnica, čini se kako je to bio najprosperitetniji period tvornice. Antonia odlazi u invalidsku mirovinu 1910. godine, nakon 38 godina radnog staža s mirovinom u iznosu od 56 kruna mjesečno. Pod rednim brojem 21 u tvorničku Knjigu radnica upisana je Rovinjka Maria Brajaka, koja je udana za osobu stranog, moguće morlačkog podrijetla. Maria ima trinaest godina i zaposlena je na najnižoj poziciji koja podrazumijeva razvrstavanje duhana. Prema podacima koje nam je Budicin predstavio (1997), moguće je da je njezina početna plaća iznosila oko 6-7 kruna tjedno, ne samo zato što je radila na najnižoj poziciji nego i zato što je, najvjerojatnije, zaposlena kao vježbenica. Maria je već nakon dvije godine premještena na višu poziciju, onu motačice cigareta. Otad je višekratno nagrađivana manjim iznosima, da bi joj 1905. godine (nakon 33 godine radnog staža) bila odobrena plaća u iznosu od 13 austrijskih kruna tjedno.

Analizom matične knjige vjenčanih pokazali smo da su se u TDR-u zapošljavale uglavnom Rovinjke, s izuzetkom dviju djevojaka iz Savičente i Labina, koje su, pretpostavljamo, slavenskog podrijetla. Budući da je upis u knjizi vjenčanih iz 1906. godine, dakle 34 godine od osnutka Tvornice, a da Knjiga radnica ne bilježi nijednu zaposlenu djevojku slavenskog/hrvatskog podrijetla, mogli bismo zaključiti da u najranijem periodu nije bilo potrebe za vanjskom radnom snagom te da je to jedan od razloga zbog kojeg se stranci/strankinje, odnosno konkretno Slavenke/Hrvatice ne zapošljavaju. Međutim, pažljivom analizom Knjige radnica, uočit ćemo da se strankinje ipak zapošljavaju. Godine 1873. u radni odnos ulazi Maria Bino iz Trsta, a 1875. MariaAntonia Doria, desetogodišnja djevojčica iz Chioggie, (Knjiga radnica, redni broj 78.), obje, dakle, talijanskog podrijetla. Važno je pritom naglasiti da su djevojke neudane u trenutku zaposlenja, što će reći da nisu zbog udaje došle u Rovinj pa se potom zaposlile, već je vjerojatnije da su u Rovinj došle poslom ili slijedeći obitelj. 


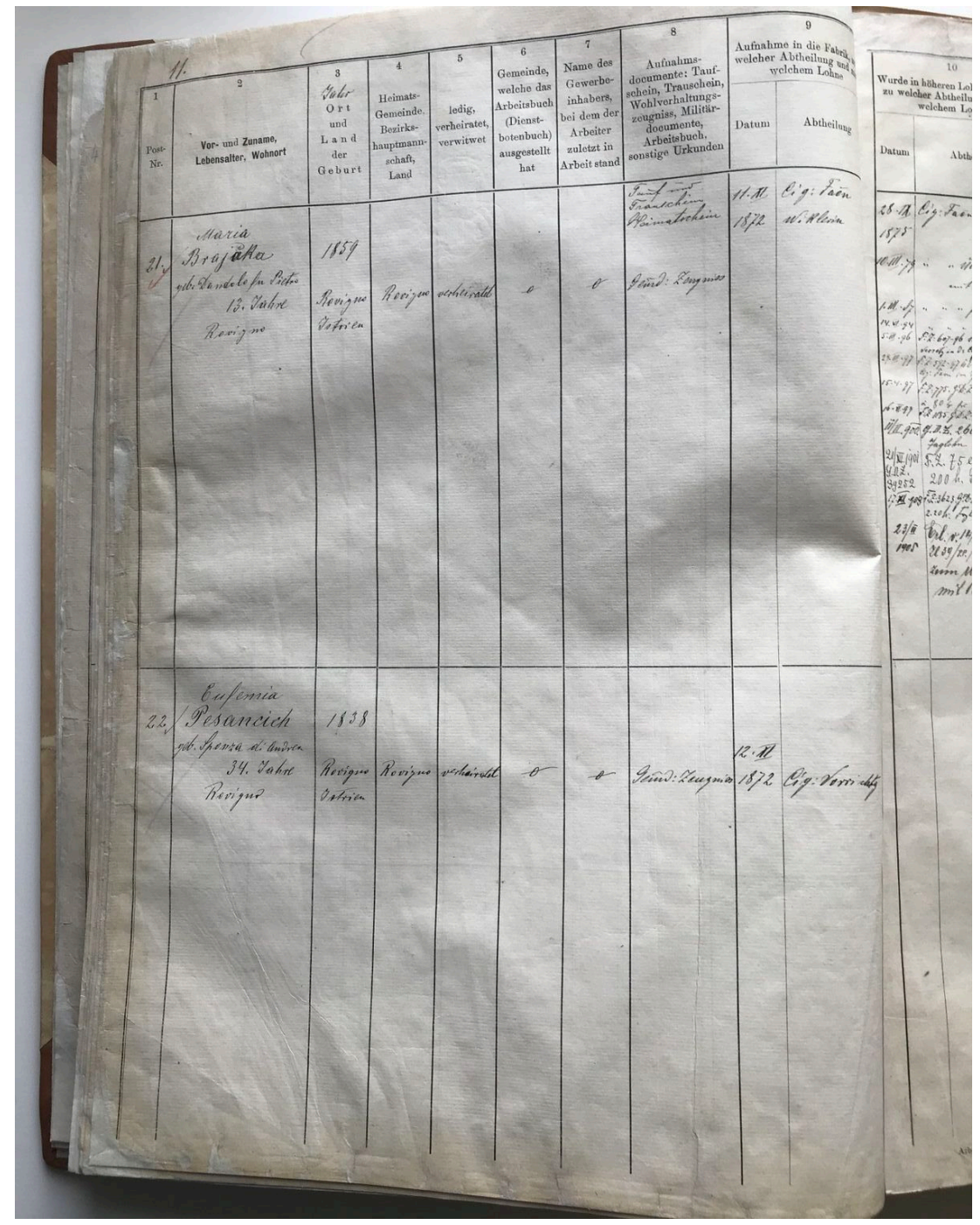

Slika 11. Izvod iz Knjige radnica Tvornice duhana Rovinj - Maria Brajaka Fotografija: Kristina Miljavac

\section{4 . O teoriji sjećanja}

“Tradicionalno shvatanje odnosa između istorije i pamćenja je relativno jednostavno. Istorija treba da bude 'podsetnik', čuvar sećanja na javne događaje koji se zapisuju da bi se proslavili njihovi akteri, a i zarad potomstva, koje treba da uči na njihovom primeru. Sećanje na prošlost i pisanje o njoj ne izgledaju više tako nevine 
radnje kao što se nekada ${ }^{80}$ smatralo" (Burke 1999: 83). Rovinjske radnice, kao dio radničke klase, nalaze se u liminalnom području između (industrijske) povijesti i društvenog pamćenja. Činjenica da dio ženske radničke klase postaje dio korpusa povijesnog znanja 19. stoljeća svrstava ih u kategoriju "podsjetnika na javne događaje koji se zapisuju da bi se proslavili njihovi akteri", međutim, to je jedan mali dio iskustava zapisan u samom trenutku stvaranja, a koji je bio iznimno selektivan.

U ovom ću se odjeljku baviti sjećanjima. Nakon pregleda povijesnih izvora i informacija o rovinjskim radnicama, nužno je napraviti distinkciju sjećanja kao individualnog ${ }^{81}$ fenomena koji predstavlja prvi dio empirijskog istraživanja i sjećanja kao kolektivnog fenomena, odnosno kolektivnog pamćenja u odnosu na službenu povijest. Iako govorim o tri kategorije koje ćemo pokušati jasno razlučiti - o povijesti, društvenom pamćenju i individualnom sjećanju - one su međusobno usko povezane, posebice s obzirom na to da se sjećanje kao individualni, subjektivni fenomen javlja kao refleksija društvenog konteksta u kojem pojedinac živi (usp. Vukušić 2013; Halbwachs 2013). Radi jasnijeg razgraničenja, koncept individualnog sjećanja neću označavati pojmom individualno pamćenje (u odnosu na ono kolektivno) kako to čine neki teoretičari kulture sjećanja, ${ }^{82}$ već ću za individualna, pojedinačna iskustva upotrebljavati izraz sjećanje iako se i on u literaturi koristi naizmjenično, ovisno o lingvističkoj tradiciji, a u značenju riječi memory. ${ }^{83}$ I Aleida Assman se osvrće na spor oko pojmova te nudi rješenje u razumijevanju pamćenja kroz tri različite razine ustrojstva ljudskog pamćenja: neuronsko (utemeljeno na biološkoj ravni), socijalno (utemeljeno u socijalnoj interakciji) i kulturalno (interakcija uz pomoć znakova) (usp. Assman 2011: 33-38).

\footnotetext{
80 "Herodot je smatrao da istorija treba da sačuva sećanja na velika dela Helena i varvara. To je memorijska osnova istorije - no ona, takođe, ima i objašnjavalačku funkciju, nastojeći da pokaže zašto je do određenog događaja došlo, a što istoriju razlikuje od hronike ili memoarskih zapisa. (...) Razdvajanje istorije i sećanja moralo je da sačeka pojavu prosvetiteljstva i razvoj kritičke istorije, pre svega u 18. i 19. veku"

${ }^{81}$ Korisno je navesti skepsu Susanne Sontag o postojanju nečega takvog kao što je kolektivno sjećanje. Sontag smatra da su sva sjećanja individualna te se ne mogu ponovno stvoriti. Ono što se naziva kolektivnim sjećanjem, prema njezinu mišljenju, nije sjećanje već stipuliranje (Assman 2015: 83).

${ }^{82}$ Aleida Assman 2011; Jan Assman 2007; Maurice Halbwachs 2013.

${ }^{83}$ Pamćenje, sposobnost zadržavanja i korištenja informacija. Pamćenje uključuje tri faze: kodiranje, pohranjivanje i pronalaženje. Kodiranje je pretvaranje ulaznih senzornih informacija u neki oblik reprezentacije koji je moguće pohraniti u pamćenju (vidni, slušni i semantički kodovi), tj. informacije se pohranjuju kao reprezentacije slika, zvukova ili značenje sadržaja informacije. Pohranjivanje je zadržavanje informacija tijekom određenoga vremena. Pronalaženje se odnosi na dosjećanje pohranjenih informacija (enciklopedija.hr). Sjećanje se u ovom radu tretira kao proces kodiranja i pohranjivanja, dok pamćenje sadrži i treću fazu, fazu pronalaženja.
} 
Individualno se sjećanje dugo smatralo najnepouzdanijim i najprolaznijim od

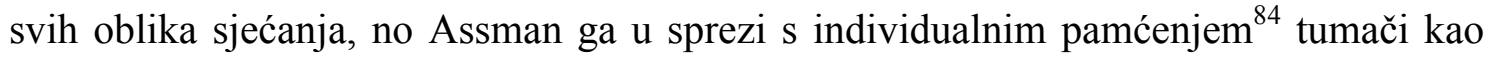
instrument nužan za građenje sebstva i vlastitog identiteta. Jedna od ključnih karakteristika individualnog sjećanja je ta da se, unatoč djelomičnim preklapanjima s tuđim sjećanjima, ono od njih ipak neminovno razlikuje (Assman 2011: 23). Također, "samo mali deo naših sećanja jezički je obrađen i obrazuje kičmu implicitne životne povesti. Najveći deo naših sećanja, da to izrazimo Prustovim jezikom, 'drema' u nama i čeka neki spoljašnji povod da bude "probuđen"” (ibid.) Početkom 20. stoljeća Maurice Halbwachs (1925) je ustanovio da je individualno pamćenje uvijek socijalno poduprto, a Assman će dodati da osobna sjećanja ne postoje samo u posebnom socijalnom miljeu već i u specifičnoj vremenskoj odrednici (ibid.: 24-25). U tom se kontekstu dešava reaktualizacija koja je ključna da bi se pamćenje, posebno ono kolektivno, ostvarilo. Individualno sjećanje je zavisno od socijalnog iz barem tri razloga. "Prvo, u njemu se koriste pojmovi koji su, kao i sam jezik, formirani u jezičkoj zajednici. Drugo, mnogih stvari se sećamo posredno, preko iskaza ili izveštaja drugih ljudi. Treći razlog socijalne uslovljenosti ličnog sećanja, koji Albvaš najviše tematizuje, jeste činjenica da pripadnost grupi utiče kako na sadržaj individualnog sećanja, tako i na njegovo pojavljivanje" (Sládeček, Vasiljević i Petrović-Trifunović 2015: 11).

No, zašto nam pored pisane povijesti treba sjećanje? U predgovoru zbornika Kolektivno sećanje i politike pamćenja urednici će reći da većina današnjih teoretičara ne smatra sjećanje protivnikom povijesti; povijesna analiza i traganje za uzrocima i povezanostima među prošlim događajima upotpunjuju se svjedočanstvima i iskustvima svjedoka događaja (u kontekstu istraživanja bliže prošlosti), dodajući tezu Aleide Assman (2011) da sjećanje nerijetko oblikuje interese i potiče aktivnosti povjesničara (Sládeček, Vasiljević i Petrović-Trifunović 2015: 17-18). Prema navedenim autorima, dva su razloga memory booma u posljednjim desetljećima 20. stoljeća, a koji je perzistentan i danas. Najprije je to priznanje da je povijest nedovoljna, odnosno da je nužan i interes za subjektivnim viđenjima aktera određenih događaja i njihovom osobnom valorizacijom tih događaja, a drugi se razlog ogleda u ekspanziji politika identiteta. U tom smislu, "nasuprot istoriji kao (više ili manje) linearnoj, koherentnoj i

\footnotetext{
84 Pamćenje predstavlja povezanost sjećanja. Nastavno, individualno pamćenje je dinamički medij
} subjektivne obrade iskustva (usp. Aleida Assman 2011: 24). 
homogenoj naraciji, pojavljuju se disonantne memorije - pre svega socijalno 'isključenih' ili marginalizovanih grupa, s njihovim alternativnim sjećanjima koje se ne poklapaju s većinskim ili službenopolitičkim. Pritom je njihovo traženje ravnopravnog statusa sećanja nezaobilazni deo politike identiteta, deo zahteva za njihov jednak pravni, politički, socijalni i kulturalni položaj" (ibid.: 18-20).

\section{5. Sjećanja nasuprot življenim iskustvima: koje je pravo lice radnice?}

Sjećanja na najranije dane industrijskog razvoja Rovinja, kao i povijesni izvori koje smo dosad predstavili tiču se, u većini slučajeva, radnica Tvornice duhana Rovinj. O sardellinama (radnice u Tvornici za preradu ribe) dosad gotovo da nismo saznali ništa. Znamo iz povijesnih izvora da je Tvornica za preradu ribe otvorena 1877. godine i da su od 140 zaposlenih njih 120 bile žene. Neposredno saznajemo da je to bio težak i nesiguran posao. Možemo se pitati zbog čega su informacije (u vidu pisanih izvora i sjećanja pojedinaca) o najranijim radničkim iskustvima sardellina nedostupne. $\mathrm{O}$ mehanizmima kulturnog pamćenja biti će riječi u narednom poglavlju. Sada ćemo se posvetiti življenim iskustvima i individualnim sjećanjima.

U razgovorima s kazivačima i kazivačicama radnicama duhanske i riblje industrije u mogućnosti smo obuhvatiti period u kojem direktno djeluju, dakle period $\mathrm{u}$ kojem rade u tvorničkim pogonima i to od 1948. godine sve do kasnih 1970-ih. Osim sjećanja na vlastita iskustva, kazivači i kazivačice nam prenose sjećanja na majke i bake kojima zahvaćamo period industrijskog razvoja od 1895. dalje. Rovinjke talijanskog podrijetla, radnice TDRa, posebno će se fokusirati na međugeneracijske odnose unutar obitelji i sjećanja na majke i bake koje su radile u TDRu. Svoj će posao u Tvornici tijekom 1960-ih godina smatrati uobičajenim. Radnice došljakinje ili potomkinje došljakinja će uglavnom govoriti o svojim iskustvima. Razlog takve podijele leži najvjerojatnije $\mathrm{u}$ generacijskom prijenosu rada koji se dešavao uglavnom unutar Rovinjskih obitelji i to u kontekstu TDRa, kako ću objasniti u narednim retcima. S obzirom da se rad u duhanskoj industriji smatrao prestižnim, ugled obitelji je rastao ukoliko su kćeri naslijeđivale majku i/ ili baku u industrijskom radu. Samo su dva primjera radnica čije su majke došle u Rovinj za vrijeme Italije, pa bilježimo dvije 
generacija radnica došljakinja. Obje su [majke kazivačica] s radom započele u Mirni i tek su se kasnije mogle zaposliti u TDRu.

\section{5. 1. Rad}

Ono čega se ja sjećam da su govorile je da su za vrijeme Austrije svi bili sretni, dobro su radili, dobro su zarađivali i sve je nekako bilo pošteno. S Italijom je već opala ta faza, već su bili oni koji su bili malo jači pa su stavljali svoje ljude na bolje pozicije i kao što za vrijeme Jugoslavije ako nisi bio komunist, tako za vrijeme Italije ako nisi bio fašist, nisi mogao imati poziciju šefa. Tako da, faze su bile različite, ali za vrijeme Austrije kao da je bilo puno, puno bolje. (M. R.)

U narednim ću redcima pokušati sagledati na koji se način pojedini Rovinjci i Rovinjke sjećaju svojih majki i baka, neki čak i prabaka u kontekstu javno plaćenog rada, a što ćemo kontrapunktirati življenim iskustvima s obzirom da su kazivačice $\mathrm{u}$ velikom broju bile zaposlene u tvorničkim pogonima od interesa. Iz uvodnog citata možemo primijetiti da je u naraciji prisutna romantizacija najdavnijeg perioda s kojim kazivačice nemaju direktan kontakt. Reprodukcija sjećanja na jugoslavensku i talijansku upravu, a u rijetkim prilikama i austrijsku je, prema navedenoj Assmanovoj kategorizaciji, međugeneracijska, dakle aktualna je u sadašnjosti i može se tumačiti društvenim sjećanjem. ${ }^{85}$

Kazivačica koja nas informira o općoj slici uvjeta rada kroz tri društvenopolitička sustava, a koju smo najavili kao povijesni okvir, dodat će:

Iz moje obitelji su radile pranona, nona, mama, tetka, svekrva i još jedna teta. I ja sam radila u tvornici od 1962. (M. R.).

\footnotetext{
${ }^{85}$ U katalogu fotografske izložbe o tabacchinama, autorica Tajana Ujčić navodi kako "ne treba zaboraviti da rovinjske tabakine nisu tek dio memorije grada, one još uvijek, ne samo u pjesmi, šeću Carerom i ulicama drugih gradova. Na fotografiji kat.br. 13 u zadnjem redu od vrha prema dolje četvrta je Elisabeta Sponza (Giuricin); u drugom treća je Giuricin, četvrta Francesca Sponza (Giuricin)...Na poleđini pojedinih fotografija nalaze se podaci o osobama od kojih su prikupljene fotografije..." (Ujčić 2014: 5). Osim direktnih iskustava i sjećanja na majke i bake koje u ovom radu predstavljamo, činjenica da je TDR i dalje jedan od najperspektivnijih hrvatskih poslodavaca koji pruža zaposlenje velikom broju stanovnika grada, danas u većoj mjeri muškarcima, zasigurno je uvjetovalo pozitivno javno mnijenje, kontinuiranu aktualizaciju sjećanja i glorifikaciju najranijih radnica. Nadalje, nabrajanjem imena $\mathrm{s}$ fotografija starih oko stotinu godina s poveznicom na njihove potomke, autorica jasno naznačuje aktualnost tih fotografija danas.
} 
$\mathrm{Na}$ temelju kazivanja o sjećanjima generiranim unutar obitelji kroz četiri generacije radnica Tvornice duhana Rovinja možemo pratiti i usporediti na koji se način percipirala uprava kroz različite političke vladavine i kako je uvjetovala formiranje ženskih uloga i položaja unutar obitelji i društva. Slično je i s drugim obiteljima koje su uključene $\mathrm{u}$ istraživanje. Nerijetko kazivačice govore o nekoliko generacija radnica unutar iste obitelji. Takav kontinuitet industrijskog rada unutar iste obitelji uočen je kod radnica rovinjskog (talijanskog) podrijetla, što je jedna kazivačica objasnila politikom zapošljavanja koja je u TDR-u bila prisutna sve do iza Drugog svjetskog rata. Naime, prema kazivačici A. R. (1942.), zaposlenje se dugi niz godina (posebno za vrijeme austrijske i talijanske uprave) temeljilo na sukcesiji. Majke su na radničkim pozicijama nasljeđivale kćeri, na taj način (prividno) osiguravajući najvišu razinu poštenja zaposlenica.

Iako bi se iz toga moglo zaključiti da su djevojke slavenskog podrijetla dolazile u Rovinj u kasnijem periodu te da prije kasnih 1940-ih godina nisu činile dio rovinjske radne snage, povijesni izvori negiraju tu mogućnost i ukazuju na postojanje dinamičnih društvenih i migracijskih procesa i ranije. Konkretno, vezano uz predmet ovog rada, u matičnoj knjizi vjenčanih iz 1906. godine jasno se vidi podrijetlo svakog zaposlenika. Kako je u analizi matičnih knjiga navedeno, u Rovinju su početkom stoljeća zaposlene djevojke iz Buja, Trgeta, Labina, Rovinjskog Sela, Savičente, Brtonigle i Lanišća, ali se one uglavnom zapošljavaju kao služavke. Jesu li djevojke u ranim danima industrijskog razvoja dolazile isključivo zbog posla u Tvornici duhana ili je zaposlenje posljedica udaje, odnosno preseljenja u Rovinj, teško je reći. Ono što sa sigurnošću možemo tvrditi jest da se od 1920-ih intenzivira dolazak slavenskih djevojaka u Rovinj i da otad pa sve do razdoblja nakon Drugog svjetskog rata svjedočanstva govore u prilog preseljenja radi zaposlenja u jednom od industrijskih pogona.

\subsubsection{Razlozi zapošljavanja}

Ova razmišljanja temeljim na kazivanjima moje nonne Cristine. Naime, u situaciji koja se temeljila na preživljavanju od prihoda generiranima kroz sezonske djelatnosti kao što su ribarstvo i poljoprivreda na škrtoj rovinjskoj zemlji, često kažnjenoj i sušom, siguran i stalan prihod bio je ogroman resurs. Ovo se odnosi na cijelu obitelj. (A. R.) 
Iako su zaposlenja bila egzistencijalne prirode, nije isključena i društveno uvjetovana motivacija. Siromašne djevojke su se zaposlenjem u tvornici uspinjale na društvenoj ljestvici i osiguravale su si određenu razinu u donošenju odluka. Analizirajući razloge zapošljavanja kroz tri politička i organizacijska sistema, primijetit ćemo da razlike gotovo i nema. Žene su primorane raditi zbog siromaštva, a tek rijetke zbog akumulacije određenog bogatstva. Ipak i jednima i drugima će privatno vlasništvo u novcu omogućiti određenu slobodu izbora no ne uvijek i lagodniji život.

Za vrijeme Prvog svjetskog rata Tvornica duhana je zatvorena, a veliki broj Rovinjaca prisilno je evakuiran u Wagnu, današnja Češka Republika. Jedna će se kazivačica u tom kontekstu prisjetiti postojanja razlike među ženama, čak i onda kada su obje bile tabacchine.

Moja se baka s mamine strane zaposlila u tvornici netom prije početka Prvog svjetskog rata. Uskoro je tvornica zatvorena, djelomično i zbog prisilnog preseljenja talijanskog stanovništva koje je naredila Austro-Ugarska. Moja se majka rodila u groznim uvjetima u selu blizu Brna 1916. godine. Moj se tata rodio iste godine, ali u bolnici u Grazu. Nakon što se porodila, moju je baku s tatine strane posjetila vojvotkinja Zita Burbonska, koja je bila u usputnoj posjeti bolnici. Zita je mami čestitala na tečnom talijanskom, s obzirom da je sama bila talijanskog podrijetla. Tada je sve novopečene majke nagradila sa po 6 kg brašna, što je tada bilo jako puno (A. R.).

Čak je i u ovakvim, ratnim uvjetima, klasna pripadnost generirala razlike među Ženama izbjeglicama: iako su obje bile industrijske radnice, jedna je iseljena i smještena u barake u Brnu, dok je druga boravila u Grazu i porodila se u bolnici. Isto je bilo moguće zahvaljujući obiteljskom bogatstvu njenog supruga. Ova nam je informacija značajna ne samo zbog mogućnosti analize različitih uvjeta zbrinjavanja prisilnih migranata i klasnih razlika koje su diversificirale te uvjete već i zbog činjenica što dokazuje da zaposlenje u Tvornici duhana nije bilo rezervirano samo za najsiromašnije slojeve. U tvornicama su radile i dobrostojeće djevojke, moguće da bi stekle određenu neovisnost od supruga.

Informacije o nedaćama međuratnog perioda na temelju kazivanja brojnih Rovinjaca donosi povjesničarka Gloria Nemec. Ona između ostalog navodi mučne 
iskaze o gladi i siromaštvu. "Sestra mi je pričala da su mami davali nešto brašna, ali nije bilo nikakvih začina. Tata je bio ličilac, pa je imao ulje od lana. Mama je to koristila da bi začinila palentu. Sjećam se da se sve lijepilo za zube. Sjećam se da je mama željela da ostanemo u krevetu. Govorila je da ako ustanemo onda ćemo jače osjećati glad" (Nemec 2012: 60). Kazivači navode i da "Za vrijeme fašizma, Tvornica duhana postaje mjesto privilegije. Bila kiša, vjetar ili nevrijeme, 20 lira dnevno je bilo osigurano. A tako nešto nisi imao nigdje, tamo je plaća bila sigurna. Nije bilo nikakvog posla pod Italijom, sve je bilo uništeno, ekonomija je bila u komadićima" (ibid: 57).

Razdoblje nakon Drugog svjetskog rata donosi jednake nedaće. Siromaštvo i želja za osamostaljenjem prevladavaju kao razlozi zaposlenja. Međutim, s pripajanjem Istre Jugoslaviji, tržište rada se snažnije otvara i za radnice iz ostalih dijelova Istre, ponajviše za one iz ruralnih krajeva koje se zaposlenjem u tvornici nadaju boljem životu izvan dotad statičnog, patrijarhalnog i iznimno teškog težačkog života. Kazivanja obiluju takvim navodima. Kazivačica iz Rovinjskog Sela zaposlena u Mirni 1948. sa sedamnaest godina će reći:

Oni put su uzimali sve u Mirnu i ja san mislila ma ča, najbolje da gren delati. Smo bili velika familija, zemljoradnici. Četiri brati oženjeni, svi ... zajedničko i dice nas je bilo puno i sve. Ne znan ča mi je došlo na pamet ma najbolje da gren delati. (A. $\check{\text { C.) }}$

Druga kazivačica koja u Rovinj dolazi 1951. također iz obližnjeg sela sa svega šesnaest godina, otkrit će još jednu karakteristiku deruralizacije, a koja je usko vezana uz način odabira destinacije.

U ono vrime ni bilo toliko teško za naj perke su bile fabrike, su bile bolnice, su bile neka druga poduzeća, je bilo malo drugajče, ja san imala 16 lit san došla delati.

A zašto baš u Rovinj?

Zato šta je bila još jedna iz moga sela, iz drugoga sela još su bile jedno dve, tri tako jedan s drugen i pomalo, kad to tako dojde, tako je bilo i će bit dokle je svita. (M. A. P.)

Djevojke sa sela u Rovinj su dolazile zajedno, više njih, a nerijetko su dolazile kod rođaka koji su ovdje već stanovali.

Kako to da ste došla u Rovinj?

Je bia turizam, fabrike. 
A zašto ne u Poreč, na primjer?

Ne, ne, san imela tetu u Rovinju i kod njih san šla spati.

Onda je bilo vajk puno ribe, sardoni, je bila jena sala sve po tleh [podu], to je bilo triba delati. Dosta san provala...uvjeti rada, delat doma a doma $u$ Leprinćanima puno zemlje [prije zaposlenja u tvornici]. Tamo san šla u školu jenu talijansku i četire hrvatske [razreda].

I ste delala kampanju tamo?

A smo morali [tužnim glasom], itekako. Od 7 godina smo delali, čuvali blago po dažu i po zimi. Smo imeli blaga puno i zemlje, smo delali po čitav dan. Naš tata nas je tira delati, on je bia jako za to. To se mora danas upraviti ako moreš ako ne moreš. delala sam doma previše, ča da van rečem, ne samo ja i mama i sestra i teta. (M. J.)

Kao četvrti primjer navest ćemo kazivanje u kojem je sažet specifičan pogled na život uvjetovan tadašnjim životnim prilikama. Želja kazivačice da se odmakne od teškog života na škrtoj istarskoj zemlji i uskog kruga obitelji gotovo je amblematska.

Ja san pošla od petnaest lit ća. Ja sa sela nisam... Ja sam vajk bila takova, nisam njanke baciljala ...

Ja sam pošla lipo u Pazin, iskati delo... Lipo sam iskala da bi se učila šiti. Niš nigdje. Onda sam pošla je bio taj hotel mali u Pazinu, sam pošla pitat... Ne, ne, ne, ne treba. I ja na poljoprivrednu školu. Tamo je bia direktor Zidarić iz Lindara. 'Dobar dan, dobar dan'... 'O, dobar dan! Šta je mala?'... Ja sam rekla 'Tražim posao'... 'Da, nam treba jedna mala'... Je reka 'Lipo pođi u Lindar sutra, sada ne. Pođi sutra u Lindar, tamo na općinu'... I gren ja tamo, san rekla 'Dobar dan, dobar dan... San došla. San si našla delo u Pazinu. Me poslao direktor Zidarić da mi napravite dokumente jer će me uzeti na delo'...(M. G.)

\subsubsection{Politike zapošljavanja}

Za vrijeme Austrije kontrolori su bili Austrijanci, za vrijeme Italije Talijani, a za vrijeme Jugoslavije su postavljali svoje ljude, najčešće iz Dalmacije, izvana. Oni su nam bili šefovi. (M. R.)

U prvom valu zapošljavanja brojne prijavljene žene nisu dobile posao (podsjetit ćemo se, od prijavljenih 700 djevojka samo je 391 bila zaposlena u prvom valu) što jasno ukazuje na višak radne snage u samom Rovinju i veliki interes za zaposlenjem. Slijedeći tu logiku, možemo zaključiti kako uvoz radne snage nije bio potreban, posebno ako uzmemo u obzir da je osnutku Tvornice kumovalo pismo gradonačelnika Campitellija u kojem navodi mnogobrojnu raspoloživu žensku radnu snagu u Rovinju koja ne može na drugi način steći osnovna sredstva za život. Kako smo ranije ukazali, 
najranija politika zapošljavanja temeljila se na principu sukcesije, osiguravajući tako, prema tadašnjoj upravi, najvišu razinu poštenja radnica. Kćerke su nasljeđivale majke, a s obziorom da je Rovinj obilovao vještim ženskim rukama, broj strankinja je za vrijeme Austrije zaista ograničen.

Nakon moje prabake, od četiri kćeri, dvije su išle raditi u Tvornicu. (M. R.)

Međutim, ako znamo da je 1885. godine Tvornica zabilježila rekordan broj proizvedenih cigara $\mathrm{i}$ da se snažna ekonomska aktivnost zadržala sve do Prvog svjetskog rata, za pretpostaviti je da su se i djevojke iz okolnih sela mogle zaposliti u TDR-u. U povijesnim smo dokumentima našli dokaze koji govore u prilog tome da su djevojke slavenskog podrijetla, koje su u prvom desetljeću 20. stoljeća dolazile u Rovinj, dolazile najprije zbog posla, a rijetke su uspijevale posao pronaći i u TDR-u. Takvi su primjeri bili iznimka, pa kulturno sjećanje pamti samo Rovinjke kao prve zaposlenice TDR-a. Prisjećajući se prabake koja se među prvima zaposlila u Rovinju, kazivačica M. R. (1940.) će reći:

Činjenica je da se Slavenkama ili Hrvaticama bilo teže zaposliti u TDR-u s obzirom da je u to vrijeme bilo još puno Rovinjki koje su se htjele zaposliti. Tvornica duhana je bilo puno više talijanizirana od Mirne. Mirna je puno prije počela uzimati i Hrvatice. A razlika je bila i u poslu. Sve su htjele biti na suhom, ne na mokrom. 


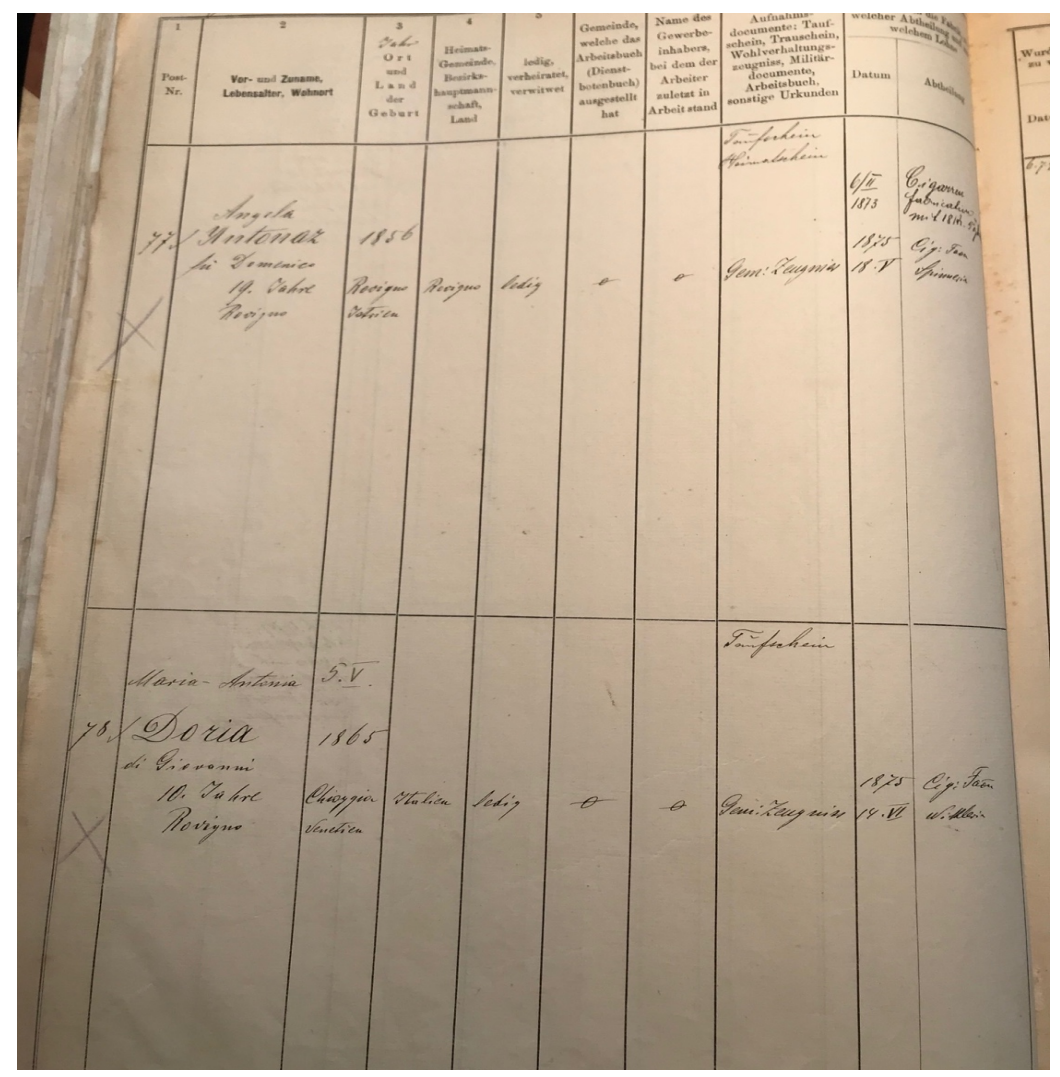

Slika 12. Izvod iz Knjige radnica, politika zapošljavanja u najranijoj fazi Fotografija: Kristina Miljavac

Po završetku Prvog svjetskog rata, 1919. godine talijanska je vlada ponovno otvorila pogon, a s konačnim prijelazom pod talijansku jurisdikciju tvornica postaje dijelom državnog monopola - Monopoli di stato italiani. Poslijeratne nedaće prema nekim su autorima vrlo brzo nadiđene. Gabriele Bosazzi (2012) će navesti da je već 1923. godine Tvornica vratila produkciju na razinu predratnih godina, zapošljavajući 840 osoba u samoj glavnoj tvorničkoj zgradi, ali i u novootvorenim prostorijama (barakama) za sušenje duhana na obroncima Rovinja, kao i plantažama duhana $\mathrm{u}$ Svetom Petru u Šumi i Balama (Nikolić Đerić 2015: 178). Ipak, prividni rast tumačen kroz prizmu kvantitativnih statističkih podataka pokazao se manjkavim. Džeba će navesti da se odnos Talijanskog monopola ne može shvatiti izvan konteksta opće ekonomske politike Italije prema Istri, a koja je istarsku privredu podredila vlastitim interesima. Isto se ogleda u povlađivanju talijanskim proizvođačima vina tako što se $u$ Istri poticala sadnja pšenice na račun vinograda ili potenciranju talijanskih ljetovališta nauštrb Brijuna ili Portoroža. Osim nefunkcionalnim strojevima koje je Italija dopremila u zamjenu za postrojenja Tabak-regie, preseljenih još za vrijeme rata $\mathrm{u}$ 
Austriju, Talijanski je monopol rovinjsku tvornicu unazadio i odlukom da proizvodi najlošije cigarete na tržištu. Kruna ovakvog odnosa ogledala se u politici zapošljavanja koja je "otvoreno davala prednost talijanskom življu, onima koji su podržavali novu vlast, ili, nerijetko, onima koji se nisu ustručavali podmititi nekog rukovodioca." Prema iskazu kazivačice da je svaka uprava imala svoje (nacionalno ili politički podobne) rukovodioce, tako i Džeba navodi da problem nije bio toliko u rukovodstvu s obzirom da se austrijska praksa zapošljavanja austrijskih i mađarskih nadglednika na neki način nastavila, samo su sada nadglednici bili Talijani. Ono što je unijelo pomutnju među stanovništvom i radništvom bile su politike zapošljavanja radništva (Džeba 1987: 84$85)$.

Ove politike i ekonomske odluke reflektirale su se dakako na zadovoljstvo radnika. Prisjetimo li se iskaza kazivačice M. R. da su za vrijeme fašizma već počeli zapošljavati podobne i dodamo li tome iskaz A. D. Q. da se njezina majka nije mogla zaposliti u Tvornici, i to ne samo zato što nije bila Talijanka već i zato što nije bila upisana u fascio, otvorit će nam se nova intersekcija, ona političke pripadnosti. Kazivačica će otvoreno govoriti o tome da su se za vrijeme fašizma uz Talijanke iz Rovinja u Tvornici zapošljavale i slavenske djevojke iz (dobrostojećih) fašističkih obitelji. Ništa lakše nije bilo ni u Labinu, u kojemu su pod zemljom u i inače teškim uvjetima radili muškarci. Matošević navodi iskaze kazivača, rudara, koji svjedoče o teškom fašističkom periodu: "pod Italijo, Italija je vladala 25 godina tu, kad je šla ća najslabije je pasalo (A. V. intervju)" (Matošević 2011: 162). Dakako da je poslijeratni period obilježen siromaštvom snažno utjecao na opće stanje i percepciju, a strategije zapošljavanja (pa i priklanjanje fašizmu) za mnoge su značile preživljavanje.

Tata [rovinjski Talijan] je sve pokušao kako bi se mama zaposlila u tvornici duhana i jednostavno nije bilo moguće. Ali su na primjer u tvornicu ulazile [zapošljavale se] Slavenke iz Rovinjskog Sela kao na primjer M. B. jer oni su bili, e...znalo se da su fašisti. (A.D.Q.)

U takvoj osiromašenoj i politički 'okupiranoj' Istri, otvara se još jedna tvornica duhana, ona pulska. Ista je, kao i ona senjska desetljećima ranije (usp. KolarDimitrijević 1979 i Marsetič 2016.) otvorena zbog socijalnih razloga, kako bi se pomogla privreda ratom devastiranog grada. I pulska je tvornica, dakako, bila pod 
upravljačkom palicom državnog monopola. Povjesničar Raul Marsetič 2016. godine objavljuje arhivski materijal u kojem se navode zahtjevi poslodavca prilikom zaposlenja. Djevojke su morale imati najmanje 17 i najviše 22 godine, talijansko državljanstvo, najmanje tri završena razreda, prebivalište u Puli, morale su dokazati da znaju čitati i pisati na talijanskom jeziku te da nisu osuđivane. Na posao su se redom prihvaćale najprije ona najmlađe i najsnažnije tjelesne konstitucije. Rang lista prema tim kriterijima je javno objavljena (Marsetič 2016: 83).

Ponovnu drastičnu promjenu u politikama zapošljavanja tvorničke radnice doživljavaju po završetku Drugog svjetskog rata. Osim desetkovanog, a kasnije nacionalno podijeljenog socijalnog tkiva i devastirane ekonomije, novo socijalističko uređenje pred radnike stavlja dodatni izazov - samoupravljanje. Zakon o predaji državnih poduzeća na upravljanje radnim kolektivima donesen je 1950. godine (Džeba 1987: 92). Period između 1947. pa sve do prvih godina 1950-ih bio je posebno tmuran, upravo zbog velikog broja osoba koje su napustile Rovinj. Bile su to zaista tužne sudbine. Moj je djed ostao jer je njegov otac, odnosno moj pradjed bio bolestan. Iako su sestre, dakle moje tetke htjele otići za Italiju, majka im je odgovorila da ne može otići s četvoro djece, bolesnim mužem i starcima. Moja mi nonna uvijek priča kako je obitelj (u koju se udala) ostala u Rovinju, a što je u konačnici i omogućilo da upozna nonna Giovannija i da s njim osnuje obitelj. Iz tog su braka rođene moja majka Antonella i tetka Silvana.

U Pazinu je počelo biti mancanza del lavoro [manjak posla] kako bi se reklo... Jer to je bila poljoprivredna škola $i$ to se je valjda zatvaralo i to nas je bilo kao viška... ali ja sam sama dala tamo otkaz i došla za Rovinj jer smo čule da traže ljude za u tvornicu, a za koju, ja nisam znala. Evo, kad sam došla, onda je bilo za tvornicu sardine i sam si našla stan...(M.G.)

"Nedaće je zaokružila fluktuacija radnika. Stavljeni pred mogućnost opcije, dosta je iskusnih duhanskih radnika i majstora za održavanje strojeva talijanske narodnosti odlučilo nastaviti život u Italiji. Njihova su mjesta popunjavali novi radnici, pretežno sa sela, kojima je to bilo prvo radno iskustvo s industrijskim načinom rada i života” (Džeba 1987: 91). Takav stav ponovio je i generalni direktor TDR-a Dušan Kolić u TV emisiji "20 miliona - sve zbog jednog cigarilosa", snimljenoj u Rovinju 
1968. godine i prikazanoj u sklopu programa RTS Trezor, a povodom jedne od kontroverzi vezanih uz papir korišten za ondašnje cigarete.

Onda su došli ljudi i od Barata i s preko Drage od Tinjana, to su došli ljudi kadi su bile kuće prazne jer Talijane su bili sve iselili ća i onda su bile kuće prazne, polja prazna... (M. G.).

Pretpostavku o fluktuaciji radnika dodatno osnažuje iskaz kazivača koji Gloria Nemec navodi u svom radu: "Moja je mama bila tabacchina, Talijanka i maestra cigara, ali 1947. je morala napustiti posao jer su joj rekli: 'Mi ne želimo maestre', dakle trebalo je sve uništiti, kako bi se promijenio prijašnji sustav. I tako su je otpustili” (2012: 370). S obzirom da se izjave novopridošle uprave koje žale za dobrim radnicama, kose s izjavama potomaka tabacchina, teško je reći je li politički pritisak bio jači od ekonomskog. Činjenica je da su tabacchine imale mogućnost optirati za odlazak i da ih je u Italiji čekao posao u nekoj od državnih tvornica duhana. S obzirom da je veliki broj rovinjskog talijanskog stanovništva napustilo grad te kobne 1947. godine situacija u tvornici duhana zasigurno nije bila laka. Utjecaj na profitabilnost tvornice koju su imale maestre cigara bila je nemjerljiva, no dolazile su nove žene s novom snagom.

Ja san rođena 1929. i '48. san došla u Rovinj delat u fabriku. Stali smo dobro jer smo imali kampanje, ali samo od fabrike ne bi bilo. (A. D.)

Ja san već 1948. [s trinaest godina] došla iz Španidige, smo bili veliki siromahi. Ali u fabriki san počela 1951. jer zbog lita nisan mogla ranije. Sestra je već delala. (A. S.)

Većina kazivača talijanskog podrijetla su potomci onih radnica koje se 1947. napustile Rovinj. Stoga su njihova sjećanja najviše vezana uz razdoblje talijanske uprave s vrhuncem u kratkom poslijeratnom periodu koji je bio traumatičan za radnice i njihove obitelji. Tako će se jedan kazivač prisjetiti.

Ja sam uz nju [tetku] odrastao jer je moja mama rano ostala udovica, a radila je u tvornici. Tako je teta došla s mojim mamom Aurorom u Firenze. Mama je bila tabacchina i je dobila premještaj nakon rata. (T. L.)

Jedna od mojih kazivačica značajno će upotpuniti gore navedena kazivanja otvarajući novi pogled na mogućnosti intersekcijske analize ukazujući na zamršene intersekcijske uzorke. 
1947. godine moja je majka s još desetak tabacchina dobila mogućnost preseljenja i zaposlenja u Veroni, u tamošnjoj tvornici duhana. Među njima su bile i dvije Slave [Slavenke] iz unutrašnjosti, dakako jasno ti je da nisu bile komunističkog duha! (A. R.)

Ovim nam je iskazom indirektno još jednom potvrđeno da su se pojedine djevojke slavenskog podrijetla za vrijeme talijanske uprave $u$ TDR-u zapošljavale prema političkom opredjeljenju, odnosno ukoliko bi se priklonile fašizmu. Uz to, kazivačica talijanskog podrijetla dodaje:

Mislim da dvije od deset ukazuje na dobar primjer integracije. (A. R.)

Zaključak kazivačice je problematičan na minimalno dvije razine. Najprije u sagledavanju činjenice da su se djevojke iz obližnjeg sela morale integrirati u državnoj (ne lokalnoj, privatnoj!) tvrtki implicira da su pojedine žene imale status drugog reda. Pitanje koje se otvara je je li im je taj status uvjetovala nacionalnost ili ruralno podrijetlo. Dalje, očigledno neravnopravne stanovnice iste države, nisu se integrirale (u tvornici na radnom mjestu!) kao radnice, dakle osobe koje dobro obavljaju svoj posao, već kao fašistkinje.

Novi politički i organizacijski model u ovom se pogledu nije puno razlikovao od onog prethodnog. Osim činjenice da su najbolje radnice napustile grad zbog političkih razloga, oni koji su ostajali bili su suočeni sa sličnom nacionalno uvjetovanom diskriminacijom prilikom zapošljavanja ili zadržavanja posla. Prisjećajući se svog supruga, kazivačica će reći:

Onda tamo [u jednom turističkom poduzeću] nije baš bilo dobro. Onda su gledali, e, ti si Talijan, tebi ćemo dati otkaz. To je bilo za vreme Jugoslavije. I tako da je bija tamo dobija otkaz pa su ga uzeli na brod, neki Luciano Pace je bija kapetan broda i tamo je bija motorista. (M. G.)

Intersekcionlizam nas uči sagledavati različite 'kombinacije' elemenata koji mogu doprinijeti opresiji. U gore navedenim primjerima zorno je prikazana intersekcija nacionalnog, klasnog i političkog, ali nam iskustvo muškarca koji je nacionalno nepodoban u kontekstu radničke pozicije nameće nužnost preslagivanja intersekcijskog modela i prihvaćanja različitih uzoraka pri generiranju opresije. Činjenica da je on muškarac nije bila dovoljna u trenutku kada je društvo pogođeno ekstremnim političkim promjenama. 
Iz škrtih podataka koje imamo o najranijoj povijesti tvornice za preradu ribe, možemo zaključiti da su se slične politike zapošljavanja odnosile i na taj pogon. Međutim, s obzirom da posao sardelline nije bio toliko prestižan i tražen, moguće je da je konkurencija bila manje naglašena. U najranijoj fazi ovdje se zapošljavaju Rovinjke koje su siromašne i ne uspijevaju naći posao u tvornici duhana. Podaci iz matičnih knjiga ukazuju i na činjenicu da na prijelazu stoljeća u Ampelei rade i djevojke slavenskog podrijetla iz drugih istarskih gradova. Iz rijetkih kazivanja koja prenose neka obiteljska sjećanja saznajemo i to da se tvornica za preradu ribe ranije otvorila zaposlenju Hrvatica (v. ovdje str. 106), no ne znamo na koji se period kazivačica točno odnosi. Kako se 1920-ih godina migracije sve više intenziviraju, tako je sve više djevojaka slavenskog podrijetla iz obližnjeg sela nastanjeno u Rovinju.

Moja mama je rođena 1920. u Voštenima i za vrijeme Italije je došla i je radila u Mirni. Nas je zgojila sedam djece. (D. C.)

Kako je u više navrata naglašavano, politike zapošljavanja za vrijeme Jugoslavije se mijenjaju. Mogućnosti zaposlenja slavenskih djevojaka su naizgled veće, međutim ograničenje ipak postoji s obzirom na prestiž tvornice duhana i prevelik broj zainteresiranih radnica opterećenih siromaštvom poraća i ohrabrenih novim prilikama socijalističkog poretka. Posebno je važno naglasiti nagli industrijski razvoj u sklopu kojega su Mirna d.d. i TDR bili samo kap u moru mogućnosti, posebno u odnosu na brzorastući turistički sektor. Prisjećajući se svog preseljenja u Rovinj 1952. godine kazivačica objašnjava:

Čule smo da tražu ljude za u tvornice, a za koju ja nisam znala. Evo, kad sam došla, onda je bilo za tvornicu sardine. (M. G.)

Kazivačica zaposlena 1948. u Mirni također će naglasiti koliko je bilo lako naći posao, posebno u Mirni.

Oniput su uzimali sve u Mirnu i ja san mislila ma ča, najbolje da gren delati. ...

U fabriku tabaki su zimali samo neke ki su mi rečemo poznali, imali kontakt s njima i nismo bile sve, kad nisi nikad na delu ne znaš kako je. (A. Č.)

Primjećujemo da je zaposlenje u tvornici duhana čak i po otvaranju prilika za slavenske djevojke i dalje bilo veoma traženo i ograničeno. Kazivačica naglašava nužnost poznanstava i bivanja u određenom radničkom miljeu kao jedan od uvjeta zaposlenja. 
Međutim, ekonomski odnosi se vrlo brzo mijenjaju. Tvornica duhana je ponovno oslabljena nedostatkom iskusnih motačica duhana, nedostatkom sirovine na svjetskom tržištu i lošom mehanizacijom, a nova država sve više ulaže u riblju industriju.

Mirna je jako jako dobro stajala. Je pomagala i fabriki tabaka. Smo imali brodove i vamo i tamo, i ulov je bio jako dobar, je bilo puno dela a sad nema ribe. Znaš zašto nema ribe? Jer je more jako toplo. Njanke karamaji [lignji] ni. (D. C.)

Od 1960-ih čini se da se mogućnosti zaposlenja izjednačavaju u obje tvornice. Kazivačica iz Kanfanara zaposlena u Mirni 1961. će reći:

Ja sam pitala da li se more dobit ili Fabrika Tabaka ili ovo pa sam bila dobila i od TDR i od Mirne. Sad nisam znala kamo da idem. A moj muž 'zberi si šta ćeš'. Neko govori Mirna bolje stoji ajde ti hodi u Mirnu i tako sam otišla u Mirnu i bila 22 godine. Svako delo sam znala u fabriki. (S. V.)

Uvidom u različita sjećanja i stavove o tome jesu li se ili nisu, i pod kojim uvjetima zapošljavale djevojke slavenskog podrijetla, možemo jasno ukazati na heterogenost iskustava i sjećanja, dakle mehanizama pamćenja. S obzirom na navedeno, vrijedilo bi analizirati Knjige radnica iz tog perioda kako bi se usporedila kazivanja i broj stvarno zaposlenih radnica netalijanskog podrijetla. Pritom valja imati na umu sljedeću potencijalnu zamku. Nemec navodi kako su zapošljavali djevojke sa sela, ali su im mijenjali imena i primoravali ih da govore talijanski. Pitanje je na koji su način tada vođene knjige i je li moguće naknadno jasno razlučiti njihovu nacionalnost ako je postojao takav pritisak talijanskih vlasti (ibid.).

\subsubsection{Tehnološki procesi rada}

Svugdje u carstvu prerada duhana je bila posao žena i djece (Džeba 1987: 60).

Proizvodnja duhana podrazumijevala je sušenje i oblikovanje listova duhana $\mathrm{u}$ cigare, a od 1886. i cigareta. Iako je rovinjska tvornica, slijedeći svjetsku revoluciju u pušenju, vrlo brzo započela s izradom cigareta, cigare su se i dalje proizvodile i zadugo su ostale njezin najvažniji proizvod. "U prvoj godini rovinjska je tvornica bila opremljena s 13 različitih strojeva: četiri su motala cigare, jedan je služio za pakiranje, jedna je presa bila za bale a druga za oblikovanje cigara, sa dvije štrcaljke se vlažio duhan, a na raspolaganju su bile i 3 sušionice" (Džeba 1987: 60). Džeba nas informira 
da je "1885. tvornica (je) ugradila prve motore, čime je iz manufakture zakoračila u mehanizaciju proizvodnog procesa (...) međutim, većina od 155 različitih strojeva $\mathrm{i}$ naprava i dalje je ovisila o snazi ljudskih ruku" (ibid.: 72). Da uvođenje razmjerno velikog broja strojeva ne treba smatrati potpunom radnom promjenom kada govorimo o tvornici duhana, a koja manufakturnu proizvodnju cigara zadržava do 1945., autor tvorničke monografije argumentirat će činjenicom da izrada najfinijih cigara još i danas ovisi o spretnosti ženskih ruku (ibid.: 73). S time $\mathrm{u}$ vezu dovest ćemo tvrdnje ekonomskih povjesničara koji tvrde da su za rad u tvornicama (posebno u drugom industrijskom razdoblju koje je već dovoljno mehanizirano; rad na traci) potrebni niskokvalificirani radnici koji su pronađeni u ženama i djeci, međutim naše tvornice $u$ tome periodu (druga polovina 19. stoljeća) još nisu prošle de-skilling fazu, te potpuno suprotno navedenom, u kasnijim fazama mehanizacije kada rad ženskih ruku mijenjaju različiti strojevi, žene sve više zamijenjuju muškarci. Postavlja se pitanje je li moguće da su za proizvodnju cigareta bile potrebne vješte ženske ruke, dotad navikle na šivanje i vezenje, a za slaganje sardina u male kutije jednako takva minucioznost, preciznost i brzina koje odlikuju neke žene. Nije li, uostalom, vjerojatnije da su investitorima odgovarali niži troškovi rada? Podsjetimo, plaće žena i muškaraca nisu bile iste. Muškarci su krajem 19. stoljeća u prehrambenoj industriji zarađivali 12 austrijskih kruna tjedno, žene 9, a djevojčice (punoljetnost se stjecala s 14 godina) koje su tek učile posao 6 kruna (Budicin 1997: 439). Ne čudi stoga što su veliki dio radne snage činile žene i djevojčice. Krajem 19. stoljeća Rovinj je grad s nekoliko tvornica u kojem 90\% radne snage čine žene, grad s oslabljenim primarnim sektorom i desetkovanom muškom populacijom. ${ }^{86}$ Uvjeti su povoljni za razvoj onoga što će kasnije Predrag Grubić nazvati rovinjskom duhanskom (radničkom) (sup)kulturom (Grubić 1999: 30). Dodajmo k tome da se od 1830-ih, a posebno nakon 1848. godine, tržište drastično mijenja, pa naviku pušenja lule smjenjuje navika pušenja ručno rađenih cigara (Fellner i Thiel 2009: 38$40)$.

\footnotetext{
${ }^{86}$ Benussi navodi kako je 2300 osoba otišlo na rad u Pulu (velika većina kojih su muškarci s obzirom na to da su se zapošljavali u Arsenalu), njih $800 \mathrm{u}$ druge gradove Carstva, 300 u druge europske države, a njih čak 1400 na druge kontinente (Benussi 2004 [1888]: 286). Krajem 19. stoljeća uobičajeno je da u druge zemlje i na druge kontinente emigriraju muškarci, koji su odlazili raditi s idejom da će se nakon nekoliko godina vratiti. Vrlo su rijetko odlazile žene ili čitave obitelji.
} 
Proces proizvodnje cigara podrazumijevao je najprije odabir odgovarajućeg lista koji nije imao napuknuća. Trebalo ga je zatim napuniti duhanom, cilindrično umotati i zalijepiti s malo ljepila. Smotuljak se poravnavao specijalnim rezačicama i smještao u kutiju s utorima, za svaku cigaru pojedinačno. Tako su se uniformirale dužina i dijametar proizvoda. Za takav repetitivni rad bio je potreban oštar vid i vješti ženski prsti. (A. R.)

Na pitanje o razlozima zašto su baš žene radile u duhanskoj industriji većina kazivača odgovara da je tome tako jer su žene spretnije.

Žene će bolje radit. Muški su manje napredni od žena, oni moru fizički više delat, ali žena razmišlja, dobro izuzetki su izuzetki i s jedne i druge strane, se kapimo. Ali žena razmišlja više i zašto ona se našla u više deli delat, ki muški ne bi to nikad. A vjerovatno žene imaju i drugi opip ruku i nešto drugajče za delat, ne može muškarac da će on to delat, on pole zavije španjulete da bi fuma. (M. A.)

Iako su strojevi uvelike ovisili o ljudskim rukama, a cigare su se i dalje ručno proizvodile sve do iza Drugog svjetskog rata, ispravnost strojeva za radnike je bila neizmjerno važna, posebno ako znamo da su u oba pogona radnice radile na normu. Priprema i snabdijevanje sirovinom ovisilo je o ljudima i mašinama. Ranije je navedeno da je austrijska uprava iselila svoju opremu još za vrijeme rata. Talijanski je monopol dopremio trošne strojeve tako da je "bila sreća ako bi neki stroj za cigarete radio barem jedan dan bez kvara" (Džeba 1987: 84). Osim strojeva radničke hale simboliziraju stolovi. Gotovo svaka kazivačica koja je govorila o vlastitom iskustvu ili o sjećanjima na svoje pretke spominje kako su tabacchine sjedile za stolom i brzo motale cigare. Da je tehnološki proces rada simbolički predstavljen stolom itekako generirao antagonizme svjedoči jedna od najstarijih kazivačica.

Kada su počele se zapošljavati Slave ja sam uvijek gledala da sjedim za stolom s Rovinjkama. (L. M.)

TDR je svoj profit dugo temeljio na proizvodnji skupih cigara. Kada je 1945. godine na temelju tržišnih trendova i socio-ekonomske situacije u zemlji nova uprava ${ }^{87}$ odlučila prestati s proizvodnjom cigara, radnice i dalje sjede i rade za istim stolovima,

87 Od 1945. do 1950, TDR djeluje u uvjetima administrativnog socijalizma, kakav je dotad vladao u Jugoslaviji, sa centralnim planom kao glavnim mehanizmom za upravljanje privrednim životom. Generalna direkcija za duhan imala je ovlasti nekadašnjeg austrijskog ili talijanskog monopola: određivala je planove proizvodnje, osiguravala sirovine, premještala strojeve iz jedne u drugu tvornicu, odlučivala o ulaganjima, preuzimala gotove proizvode i dalje ih distribuirala prema svojim planovima opskrbe.” (Džeba 1987:92) 
primjerice kod selekcije lišća. Strojevi naslijeđeni iz prijašnjeg sustava još su lošije radili, pa je odluka Glavne uprave za duhan da se ugase tvornice u Puli, Rijeci i Senju , za sudbinu rovinjske tvornice bila iznimno važna. Iz Rijeke je dopremljeno sedam strojeva za izradu cigareta, ali koji su samo nakratko prekinuli agoniju TDR-a. Tek su 1952. i 1953. u TDR dopremljena 3 nova stroja, a 1951. započet je sustavni uzgoj duhana (Džeba 1987: 93-94). Teške poslijeratne godine za radnice i radnike TDR-a, posebno od 1950. i uspostave samoupravljanja, značile su borbu za opstanak.

Fabrika je bila u škripcu najviše od 1951.-1953. ča se ja domislin. 1953. smo dobili $70 \%$ plaće. (A. S.)

Tehnološki procesi obrade duhana, osim samog motanja cigara, nisu se puno promijenili sve do 1968., kada se uvodi traka i komora na paru za vlaženje duhana.

Prva klasa duhana je bila iz Makedonije, Turske, Grčke i Bosne. Najmekaniji je bio iz Makedonije, žut kako cekin i elastičniji. Najprije je duhan bio u bagnamento [močenje] 24 sata. To smo na ruke ga stavljale, a voda je bila ledena. Onda smo sortirale. Lipo dva kasuna i dvi kašete i svaka klasa; zeta, drava, morava, u jedan kraj. Kad smo načinile kasun su spezali [izvagali] i su pošle u mišelu [na miješanje]. $700 \mathrm{~kg}$ je stalo unutra. I onda se opet močilo. Opet 24 ure. Nakon mišele na tri dijela se vadilo i se hitalo [bacalo] na platno. Opet se spezalo i onda je pošlo na trinciatura [rezanje, usitnjavanje]. Bile su četire makine, četiri muška su radili. Onda na makinu, poluautomatsku, u hartu se motalo pa na pakovanje. Sve ručno škatule [kutije] od sto cigareta. Si uzimala colu [lijepilo] i ručno zatvorila.

1968. je došla linija, traka i parna komora. Je bilo lakše, ali se smanjio broj ljudi. Rezačica je bila jedna a ne četiri, a di se listalo nije više bilo nikoga. Makina nakon trake je liste delala, a odvajala otpad. Samo lišće bi onda pošlo u drugi bubanj i tu se davalo aromu. To je onda počelo za aromu. Ja san delala kao sortiračica, ali i kao stroppabusi [dijalektalno, onaj koji zatvara rupe] jer sam bila spretna za sve. Kad je ki falio ja sam znala zamijeniti. Ali onda san se bunila pa mi je šef dao da radim aromu. (A. S.)

Džeba navodi kako se radilo prekovremeno, bez naknada, subotom i nedjeljom, međutim napredak je, prema Džebinom pisanju, dostignut tek kada se TDR "prilagodio pravilima konkurentske borbe" i "poboljšao odnos s potrošačima i trgovinom" (ibid.: 95).

Paralelno s tehnološkim poteškoćama i nedostatkom duhana na svjetskom tržištu koji pritišću TDR, Mirna d.d. polako, ali sigurno unaprjeđuje svoje tehnološke procese, flotu i proizvode. Sirovina u vidu prije svega plave ribe, bila je nadomak ruke. 
”Neposredno prije II. svj. rata tvornica je prerađivala $10 \mathrm{t}$ ribe na dan (preradba ribe $\mathrm{u}$ konzerve i polukonzerve te proizvodnja ribljega brašna i tehničkoga ribljeg ulja), a bila je opremljena i postrojenjem za iskorištavanje ribljih otpadaka eksikacijom (dehidratacijom). Nakon II. svj. rata formirana je nova organizacijska struktura. Od 1946. tvornica je proširila djelatnost na pogone u Banjolama, na Lošinju i Susku, koji su se 1954. osamostalili. Početkom 1960-ih Mirna je započela proizvoditi limenu ambalažu. (...) Početkom 1970-ih tvornica je modernizirana, poboljšani su uvjeti rada, a u proizvodni su dio uvedene nove tehnologije (preradba ribe kuhanjem na pari). Rad tvornice RO Mirna Rovinj sredinom 1970-ih bio je organiziran u četiri osnovne organizacije udruženoga rada - Ribolov i brodogradilište, Industriju (radne jedinice: Prerada Rovinj, Prerada Banjole, Limena ambalaža, Hladnjača i Pomoćne djelatnosti), Trgovačku mrežu te Zajedničke službe. Mirna je 1974. proizvela 7018 t steriliziranih konzervi ribe (od toga 1393 t konzervi ribe s povrćem), 171 t nesteriliziranih konzervi ribe, 263 t usoljene ribe, 611 t ribljega brašna i 155 t ribljeg ulja. Zapošljavala je 1300 radnika (1975). Asortiman proizvoda je znatno proširen pa je do 1975. počela proizvoditi i duboko smrznute proizvode (1980. nabavljena je nova hladnjača kapaciteta 2000 t). Rasla je i ribolovna flota brodova plivaričara (osnovana prije II. svj. rata; 11 brodova 1960; 14 brodova 1972; 28 brodova 1984)" (Hrvatska tehnička enciklopedija, pristup 1.09.2019.).

Od 1945. godine dalje, službeni podaci govore u prilog tvornice za preradu ribe, iako će nam kazivačice otkriti da se i u Mirni još neko vrijeme zadržavaju stari strojevi koji se konstantno kvare. Oba su pogona organizirana po principima samoupravljanja, međutim kazivačice smatraju da nije bilo većih razlika u odnosu na prijašnje uprave. Uvijek spominju strane kontrolore (čak i kada su to Dalmatinci koji su namješteni kao šefovi za vrijeme Jugoslavije) i maestre koji su nadgledale njihov rad. Tehnološki aspekti rada u tvornici za preradu ribe u svakom se kazivanju ističu kao fizički iznimno zahtjevni. U tom se procesu izdvaja nekoliko radnih mjesta te se prema tome radnice $\mathrm{i}$ razlikuju.

Prvu godinu si bila početnik, sve si morala proć, svu fazu rada i srdelu i čistiti i prati i nositi na sunce i sušiti i ukutijavati... i onda se zatvaralo... mašinski.

$\mathrm{Na}$ suncu se riba sušila i ju se je ravnalo da bude lepo ravna... Ona je bila ko srebro luštra. Sirova je još bila. Onda se je vozilo unutra. Bila je jedna, freteza [friteza] smo zvali, to bila je nekih sigurno osam metara dugačka, unutra je ulje 
kuhalo i jedna žena s jedne strane je gurala unutra te gradele, druga je vadila van. I kad se to prohladilo, drugi dan, smo ukutijavale. Sve smo ručno držale, nije bilo automatski onaj put, to je bilo sve ručno. I onda se zatvorilo i drugi dan su prokuhali da se sterilizira... Na kraju se je stavljalo one kutije kartonske ili omotalo u tu omotnicu... Kakva je bila...kutije je bilo tri vrsta... Je bila prvoklasna di je bila sardina cijela. Nije smila biti puknjena. Pa je bila druga klasa. Pa one što su bile malo spuknute, ono je bila treća klasa. To je bila dekolaž. (M. G.)

Ribu smo najprije stakali u neke gradele ...tako smo je stavljali i smo nosili vani da se suši na neke kavalete znaš, kako oni kavaleti ča pilu drva, onako su bili. Ako je bilo ljepo vreme je bilo ljepo ma ko se spremalo da će biti ružno ajde brže teči, stori, poj opet nutra. Jo ma je bilo teško delati, sve ručno se delalo, majko mila... Onda unutra je bila jena velika, kadi se riba frigala je bilo od tuda pa valje tamo uz zid od terace je bila ta [friteza], forši i duža, puna ulja i nutra se frigala riba, se guralo te gradele nutra se friga riba i pokle se stavljalo u škatule se škatulivalo [ukutijavalo]. (M. M.)

A probali smo sve tamo u fabriki šta je bilo za radit; i ukutijavanje i ribu na mašinu sa zatvaračima i pranje i škatulanje; sve šta je bilo u Mirni smo probali. I na noge služiti žene kojima je trebalo, to su bili ovako banki, po tri banka ovako, žene bi sjedile ovako po deset žena; ja sam to volila poslužit, ja sam mogla, dizala sam... bila sam mršava ali sam sve mogla radit, bili su zadovoljni. (S. V.)

A tamo di san ja bila su bili teški uvjeti rada, ja san bila kod Brečevića [šef]. Ovako, mi smo solile barillice [bačvice] od drva. Tako 8 sati san stala. Od drva su bile i smo ih prale u sodi kaustiki [sumpornoj kiselini] i tu smo slagale ribu. Tako dvije su se dele naspro [glave su se slagale nasuprot]. (M. J.)

Iako je većina kazivačica tijekom svog radnog vijeka iskusila rad na svim navedenim pozicijama, ipak su neke od njih imale stalne pozicije ili bar omiljeno radno mjesto.

A najteže, ono što nismo mogli, to ukutijavanje. To su bile samo žene koje su bile za to. Koje su imale svoje radno mjesto. A mi, koji nismo imali svoje radno mjesto mi smo svaki dan čekali kamo će nas rasporediti, svi nismo mogli na svoje radno mjesto. Nismo ni volili, ukutijavanje je bilo malo teže, to je trebalo znat. Nije to bilo za nas, mi smo se jarmile koja će na noge nosit, posluživat žene, ja sam to jako volila i volili su nas. (S. V.)

A najviše mi se sviđalo to ukutijavanje, onda si lipo sidija i si ukutijavao. To je moja slika tamo, kad smo ukutijavale. E onda posle kad se otvorila limena ambalaža, sam prešla tamo, u limenu ambalažu, tamo je bilo lipo.

A čuj, najteže je bilo kad se s vozom vozilo. Nije bilo onaj put, ča smo mi zvali, terežina, e. Bilo se je sve ručno se radilo. (M. G.) 


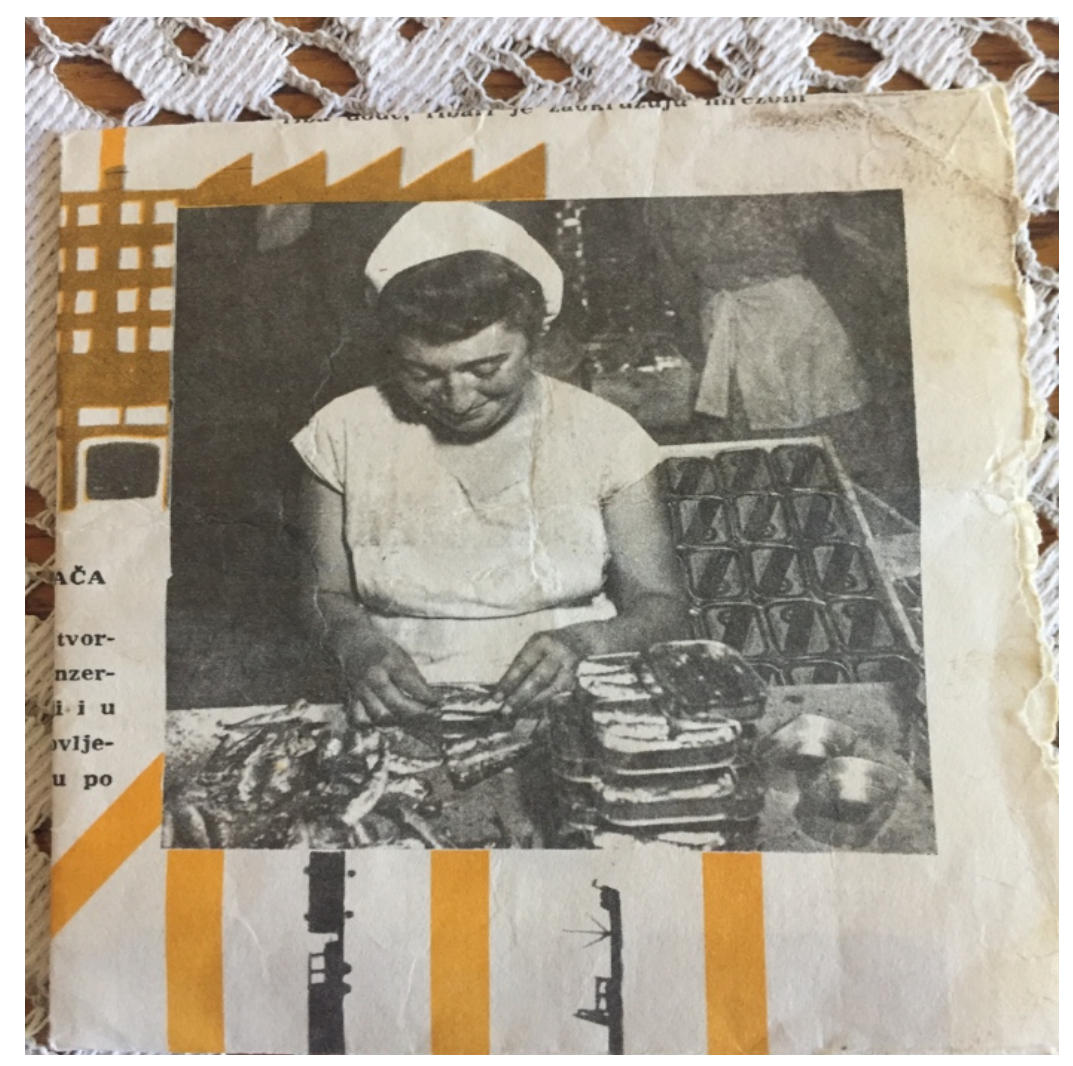

Slika 13. Kazivačica (M. G.) fotografirana za potrebe školskog udžbenika. I danas čuva isječak iz knjige.

Smo bile kako poli maše [kao na misi], stol tako dug i za se sesti. Ja san većinu delala zatvaranje kutije. I to mi ni bilo lako zatvarat te kutije, se na nogami stojiš i ručno zatvaraš ... a plus toga su bile mašine ča nisu vrijedile niš, još talijanske, stare mašine. Samo su se kvarile, mehaničar je mora popravljati. (A. $\breve{C}$.)

Ja san delala kadi je trebalo nis ima da si reka evo to je moje mjesto. Kadi je trebalo bi doša ajde digni se hoj tamo tamo, i solilo se ribu, sardine, sardone, svašta se delalo. (M. M.)

\subsubsection{Uvjeti rada}

Uvjeti rada su uvjetovani dostupnom tehnologijom i organizacijskom strukturom uključujući administrativne, legislativne i logističke aspekte o kojima je dosad bilo riječi. Iako rade $u$ formalno jednakim uvjetima, primjerice $u$ istim zakonskim okvirima i s istom tehnologijom, percepcija uvjeta rada čak i unutar iste industrije kod radnica se razlikuje od slučaja do slučaja. Tomu je tako s obzirom na različite pozicije iz kojih 
radnice dolaze. Opterećenje nije bilo jednako za mlađe ili stare, udane ili neudane, majke ili slobodne djevojke. Brojne su žene radile kod kuće i u polju nakon što bi završile smjenu u tvornici, kako bi prehranile djecu.

Mi smo imali zemlje, pa je puno maminih kolegica...one najsiromašnije, su dolazile raditi u kampanju [polje] nakon posla i mama ih je plaćala. Bile su gladne, a mama nije mogla sve sama jer je tata onda [pedesete godine 20. st.] već bio lošije. (F. Q.)

Umor i zdravstveno stanje su u tom slučaju igrali važnu ulogu u efikasnosti radnica. Radnička sjećanja su, unatoč navedenim teškoćama, uglavnom pozitivna. Ipak dvostruka opterećenost (usp. Senjković 2018: 182) o kojoj će biti riječi kasnije, je snažno osviještena. Ako usporedimo uvjete rada kroz tri politička sustava, primijetit ćemo da se uvjeti rada nisu drastično mijenjali s prijelazom iz jednog političkog sustava u drugi. Slično je i s promjenama u ekonomskim sustavima kojima tvornice svjedoče. Tomu je tako zahvaljujući već poodmakloj industrijalizaciji (u odnosu na industrijske procese 17. i 18. stoljeća) i državno-monopolističkom kapitalizmu (usp. Hobsbawm 1999). Naime, tehnologija dostignuta oko 1906.u tvornici duhana se zadržala s manjim izmjenama gotovo sve do 1968. kada se uvodi rad na traci i drugim automatiziranim strojevima. Dakle, iako se strojevi uvode oni nisu automatizirani, a izrada cigara je isključivo ručna i zadržava se do 1945. Kod prerade ribe, tehnološki uvjeti su slični, sve se radi ručno. Tek se 1960-ih godina uvodi automatizacija strojeva. Jedino su hladnjače nabavljene 1950-ih donekle poboljšale status radnica jer su osiguravale sirovinu, a time i cjelogodišnji rad radnica. Kada govorimo o uvjetima rada, državni monopol (AustrijaUgarska i Kraljevina Italija) je osiguravao relativno visoku razinu socijalne zaštite, tako da su tabacchine imale sve 'pogodnosti' i ranije, neke čak i više nego za vrijeme socijalizma. Dakle, prijelaz iz jedne vladavine u drugu, ne mijenja značajno uvjete rada s obzirom na državno-monopolistički kapitalizam koji karakterizira tadašnju duhansku industriju. $\mathrm{Na}$ žalost, čak ni promjena na samoupravljanje 1950. godine, u prvim godinama za obične radnice ne znači mnogo. Siromaštvo je sveprisutno, tvornice su oslabljene $\mathrm{u}$ financijskim, tehnološkim i ljudskim resursima do te mjere da je TDR 1953. bio skoro pred zatvaranjem. Organizacija rada iako promijenjena s pozicije uprave, za radnice rovinjskih tvornica nije predstavljala značajniju razinu kontrole proizvodnih procesa. I dalje su šefovi bili muškarci i 'stranci'. Sada to više nisu bili Mađari, Austrijanci i Talijani već direktori iz drugih dijelova Jugoslavije. Također, 
političke promjene (konkretno Ustav iz 1946. koji izjednačava poziciju muškaraca i žena) $u$ posljednjoj fazi ne utječu ni na odnose unutar obitelji u značajnoj mjeri $s$ obzirom da Rovinj već bilježi dugotrajnu aktivnu žensku ulogu ne samo u razvoju radničkih identiteta grada već i u uspostavi ravnopravnijih obiteljskih odnosa. Činjenica da se u ostalim dijelovima Hrvatske tek 1946., i to u većini slučajeva tek nominalno, obiteljski imetak dijeli na jednake dijelove i da žena ima pravo upravljati svojim dijelom imovine, za pojedine dijelove Istre, a posebno za Rovinj stvar je višestoljetne prakse.

Austrijskog se perioda svi sjećaju kao iznimno naprednog s obzirom na sve kasnije faze. U tom smislu, važno je naglasiti da se uvjeti rada uvijek sagledavaju u društveno-ekonomskom i povijesnom kontekstu. Zarada je bila stalna i omogućavala je pokrivanje osnovnih troškova.

Za vrijeme Austrije su radile po 10 sati, mislim. Ujutro, pa su imale pauzu za ručak i poslije ponovno popodne. Plaća je bila na tjedan dana, pa je prešlo na dva tjedna, poznata quindesina, a onda je počelo mjesečno. (M. R.)

Radilo se na normu, odnosno plaćene su po količini. Dominantna figura je bila maestra, najiskusnija od radnica, koja je neumorno kontrolirala da li je cigara savršena, da li je zamotana tako da se ne primjećuju napuknuća vanjskog lista, da li su veličina i dužina točne i konstantne. Ako radnice nisu dobro umotale cigare, ona bi ih odmotala i rad bi se izgubio, morale su ponoviti. Navečer su se brojale cigare, ili kad bi završile s radom jer radno vrijeme nije bilo fiksno, ali otprilike osam sati na dan. Zbog toga su najbolje prolazile one brze, precizne i spretne. Tako je radila moja nonna, a neko vrijeme i mama. (A. R.)

Međutim, usporedimo li podatke iz Knjige radnica i dokument koji su mi za potrebe istraživanja ustupile tri sestre kazivačice, potomkinje relativno imućne obitelji tabacchina, primijetit ćemo ne samo da tjedne plaće nisu bile jednake za sve radnice nego je isto vrijedilo i za mirovine. Dok je Margherita Veggian po umirovljenju zaradila 150 kruna mjesečno, Maria Brajaka, jedna od mnogih zaposlenih maloljetnica, nakon više od 30 godina radnog staža primala je mirovinu u iznosu od nešto više od 60 kruna mjesečno. Pretpostavljam da je razlika u plaćama rezultat kombinacije radne pozicije, poput sušenja lišća u barakama, razvrstavanja listova, motanja cigara, i pozicije "učiteljice-maestre" s godinama radnog staža.

Moja svekrva i teta su bile jako dobre u motanju cigareta $\mathrm{i}$ one su postale maestre i podučavale su druge. (M. R.) 
Institucija maestre nakon Drugog svjetskog rata i ukidanja proizvodnje cigara polako zamire, ali se zadržava lik kontrolorke. U Mirni se prema kazivanjima, kontrolorka nazivala i dalje maestra; ona koja podučava, a muškarci su šefovi koji nadgledaju cjelokupni proces rada.

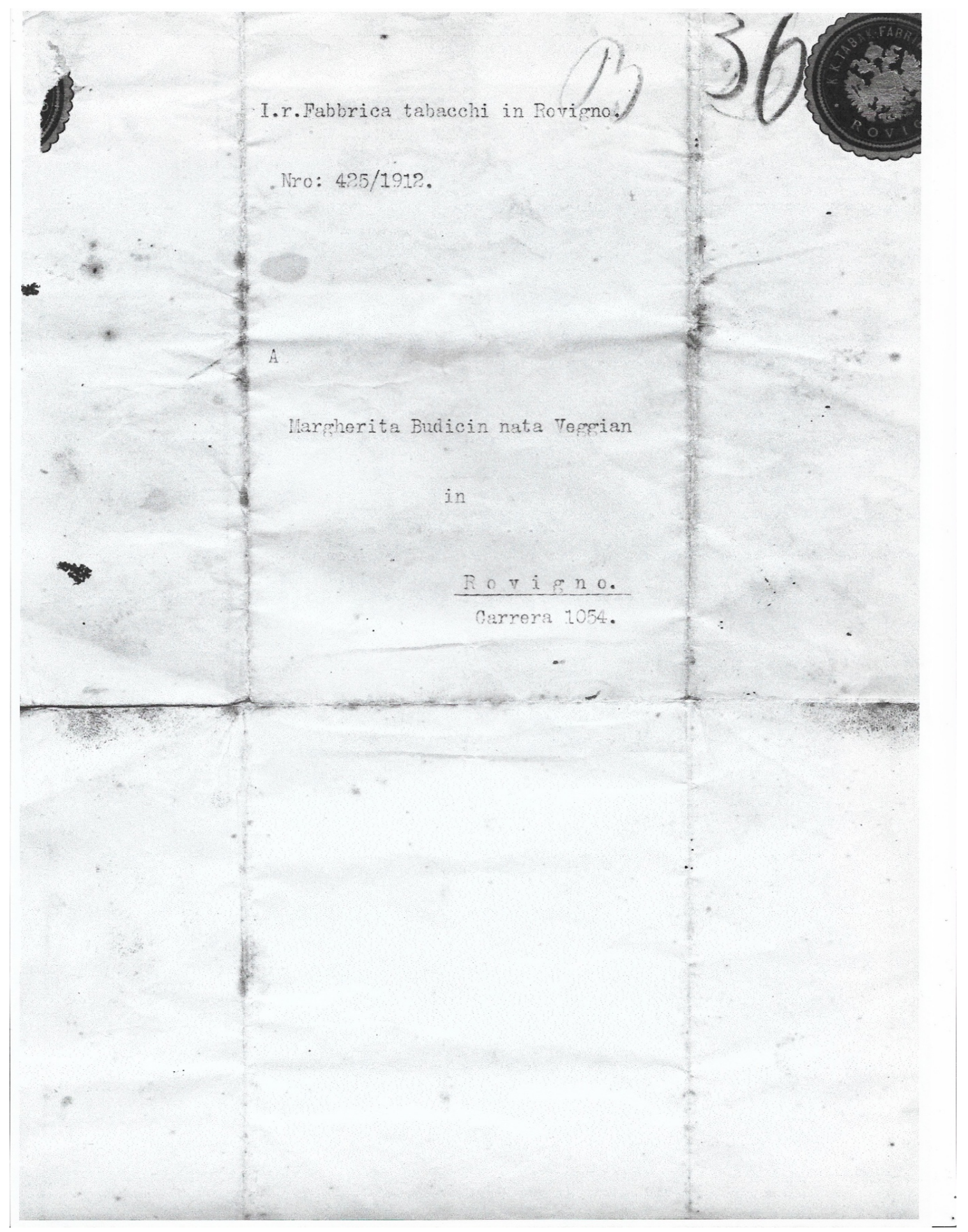


A

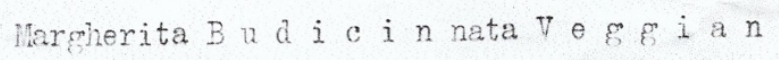

Sua Waestà I.e.R. Apostolica con sovrana risoluzione del 3 Dicembre 1911 si è graziosissinanente degnata di accordarle un'annua graziale di centocinquanta(150) Corone vita durante, oppure fino ad un eventuale protredimento con altri mezzi di sussistenza, principiando dal giorno della sovrana risoluzione.

- In tanto to si pertedipa coll'osservaziene, ehe I'i.r. Direziune di Finanza in Trieste disporrá l'opportuno per il. paqamento di questa praziale a mezzo della cassa postale di risparmio.

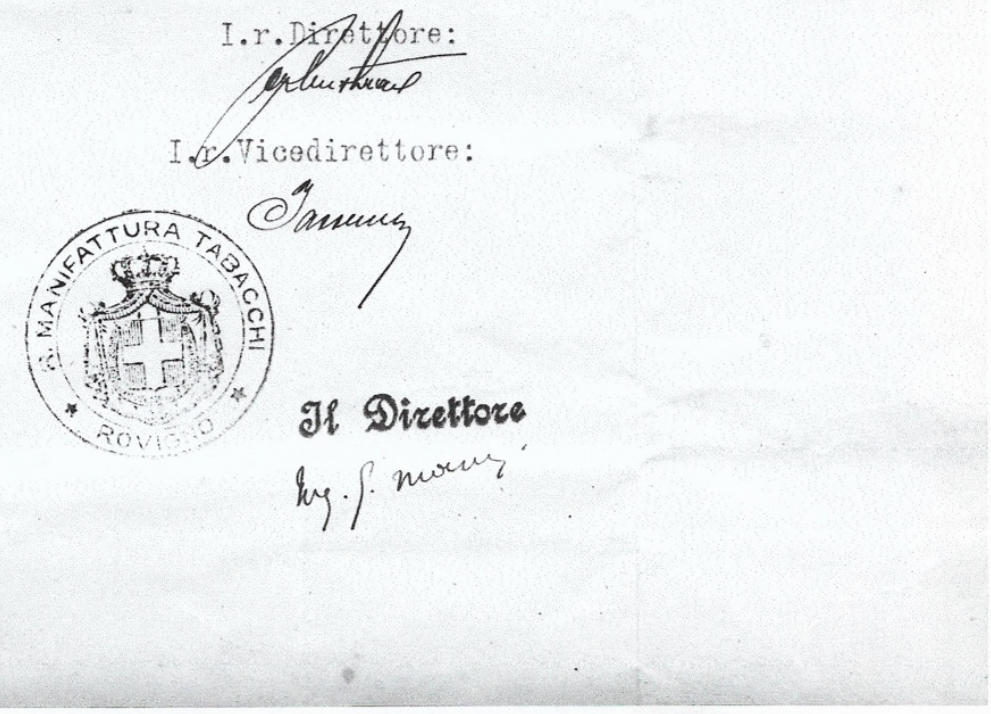

Slika 14. a i b: Pismo koje je Margherita Budicin dobila po prestanku radnog odnosa u kojem se navodi iznos mirovine ${ }^{88}$

${ }^{88}$ Kazivačice L., M. i A. C. govorile su o baki i pridonijele istraživanju vrijednim genealoškim stablom, dokumentima i obiteljskim fotografijama. 
Kazivačica slavenskog podrijetla koja se zaposlila 1948. u TDR-u s ponosom će reći:

8 lit san bila kontrolorka i to ti je onda veća plaća. (A. S.)

Kazivanje je značajno jer se po prvi put kao kontrolorke spominju žene. Žene su, govori kazivačica M. R., "do Jugoslavije u Tvornici radile cigare i do tog vremena djevojke su imale normu. Ako ne odrade normu, ne bi dobile punu plaću. Isto je bilo, ako cigarete nisu bile dobro zamotane, oduzimali bi im od plaće”. Plaću bi “oduzimali”, dakako, muškarci. Naime, ženska "moć” unutar tvornice, nije bila potpuna.

Muškarci su radili samo kao šefovi ili eventualno neke teže fizičke poslove poput fakina koji su nosili robu. (M. R.)

Osim stalne plaće, te suhog i toplog radnog mjesta, kazivačice neizostavno navode jedan od simbola austrijske uprave - cùnanbulo (jaslice). Jaslice su aktivno djelovale sve do razdoblja nakon Drugog svjetskog rata. Međutim, iako se ovakva usluga spominje kao vrhunac tvorničke socijalne politike, gotovo nijedno istraživanje ne otvara pitanja rodiljskog dopusta, broja i stručnosti osoblja koje je čuvalo djecu, emotivnih veza, odnosno poteškoća odvajanja majke od djeteta, postporođajne depresije ili fizičke (ne)spremnosti za rad nakon samo četrdeset dana oporavka od poroda. Radnice su imale mjesec i pol dana slobodno prije poroda i isto toliko po porodu.

U Tvornici duhana su imale i vrtić. Imale su slobodno sat-sat i po da bi podojile dijete, zapravo dojilje su mogle 2-3 puta dnevno otići dolje u vrtić da bi podojile dijete. Cùnanbulo je otvoren odmah za vrijeme Austrije (M. R.).

Kazivačica A. D. Q. (1947.) u šali će reći da je karijeru započela upravo u jaslicama, jer je kasnije, slijedeći stope majke i starije sestre, također radila u Tvornici, zapravo $\mathrm{u}$ novom pogonu ambalaže, Istragrafici. Druga nam kazivačica prenosi iskustvo svoje majke koja je često bila jedna od njegovateljica djece u jaslicama. Naime, jaslice su funkcionirale po principu samouprave, pa su se žene izmjenjivale u čuvanju djece. Radnicama i njihovoj djeci je od najranijih dana na raspolaganju bio i liječnik. Nepoznato je koliko je vremena provodio u tvorničkim pogonima, posebno u jaslicama 
s obzirom da su liječnici bili malobrojni, te su najvjerojatnije dolazili po potrebi. Na fotografiji iz 1943. godine figurira dr. Riccardo Manzin. ${ }^{89}$

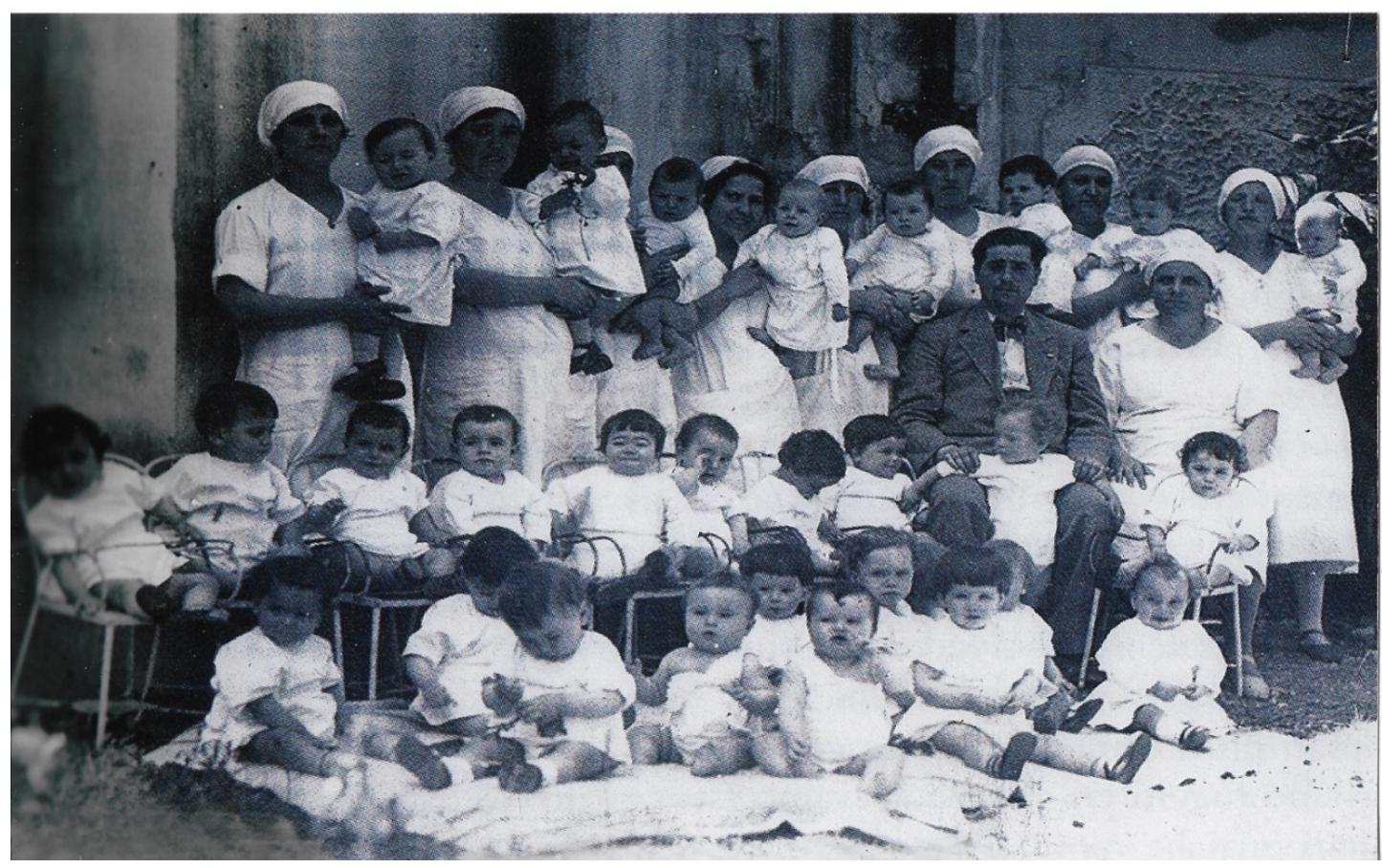

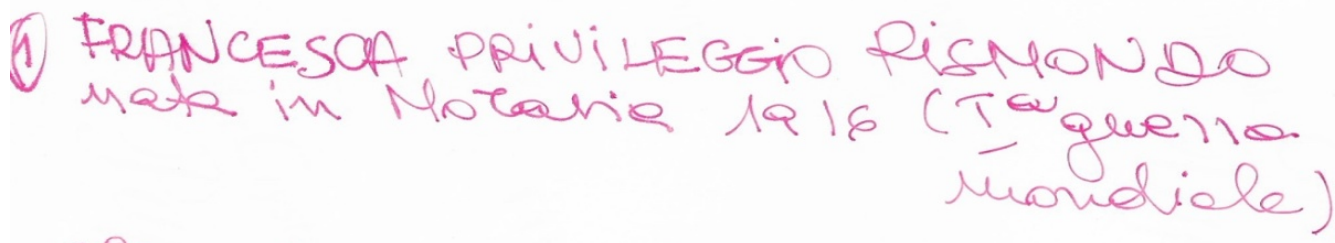

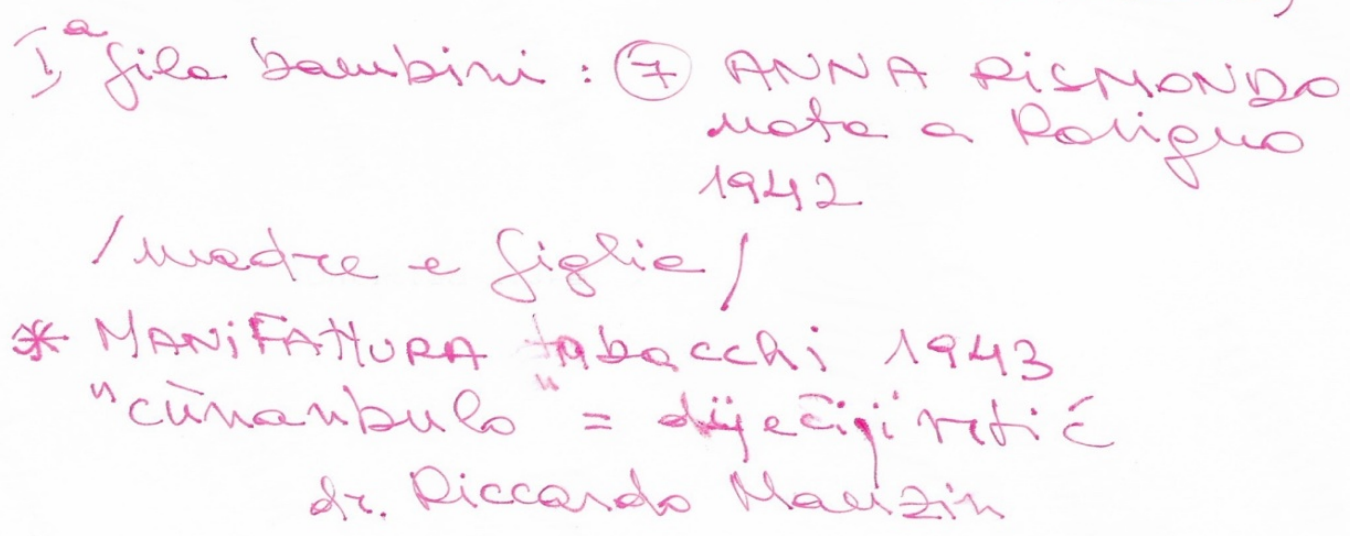

Slika 15 a i b. Cùnanbulo, 1943. godine

\footnotetext{
${ }^{89}$ Prema pisanjima kćerke, Tullie Manzin, Riccardo je bio lokalni liječnik, rođen u Vodnjanu i oženjen za napuljsku učiteljicu Eddu. Život je proveo liječeći Rovinjce, posebno djecu. Radio je, između ostalog, kao liječnik u Tvornici duhana Rovinj i Ampelei (Zuliani 2008: 50-51).
} 
Osim što predstavlja izvrstan izvor za saznavanje o prošlosti, ta fotografija ima i dodatnu vrijednost. Naime, na fotografiji se nalaze kazivačica i njezina majka. Na poleđini kopije fotografije obilježeno je kako mama stoji prva u redu slijeva, a dijete, odnosno Anna, u prvom redu dolje sedma. Kazivačica objašnjava razdvojenost od majke u ovoj specifičnoj situaciji:

Bilo je pitanje časti ne uzeti u naručje svoje dijete (A. R.).

Dakle, da bi dokazale profesionalnost ili, kako će kazivačica reći, čast, one nisu direktno brinule o svojem djetetu, čak i kada su bile dežurne njegovateljice. To se, barem prema dostupnim informacijama, ne odnosi na dojenje vlastitog djeteta.

Uvjeti rada za vrijeme Italije su bili nešto lošiji. Ponovno ćemo posegnuti za kazivanjem koje otvara pitanje politike zapošljavanja. Osjećaj neravnopravnosti i nepravde koji je unesen za vrijeme talijanskog fašizma, snažno je utjecao na intersubjektivne odnose, a poslijeratni period obilježen siromaštvom dodatno je otežavao rad. Ipak, u duhu fašističke obnove, jaslice nastavljaju s radom, a otvara se i Dopolavoro, mjesto u sklopu tvornice s kulturnim i sportskim aktivnostima za radnice.

Dopolavoro je bio jako važan, bilo je puno inicijativa. 1936. zbor je pobijedio na državnom natjecanju u tradicijskim pjesmama i nagrađen je u Rimu. Nagradu je uručio Mussolini (!). Ja imam fotografiju mame koja je tom prigodom s još nekoliko radnica izvela gimnastičku vježbu. (A. R. )

Rad u TDR-u i tada je predstavljao jedini izvor sigurne zarade i stoga je bio jako cijenjen i iščekivan. "Kada bi izašao natječaj, mi bi sve pustile i trčale bi u tvornicu, a kada bi se koja zaposlila onda smo radile feštu" (Nemec 2012: 366). Osim sigurne plaće, kazivačice koje su iskusile rad u pogonu za preradu ribe uvijek će naglašavati da je u tvornici duhana lakše jer radiš na suhom i toplom.

Malo žena je šlo, tamo je bilo suho i čuda laglje. (M. J.)

Da je bilo teško [Kraljevina Italija], ali si morala raditi. Tako si imala kapu, i na kapi i na mantilu si imala broj, znaš. Onda je bija jedan privatnik, neki Talijan, nije bilo pod nama to, i ako si išla u wc 2-3 puta kad si imala menzu [mjesečnicu] onda te gledao, drugi dan nisi došla raditi. (D. C.)

Za vrijeme Jugoslavije, uvjeti rada ostaju gotovo isti. Traka i mehanizacija se uvode tek 1968. godine. Osnovna razlika je u nacionalnoj strukturi radnica. U tvornici 
za preradu ribe se poboljšanje ipak znatnije osjeća. Dotad se u Mirni radilo samo ako je bilo ribe, a sada je, zahvaljujući hladnjačama, ribe bilo uvijek, a žene su dobile fiksno zaposlenje.

Plaća nije nikad kasnila, no nije bila velika. Radnice Mirne d. d. se prisjećaju kako je ta tvornica za preradu ribe kasnih 1960-ih i 1970-ih godina imala bolje poslovne rezultate od TDR-a, međutim, unatoč njihovim molbama da im se povećaju plaće, uprava se nije dala nagovoriti.

Mirna je jako, jako dobro stajala. Je pomagala i fabriki tabaka (TDR) i tu je bio onaj Brečević ili Brajnović, ne znam ko je bio [direktor tvornice], i nam je mogao povećati plaće, ali nije. Da šoldi moraju biti nutra za stare dane. Ma koje stare dane? Povećaj nam sada kada ima. (D. C.)

Plaće su bile redovite kakve da su da su bile, bile su. (M. A. P.)

Kako si normu učinija tako su pisali i si bi plaćen. (M. M.)

Pole sam na kičmu rano obolela. Puno sam bila na bolovanju i po 4 sata radilapri kraju. A ja sam bila uvijek na normu, a onih 4 sata mi je bilo plaćeno, ako san storila normu dobro, ako ne, niš malo si dobila. I zato mi je forši penzija mala jer si morala normu storit a ja san se forcala uvik delati, pole su me takale ruke tvrde, boleti ruke i, kičma. Doktorica mi je sad rekla, pa vi kao da ste u rudniku delala. (M. J.)

Iako su formalni uvjeti rada u smislu plaće, stalnog posla i osmosatnog radnog dana označavali napredak, s druge strane rad s ribom je tada, kao i danas, predstavljao jedan od najneuglednijih poslova.

Vlažno, propuha i svega pomalo. I čuda nas je bilo i svaki ima svoje mišljenje. Teško je, nije lako, ali je takovih ljudi koji se daju na tebe, ponižavati. Ja san ono vajka bila nekako, jer san tako rođena. I onda ja san vajka bila druga, po svuda. $\mathrm{Ni}$ bilo lako ne. Sve skoro na normu smo delale. Šefovi su nan bili muški, a ženske su bile samo kako, su pregledavale, da li u redu delaš ili ne...maeštre. (A. Č.)

U Mirni je bilo dobro, samo ča je bilo jako teško, vajk u mokren. Ja nis bila u proizvodnji ponavljan, ambalaža je bilo jedno, u ribi drugo, ma si vajk zadava [smrdio]. I noge i ruke i svi si bi vajk cili osan ur u vodi, to su žene jako bolesne, ča su tamo delale cili vek. (M.A.P.)

Ja ti rečen da je bilo ružno oni put se sve ručno delalo, kad smo ribu rizali ledenu s frižidera ledenu i si si močija ruke, ledenu ribu si riza a ruke si si močija $u$ toplu vodu. Dobro da nas ne bole ruke. (M. M.) 
Primili su me dobro, bija je šef, bila je, predradnica, maeštra mi smo je zvali. Onda ti je ona pokazivala šta imaš za delat. Radile smo osam sati. Smo počele u šest, do dva. A posle smo i treću smenu delali i subota se delala ako je bilo ulova ribe i u nedelju. Nekad se ostalo preko vremena, nekad se je radilo popodne i celi dan.

Otkad sam ja došla žene su stalno bile zaposlene, a prije toga je bilo većinu kad je bilo ulova su radile a kad ni bilo ulova, nije se radilo. Su ti izabrali koga su preferirali...To je bilo još, na primjer, prije nego sam ja došla. Posle je bilo ribe, tako reć uvek jer je bila hladnjača tako da smo imali uvijek i zimi i liti, ribe. Bila je sardine, sardela, bili su skuše, bija je i inćun ča se solilo... i onda slane se je čistilo i ukutijavalo. Bilo je puno posla. Onda nisi ima strah da ćeš ostati bez posla ako se ponašaš kako treba, kako je bija zakon, e...I kako si poša u tvornicu, poša si i u penziju odonuda. (M. G.)

Na važnost penzije za radnice posebno će se osvrnuti potomkinja prvih tabacchina.

Od toliko pričanja, zaboravila sam na nešto jako važno, a to je penzija. Tabacchine su po završetku radnog staža imale pravo na penziju. To je bilo jako važno i činilo je još jednu odliku tadašnje radnice. Danas nam se to čini normalno, ali u kontekstu društva u kojem poljoprivrednici i ribari nisu imali nikakvu pomoć ili dodatke, starost je vrlo često značila siromaštvo do smrti ili ovisnost o milosti institucija. Tabacchina se sama spašavala takve sudbine, a često je pomagala cijelu obitelj. I danas se u nekim društvima osjeća teret najstarijih građana, ali naravno u manjoj mjeri. (A. R.)

Svaka je radnica, ovisno o vlastitom iskustvu premreženom $\mathrm{s}$ drugim životnim okolnostima, reflektirala specifičnu poziciju i odnos prema radničkom iskustvu. Za razliku od tabacchina koje su imale jaslice u sklopu tvorničkog pogona, žene iz Mirne su djecu ostavljale na drugom dijelu grada. Uz to, kazivačice se prisjećaju koliko su bile nezaštićene kao trudnice, dakako ovisno o poziciji na kojoj su radile.

Brečević [šef određenog postrojenja] nas je čini nosit. Kamen ča smo slagale smo morale dizat, mi žene, to nas je čini delat... to je bilo lijepo? I ti važ od 10 kila nosit a ja bila u drugen stanju i to si mora delat misec i po prije poroda i si se torna [vratila si se] misec i po pokle. Jedino ti vrtić nas je spašava. (M. J.)

Prisjećaju se tako smjena koje su trajale do ponoći. "Nikakova plaća, a delali smo i po 16 ur. Draga moja, kad smo imale delati do pol noći vajka, kad bi bilo ribe, smo delale samo z ribon, pole smo i čistile kutije i ča je trebalo, a vajk u sklopu dela", reći će kazivačica (A. P.) koja je sa sedamnaest godina 1948. započela rad u Mirni. Ali jedna od najgorih uspomena je ona na rad na hladnom i mokrom.

A tamo di san ja bila su bili teški uvjeti rada, ja san bila kod Brečevića [šef]. Ovako, mi smo solile barillice [bačvice] od drva. Tako 8 sati san stala. Od drva 
su bile i smo ih prale u sodi kaustiki [sumpornoj kiselini] i tu smo slagale ribu. Tako dvije su se dele naspro [glave su se slagale nasuprot]. Jedna je davala kašete i to si morala delat kako luda. Jedna kad bi finila, su bile na normu, druga je vikala, dojdi mi daj mi ribe. To vrije, to je sve pekla voda po nas i gulile smo pak to smo solile u važe. To smo na banak [klupa/stol], smo sve jednako delale. Kod Brečevića ča smo delale smo delale sve isto. To je bila baraka velika puli tega Brečevića, tu je bia i propuh i sve i tako noge na betonu i voda ispod jer tamo su bile velike vaške [kade] i voda u njima, kad je bila posoljena riba i povrće pa tu su vadili van pa je voda tekla sve pod nami pod nogi, tu smo morale nad tim delati. Kad je došlo to povrće smo gulile te malanzane s ruki prsti. To nas je sve bolo. Pa smo morale rezati to sve na ruke, nismo imale mašine. Svi prsti, sve ruke zrežene. Ma jako uvjeti teški rada; kad van rečen da puli njega nan je bilo tako teško. I pole su me dali u salon. Tamo san samo, na mašinu je tekla srdela i smo stavljale u kutije, limenke one ča se prodaju. Tamo san to delala, tamo mi je bilo puno lakše jer san bila u suhem i teplem (M. J.).

Dinamika posljednjeg kazivanja (posebno u audio formi) vjerno nam predočava dinamiku rada. Možemo vizualizirati djevojke koje velikom brzinom prenose kante, polijevaju vruću vodu, pažljivo slažu ribu. "Stahanovizam se od samog početka svojeg postojanja, dakle još 1935., definirao kao novi polet socijalističkog takmičenja" (Matošević 2015: 71). Međutim, usporedimo li godine nastanka tog pokreta $\mathrm{s}$ dostizanjem visoke produktivnosti $\mathrm{u}$ istom periodu $\mathrm{u}$ Rovinju, dakle $\mathrm{u}$ vrijeme Kraljevine Italije, vidjet ćemo da se i tada radi udarnički, jer je to bio uvjet zaposlenja. Nije se svatko mogao zaposliti u Tvornici duhana, konkurencija je bila velika, pa su djevojke prolazile rigorozne testove prije zasnivanja radnog odnosa. Kazivanje o liječnikom pregledu otvara novu perspektivu o selekciji radnica. Opisujući kako su im kontrolirali oči ne bi li utvrdili da djevojke nisu razroke i ruke koje su morale biti "skroz fine”, dakako bez znakova artritisa, kazivačica navodi da su se tih, za Rovinj još predratnih godina, dakle 1939. i 1940. godine, u Tvornici duhana sve više zapošljavale slavenske djevojke, posebno iz Rovinjskog Sela (Nemec 2012: 366). Je li to značilo da su fizičke predispozicije, koje su tvornici imale donijeti profit, sada postale važnije od podrijetla zaposlenica ili je takva selekcija postojala i ranije, teško je reći. Činjenica da se migracije intenziviraju i prije promjene političkog uređenja koje je moguće favoriziralo Slavenke govori u prilog kapitalističkoj mašineriji koja, u skladu s potrebama i zakonitostima liberalnog tržišta, teži jeftinoj i efikasnoj radnoj snazi bez 
obzira na rodne, etničke ili klasne razlike. Međutim, površno i naivno promišljanje selekcije zaposlenika koja je na površini nediskriminatorna onemogućava nam da iščitamo ono što se iza takve mašinerije zapravo krije; mehanizam produbljivanja razlika pod velom "nevidljive ruke". 90

Iako izvorno sovjetski fenomen (usp. Matošević 2015), udarništvo ${ }^{91}$ se kao mehanizam povećanja produktivnosti može sagledati i u kontekstu kapitalizma, dakle i u kontekstu austrijske uprave. Ranije spomenutim mehanizmima povećanja produktivnosti, kontroli i disciplini, možemo pridodati i treći, koji se temeljio na ideji nagrade. Psihološkom igrom kompetitivnosti, vlasnici su od radnika tražili nemoguće. Kako će kazivačica reći:

Pritisak je bio velik, i kako veliki, jer si stila zaraditi i čim si dela do malo više opet su tražili još više (M. A. P.).

Mene je šef predložio za udarnicu. Bile smo tihe i radile smo svoj posao. (A. S.)

Djevojke su, dakle, radile na normu, ali su redovno nagrađivane one koje su proizvodile najviše. O nagradama nam zorno svjedoči Knjiga radnica, u kojoj je marljiva austrijska uprava bilježila svaku promjenu, a posebno napredak radnica. Dakako, bila je to i čisto administrativna nužda usmjerena na kontrolu financija i dostupnih ljudskih potencijala. Neke su radnice u svom radnom vijeku bile nagrađene i petnaest puta jednokratnim iznosima od po nekoliko kruna. Za vrijeme Italije norma je bila 1200 cigara, međutim ako bi napravile više, taj bi se višak računao kroz, primjerice, slobodne dane (Nemec 2012: 368). Udarništvo kao koncept ima svoje specifikume u mitskim figurama herojskih radnika Stahanova ili Sirotanovića (Matošević 2011, 2015), međutim i austrijski je kapitalizam u svojoj beskrupuloznoj žeđi za profitom, jednako tako, psihološkim manipulacijama povećavao produktivnost svojih postrojenja. Kod

\footnotetext{
${ }^{90}$ Nevidljiva ruka, izraz Adama Smitha kojim je u djelu Bogatstvo naroda označio način djelovanja tržišnih snaga, sugerirajući da se tržištem ne bi trebalo upravljati izvana kako bi se uskladili interesi pojedinaca $i$ društva. Tržišni sudionici, potaknuti međusobnom konkurencijom te odnosima ponude $i$ potražnje, vlastite ciljeve (maksimiziranje profita) usklađuju s ciljevima drugih sudionika i društva u cjelini (enciklopedija.hr).

${ }^{91}$ Udarništvo je sovjetski termin za "super produktivne" radnike, koji je potaknuo visoko produktivan i entuzijastičan rad. Koncept je uveden u socijalističku Jugoslaviju i pretpostavljao je novu metodu rada temeljenu na kompetitivnosti među radnicima (Matošević 2011: 184-211).
} 
tabacchina je to bilo moguće kroz strategiju dostizanja statusa "najbolje od najboljih", čime je prestiž među radnicama rastao, a kućni se budžet punio.

Obične djevojke koje rade u tvornici hodaju uzdignute glave jer imaju sredstva da se dotjeruju, da dobro pripreme miraz zbog čega postaju i poželjne udavače. Iz toga proizlazi i pravo da same biraju partnere i izbjegnu tada uobičajenu praksu ugovorenih brakova (A. R.).

\subsubsection{Borba za radnička prava}

Austrijska je uprava, osiguravala određeni socijalni standard u skladu s tadašnjim međunarodnim zahtjevima za reformama društva. U Rovinju se $u$ to vrijeme tek formirala radnička klasa, pa se prva organizirana grupa socijalista javlja tek 1898. godine sa sjedištem u čitaonici u Ulici Dietro Castello. Rovinjski su socijalisti od 1903. slavili 1. svibanj, a 1906. godine predavanja su održali Angelica Balabanol, Enrico Ferri i Giuseppina Martinuzzi (Džeba 1987: 43-44). Među radnicama su se također izdvajale, kako će kazivačica reći, rivoluzionarie. Godine 1894. su tako ustale protiv dvojezičnih natpisa u Rovinju i Piranu, a između 1919. i 1921. godine sudjelovale su u štrajkovima solidarnosti. Jedna od revolucionarki bit će i teta Giovanna.

Zatvarali su ju svaki 1. maj. Za vrijeme fašizma nije se smjelo i za disciplinsku kaznu su je stavljali da radi u barake, na Centeneru, za kaznu (A. D. Q. i F. Q.).

Giovanna (1906.-1943.) je bila jedna od radnica koje su svoju karijeru tabacchine provele u sklopu nove tvorničke vlasti i uređenja - talijanskog monopola, prema kazivanju, u razdoblju od 1920. do 1943. godine. Na žalost, Giovanna umire mlada i za sobom ostavlja dva sina, polubrata. Njen kratak život, prema jednoj od kazivačica (A. D. Q.) reflektira duh vremena i karakter rovinjskih radnica. Giovanna je bila buntovna, ali vrijedna radnica. Osim u pogonima na rivi, za kaznu je često radila u barakama gdje se sušilo i djelomično sortiralo lišće. Ti su pogoni bili na nekoliko kilometara od njene kuće, tako da i to valja uzeti u obzir kad se mjeri težina kazne. Uz Giovannu, kazivačice napominju da je bilo više žena koje su sudjelovale u demostracijama protiv fašističke uprave. Unatoč tomu, otkaz nisu dobile. Uz težak rad, Giovannin je život obilježila i ljubavna tragedija. Naime, iz ljubavi prema potomku dobrostojeće fašističke obitelji koji je u tvornici radio kao jedan od nadglednika, rodio se vanbračni sin. 
Bilo je puno vanbračne djece u to vrijeme. (T. L.)

Obitelj mladića nije dozvoljavala brak s obzirom na njenu političku aktivnost, pa je odlučila da njen sin neće nikada imati kontakt s ocem. U tome je i uspjela unatoč činjenici što su živjeli u malom gradu gdje se svi poznaju. Giovanna se udala za drugog muškarca kad je njen prvi sin imao 10 godina. Svo to vrijeme ga je sama odgajala uz mukotrpan rad u tvornici. U braku je dobila još jednog sina. Na žalost, Giovanna umire mlada. Braća su razdvojena. Prvi sin konačno upoznaje oca, no njihov zajednički život traje samo 6 mjeseci jer je otac odveden i prema svjedočanstvu kazivačica, ubijen u Pazinu i bačen u foibu (jamu). Kasnije su o tom djetetu brinule tetke. Drugi sin doživljava sličnu sudbinu s obzirom da je Giovannin suprug odveden u Dachau i nikada se nije vratio. Kazivačica koja mi prepričava ove teške sudbine, naglašava da je do njegove smrti 2012. godine bila bliska s jednim od navedenih "dječaka". Ponosna kao Rovinjka i tabacchina naglasit će da joj je često govorio kako ga upravo ona podsjeća na majku.

Ne toliko fizički, nismo bile slične. Nego ta naša anda (taj način bivanja, op. a.).

Radnice pogona za preradu ribe ne pamte veće štrajkove, ali ponavljaju da su pokušavale izvršiti pritisak da im se povećaju plaće. Tek će jedna stidljivo priznati:

Jedan put smo bile u štrajku. Nikoje su htjele nikoje nisu htjele i šefovi su nas tjerali raditi a mi smo rekle ne, tu ćemo biti jer smo se dogovorile da ne gremo delat. Razlog su bile plaće, da nan daju male plaće. Da puno delamo s ton ribon, puno se je prodalo, puno proizvodilo a male plaće. Bile su plaće redovito od meseca do meseca, se ni kasnilo ali male su. (M. J.)

Osim eksplicitnih mehanizama borbe posredstvom štrajka, zanimljivo je skrenuti pažnju na manje očigledne, ali ipak značajne mehanizme kojima su žene osiguravale svoju poziciju u radničkom kolektivu. Primjeri se odnose na obilježavanje katoličkih blagdana. Dok će dvije kazivačice (L. M. i A. D.) koje su radile za vrijeme Italije (i kasnije) naglašavati posebno emotivno i za njih važno iskustvo zaustavljanja strojeva na Veliki petak u 15 sati, jer se vjeruje da je tada Isus preminuo na križu, one kojima su blagdani bili formalno zabranjeni za vrijeme Jugoslavije svoja su prava ostvarivale "ispod radara".

Je bilo puno ribe, čak i jenu Svetu Mariju ča ja znan smo trebali poć delati i nisu pole [išle] sve i su nas tornali na raporat. (A. ̌C.) 
Da, se slavilo, ali kući, ne vani. Dio guai [ni slučajno]. Znam jenu, ona kad je bila kakova fešta bi rekla 'Ja sutra ne dojden, perke je to i to i gotovo'. I ni došla delati je pošla u crikvu. I šefovi su prihvatili. Ona je tako naučila, tako je bilo. Ona je držala do sebe. Sam rekla mojoj sestri, da imam ovu pamet i manje godina bin drugajče gledala. Na prvom mjestu sam ja, na drugom moj muž onda su dica. (D. C.)

Nikoji šefi su nan dali, nikoji nisu. Na primjer za Svetu Fumu [16. rujna] 4 sata san delala pa 4 sata šla doma spremati. To ku ni nedeja. Nisu ni oni svi isti, nikoji je bi dobar, nikoji nisu, oštri jako samo radi, radi! ne daj Bože da sideš. (M. J.)

\subsubsection{Intersubjektivni odnosi}

Dok sam u kontekstu sjećanja govorila uglavnom o tabacchinama, dakle radnicama TDR-a, u redcima posvećenima življenim iskustvima uočit ćemo dominantnije prisustvo sardellina. Već sam u prvom poglavlju ovog rada navela poteškoće prilikom provođenja intervjua te je stoga specifičan uzorak ispitanika rezultat dostupnosti sugovornika. Ispočetka me brinuo takav odnos, međutim činjenica da su osobe iz okolnih sela dolazile su u Rovinj već od kraja 19. stoljeća, no ta se migracija, posebno žena radnica, intenzivirala nakon Drugog svjetskog rata, omogućila je smještanje kazivačica u odnosu na specifični društveno-povijesni kontekst koje su o(ne)mogućavale moj rad. Većina je tabacchina talijanskog podrijetla emigriralo zajedno sa svojim potomcima u Italiju tijekom ili odmah iza 1947. Naravno, bilo je i onih koje su ostale, a neke smo kontaktirali i u Italiji. Iako kazivači nerado govore o tome, određeni antagonizmi su postojali. Tako je jedna kazivačica (L. M.) navela kako je uvijek nastojala da za stolom radi s Rovinjkama. Nije željela sjediti i raditi sa Slavama. I djevojke slavenskog podrijetla potvrdit će isto. Iako su njihova iskustva također raznolika, kroz analizu se iskristalizirao novi potencijalni intersekcijski element, uz gore navedeni nacionalizam: osobni karakter i sposobnost da se svojim znanjem i stavom obrane u svakodnevnim situacijama.

A čuj, bilo je kako kada. Kako kada. Kako si se ti postavija. Ako su videle da si, da si mekan su te malo gazile... A ako si im odgovorija su te puštile na miru. (M. G.). 
I druge će kazivačice naglašavati osobnost pojedine radnice kao ključnu za dostizanje bolje pozicije.

Neke su znale se tiskati, znale govoriti, jene su se više držale, više su male za se to govoriti [znale su se hvaliti] (A. P.).

Da sve nije bilo idealno i da su postojali problemi unutar kolektiva, ne samo među radnicama već i s nadređenima jasno je iz kazivanja:

Mogu reći da je bilo šefova u tvornici koji su koristili tu svoju poziciju, ali bilo je i žena koje bi ih gađale nečime, ali onda bi bile kažnjene na način da ih se stavi na lošiju poziciju, degradirane su bile. A bilo je i onih koje su prihvaćale i tako su gradile karijeru. Muškarci na poziciji, koji su osjećali moć, često su bili nepristojni u tom smislu (M. R.).

Nisu ni oni svi isti, nikoji je bi dobar, nikoji nisu, oštri jako samo radi radi! ne daj bože da sideš ili jedan put na zahod san pošla da izvinete smo žene, menstruaciju, i tekla zamon ona ča piše uri da ča tamo delamo, ja nisam nikad to duperala, pušiti u wc-u (M. J.).

Politike zapošljavanja i gore navedene iskaze možemo usporediti s primjerom koji iznosi Karen Sacks (1975: 227) navodeći u svom primjeru da plemkinje dijele određene privilegije s plemićima koje ih razlikuju od pučanki, ali unutar vladajuće klase bivaju diskriminirane kao subordinirani rod, žene u industriji dijele određene povlastice $\mathrm{s}$ radnicima koje ih dijele od žena koje nisu angažirane u industrijskom radu. Međutim, unutar radničke klase uvijek su subordinirane s obzirom na rod, a iz ovog primjera možemo primijetiti i subordiniranost $\mathrm{u}$ odnosu na nacionalnost. $\mathrm{O}$ stranoj kontroli rada Andrea Matošević će, navodeći svjedočanstva Diodorusa Siculusa (1. st. n. e.) o barbarima kao nadglednicima antičkih robova, ustvrditi da postoje mnogi primjeri dihotomiziranih odnosa radništva i nadglednog osoblja koji kriju strategije implementiranja mehanizama subordinacije s ciljem polučivanja veće produktivnosti sa što manjim ulogom, dodajući da u smislu discipliniranja proizvodnog procesa kroz fiksiranje viška moći uvijek na jednu stranu Michel Foucault vidi rađanje specifičnih modaliteta moći koji mogu funkcionirati u najrazličitijim političkim režimima, aparatima ili institucijama (Matošević 2011: 163-164). 
Pjesma, topla riječ, razumijevanje ili razgovor (v. Hadar 2007) za radnim stolovima često su pomagali djevojkama u prevladavanju stresa, gladi ili (seksualnog) uznemiravanja od strane nadređenih. Radnice za vrijeme Jugoslavije svjedoče i iznimnoj solidarnosti koja je postojala među radnicama i radnicima općenito, često u taj kontekst stavljajući i šefove, koji su im u sjećanju ostali kao pravedni.

Jedan put san došla iz moga sela. Od Rovinja do moga sela je 37 kilometri, jer san sad u nedilju moj sin nas je pelja smo bili u mojen selu. I san rekla molin te zmiri sad, ja san računala digo trideset, malo više od trideset, san tako računala. A jedan bot san došla valje iz mog sela do Šošiće na noge, pedeset i drugega lita. Kurjera mi je pobjegla i drugo nisan imala s kin doć. A san imala strah, san bila frižak radnik, to si drža ko sveto pismo. I došla san na noge, ali ja san zmolila ki zna kolike oče naša za tin mojin šefon. Digo slušajte Poldo, Poldo se je zva, slušajte, ja san, kurjera [autobus] mi je ušla [pobjegao] ja san došla do Šošića na noge, iz Šošića je makinja hodila, vlak. Digo sad ću doj delat. 'Ne' je reka, sad se sidi, prontaj jist, sad ji, hoj doma spat. Drugu šetimanu namisto da budeš slobodna ćeš delat, ćeš ti delat toliko ča si hodila na noge. Vidiš ja mu ne moren zabit nikad drugo, to je bogati koliko lit, '52, alora. (M. A. P.)

U preradi smo bile na normi, $\mathrm{u}$ ambalaži isto na normi, ali mi je bilo lijepo, sam bila mlađa, sam bila kuntenta, smo pjevale, onda smo bile tri-četri od nas ...sve smo škatulivale i zarađivale normu, normu i po. Ona normu i po, ja normu i po, sve tako...onda smo se uhvatile, sam išla u wc, sam išla na pauzu znaš, onda smo pjevale vamo i tamo, nam je bilo lijepo. Po noći u ambalaži kad smo radile smo napravile, mamma...jedna makina da je bila u kvaru druga da ne i ova mašina šta je bila smo radile i smo napravile normu, anke preko. Smo donesli kolač... ona kolač, ja kolač. Je bila neka Magda je radila najbolju pitu. Je bilo dobro. (D. C.) 


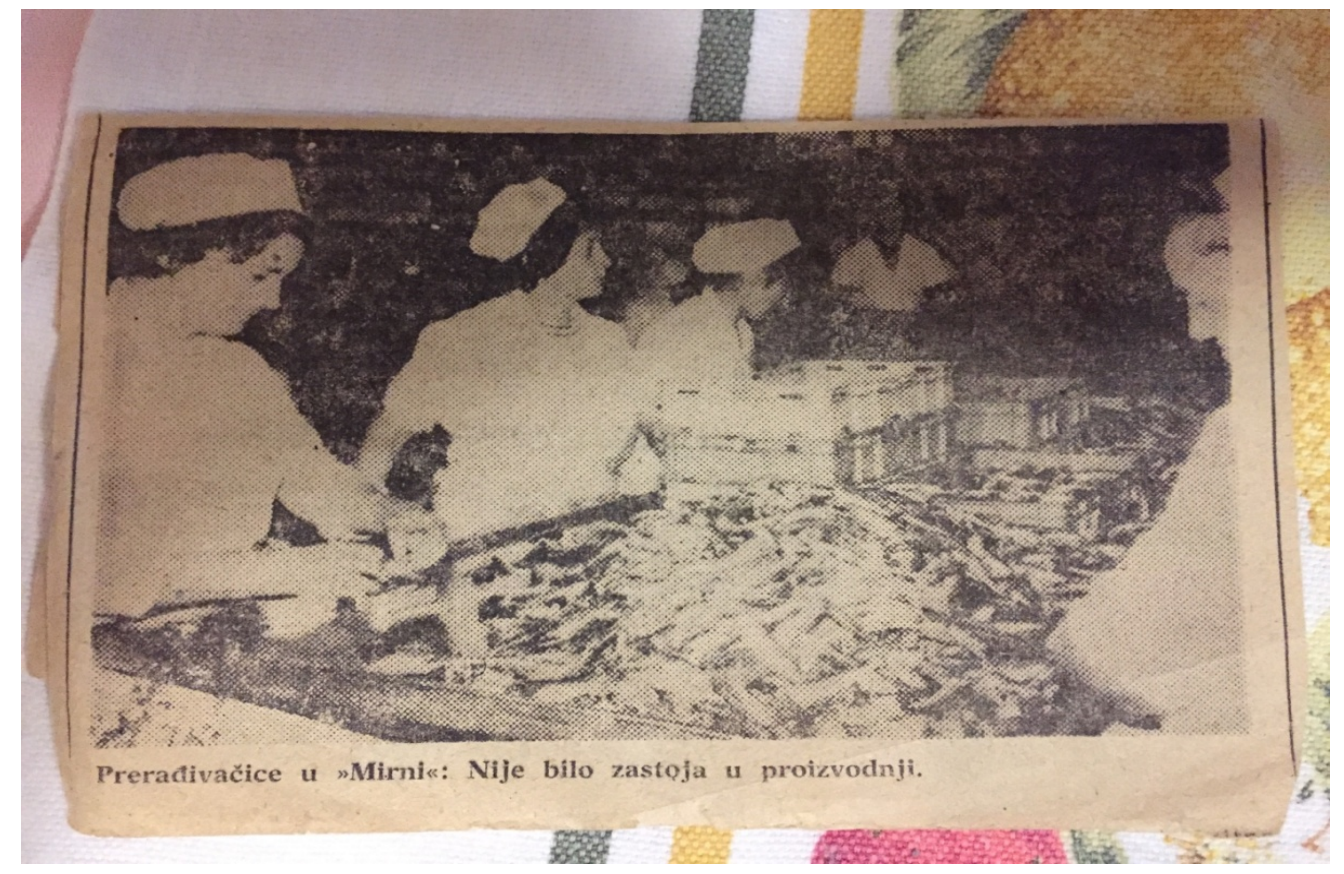

Slika 16. Kazivačica S. V. čuva fotografiju objavljenu u knjizi na kojoj se nalazi zajedno s nekoliko radnica

Želja za integriranjem u novu zajednicu brojne će radnice navesti na učenje talijanskog jezika, čak i za vrijeme Jugoslavije, te prihvaćanje nekih općih obrazaca ponašanja i poštivanja grada koji ih je "prihvatio".

To ću postajat anke dokle je svita, jer čuješ, bez obzira što sam rekla i što je pravo da smo samo smrtnici svi, al ipak onaj iz grada je malo drukčiji nego onaj sa sela. I više, malo više zna jer možda je načitaniji ili više u društvu. Žena sa sela je imala šiće, grablje, vile, tovara i ča je imala kravu, kampanju i doma i dicu i sve, ni imala lazno zet libre. U tome je stvar anka, koja su bile naprednije. Ali tega nemojte zaboravit da ima i danas, neko se puše ja san profesor, ja san medig, ja san ča ja znan ča, mi smo svi nič, eto tako ja to gledan, niko nismo ništa. A tako je bilo i onda, a sad zavisi puno na primjer, ču poć opet od tuda, kad san ja došla u Rovinj ja nisan znala ni beside talijanski, san znala boungiorno, buonasera, grazie, to je bilo sve ča san znala. Ali ja san došla u njihov grad. Tu je bilo mnogo više Talijana prije jer su poumirali ljudi, a dosta hi je pošlo i ća, ja san rekla, ne, ja san došla u njihov grad ja moran naučit, to bi bilo lipo da i oni nauču, oni su jeno malo tvrdi. (M. A. P.)

Uz jezik, kao distinktivna razlika koja je dijelila slavenske žene (dakle, uglavnom one zaposlene u Mirni) od Rovinjki bio je miris ribe, koji ih je pratio i odavao je njihovu poziciju. Kako će Beverly Skeggs u knjizi Formations of Class and Gender (1997) istaknuti, klasno se ponižavanje (među ženama, ne isključivo 
radnicama), između ostalog, temeljilo i na tjelesnim dispozicijama. Edukacija žena radničke klase kretala se unutar puritanskog okvira kućanskog ideala koji je, prema Skeggs, predstavljao širi kontekst pokušaja uspostave srednjoklasne hegemonije u kojoj su prakse nove buržoazije definirane u suprotnosti s ekstravagancijom aristokracije. Razlike su se tako mogle graditi među ženama svih klasa, a one koje su dostizale nametnuti ideal uredne, pristojne i aseksualne domaćice mogle su artikulirati superiornost. Neke od distinktivnih kategorija odnosile su se na ponašanje, odnosno pristojnost, govor i odijevanje (Skeggs 1997: 46). Pozivajući se na Bourdieua, Skeggs će reći kako su tjelesne dispozicije nositelji markera društvene klase, navodeći iskaz kazivačice koja ženu radnicu povezuje sa smradom, neopranom kosom i neurednom djecom (ibid.: 82). U svom recentnijem radu, Skeggs ponovno artikulira tjelesne ili bolje reći vizualno primjetljive kategorije koje izvana nameću (nepoželjni) radnički identitet. To je prije svega manjak dobrog ukusa u odijevanju, glasnoća u ophođenju, jezik koji se koristi, izlazak u grupama (Skeggs 2004: 162).

\subsubsection{Miris duhana i smrad ribe}

Kada mi se jedna od prvih kazivačica požalila kako joj je bilo neugodno nakon napornog radnog dana prolaziti gradom vraćajući se kući upravo zbog smrada koji od nje širio, odlučila sam pitanje smrada ribe, odnosno mirisa duhana postaviti svakoj kazivačici. Iz dolje navedenih kazivanja, jasno je koliko je smrad generiran u određenom industrijskom pogonu stratificirao i razjedinjavao radničku klasu.

A, slabo su nas gledali, znate. To je jako smrdilo, čovjek. Vi ste se mogli oprati i ruke i drugu robu staviti, mi smo imali njihovu robu bijelu, traveršone, ali...(S. V.).

A gledajte mi smo oprale tamo ruke, smo morale se oprati ali riba je jaka, jača od onega sapuna ča smo mi imeli. To ja isto znam kad san šla kući, kad san šla kupit meso za ručak. A ruke van daju od ribe, mi govori (mesar joj se tako obraća, op. a.). Pa sigurno kad san delala $\mathrm{z}$ ribon to san morala još doma prati i roba nan je davala od ribe kako oni ki puše. (M. J.)

Čuj, ispočetka ni bilo baš, ali pokle se navadiš i to je to. Nidan ni reka na oči niš, baren meni... kolike bi mi rekle ti ne zadaješ po Mirni kako da nisi u Mirni, kako ki se je održava (A. P.). 
O načinu održavanja higijene i pokušaju eliminacije smrada najzornije svjedoči iskaz kazivačice D. C.

Nisam čula da su ljudi govorili tako, ali sam osjetila miris pogotovo kad ideš autobusom, a ja sam se prala sa limunom ili s octom. Ocat je jako zdrav za kosu i nokte. I na to se trebalo misliti i gledati nakon rada.

Na neki je način recepcija smrada na razini kazivačica i društva postala metafora za dugogodišnje poniženje i nevidljivost vrijednih radnica Tvornice za preradu ribe. Kako su radnice generalno izostavljane iz javnih spisa u odnosu na muškarce, tako je još jedna nepravda učinjena, ovoga puta radnicama u ribljoj industriji jer su bile prešućene punih sedamdeset godina. Društvo je pamtilo prestižne tabacchine, a nepoželjna pozicija sardellina ostala je u magli stereotipa. Kazivačica M. A .P. zaključit će za sardelline:

Njima je sigurno bilo neugodno, ali onaj ko je osjetio smrad, ku je pametan ni treba, perke žene su si zaslužile kruh da moru živit. A čuješ, ki je jeno malo ima soli u glavi ne bi to nikad činija, ku ne more stat bi poša ća, doviđenja moran poć i gotovo. Ne treba čovika ponižavat perke mi smo svi samo smrtnici,

dok će ona iz Tvornice duhana (M. R.) dodati: "Što se tiče smrada, nemoj misliti da su tabacchine bolje mirisale" (smijeh). Življeno iskustvo kontrapunktirano naizgled banalnoj informaciji o mirisu razotkriva cijeli niz stereotipa koji su repeticijom postali dio kulturnog pamćenja. Dakle, iako su i tabacchine neugodno mirisale (toliko da su neke padale u nesvijest nakon rada na selekciji listova duhana), društvo ih pamti kao dobro odjevene, prestižne radnice. $\mathrm{S}$ druge strane, radnice $\mathrm{u}$ preradi ribe, iako su iznimno vodile brigu o higijeni (pa možda nisu ni zaudarale na Mirnu, kako je jedna kazivačica rekla), u konstruiranom su imaginariju o radnicama zapamćene kroz izraziti smrad.

Čuj, svi smo bili isti. Nismo se ni imali di oprat kako rabi, jer kažem ti, po vodu se hodilo na pjacu, kanalizacije ni bilo, a sve se hitalo u more... Ča se nosilo gori, to se moralo doli, na more i smo bili svi isti. Ča si drugo stija? Opra si se kako si se opra, kako si moga, u nedilju uvečer ili u subotu smo se prale i to je bilo tako i gotovo. Ne da su bile ni Rovinjke čistije od nas, makar su se one držale onako malo više... (M. G.) 


\section{5. 2. Ne-rad}

Koristeći jezičnu negaciju rada umjesto koncepta domaćinstva, želim artikulirati višestoljetnu negaciju kućnog rada kao javno korisnog, de facto rada, kako kod zaposlenih tako i kod nezaposlenih žena. Kako je Silvia Federici naglasila, plaćeni rad je ujedno i javni, odnosno društveno prihvaćeni rad kojim se žena pozicionira u društvu. U skladu s takvim svjetonazorom, nastali su i javni spisi koje smo u ranijim poglavljima analizirali. Zbog negacije kućnog rada, žene su sve do pojave industrijalizacije nevidljive u javnom "povijesnom" životu, a s pojavom industrijskog kapitalizma njihova se subordinirana pozicija ne mijenja, ona samo poprima nove konture. Naglasimo pritom da je u predindustrijskim društvima i većina muških poslova neplaćena. Otvaranjem i preispitivanjem teme kućnog rada kod radnica, istaknut ću njihovu dvostruku opterećenost, ne umanjujući time rad domaćica. Pritom želim naglasiti da neke radnice, djelatnice TDR-a, odnosno potomci TDR-ovih radnica naglašavaju kako su Rovinjke bile uvijek jednake muškarcima. Međutim, na osnovi razgovora, pojedinih reakcija te same činjenice da su zaista radile dva posla, smatram da su takva tumačenja plod onoga što ćemo u narednom poglavlju smjestiti u kontekst kulturnog pamćenja. Mehanizmom selektivnog ponavljanja, radnička iskustva se idealiziraju te se do danas prenosi slika o prestižnim radnicama koje ne samo da donose plaću već i vode kućanstvo, brinu o djeci i suprugu, a nerijetko i o starcima. Često se konstatira da one rade u Tvornici sa zadovoljstvom, jer mogu privrijediti za domaćinstvo. Ostali se poslovi (odnosno ne-rad) ne propituju, oni su, kako je krajem 19. stoljeća Gilman objasnila, prihvaćeni od njih samih kao prirodni i neizbježni.

Žene su uvijek bile iskorištavane kući i tamo [u tvornici]. Kada bi došle kući morale su spremiti večeru, imale su djecu, školu, domaću zadaću, sve (M. R.).

Međutim, paradoksalno, ista kazivačica ne smatra da je položaj žena njihovim ulaskom u tvornicu postao nešto drugačiji od dotadašnjeg. Reći će kako su u Rovinju muškarci i žene uvijek imali podjednak status. Žene su i ranije pomagale, a sada su imale mogućnost dodatno privrijediti.

Muškarci su se, kao na primjer moj otac, bavili uglavnom poljoprivredom i to što su oni ili ribari mogli zaraditi je bilo jako malo. To je uglavnom sve bilo za prehranjivanje obitelji. Nije to kao danas kad idu van daleko s velikim mrežama. Tako da je tvornička plaća bio veliki i važan resurs (M. R.). 


\subsubsection{Majčinstvo i odnosi unutar obitelji}

Jako je važno napomenuti promjene koje su se dogodile na razini društvenih odnosa unutar samo jedne generacije. Žena postaje noseća kolona obitelji ukidajući dotadašnju ovisnost o muškarcu kao glavi obitelji. To osamostaljenje je dakako imalo i određene granice koje reflektiraju tadašnje društvo u cijelosti, ali promjene su ipak bile značajne. Tabacchine su bile tražene udavače i mogle su birati supružnika što je smanjilo dogovorene brakove koji su bili plod roditeljske odluke i nužnosti da se ženska djeca zbrinu na vrijeme. Smanjio se i broj zadružnih obitelji pa više nije bilo uobičajeno da nekoliko generacija živi zajedno u mali stanovima kakvi su rovinjski. (A. R.)

Svaki kazivač i kazivačica će bez iznimke navoditi da su žene imale jednak status u društvu kao i muškarci. Ti su odgovori vezani uz moje pitanje o načinu na koji su muškarci tretirali radnice, odnosno o prihvaćanju činjenice da žena radi u javnoj sferi rada, zatim o načinu podjele imovine i donošenju odluka na razini domaćinstva. Iz svih kazivanja je razvidno da su žene, kako radnice tako i kućanice, imale zavidnu razinu samostalnosti, ne samo u vođenju kućanstva već i u mogućnosti obrazovanja, korištenja slobodnog vremena i upravljanja imovinom. Razina slobode nije ograničavana patrijarhalnim silnicama, već onim ekonomskim. Bogatije žene, primjerice radnice udane za poljoprivrednike koji su posjedovali puno zemlje, su uvijek imale više mogućnosti od onih čiji su supružnici radili kao ribari ili fakini u tvorničkim pogonima. Njihova je plaća bila dostatna samo za osnovne troškove. Da su muškarci priželjkivali ženidbu s tabacchinom potvrdile su brojne kazivačice. S druge strane, kao urbana legenda se širi priča da su tabacchine bile toliko imućne da su one partnere nalazile $u$ stranim financijerima i vojnicima. Iz konkretnih življenih iskustava koje su mi radnice prenijele, mogu zaključiti da se većina brakova ipak sklapala iz ljubavi, da su česti miješani brakovi, ali da ne postoje fiksirani uzorci takvih brakova. Slavenke (radnice TDR-a i Mirne podjednako) su se udavale za Rovinjce i Slavene iz Rovinjskog Sela ili Kanfanara, dakle mjesta koji su gravitirali Rovinju. Udavale su se kako za ribare tako i poljoprivrednike i obrtnike. Isto vrijedi za Talijanke. Među kazivačicama i njihovim precima rijetke su one koje su otišle u Pulu ili Trst za supružnikom financijerom, iako ih ima, ali su zaista brojne one talijanskog podrijetla koje su mlade emigrirale 1947. još neudane ili one koje su ostale neudane.

I muž je gleda, čovjek je gleda koja je bila tabakina da je ipak znači bit mjesečna plaća i tako dalje. To se je i gledalo. Danas, ja jako san stara, ja ne bin čovika 
uzela ko ima sve šolde od svita ko ga ne volin. Ali bilo je tega ki se je, a i danas ima neki slučaj ki gleda da bi preživjeli kako, žena ko ima muž plaću ili muž ako je žena bolje stoji. A čuj to jedno s drugim pole gre napred.

A da su ostajale samo žene, je to bilo često, da su bile same i da je bilo anke vanbračnih djece... na primjer ću opet poj na bolnicu, jer moran jer tamo mi je najboje poznato. Bilo nas je puno žena i sve mlado, sve divojke, i slušaj ti nekemu moraš verovat, a ovaj tovar pa te lipo prevari pa ti je lipo i tako ti stane to dite. Moraš ga zgojit, je bilo u bolnici dosta. Su mogli pensat prije. Zato žena vajk više podnaša nego muški. Se ne reče za niš, žena drži tri kantuna od hiže i četrtega još pomore. ... a ima slučajeva anke obrnjeno, je i tega da. Ali ko žena ne valja onda žena mora vajka stiskat, vajka moraš, ko ne ne gre. (M. A. P.)

Mješoviti brakovi su bili brojni i nosili su sa sobom cijeli niz odnosa koji se zadržavaju do danas. U Mapping the Margins Crenshaw navodi kako su crnkinje višestruko opterećene, i to siromaštvom, obavezama prema djeci i nedostatkom vještina potrebnih za rad. Djevojke koje su s vremenom sve češće dolazile u Rovinj jednako su se tako suočavale s višestrukim opterećenjem. Prije svega im je nedostajala obiteljska podrška. Muškaraca nije bilo, ili su bili na moru ili u polju, a priče koje su mi kazivačice ispričale obiluju razvodima. Žene su radile, a djeca su, ako ih nisu čuvale bake ili susjede, bila prepuštena sama sebi. Posebno je bilo teško onima koje su dolazile u Rovinj, jer nisu imale socijalnu mrežu koja ih je mogla podržavati u svakodnevnim teškoćama. Gotovo je isto bilo djevojkama koje su se udale za Rovinjce i to u najčešćem slučaju zbog odnosa sa svekrvom i zaovama. Iako u istoj državi, udaljene dotad svega nekoliko kilometara od svojeg rodnog mjesta i svoje obitelji, život u Rovinju ponekad im se činio potpuno stranim.

Teško, znaš da je, ne znaš jezik, sam si... Ti Rovinjci, oni su posebni ljudi, oni su sami svoji. I ča da ti rečen, san provala svačega, samo umrit još (M. M.).

U Rovinju ih, sve do 1950-ih godina kada je djevojkama osiguran i smještaj, najčešće ugošćavaju obiteljski prijatelji, rodbina ili kumovi. Takvi društveni odnosi temelje se gotovo isključivo na usluzi smještaja i nemaju doticaja $\mathrm{s}$ odnosima $\mathrm{u}$ tvornicama. Primjeri iz matične knjige vjenčanih ukazuju na to da su djevojke bile zaposlene na dan udaje, što znači da su u Rovinj došle ranije, vjerojatno poslom, a boravkom u Rovinju su stjecale poznanstva i razvijale ljubavne odnose.

Tata se oženio za mamu 1932. godine i tu se otvorio cijeli niz priča jer je mama dolazila iz slavenskog svijeta i odmah je došla u sukob s tim "ludim Rovinjkama" [njegovim sestrama]. Naime, obitelj je bila dobrostojeća; 
posjedovali su kuće, polja, šume koje su bile posebno važne. (...) a naša mama, iako je bila iz 1910. [rođena], ona nas je odgajala vrlo liberalno. (F.Q.)

Stavovi o miješanim brakovima se razilaze kod kazivačica. Primjerice, kazivačica talijanskog podrijetla koja u obitelji nije imala direktnih doticaja sa slavenskim ženama iako joj je kasnije svekar bio upravo slavenskog podrijetla reći će:

Rovinjci tog vremena, na primjer ribari ili fakini nakon Esoda, ${ }^{92}$ su ostali bez žena jer su one otišle [moguće u talijanske tvornice], a oni koji nisu mogli otići nisu ni nalazili ženu. I onda su dolazile djevojke sa sela i oni su ih ženili. Sad, da li je bilo ljubavi ili nije, imali su djecu i išli su naprijed, ne kao danas kad se svi rastavljaju. Ali bio je zaista ogroman priljev slavenskih žena (...) I mogu ti reći da te žene koje su dolazile da bi se udale, one su se s vremenom postale toliko bahate da je uskoro muškarac postao jadan i potlačen. Bile su sposobne (M. R.).

Kazivačica smatra da su one prije svega dolazile da bi se udale. No nijedna od intervjuiranih slavenskih žena nije došla u Rovinj radi udaje, odnosno to im nije bio prvi motiv. Svaka je najprije spominjala zaposlenje i mogućnost stjecanja vlastitog novca. Tako će kazivačica, pridošlica iz obližnjeg sela koja je u Rovinj došla sa šesnaest godina, dati iskaz sasvim suprotan kazivanju rovinjske Talijanke:

Mi, te ča smo dolazile tako, mi smo se poženile sve za Rovinjce, a Rovinjke sve za... za mornare, za militare... I onda su oni ostali tu... tu u Rovinju je bila isto kasarna i na turnu gore kod Svete Fume, tu je bila straža, su bili mornari.

Zašto se nisu udavale za Rovinjce? Jer su bili peškaduri [ribari]? Ili Rovinjci nisu htjeli za njih?

To je bilo (smijeh)... E sad, bilo je ki su Rovinjci oženjeni za Rovinjku, bilo ih je. To je bilo većinom kampanjoli [poljoprivrednici], a onda kad smo došle mi izvana, valda su volili više nas. Ča ja znam. (M. G.)

Mama je provela 66 godina u Rovinju. Ona se ponosila time, svojom obitelji, nama kćerkama, ali mi to moramo reći... ona se uvijek smatrala jednu stepenicu višom od Rovinjki. (A. D. Q.)

Ona ih je vidjela lošijima, nesposobnijima - škarte (F. Q.).

Ja mislim da nije to, one jesu sposobne, ali one imaju karakter usmjeren samo na sebe. Prava Rovinjka, to sam nedavno čula, je baka koju ne zanima njen

\footnotetext{
${ }^{92}$ Iseljenje autohtonog talijanskog stanovništva po pripajanju Istre Jugoslaviji, 1947. godine.
} 
unuk. One neće pomoći u odgoju unučadi. Ništa. Možda neka, ali rijetko (A. D. Q.).

Naizgled idilične odnose unutar prosperitetnog industrijskog grada, narušavali su problemi unutar obitelji uzrokovani nacionalnom netrpeljivošću kada su u pitanju mješoviti brakovi i problemi s alkoholom. Iako većina kazivačica smatra da iako su muškarci pili, nasilja u obitelji nije bilo, barem ne u značajnijoj mjeri. Iz dostupnih kazivanja i iz onoga što sam slušala kroz cijeli period istraživanja moguće je iščitati opterećenja koja su takve situacije ipak izazivale unutar obitelji.

Uvijek postoji određeni broj muškaraca, baš alkoholičara, stupanj više od onih povremenih pijanstava koja su bila uobičajena. Ali takva osoba je bila u ozbiljnoj opasnosti da bude otjerana iz kuće i to uz podršku i odobrenje cijele zajednice. (A. R.)

Kako smo primijetili iz iskustva kazivačice D. C., žene su mogle napustiti muževe, a iz posljednjeg kazivanja potvrđeno je da su žene u tim slučajevima uživale i potporu zajednice.

Zanimljivo je da su na uzorku od devetnaest kazivačica četiri bile samohrane majke. Tri od njih su se preudale, jedna za Rovinjca druga dvije za Seljana [osoba iz Rovinjskog Sela]. Također iz priča o majkama, bakama i tetkama, a što se dalo primijetiti i u kazivanjima u dijelu o radničkim pravima, moguće je uočiti slobodu koju žene imaju u odgoju vlastite djece čak i do mjere da nisu dozvoljavale ocu da upozna sina.

Moj muž je bija pekar i mi smo se upoznali ... oni su stavali na prvom spratu, a ja sam na drugom. I tu smo se upoznali. Ma, ti pokojni moj muž, on je ima stan ima jedan stan, on je bija već uženjen pa se bija rastavija i tu smo se mi upoznali, u staren gradu, kako san ti rekla, u istoj zgradi smo stavali, a ja međutim san imala dečka i smo dosta skupa hodili onda i san ustala trudna. Ja san imela tega malega i ja govorin ten mojen mužu pekaru: 'Znaš ča? Ja iman tega malega, ja malega neću puštiti i ni za ne znan zašto' i san rekla 'Ti si najdi jednu slobodnu ženu, najdi si ti jednu slobodnu ženu meni neće biti krivo.' 'Ma ne' je reka, 'Ča, zašto da ja, ne ne ne ne je reka.' I taj put smo se bili anke uženili i pole san bila mala jenega sina šezdesete godine a je umra mali, mali je umra je ima ništo na pupku mu je ništo bilo, oniput nisu bili doktori kako triba, nisu, da nema spasa i bija je umra, četiri godine mi se čini da je ima. Zaboraviš, perke to je jako dugo. (M. M.) 
Tu san se oženila u Rovinju, Seljan je bia. Ja san stala u Trevisolu, znate kadi je Mali raj, na broju 40. Deset godina. Ja san imala po prven mužu dijete i on je umra mlad. I ta mali moj je ime 2 godine kad san se ja vjenčala za drugega. On je bia stareji mladić, slobodan i ja san ga uzela. A san da neću i san ga odbila i sve... ali san se predomislila... i bolje da san, iman danas njigovu penziju. (M. J.)

Mama je bila u braku. Moj tata je bio jako dobar ali je volio malo popiti. Kad je ima šoldi je popia. Svima je platio piće a fuma je kako turko. I ja ima 66 godina kad je umro. Ona nas je sama zgojila, njega je pustila, je pošla čja. (D. C.)

Je bi iz Rovinjskega Sela, smo se rastavili čuda lit, mala mi je imala 3 lita niti, i san stala sama sa malicom, i tako...Imala san više teškoće radi male, i više dela $i$ više svega. (A. Č.)

Osim što su vanbračna djeca i rastave braka bile dio svakodnevice, pojedine nam kazivačice ističu i liberalni kućni odgoj. Tako se jedna od kazivačica koja ostaje neudana uz smjeh prisjeća riječi njene mame:

Ja sam imala određene poteškoće, tako, ne baš lijepa iskustva. Meni je mama [rođena 1910. godine] uvijek govorila: 'Napravi si dijete. Ostat ćeš sama' a ja sam joj odgovarala 'Zar tako, na cesti?' (A. D. Q.)

Kada je u pitanju broj djece, od pedesetih godina obitelji su sve manje. Isto možemo pripisati sve slabijim odnosima unutar obitelji i nedostatku podrške kod čuvanja djece. Iako vrtići i jaslice postoje, rad istih nije uvijek bio usklađen s potrebama radnica jer su pojedine radile i popodnevnu smjenu, prekovremeno, a bilo je trenutaka kada se radilo i subotom i nedjeljom. Zbog toga su se nerijetko žene odlučivale na manji broj djece. Primjer radnice koja je imala sedmoro djece s većinom rođenih po Drugom svjetskom ratu je iznimka.

Ja kad se '55 rodil, moj sin, ja ga nis imala kamo vrć. Zašto? Bolnica je imala svoje vrtić, su bile vrtić i jasle sve skupa, kad si poša delat dokle je dite pošlo u školu, i san anka delala i tamo, kuhala i to. E alora, '55 lita, ja san delala dvokratno, jer oni put san ja pošla na dječji odjel ki san hodila prvo u školu. Alora kad je moj mali se rodija u osmen misecu '55 nisan imala kamo, si mora poj delat. Misec i po si bija doma, misec i po prije poroda, misec i po pokle poroda. Misec i po kad je malo dite si poša četiri ure delat do šest miseci i to je vrlo malo i vrlo teško je to bilo ku nisi ima nekog svoga da ti pričuva. I kad je šest miseci osan ur, a onda se je delalo dvokratno. Po ure prije nego san ja finila delat se zatvara vrtić, govorin za onega u bolnici. I sad kamo ćeš to dite to po ure? I misec dan san nosila ga u naručju valje u bolnicu i nazad. Je bilo vrlo teško ki je ima dicu. I onda kad san pošla delat nisan imala ga kamo i to kamo da ga nosin i misec dan od šest miseci je bi na dječjen odeljenju u bolnici. Jenu bot 
onako mali mi se zrotola [revrnuo] s posteje [kreveta] i je pa. U špečeri [vitrine s ogledalom] su bili piškoti, je jeo piškoti, oko šest i pol miseca je mora imat, mogo se ubit, zaguštit, ča ćeš, vrlo je bilo teško. A moj muž je bija zidar, na Aldo Rismondo. Onda su hodili u Pulu, u Žminj kamo god je rabilo, u Pazin zidari delati. Tako da on bi poša ća u ponediljak i bi doša u subotu. Ja san bila sama i bilo je jako teško. Zato ja iman samo njega, samo zbog toga što ga nis imala kamo. Inače bolje je imat baren dvoje, zbog samih njih. Po mojoj glavi ja iman samo njega. (M. A. P.)

Ki ima jedno, dva, tri najviše...

Je bia vrtić, jaslice, tu kadi je sada knjižnica [pedesete godine 20. st.]. Tvoja mama je pošla kad je imala misec i po, onda nije bilo to da se bilo doma. Si bija tri miseci doma, misec i po prije i misec i po posli. Jako su bile dobre. Koliko puta su mi dale mlika za malu da ponesen doma...(M. G.)

Familija je bila, imali smo malo i kampanje, delali smo u fabriki. Bilo je teško. I djecu smo imali. Ja nisam odmah pošla delati, izgubila sam 5 godina jer sam imala dvoje djece i nije ih imao ko čuvati pa sam ostala kući i počela sam raditi '61. u Mirni i sam radila do 1983. kad sam išla u penziju. (S. V.)

Ona nas [sedmoro djece] je sama zgojila, njega je pustila, je pošla čja. Bili smo jako siromašni, ja sam morala čekati da ti pojedeš, da se opere pjat i žlica i pirun i da mogu ja jesti. Ja sam u krevetu čekala da se roba osuši [imala je samo jedan komplet odjeće], onda kad bi se osušila sam mogla vani...

Moja mama nas je zgojila, je radila u fabriki [najprije u Mirni pa TDR], je imala biciklu, je išla s biciklom u tuđu kampanju, je pošla delati da bi zaradila kilo krumpira za nas za dicu i delala vamo tamo. Puno je radila, ali nikad nije vikala na nas ili da je rekla 'Dica moja meni je teško'- nikad.

Cijelu noć je znala na ruke rasplesti rukave i opet splesti da drugi dan mi imamo za školu. Onda je i šivala kako makina. Ne biš bia reka da je na ruke napravljeno.

Onda je vidila jedna krojačica da moja mama tako šije i joj je počela davati malo veće komade.

Ja sam rođena od 6 miseci i nisam mogla ništa, sve su moje sestre radile.

Moj brat blizanac je bio samo $300 \mathrm{~g}$, a drugi moj pokojni brat šta ime nosim nikad nije bio bolestan i jedan dan nije mogo disati i u Balama je pukla guma, $u$ Puli su opet čekali i je bia jedan doktor stažista 'Ja bi vam spasio sina ali ne smijem ja da idem nešto napraviti' i tako... a zadnje riječi od moga pokojnog brata su bile 'Mama nemoj plakati'- dijete je umrlo mojoj mami na rukama...Onda je došla jedna doktorica, mojoj mami je bilo stalno slabo nakon toga; joj je rekla idite u Pulu ćemo vam dati infuziju...evo je 97 godina šije i plete, sve bez očala.

A čuvala nas je neka pokojna teta F. M., ona je bila na broju 2 a mi na broju 4. Nekad su djeca bila i sama, prepušteni sami sebi, na ulici. Su čekali da mama ili neko dođe. Je bilo teško, ni bilo lako. (D. C.) 
Iako čista slučajnost, $\mathrm{u}$ našem se istraživanju ističu obitelji s mnogobrojnom ženskom djecom. Kazivačica ističe da nitko na to nije gledao s prijekorom ili da se posebno slavilo rođenje sina.

Ma ne, ne, ne...A zašto? Ča je došlo, to je došlo. To ja nisam nikad osjetila. Sam imala dvi kćere, e. Nikad to se ni brojilo ni ti imaš kćere, on ima to, on ima ono... (M. G.)

\subsubsection{Slobodno vrijeme}

Priče kojima svjedočimo daleko su od idealnog društvenog pamćenja koje se perpetuira tijekom cijelog stoljeća u kojem tabacchine uživaju u šetnjama i odlascima u kino. Tome su zasigurno pridonijele sportske i kulturne aktivnosti koje su se organizirale u sklopu radničkih organizacija, ali koje također nisu bile svima dostupne. Čak i one koje su imale slobodnog vremena, morale su voditi brigu o troškovima.

Znam da su moje tete, ne možda uvijek, jer je to koštalo, ali ponekad su odlazile, ako je bio kakav dobar film, djevojke bi se dogovorile i otišle bi u Kino Rim. S prvim simpatijama su odlazile i na ples, ali nije toga bilo puno. Nalazili bi se na primjer na Punta Corrente za 1. maj, tu su se zabavljali, plesali... (M. R.)

Kao kontrapunkt ovom kazivanju navest ćemo sjećanje kazivača koji odaje uvjete u kojima je živjela velika većina radnica.

Ali nisu sve žene imale slobodno vrijeme. Moja mama nakon što se udala za poljoprivrednika, on je bio iz Rovinjskog Sela i imao je mali komad zemlje blizu Valalte, moja mama je odlazila pješice $[4 \mathrm{~km}]$ nakon završenog rada $\mathrm{u}$ tvornici. A tata je radio i u rudniku, tako da je i on po završetku posla odlazio u polje i radili su zajedno (S. R.).

Draga moja, kad smo imale delati do pol noći vajka, kad bimo bile? Smo delale samo z ribon, pole smo i čistile kutije i ča je trebalo, a vajk u sklopu dela. (A. C.)

Intersekcijski promatrana prva situacija ukazat će na gotovo jednak radnički status muškarca i žene. Dodat ćemo k tome i izjavu kazivača da nije bilo problema u njihovu braku i da je odnos muškarca prema ženi zaista ovisio o karakteru, a ne o tome je li bio Talijan iz Rovinja ili Slaven/Hrvat iz, primjerice, Rovinjskog Sela. S druge 
strane, imućnije su djevojke mogle uživati veću slobodu od onih opterećenih egzistencijalnim problemima.

Osim ove generalne podjele na one koje su nešto imućnije i slobodne djevojke u mogućnosti slobodno vrijeme provoditi družeći se i one koje slobodno vrijeme koriste da bi nastavile rad s ciljem prehranjivanja obitelji, kazivačice nam nude cijeli dijapazon načina i mogućnosti provođenja slobodnog vremena ukazujući na heterogena radnička iskustva i u kontekstu dokolice. Nijedna ne spominje da je imala bilo kakvu zabranu, ali je ponekad bilo posljedica.

Jednom sam išla na krempitu s prijateljicama nakon posla i su me vidile tete, nonetove sestre i odmah su mu išle ispričati još dok ja nisam ni stigla kući, ali ja sam mu odgovorila neka one pogledaju di su bile. Tako, nisam se dala na sebe, nikad. (M. G.)

Ja san se družila svima iz fabrike. Ja nisan nikad imala neku, kolegice smo, ti povidaš [ispričaš] meni ja povidan...to ne treba, jer kad tad nešto pukne. E, prijatelji sa svima i lijepo je meni bilo, vajk. Vajk san bila u pjevačkom zboru, za plesat tuta forca. Najprije je Bolnica imala svoj zbor ali ja od kad san počela $u$ školu san bila vajk u zboru ... 35 lit... i u gradsken zboru, sad nisan nigdi ko ne u našen [zbor Doma za odrasle]...(M. A. P.)

E zbor je bija samo ča ja nisan... Pošla san jedan put, ali ja glasa nisan imala... ja nisan to... Ja sam volila biti slobodna. Ja san se već bila u Pazinu navikla na drugi život. Tamo smo... Lipo nam je bilo, mlade smo bile sve i tako...

Ja sam igrala rukomet. 15 godina. Sam bila u Zagrebu. Zagreb me stio uzeti moja mama me ni stila dat. Si morala slušati mamu.

Ali, mi je bilo lijepo znaš je bilo za plesati za izaći [kasnih 1960-ih], Valaltalta, Lanterna...Kamp Beograd, Valdeliso, Monte Mulini, Škaraba, Kuglana...Živa muzika i disko, Hotel Park...Onda smo bili na Balotu smo igrali penitenza [kažnjavanje] onda ti se moraš skinuti se moraš kupati. A su bili Beograđani i Zagrepčani. Iz Beograda djeca, muški kad si pošla vani oni su plaćali znaš, a Zagrepčani ne, oni su bili kako Austrijanci, pola-pola. (D. C.)

\subsubsection{Emancipacija}

Možemo reći da je u Rovinju opće poznata činjenica da je rad u tvornici (posebno duhana) uvjetovao emancipaciju žena. Iako i ranije uživa relativno povoljan položaj u obitelji s mogućnošću zarade ona postaje noseći stup obitelji i društva u cijelosti. Takvo se mišljenje ponavlja kroz rad i dokazuje kazivanjima radnica i potomaka radnica. 
Novčani prihod ili imovina je prvi i apsolutni uvjet za emancipaciju, bez sumnje i diskusije. Svijest o vlastitom dostojanstvu i vlastitih prava kao autonomne osobe generira se apsolutno s prestankom ekonomske ovisnosti što je i do prije nekoliko desetljeća bila realnost za većinu žena. (A. R.)

Kritičkim sagledavanjem različitih kazivanja, uočili smo da je ta pozicija zaista realizirana, ali je žene dovela do još većih tereta u smislu tvorničkog rada, rada u kući, vrlo često i na polju. Naglašavajući ravnopravnost s muškarcima, kazivači/ce govore o ravnopravnoj mogućnosti plaćenog rada, međutim kućni poslovi se ne dijele, oni se pripisuju ženi, ali se i dalje očekuje da žena, ukoliko je potrebno radi i u polju.

Iako mehanizam društvenog pamćenja sardellina još nije uspostavljen, bar ne u onoj mjeri u kojoj je isto za tabacchine. One nemaju povijesne fotografije koje sežu u 19. stoljeće koje bi dokazale njihovu nadmoć. 'Njihovo vrijeme' započinje $s$ Jugoslavijom i općim narodnim radničkim pokretom. Međutim, osim prividne osnaženosti, životne priče rovinjskih radnica mogu se svrstati uz bok otočkih iskustava koje su Marina Blagaić i Renata Jambrešić Kirin predstavile kroz primjer radnica Jugoplastike, a koja pokazuju da socijalistička modernizacija, unatoč značajnom unapređenju statusa žena, nije uspjela stvoriti uvjete za njihovu potpunu emancipaciju, autonomnu akciju i samorealizaciju (2013: 40).

Plaća je za ženu bila jako važna, miljar posto! E dušo moja ti kad imaš svoje šolde, to su tvoji šoldi. To što su žene mogle raditi to je vrlo važno...bilo je i teško, perke ima takvih [muškaraca] di u hiži [kući] magari ni pomoga niš. Ku je bila oženjena je morala i dicu i na delo i hižu i sve, žena dela vajk dvi žurnade [dnevnice], ne jenu, i tri koj put. To je tako, bez obzira ča žena je vajk brižna [jadna] tako jeno malo zadnja, bez žene di bi bija svit? (M. A. P.)

Fabrike su puno pomogle da se žene osamostale. Teško je bilo, ali si ima svoju familiju, si... To je bija takav život...Nešto si morala raditi. Kad imaš svoje, imaš svoje. Si gazda svojega novčanika, a ne da čekaš da ti ki da mižeriju. (M. G.)

Dobro da smo radile, jer moja sestra danas mi kaže, 'Lako tebi imaš penziju a ja niman ni kunu.' Muž joj daje ali mi reče ja njegovu ne vidin već puti. Meni je drago da san šla delati jer danas ča bin bila kod kuće u selu tamo da san ostala, moreš ne delati, a ča ćeš samo tako ležati i da te mladi okoli tebe, tvoji nevodi gledaju. Ja uvijek kažem da koja more delati da gre delati jer to u starosti dođe dobro. (M. J.) 
Mnoge kazivačice na moje pitanje o utjecaju rada na ravnopravnost odgovaraju ravnodušno, kao da se to podrazumijeva. Istovremeno, jednako tako ravnodušno, prihvaćaju svoju dvostruku opterećenost.

\section{6. ŠTO ROVINJ PAMTI}

La donna Rovignese ga molto carattere ${ }^{93}$ (M. R.).

Kolektivno pamćenje, prema Aleide Assman, možemo podijeliti na društveno i kulturno. Najjednostavnije rečeno, razlika se ogleda u tome što je nosilac društvenog pamćenja pojedinac, trajanje mu je ograničeno na stotinjak godina, ono je međugeneracijsko i ostvaruje se direktnom komunikacijom, dok je za razliku od navedenog, nosilac kulturnog pamćenja materija (predmet ili narativ), ono je neograničeno i transgeneracijsko te se ostvaruje putem simbola u repetitivnim praksama običaja i rituala i materijalizaciji u vidu spomenika i slično. Kulturno pamćenje je ono koje je izgubilo svoje žive relacije i kontekste (Assman 2011: 62), ali i ono koje, kako kaže Jan Assman, "u grupi cirkuliše kao smisao" (Assman 2007: 19). Sjećanja, kojima smo se ranije bavili, smještena su u domenu individualnog, predstavljajući na taj način refleksiju društvenog pamćenja $\mathrm{s}$ obzirom na međugeneracijski dijalog koji je uspostavljen. Pamćenje tretiram kao odvojeni fenomen, onaj koji okuplja različita sjećanja u smislenu cjelinu za širu grupu (zajednice) ili barem dio grupe. Reprodukcijom sjećanja (čak i tuđih) stvara se korpus mišljenja koji se ritualno ili materijalizacijom vrednuje kao važan. U obranu heterogenih sjećanja kao konstitutivnih dijelova kolektivnog sjećanja, Halbwacks će objasniti da kada bismo ostali pri pojedinačnoj svijesti, sjećanja koja bismo reproducirali ostala bi nepromjenjiva. Ali kada se rekonstrukcija ${ }^{94}$ vodi naporom rasuđivanja, dešava se da sjećanja bivaju iskrivljena. Tome je tako zato što ih se želi oblikovati da budu koherentnija (Halbwacks 2013: 310). Možemo reći da se sjećanja reaktualiziraju i smještaju u sadašnjost. Ona

\footnotetext{
${ }^{93}$ Rovinjka je iznimno karakterna žena.

94 “U vezi sa grupom postoji još jedna karakteristika koja je u uskoj vezi sa kolektivnim pamćenjem: to je njena rekonstruktivnost. Time se misli da nijedno pamćenje ne može da sačuva prošlost kao takvu, već da od nje ostaje samo 'ono što društvo u svakoj epohi može da rekonstruiše u skladu sa svojim spoljnim okvirima’ (1985a, 390)” (Assman 2007: 39).
} 
moraju biti relevantna u sadašnjim kontekstima. Halbwacks će zaključiti da su preobražavanja moguća i korisna upravo zato što odgovaraju kolektivnom iskustvu, "ako ne jednako starom, a ono barem mnogo širem, znači da su zajedničke ne samo (kao tradicije) pripadnicima dotične grupe, već i pripadnicima drugih grupa iz toga vremena" (ibid.: 311).

U svom istraživanju modaliteta sjećanja i pamćenja Alke, Ana-Marija Vukušić naglašava "da bi se osvijestila važnost nekog događaja, odnosno da bismo ga rekonstruirali sjećanjem, moramo uspostaviti odnos prema njemu: moramo 'osjećati' neke njegove posljedice kao 'dokaze' prošlih zbivanja” (Vukušić 2013: 124). Vezu sjećanja i kulturnog pamćenja pronalazim upravo u reaktualizaciji, odnosno suvremenom (nelinearnom) vremenu potrebnom da se nečega prisjetimo.

Kao prijenosne mehanizme društvenog pamćenja (što bi prema Assman i u kontekstu ovog rada bilo zapravo kulturno pamćenje), Peter Burke navodi memoare, usmene predaje, fotografije, rituale... (Burke 1999: 85), a koji su važni ne samo kao instrumenti za uspostavu sjećanja već i stoga jer su odraz želje da se prošlost tumači na određeni način te da se tako oblikuje pamćenje (Vukušić 2013: 124). Međuodnos sjećanja i pamćenja je još jednom apostrofiran. Društvo određuje što je vrijedno pamćenja, ali se (kolektivno) pamćenje održava individualnim, društveno interaktivnim sjećanjem. Kod svakog od ovih fenomena (pa čak i povijesti) moramo voditi računa o “svesnom i nesvesnom izboru, tumačenju i iskrivljavanju” (Burke 1999: 84).

Dok se Halbwacks usredotočuje na kolektivno, te na suodnos individualnog i kolektivnog, Jan i Aleida Assman odlaze korak dalje te otkrivaju distinkciju među različitim oblicima kolektivnog pamćenja. Ponovit ćemo, za naše je istraživanje značajan argument Aleide Assman da je društveno pamćenje međugeneracijsko, a kulturno transgeneracijsko. U kontekstu rovinjske industrijske prošlosti, transgeneracijsko prenošenje temelj je suvremenih percepcija pozicije rovinjskih radnica u periodu od 1872. do 1970. godine. Ovim istraživanjem bilo je nemoguće doći do značajnijih informacija, kako tekstualnih tako i vizualnih o sardellinama, ženama $\mathrm{u}$ riboprerađivačkoj industriji. Možemo se pitati zbog čega su informacije (u vidu pisanih 
i vizualnih izvora i sjećanja pojedinaca) o najranijim radničkim iskustvima sardellina nedostupne. Je li rovinjsko društvo odlučilo pamtiti isključivo tabacchine? Što je utjecalo na takvu odluku? Je li prestiž koji su one svojim izgledom, plaćom i radom za carski monopol reflektirale $u$ inače osiromašenom ribarskom i poljoprivrednom gradu generirao tu poželjnu sliku, sliku koju vrijedi pamtiti? U pronalaženju odgovora koristit ćemo se Burkeovim prijedlogom prijenosnih mehanizama kolektivnog pamćenja.

\section{1. Fotografije kao prijenosni mehanizam kulturnog pamćenja}

Pretpostavit ćemo da velika većina rovinjskih građana nije imala priliku čitati povijesnu studiju Storia documentata di Rovigno objavljenu prvi put 1888. godine, a zatim još dva puta u izdanju Famia Ruvignisa, organizacije koja okuplja rovinjsku emigraciju nakon 1947. Isto je vjerojatno za Džebin Duhanski put u Rovinj (1987) koji predstavlja stoljetnu povijest Tvornice duhana Rovinj. Pretpostavke se temelje na činjenici da su edicije bile brojčano ograničene te ih je i danas gotovo nemoguće kupiti, obrazovni sistem ih ne koristi niti promovira, a dio izvora je dostupan isključivo na talijanskom jeziku. Ako znamo da su to, ako ne jedina, onda barem najvažnija ili obuhvatnija djela koja se donekle bave poviješću rovinjskog (duhanskog) radništva na prijelazu stoljeća, nužno je istražiti ostale mehanizme (Burke 1999) koji podupiru društveno (kulturno) pamćenje.

Za takav poduhvat nužno je preispitati i istraživačke metode koje su obilježile etnologiju prvih desetljeća. Promatrajući svijet oko sebe, etnografi su se prvenstveno oslanjali na vizualnu percepciju. Empirizam i racionalizam, filozofski temelji zapadnih znanstvenih disciplina, objašnjavaju spoznaju koju osiguravaju osjetila u kontekst pribavljanja informacija kako bi se predstavile u umu. Osjetilo vida upravo zato dostiže primat nad ostalim osjetilima jer olakšava konstruiranje izvanjskoga svijeta (Bagarić 2013: 85). Međutim, Etami Borjan zaključuje da u antropologiji dolazi do svojevrsnog paradoksa, jer iako su zapadne kulture još od antike dokazivale okulocentričnost, tekst je do danas zadržao status vjerodostojnijeg medija reprezentacije (Borjan 2013: 34), baš kao što i druge“"...nauke koje se bave rekonstruisanjem ljudske prošlosti, po pravilu su obraćale najviše pažnje na pisane dokumente, zanemarujući, ili pridajući znatno manje 
pažnje, ostalim vrstama izvora, smatrajući ih manje objektivnima, pa tako i manje vrednim nosiocima podataka“ (Gavrilović 2004: 6).

U svojoj doktorskoj disertaciji Balkanski kostimi Nikole Arsenovića Ljiljana Gavrilović veliki dio istraživanja posvećuje upravo vizualnoj građi kao izvoru za saznavanje. U toj analizi, autorica zaključuje kako ne postoji izvor, osim materijalnih ostataka, u kojem nije prisutan i subjektivni stav autora formiran na osnovu sistema vrijednosti kulture, društva i socijalnog sloja kome pripada. S druge strane materijalni ostaci osim podataka o genezi forme i ukrašavanja predmeta ne mogu dati podatake o načinu njihovog korištenja. U nedostatku sačuvanih predmeta, što je veoma često $s$ obzirom na propadanje materijala ili praksu čuvanja samo primjeraka izuzetne društvene ili ritualne vrijednosti, likovni materijal nam postaje najbitniji izvor čak i za utvrđivanja načina izrade, oblika i ukrašavanje predmeta. Uz izvore iz domene likovne umjetnosti, posebno je važno primjetiti kako određeni vizualni izvori, posebice od 19. stoljeća dalje, nastaju u cilju dokumentarnog bilježenja stvarnosti te ih, unatoč svim ograničenjima koji se tiču teorijsko-metodološkog opredjeljenja i predznanja autora te ciljeva istraživanja, kako Gavrilović zaključuje, možemo i moramo tretirati kao potpuno ravnopravan izvor za istraživanje, posebno jer u periodu njenog nastanka nisu postojale bolje tehnološke mogućnosti bilježenja materijalne kulture (vidi Gavrilović 2004: 20-23).

"Najstarija sačuvana slika tabacchina potječe iz 1882. Snimio ju je neki fotograf iz Pariza, a jedan je pisac ovako doživljava: One su ukočene kao kipovi. Njihova lica odaju ozbiljnost, nijedna se ne usuđuje nasmiješiti. Najposlije, doživljavaju suočavanje s besmrtnošću. Dale su se ovjekovječiti pa su za tu priliku odjenule svoju nedjeljnu odjeću" (Džeba 1987: 78). Džebin pjesnički osvrt na fotografiranje tabacchina 1882. moguće je sagledati i u kontekstu tadašnje tehnologije koja je podrazumjevala da fotografirani subjekti dulje vrijeme stoje nepomični kako bi fotografija uopće uspjela. Fotografije su bile rijetkost, a razlog fotografiranja veže se uz promociju carskog monopola. Bilo je nužno, dakle, pokazati raskoš i bogatstvo Carstva, pa je moguće da su radnice odjenule najljepšu odjeću jer im je tako i rečeno. Postavlja se i pitanje kako su se odijevale Rovinjke krajem 19. stoljeća. Iako povijesni izvori svjedoče razmjernom 
bogatstvu od 17. stoljeća nadalje, isto je ograničeno na bogatije obitelji. Ono što se vidi na najstarijoj fotografiji rovinjskih tabacchina jesu ukočena lica, ali i skromna odjeća kojom dominira duga suknja i pleteni šal prebačen preko ramena. Teško je uočiti nakit od zlata koji bi se bogato spuštao na prsa radnica.

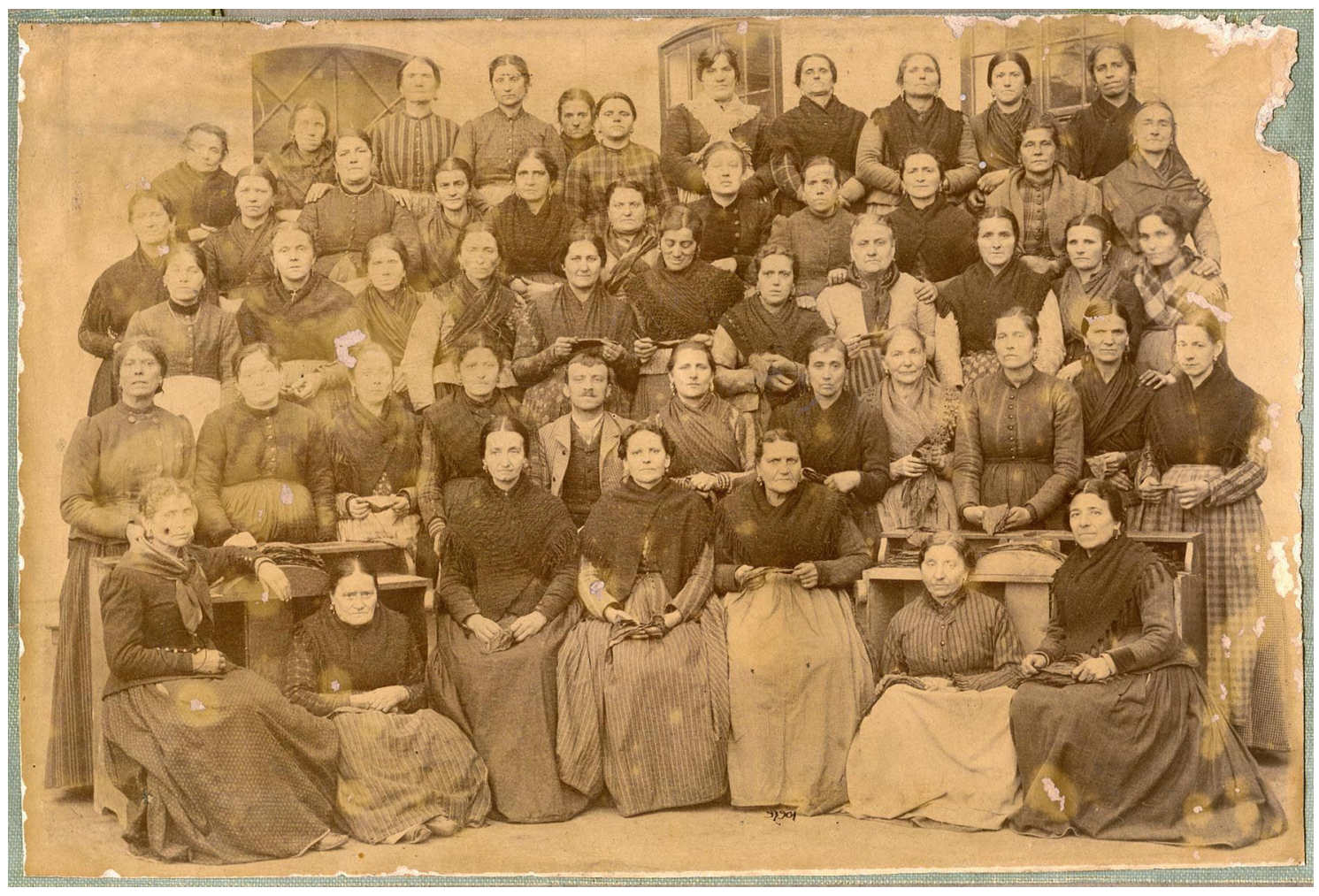

Slika 17. Prva sačuvana fotografija tabacchina, 1882.; 173-1_F Muzej Grada RovinjaMuseo della città di Rovigno

O važnosti tvornice za carski monopol svjedoči količina fotografija koje se čuvaju u Muzeju Grada Rovinja-Museo della Città di Rovigno. Jedna od najreprezentativijih i najprisutnijih u javnom prostoru je ona iz 1907. godine. Osim elegantne odjeće u koju su se radnice za tu prigodu spremile, elegantni passepartout dodatno odaje prividno bogatstvo, uspjeh, prestiž i nadmoć. Također, postoji cijela serija fotografija iz 1894. godine nastalih vjerojatno povodom prve modernizacije Tvornice (Ujčić 2014: 5) i serija iz 1908. snimljena prigodom obilježavanja jubileja cara Franje Josipa I. 18. 8. 1908 (ibid: 24). 


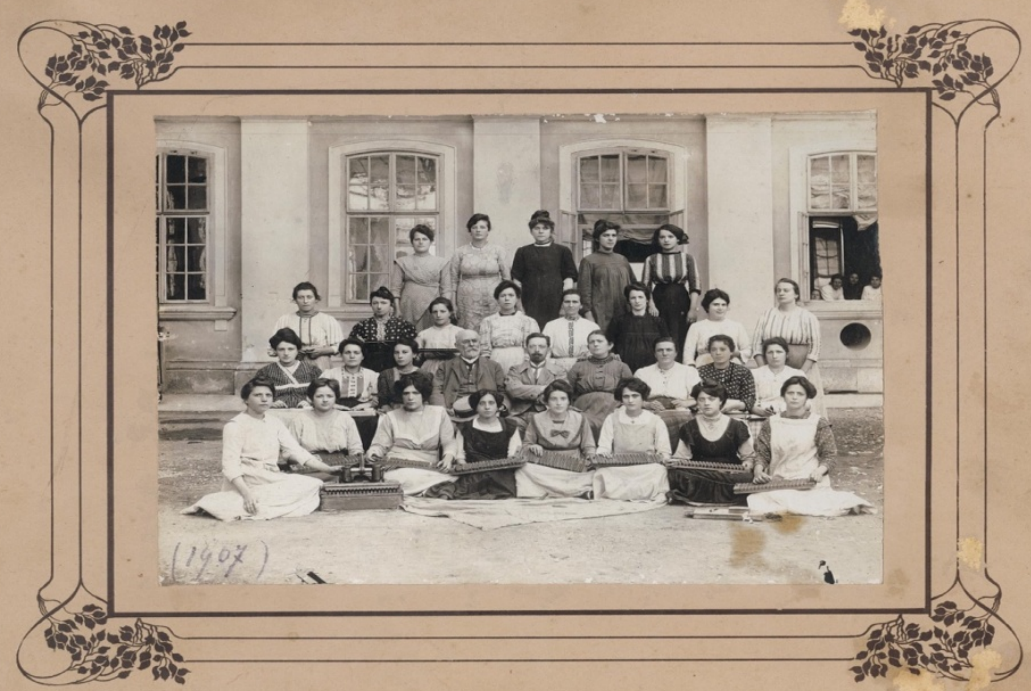

Slika 18. Tabacchine, 1907. ZMGR 170-1-F-2 Muzej Grada Rovinja-Museo della città di Rovigno

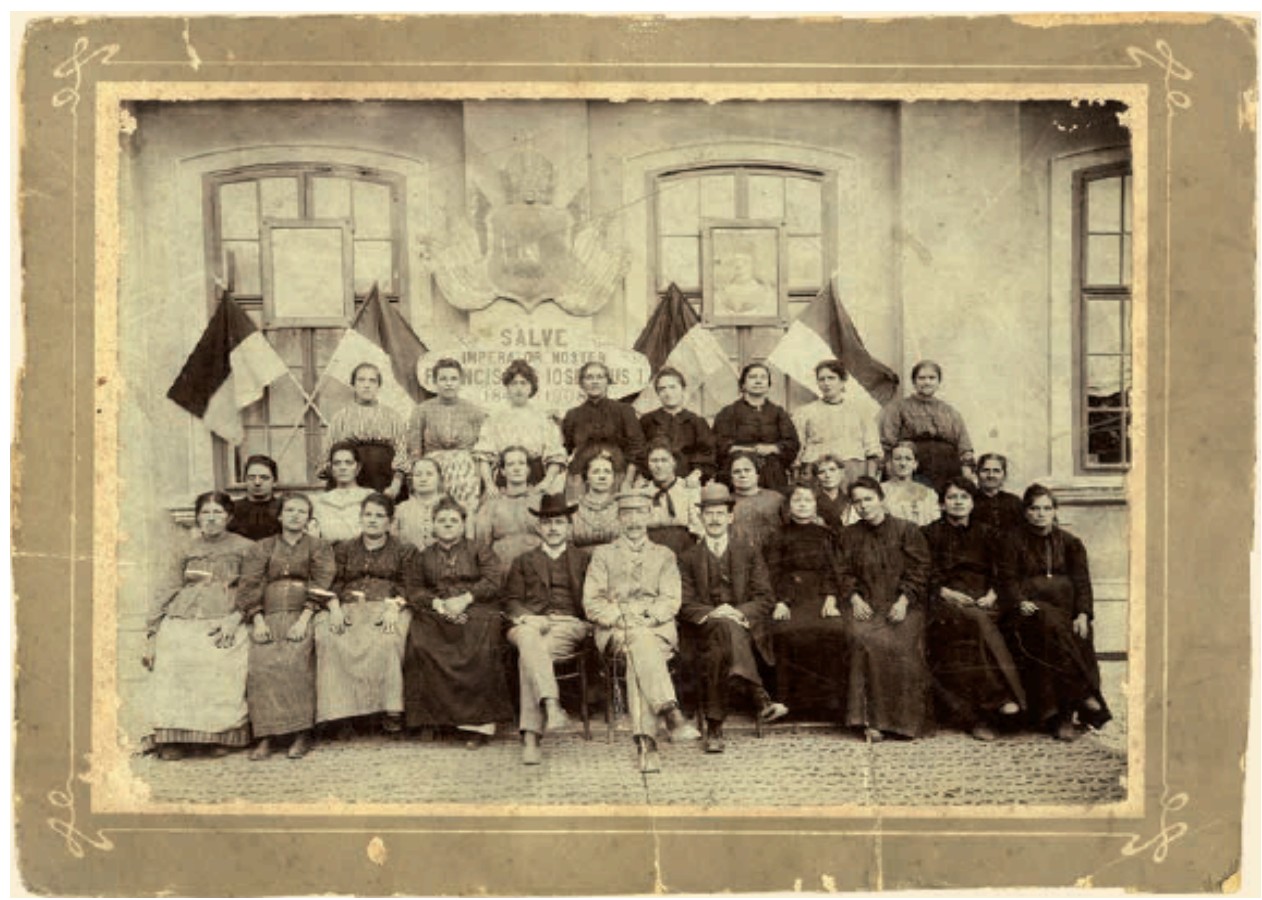

Slika 19. Tabacchine s poslovođama, 1908. ZMGR 127-1/F (22/61) Muzej Grada Rovinja-Museo della città di Rovigno 
Fotografije s početka stoljeća, gdje je zamjetna promjena mode odijevanja i frizure ali i pomlađeni radnički kolektiv, često se pojavljuju u prigodnim kalendarima, na izložbama, a posljednjih petnaest godina krasile su i zidove kafića smještenog nadomak Tvornice, a koji nosi upravo naziv Tabacheina. ${ }^{95}$ Takva slika je ona poželjna, koja se generacijama prezentira javnosti, najčešće bez popratnog komentara. Razvoj TDR-a kroz vizulane materijale moguće je pratiti do danas. Takva mogućnost direktno je utjecala na oblikovanje kulturnog pamćenja radnica duhanske industrije. Isto nije ograničeno na prve carske godine, već i na kasnije periode talijanske i jugoslavenske uprave. Kako se ta mogućnost reflektirala na osobna sjećanja zorno nam ocrtava slijedeći primjer.

Sjećanja su najčešće uvjetovana osobnim iskustvom koje je ponekad u kontradikciji s društvenim pamćenjem, no sjećanje se može generirati i na druge načine. U našem se radu sjećanje odnosi na evokaciju druge i treće generacije predaka, dok življena iskustva, također prizvana u sjećanje s obzirom na odmak od nekoliko desetljeća i s jednakom mogućnosti selekcije, iako vrijednosno različita, nikako ne znači da su i točnija. Sládeček i Vasiljević navode primjer neuropsihologa Olivera Sacksa, koji opisuje (proživljeno) iskustvo bombardiranja Londona. No kada je autor razgovarao $\mathrm{s}$ bratom o tom događaju, saznao je da on $\mathrm{u}$ to vrijeme uopće nije bio $\mathrm{u}$ Londonu. Svoje je sjećanje nesvjesno izgradio temeljem pročitanog potresnog i živopisnog pisma i prisvojio ga kao vlastito iskustvo (Sládeček i Vasiljević 2015: 7).

Pokazat ću da se slično dešava i s rovinjskim sjećanjima. Žene prenose generičke informacije o prestižu i pjesmi kao vlastita sjećanja, iako u to vrijeme nisu bile ni rođene. To nije bilo njihovo neposredno iskustvo. One su ta sjećanja usvojile kao svoja, temeljem priča majki i baka, fotografija koje su možda vidjele u nekoj publikaciji ili već spomenutom kafiću Tabacheina.

Ono čega se ja sjećam pored tog reda, kontrole, discipline, higijene... to su saloni prepuni žena i sve su imale one bijele kape da im kosa ne bi upadala $i$ dvoranom se orila pjesma. One su na sav glas pjevale od jutra do mraka. Ta harmonija i pjev su donijeli jako puno (M. R.).

\footnotetext{
${ }^{95}$ Rovinjski dijalekt, ruvignis.
} 


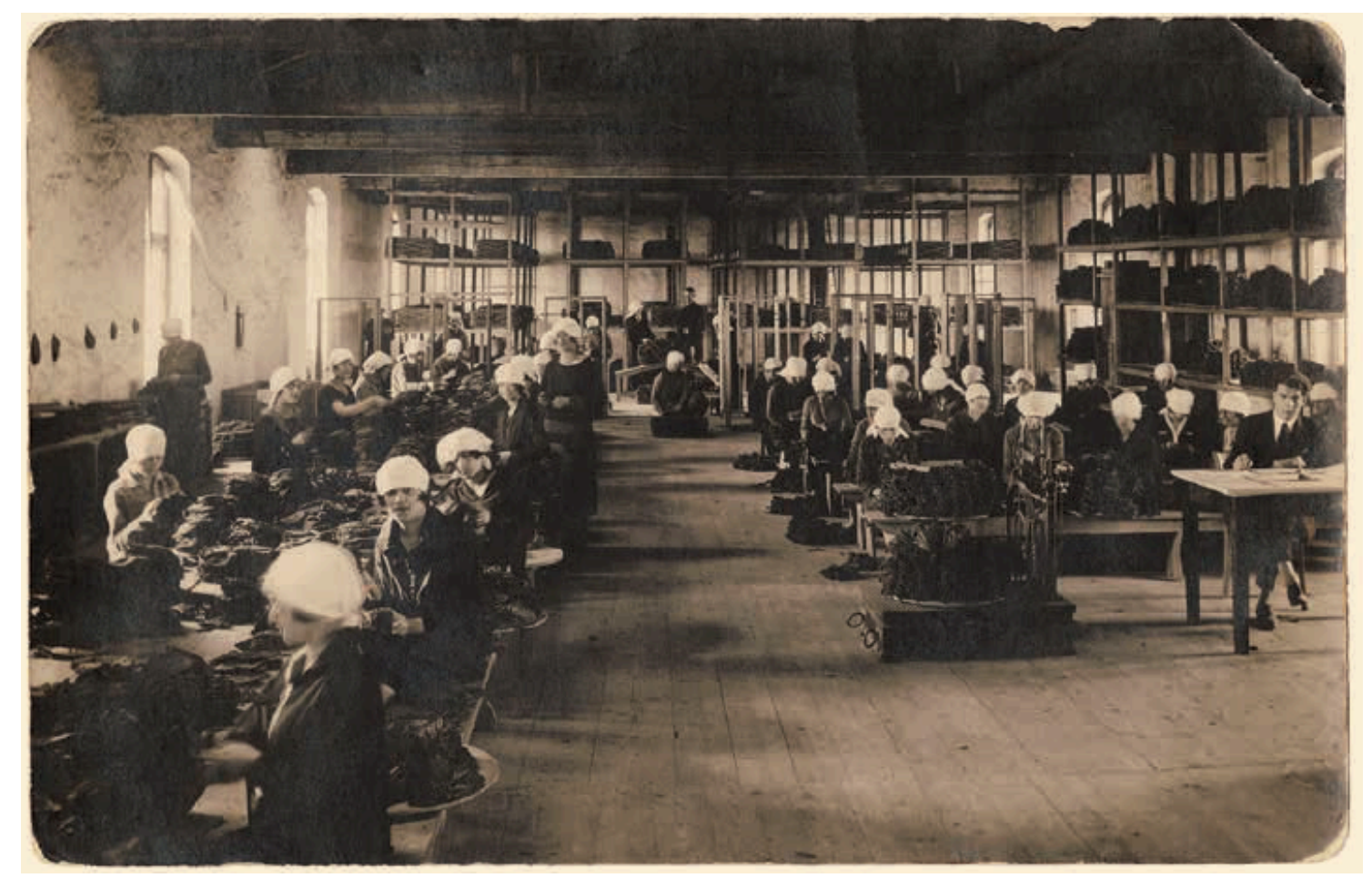

Slika 20: Radnice (tabakine) u pogonu za sortiranje lišća, 1920-te. ZMGR/ MCCR 1/F16. Muzej Grada Rovinja- Museo della città di Rovigno

Ranih fotografija sardellina nema. Muzej Grada Rovinja čuva nekoliko fotografija iz kasnih 1930-ih. Iste nisu raskošne ni reprezentativne. Njihov se rad snažnije bilježi od vremena socijalizma, kada se tvornica nacionalizira i kada je nužno pokazati ravnopravnost i požrtvovan rad radničke klase u obnovi zemlje. ${ }^{96}$ Dvije kazivačice s kojima sam za potrebe ovog rada razgovarala, ponosno su mi pokazale isječke iz školskih udžbenika. Na fotografijama su upravo one za vrijeme rada u Mirni. Simptomatični su i opisi, ispod jedne slike stoji Prerađivačice u Mirni: Nije bilo zastoja u proizvodnji (vidi ovdje str. 155). Kako je naglašeno, osim proklamacije ravnopravnosti muškaraca i žena na radnom mjestu, fotogarafski je materijal korišten i kao dokaz efikasnosti tadašnje ekonomije.

96 “Očekivano, prvih godina nakon rata Žena u borbi, glasilo Antifašističke fronte žena Hrvatske (izlazi od travnja 1943. godine), slijedi sovjetske uzore, poput časopisa Rabotnica (usp. Attwood 1999: 26-30). Naslovnice, fotografije na unutrašnjosti korica i fotografije uz članke većinom prikazuju radnice na njihovim radnim mjestima u tvornicama ili, rjeđe, u polju ili znanstvenoistraživačkom laboratoriju." (Senjković 2018: 178) 


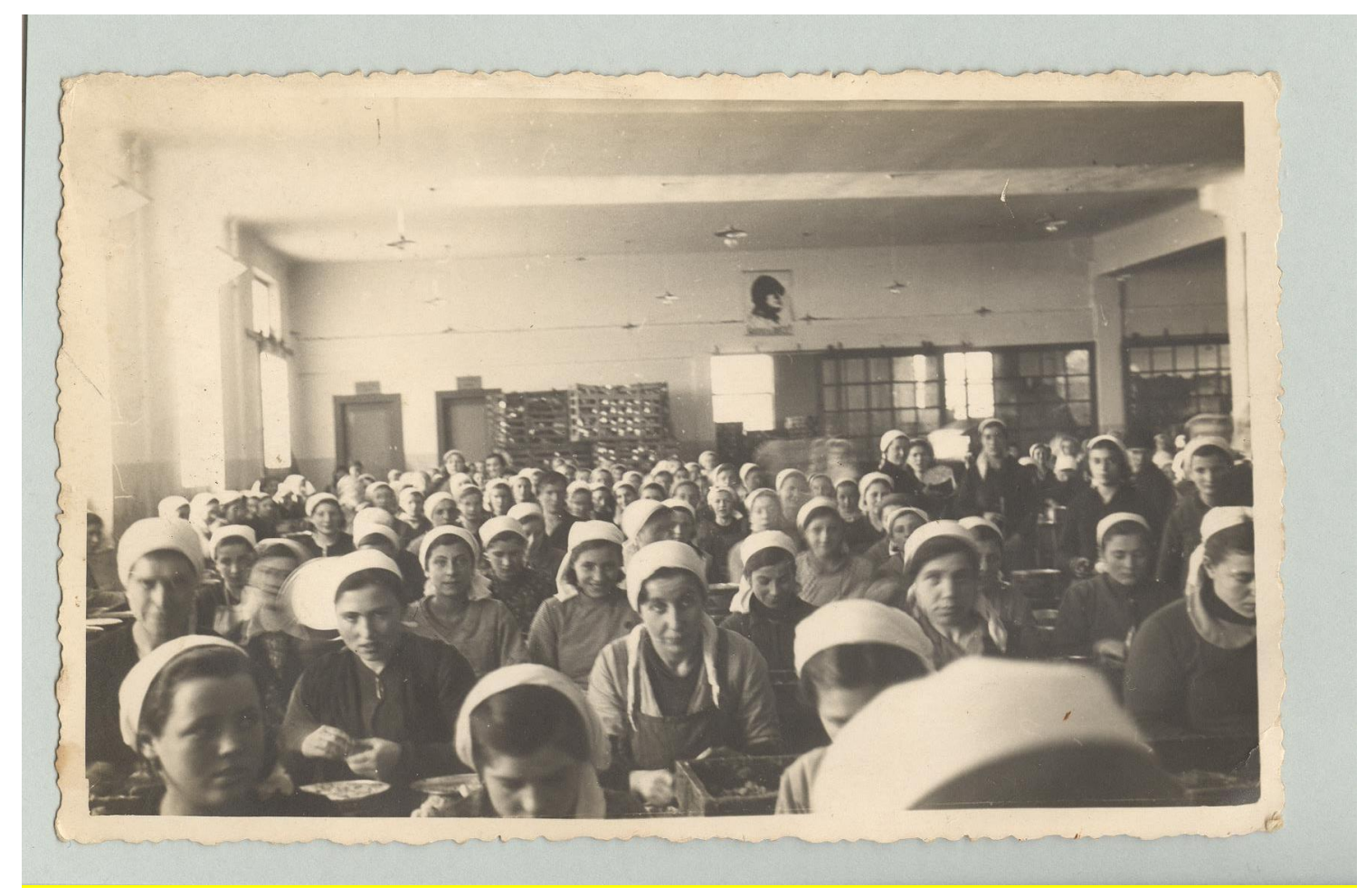

Slika 21: Brojnost radnica tvornice za preradu ribe i rad u skučenom prostru 1930-ih godina vjerno nam prenose fotografije Muzeja Grada Rovinja-Museo della Città di Rovigno

\section{2. Folklorna građa i reprezentacijski intersekcionalizam}

Rovinjski folklorni opus $\mathrm{u}$ nekoliko se slučaja referira na rovinjske radnice $\mathrm{u}$ duhanskoj industriji. To su u prvom redu pjesme La tabacheîna, anonimnog autora i $L a$ tabachina (1928.) skladatelja Carla Fabretta. Kao dio svog repertoara pjesme redovito izvodi KUD/SAC Zajednice Talijana P. Budicin "Marco Garbin” iz Rovinja. Pjesmu anonimnog autora izvela je i Lidija Percan, te je za istu snimila video spot na ulicama Rovinja 1987. godine. Pjesme se izvode u veselom tonu, a u trenutku kad pjevačica pjeva dio teksta u prvom licu, imitirajući tabacchinu, njena gestikulacija i izraz lica reflektiraju gordost ili ponos. 
La tabacheîna, Anonimo

(e ciume, ciume)

A nu fà gniente sa ti son in tiera

cun la mia paga i vivaremo

e l'intrada i la salvaremo,

i staremo nama ca ben.

E ciume, ciume, son tabacheîna

la quindifeîna i ta purtariè;

e ciume, ciume, son tabacheîna

doûti i suoldi i ta dariè.

Preîma da ciù oûna tabacheîna

i ma cuntento pagà la tàsa,

el tabàco ma la ruveîna; (var. i

surviglianti

ma la ruveîna; i surviglianti ga tùca el coûl

oppure: ga palpa el coûl)

la tabacheîna i nu la vuòi nuò.

E ciume, ciume, son tabacheîna

la quindifeîna i ta purtariè;

e ciume, ciume, son tabacheîna

doûti i suoldi i ta dariè.
Tabakina, Nepoznati autor

(uzmi me, uzmi me)

Nije mi vašno što si na dnu

živjet ćemo od moje plaće

sačuvat ćemo ljetinu,

i još ćemo solidno živjeti.

Uzmi me, uzmi me, ja sam tabakina

svakih petnaest dana donosim plaću;

uzmi me, uzmi me, ja sam tabakina

moj će novac biti tvoj.

Prije nego što uzmem tabakinu

s veseljem ću platiti porez,

jer zbog duhana ima mušice u glavi;

(var. nadzornici mi je salijeću;

nadzornici

joj dodiruju stražnjicu ili: je štipaju po stražnjici)

i ni pod koju cijenu neću tabakinu.

Uzmi me, uzmi me, ja sam tabakina

svakih petnaest dana donosim plaću;

uzmi me, uzmi me, ja sam tabakina

moj će novac biti tvoj.

U razgovoru sa studentom etnomuzikologije iz Rovinja, saznajem da je pjesma La tabacheîna, "najvjerojatnije parodija austrijske pjesme koja je pak parodija tršćanskih, to je bilo normalno, a nastala je najvjerojatnije za vrijeme talijanske uprave $\mathrm{i}$ aktivnosti tvorničkog zbora." Nejasna geneza pjesme, otvara nam mogućnost da ista nastaje i ranije, još za vrijeme Austro-Ugarske s obzirom da postoje elementi koje dijeli s trašćanskim i austrijskim varijantama sličnih pjesama. 
Analizom teksta možemo uočiti neke referentne točke ekonomskog i društvenog položaja tabacchina. Radnica se nudi potencijanim mladoženjama koji pripadaju jednom od siromašnijih slojeva građana, poljoprivrednicima. Kao svoju prednost, tabacchina navodi stalnu plaću koja će im omogućiti da sačuvaju ljetinu, odnosno da imaju dovoljno za život. Mladić odgovara da je ženidba za tabacchinu posljednje što bi učinio te navodi dva ključna razloga; od duhana postaje mušićava, što možemo tumačiti kao posljedicu stalne zarade u duhanskoj industriji zbog koje radnice postaju umišljene i potencijalno karakterno neusklađene s potrebama mirnog bračnog života, a drugi razlog se ogleda u činjenici da nadglednici u tvornici seksualno uznemiravaju radnice, kao što pjesma kaže: dodiruju im ili štipaju stražnjicu.

Predstavljanje tabacchina kao mušićavih, slobodnih manira i relativno bogatih utjecalo je i na percepciju povijesti radništva u Rovinju. Stogodišnje ponavljanje ovih stihova bez kritičke analize, dovelo nas je do situacije da se uvredljivi stihovi pjevaju bez razumijevanja u sklopu zabava predstavljajući dio identiteta rovinjske zajednice. Kao jedan od mogućih uzroka je i činjenica da se pjesma izvodi na starom rovinjskom dijalektu koji razumije tek $1 \%$ stanovništva, vjerojatno i manje. Simptomatično je pritom da pjesma do nas dopire kao ona koja slavi tabacchine, a zapravo, kako smo mogli iščitati, tabacchine se kroz pjesmu uglavnom ismijavaju i ponižavaju. Riječi pjesme su u potpunoj suprotnosti s onime što Rovinjci pamte kao kvalitete radnica. Pozitivnu sliku omogućavaju raskošne fotografije i elementi koji se u pjesmi referiraju na ekonomski status tabacchina. Selektivno pamćenje briše negativne konotacije, stvarajući idiličnu sliku prošlosti. Međutim, folklorna reprezentacija je istovremeno subverzivna i nudi razumijevanje suprotno od dominantne (ekonomske, kapitalističke) politike, te ukazuje na subordiniran položaj žena u odnosu na muškarce, a indirektno i subordiniran položaj ne-radnica u odnosu na radnice. S druge strane stereotipi koji se na ovaj način proizvode dovode u nepovoljan položaj sve radnice Tvornice duhana. Kulturološke konstrukcije generirane kroz folkor ili popularnu kulturu, a sagledane kroz prizmu reprezentacijskog intersekcionalizma, otkrivaju stereotipe koji se bezrezervno pripisuju cijeloj grupi stavljajući žene radnice u nepovoljni položaj i osnažujući time dodatno njihovu društvenu i klasnu podređenost (usp. Crenshaw 2012: 1282-1295). 
Druga pjesma, ona Carla Fabretta ${ }^{97}$, je manje kritična prema tabacchinama i reflektira većinu pozitivnih stereotipa koje smo dosad detektirali.

La tabachina, Carlo Fabretto 1928.

Me levo a la matina bonora, inverno e istà, perché son tabachina me ciama "el dasparà"; ma no per questo a casa no fasso el mio dovèr: mi meto duto a stasa e lustro el fogolèr.

REF: Ma no' parleme de robe d'amor:

Mi qua credeme, ragiono col cor; val più un bel omo che ' 1 me voia ben che le sterline che duti ghe tien!

Me porto ne la borsa un po' de pan e vin: xe quel che dà la forsa e ne tien su el morbìn! E quando che la sera finido go el lavor, spassìso per Carera in serca del mio amor.

Per farme un bel coredo go tanto sparagnà e adesso me lo vedo che ' 1 xe una rarità. Xe tante signorine che marcia in capilìn Ma de le Tabachine non le lo ga più fin.
Tabakina, Carlo Fabretto 1928.

Krećem od jutra, rano ranim, i zimi i ljeti, jer ja sam tabakina a “očajnik” zove; ali zbog toga kod kuće ne izbjegavam svoje dužnosti: sve držim pod kontrolom i glancam ognjište.

REF: Ne pričajte mi o ljubavi: vjerujte mi, razmišljam srcem; vrijedi više zgodan muškarac koji me voli od novca do koga svatko drži!

U torbi nosim malo kruha i vina: oni daju snagu i održavaju raspoloženje! A kada sam navečer završila s poslom, šećem po Careri u potrazi za svojom ljubavi.

Dugo sam štedjela da pripremim miraz i sada ga gledam kako je poseban. Mnoštvo je gospođica koje nose šešir ali ni u jedne miraz nije kao kod tabakine fin.

\footnotetext{
${ }^{97}$ Fabretto, Carlo, učitelj, glazbeni pedagog, skladatelj i sakupljač narodnog glazbenog blaga (Kopar, 16. V.1883. - Rim, 25.III.1969.). Školovao se u pulskom liceju iz kojeg je izbačen jer je istukao sina austrijskog časnika, a zbog gorljivog talijanskog iredentizma kao 14-godišnjak završio je u zatvoru. U Beču se upisao na medicinski fakultet, ali je i s njega izbačen zbog iredentističkog aktivizma kada seli u Rovinj. Rovinj je odmah zavolio jer su mu i roditelji imali rovinjske korijene, i u tom je gradu ostavio traga kao učitelj, posebno u glazbi. Podučavao je violinu, vodio je pjevačke zborove, a autor je više pjesama koje su postale dio rovinjske glazbene tradicije poput Vien, Fiamita (poznata i kao Vien sul mar), Vignì sul mar muriede (poznata i kao La sira la xì biela), Rovigno bella... (...) 1924. komponirao je četiri operete (iz Omi da pera je poznata škrčeva pjesma Sa nu zì biessi ili El suldeîn), slijedio je i niz popularnih pjesama: El mariner (1926.), La tabacheîna (1928.), Faviela el sapadur (1930.). (Izvor: istrapedia.hr/ pristup 1. 10.2019.)
} 
U pjesmi Carla Fabretta prepoznajemo elemente na koje smo nailazili u brojnim kazivanjima. Pjesma predstavlja tabacchinu kao vrijednu radnicu koja ne zanemaruje svoje kućanstvo i koja nakon radnog dana odlazi u šetnju u potrazi za ljubavlju. Ona je pripremila dobar miraz koji je bolji čak i od onoga djevojaka više klase, okarakterizirane kao one koje šetaju sa šeširom. Međutim, element koji je interesentniji i koji 'otkriva' drugu stranu tabacchine nalazi se u refrenu. Tabacchina naime, poziva slušatelje da joj vjeruju, jer njoj više vrijedi ljubav nego novac.

Kao što je uobičajeno za folklornu i popularnu produkciju, pjesma obiluje stereotipima. Iste je moguće interpretirati na dva načina koji će doprinijeti boljem razumijevanju pozicije i uloge duhanskih radnica početkom 20. stoljeća. Najprije se možemo pitati zašto tabacchina poziva da joj se vjeruje. Moguće zato što su već i tada stereotipi toliko jaki, pa joj je važno naglasiti kako nju ne zanima novac već ljubav. Nadalje, ovi stihovi, zajedno s onima iz prve pjesme koju sam predstavila, otvaraju novu perspektivu na status rovinjskih duhanskih radnica; iako imaju novaca, one nisu uvijek i svima poželjne udavače. Postoje i druge karakteristike koje su se tadašnjim mušakrcima mogle učiniti važnijima za brak od samog novca. U ovom kontekstu značajno je kazivanje koje govori o specifičnom statusu rovinjskih radnica koje su nakon Drugog svjetskog rata emigrirale na Sardiniju. Ovdje ih je dočekala konzervativnija zajednica kojoj se nije uvijek sviđao njihov 'slobodniji' način ophođenja.

Sloboda koja se rađa iz ekonomske neovisnosti često je krivo shvaćena. Mogu ti reći iz osobnog iskustva. Poznavala sam nekoliko Rovinjki iz Fertilije na Sardiniji koje su emigrirale 1947. Uglavnom, njihovo je ponašanje bilo, uobičajeno za nas, otvoreno. Međutim, u zatvorenoj pastirskoj zajednici, takvo je ponašanje bilo snažno osuđivano. Doslovno indikator niskog morala. Smatrali su ih nedoličnima, da se pristojno izrazim. (A. R.)

Prema tome, pjesme nam otvaraju mogućnost razbijanja stereotipa o poželjnim udavačama, ali i one o njihovoj pretpostavljenoj mušičavosti, umišljenosti i želji za materijalnim bogatstvom. 


\section{3. Muzeološko djelovanje na kulturno pamćenje radnica}

Iako rovinjska kulturna scena ne pamti veću izložbu na temu radnica industrijskih pogona, iz kataloga izložbe E ciume, ciume, son tabacheina-Rovinsjke tabakine na starim fotografijama autora Tajane Ujčić i Alda Klimana, saznajemo "...da je 1972. godine Zavičajni muzej grada Rovinja, odnosno tadašnji direktor Anton Pauletić organizirao izložbu povodom 100-te godišnjice Tvornice duhana u Rovinju”. Kako nas kustosica dalje izvještava, dokumentaciju i podatke o toj izložbi (još) nemamo (Ujčić 2014: 7). S obzirom da Ujčić navodi podatak kako se na pojedinim fotografijama prikupljenima za potrebe te izložbe nalaze podaci donatora, za pretpostaviti je da je izložba iz 1972. bila fotografska, baš kao i ona koja je 2014. postavljena u istom muzeju.

Katalog izložbe iz 2014. donosi uvodni tekst s povijesnim informacijama o osnutku Tvornice, tekst tradicijskih pjesama koje smo ranije analizirali i reprint 18 fotografija iz austrijskog perioda i 2 fotografije iz talijanskog perioda. Sve ove informacije zaljubljenicima u povijest bit će već poznate, ali je muzej napravio iskorak u općoj popularizaciji radničkih identiteta. Na žalost, izložbi i katalogu nedostaje kritički osvrt na tvorničke uvjete rada. Ponavljanjem informacija i slika, dotad razvijen imaginarij o radnicama još se više osnažuje. Tome doprinosi činjenica da se u izložbama prikazuju najstarije fotografije radnica koje, zahvaljujući modi prvih godina 20. stoljeća, današnjoj publici mogu djelovati otmjenije nego li je to zaista bilo. Već se 1920-ih uočava promjena u odijevanju radnica. Tada počinju nositi uniforme i bijele kapice koje su zasigurno osiguravale više higijenske standarde, ali su umanjile eleganciju radnica. Selekcija fotografija za izložbu i katalog ne prati tehnološka dostignuća fotografije. Očekivalo bi se da kako godine prolaze, fotografija ima sve više, međutim kustosi izložbe selekcijom najstarijih osnažuju povijesni mit i ne nude publici priliku upoznati radničke vizuale od 1930-ih nadalje. Uzmemo li u obzir naslov izložbe i kataloga koji jasno ukazuju na želju za predstavljanjem 'starih i povijesnih' fotografija, možemo se samo pitati koji su kriteriji kojima su određeni povjesnost i starost fotografija. U današnjem digitalnom dobu fotografije iz 1990-ih već se smatraju starima, a suvremene povijesne prakse, između ostalog, bilježe i interpretiraju 
današnjost i recentnu povijest. Iako se granicom koja označava početak novije povijesti i dalje smatra kraj Prvog svjetskog rata, svjesni smo brojnih praksi koji navode na nužnost razmatranja takve podijele.

Svojevrsnu nadopunu i ispravak manjkavosti izložbe i kataloga nalazimo u recenziji koju potpisuje viša kustosica Povijesnog i pomorskog muzeja Istre-Museo storico e navale dell'Istria Katarina Marić. U recenziji stoji:

"'La tabacheîna' nepoznatoga autora, u čijim se šaljivim stihovima tabacheîna hvali upravo svojom državnom plaćom koju svakih petnaest dana nosi kući, nalazimo i odgovor mladića koji za njih misle da su mušićave i sklone udvaranju. O istoj temi govori i pjesma 'La tabacchina' Carla Fabretta iz 1927., prema čijim su stihovima one mogle kupiti sve osim zgodnoga muškarca. Stihovi obje pjesme imaginarna su audiokulisa i daju emocije likovima s fotografija, a okosnica su izložbe" (Marić 2015: 371). U zaključku Marić naglašava "Radnice Tvornice duhana uvijek su bile simbol Rovinja i dio su ukupne memorije grada. Prikazane su u najljepšoj odjeći, s nakitom, ponosno predstavljajući proizvode svojega rada. Međutim, stvarnost nije uvijek bila tako idilična kako je prikazana u trenutku zaustavljanja vremena fotografijom. Ponosno poziranje pred zgradom tvornice, kao i šetnja sa šeširima i suncobranima Carerom ili nekom drugom ulicom, nisu mogli prikriti umorna lica relativno mladih žena. Fotografije s nekim poznatim i većim dijelom nepoznatim licima stavljaju stanovnice i stanovnike Rovinja u povijesni kontekst razvoja periferije Austro-Ugarske Monarhije i Kraljevine Italije te promjena koje su se tijekom vremena događale u društvenom, gospodarskom pa i kulturološkom smislu“ (ibid: 373). Na žalost dostupnost kataloga, a još i više recenzije, nije na zavidnoj razini. Stoga, ovakve kritičke crtice uglavnom ostaju ispod radara javnosti.

\section{4. Izgradnja korporativnog imidža uspostavom Muzeja duhana}

Nakon višegodišnje dvojbe, 1995. godine uprava TDR-a odlučuje se na restauraciju tvorničke zgrade, a proizvodnju seli u Kanfanar. U skladu s izvornom koncepcijom, krenulo se s preuređenjem eksterijera i interijera te podzemnih instalacija. 
Upravni dio je ostao odvojen od proizvodnog, te se u prizemlju postavila muzejska zbirka Tvornice s ciljem predstavljanja njene stogodišnje tradicije. U Radničkom je domu osmišljen prostor za sastanke i ručavanje dok je u unutrašnjem dvorištu izgrađena moderna kuhinja. Proizvodni kompleks je prilagođen zahtjevima tehnološkog procesa tako da uključuje laboratorij i kancelarije. U radove su od samog početka uključeni prof. Marijan Hržić sa Arhitektonskog fakulteta u Zagrebu, prof. Ivo Maroević s Filozofskog fakulteta također u Zagrebu i prof. Vladimir Maleković, ravnatelj Muzeja za umjetnost i obrt (TD magazin 1996: 25-26). Maleković je ujedno autor muzejskog koncepta, o čijoj se realizaciji konkretnije počelo razmišljati nakon promocije knjige Krešimira Džebe Duhanski put (TD magazin 1998: 31). Najranija ideja o osnivanju Muzeja zasigurno se može povezati s kolekcionarskom strašću jednog od djelatnika TDR-a, Franca Kosa, koji je potporu pronašao u liku predsjednika Uprave TDR-a Ante Vlahovića (ibid.). Osim Malekovića, kao autora muzejskog koncepta, dio posla, u smislu prostorne artikulacije Muzeja, obavio je arhitekt Marijan Hržić. ”Muzeološki koncept temeljio se na potrebi da se, nadasve, prikaže 125 godina rada rovinjske tvornice duhana prezentacijom njezinih temeljnih proizvoda, kulturom oblikovanja njihove ambalaže te demonstracijom različitih pribora za pušenje“ (ibid.: 32). Iz muzeološkog koncepta je razvidno da se manje pažnje pridaje sociokulturnoj baštini, odnosno tradiciji radničke klase u liku tabacchina koje su izgradile identitet Tvornice, te se pribjegava konceptu u kojem prevladavaju artefakti vezani isključivo uz proizvodnu djelatnost. U muzeološkoj interpretaciji, korišteni su izvorni dokumenti kao što su radne knjižice i matice zaposlenih, prvotni projekti izgradnje tvorničkih zgrada, arhivski dokumenti koji potiču iz korespondencije Austrijskog državnog monopola, ministarstva financija i rovinjskih lokalnih vlasti, zatim kutije od drveta, lima ili papira za cigare, ručne rezačice, upaljači i različite lule. Izvorni tvornički predmeti su postavljeni u prostor bez društvenopovijesne kontekstualizacije koja bi objasnila kako su ti produkti nastajali. Artefaktima pronađenima u Tvornici autor postava pridružuje četrdesetak izložaka, ponajviše lula, kutija za cigare i cigara, u vlasništvo Muzeja za umjetnost i obrt. "Neke od tih predmeta, primjerice burmutice, datirane su u 18. stoljeću" (ibid.: 33). Ako znamo da je Tvornica utemeljena 1872. godine, jasno je kako ti predmeti nisu u uskoj vezi sa samom povijesti Tvornice. Da je cilj bio ustanoviti Muzej duhana koji bi se bavio poviješću duhanske industrije na prostorima jugoistočne Europe ili barem cijele Hrvatske, tada je 
bilo potrebno obaviti dodatna istraživanja, proširiti koncept i legendama uputiti u osnovne informacije koje nose predmeti. Međutim, znajući da se konceptom težilo prikazati "125 godina rada rovinjske tvornice duhana" takav izbor artefakata i nedostatak muzikoloških pomagala, naracije i kontekstualizacije nisu prihvatljivi. Treći izvor predmeta bio je Austria Tabak Museum u Beču, čiji je ravnatelj sastavio zbirku izložaka koji dokumentiraju razdoblje od utemeljenja Tvornice do I. svjetskog rata. Tvornica duhana Rovinj je najprije bila u vlasništvu Austrijskog državnog monopola, te je ovakva suradnja iznimno važna i zasigurno produktivna te bi kao takva trebala biti primjer ostalim ustanovama u kulturi u Republici Hrvatskoj. Iako je rekognoscirana i građa Zavičajnog muzeja Rovinj, gdje je pronađena izvorna tiskarska preša (oko 1870.) i drveni razboj za izradu tekstilnih traka, ti se predmeti nisu uključili u postav, navodno zbog opsežnik restauratorskih zahvata koji bi bili potrebni i pomanjkanja prostora (ibid.).

Unatoč nedvojbenoj stručnosti autora muzejskog koncepta i prostornih intervencija, čini se da Muzej nikada nije bio u službi društva, nedostajala mu je dublja interpretacija i edukativna komponenta koja bi ga povezala sa zajednicom. Ono što je najvažnije i gotovo nevjerojatno je činjanica da u Muzeju nije bilo gotovo nikakve reference na radnice. Osim knjige radnika otvorene na prvoj stranici na kojoj se evidentira zaposlenje Marie Longo i Marie Devescovi, u Muzeju nisu postojali drugi predmeti, kazivanja, audio zapisi, pa čak ni lijepe fotografije koje smo ranije predstavili, a koji bi sačuvali uspomenu na radničku prošlost i na duboke promjene koje su pogodile Rovinjštinu otvaranjem ovako važnog industrijskog pogona.

Čitanjem internih tvorničkih časopisa tiskanih kasnih 1990-ih, Tvornica duhana Rovinj naglašava svoju društvenu odgovornost koju argumentira stručnom arhitektonskom restauracijom zgrade. Muzej ne dovodi u vezu s društvenom odgovornosti. Prema dosadašnjim razgovorima s nekolicinom Rovinjaca nitko nije znao da je Muzej otvoren ni gdje se točno nalazi. Kao gimnazijalku nikada nas nitko nije uputio ili odveo do tada novootvorenog Muzeja, koji je zaista mogao biti na ponos Rovinjcima, ali i široj javnosti. 
U listopadu 2010. zahvaljujući ljubaznosti Uprave TDR-a posjetila sam Muzej duhana. Gospođe sa porte i tadašnja djelatnica u PR službi uvele su me u prostoriju koja se nalazi u prizemlju djela upravne zgrade. Nisam imala vodstvo, ali ga nisam izričito ni zatražila tako da sam sama razgledala dostupne materijale. Osim očiglednog nedostatka legendi, predmeti su bili vrlo lijepo predstavljeni u staklenim vitrinama i time zaštićeni od vanjskih nepovoljnih utjecaja. Na zidu jedne prostorije bili su izloženi uokvireni nacrti zgrade i poslovna korespondencija vezana uz samo osnivanje Tvornice, dok su se $\mathrm{u}$ drugoj prostoriji nalazile spomenute vitrine, postavljene uzduž dva zida gotovo dosežući strop. Tu su bile izložene spomenute kutije, cigare, rezačice i drugi artefakti vezani uz duhansku proizvodnju, ali nije jasno je li su se te cigare proizvodile $u$ Tvornici ili su one dio neke druge duhanske priče. Tek kada sam pročitala koncept i izvore predmeta, shvatila sam kako su samo neke od tih cigara proizvedene u Tvornici, a ostale su se našle u vitrinama vjerojatno zbog svojih estetskih karakteristika. Kao što je naglašeno, tada se u Muzeju nalazi samo knjiga radnika koja upućuje na postojanje tabacheina.

U kontekstu očuvanja kulturne baštine primjer adekvatno restaurirane, prenamijenjene i očuvane industrijske arhitektonske baštine, svakako je za pohvalu, međutim za muzejsko predstavljanje industrijske materijalne i nematerijalne baštine važno je istraživanje i predstavljanje društveno-povijesnih fenomena koji su omogućavali nastanak takve moćne ekonomije. Pod time mislimo i na kulturne i društvene fenomene u vidu običaja, navika, priča, pjesama, ali i komplesnih identiteta koji se ostvaruju kroz sve navedene prakse.

Kako je Muzej otvoren tako je i zatvoren. Nikada se nije u javnosti mogla pronaći informacija, te je danas s pogledom unazad, jasno kako je Muzej bio lijepa priča za razvoj korporativnog imidža koji je i omogućio prodaju Tvornice. Zgrada u Rovinju je ostala u vlasništvu Adris Grupe te se trenutno profilira kao konferencijski centar. Na temelju profesionalnih poznanstava s kolegama iz Austria tabak Muzeja, kasnije sam saznala da su im predmeti nakon dugo vremena vraćeni. Knjigu radnica sam analizirala po zatvaranju Muzeja te time i mogu posvjedočiti da više nije bila iza stakla muzejske 
vitrine.

Ako promatramo radničke identitete kao dio kulturne baštine zaista je šteta da muzej nije bio javno otvoren za građane s obzirom na vrijednost koju zauzima $u$ lokalnoj povijesti. Legitimno je, s druge strane, da bude internog karaktera jer su zgrada, pa i sama tvornica u privatnom vlasništvu. Međutim, za našu analizu je zanimljivo osvijestiti cilj uspostave ovakvog Muzeja i smjestiti ga u kontekst izgradnje korporativnog imidža TDR-a. Tvornički časopis obiluje 'ljudskim pričama', a njihov se marketinški jezik redovito koristi elementima 'specifične duhanske supkulture' koju oblikuju ljudi. Opisujući promotivni film TDR-a današnji direktor korporativnih komunikacija Adris grupe napisao je: "Naime, u sadržajnom smislu, nipošto se nije željelo slijediti logiku industrijskog filma [istaknuto u originalu], nego, polazeći od kulturološke matrice, tvornicu se pokušava registrirati [istaknuto u originalu] kao važnu adresu hrvatske industrijska arhitekture i, k tomu, kao čimbenika, posvema specifične duhanske (sup)kulture. S pravom, reklo bi se, jer rovinjske tabacchine [istaknuto u originalu] gotovo stoljeće i pol oblikuju socio-kulturni život ovdašnjih ljudi, pa sasvim je izvjesno i njihov svjetopogled" (Grubić 1999: 30).

\section{5. Anketa: Pogledi na rovinjsku industrijsku prošlost}

Da bih istražila kako današnje generacije vide rovinjsku industrijsku prošlost, $u$ kolovozu 2018. godine provela sam online anketu. Spcifičan cilj je bio istražiti da li su mehanizmi prenošenja koji su ranije analizirani utjecali na javno mnijenje. Anketa je poslana na 44 adrese, a odgovor sam dobila od 27 osoba. Anketom sam uključila poznanike koji su bili dostupni online (valjana email adresa i pristup internetu u trenutku istraživanja), a jedini je kriterij bio da su stanovnici Rovinja ili šire okolice, odnosno da su upoznati s općom povijesti Rovinja. Prilikom uzorkovanja, osim ovog specifičnog kriterija, pazila sam da budu jednako zastupljena oba spola, težila sam uključiti građane u dobi od 18 do 70 godina (kriterij: nužnost punoljetnosti i poznavanje rada na računalu), različitih profesionalnih profila i stručnih interesa. Anketa je bila 
otvorena deset dana. Google obrazac mi je omogućio da ispitanici ne mogu vidjeti sljedeće pitanje dok ne odgovore na prethodno, što je bilo važno kako ih sljedeće pitanje ne bi navelo na ono što bi u tom trenutku identificirali kao poželjniji odgovor. Neka su pitanja omogućavala upisivanje slobodnih odgovora $u$ vidu nekoliko riječi koje ih asociraju na određene pojave.

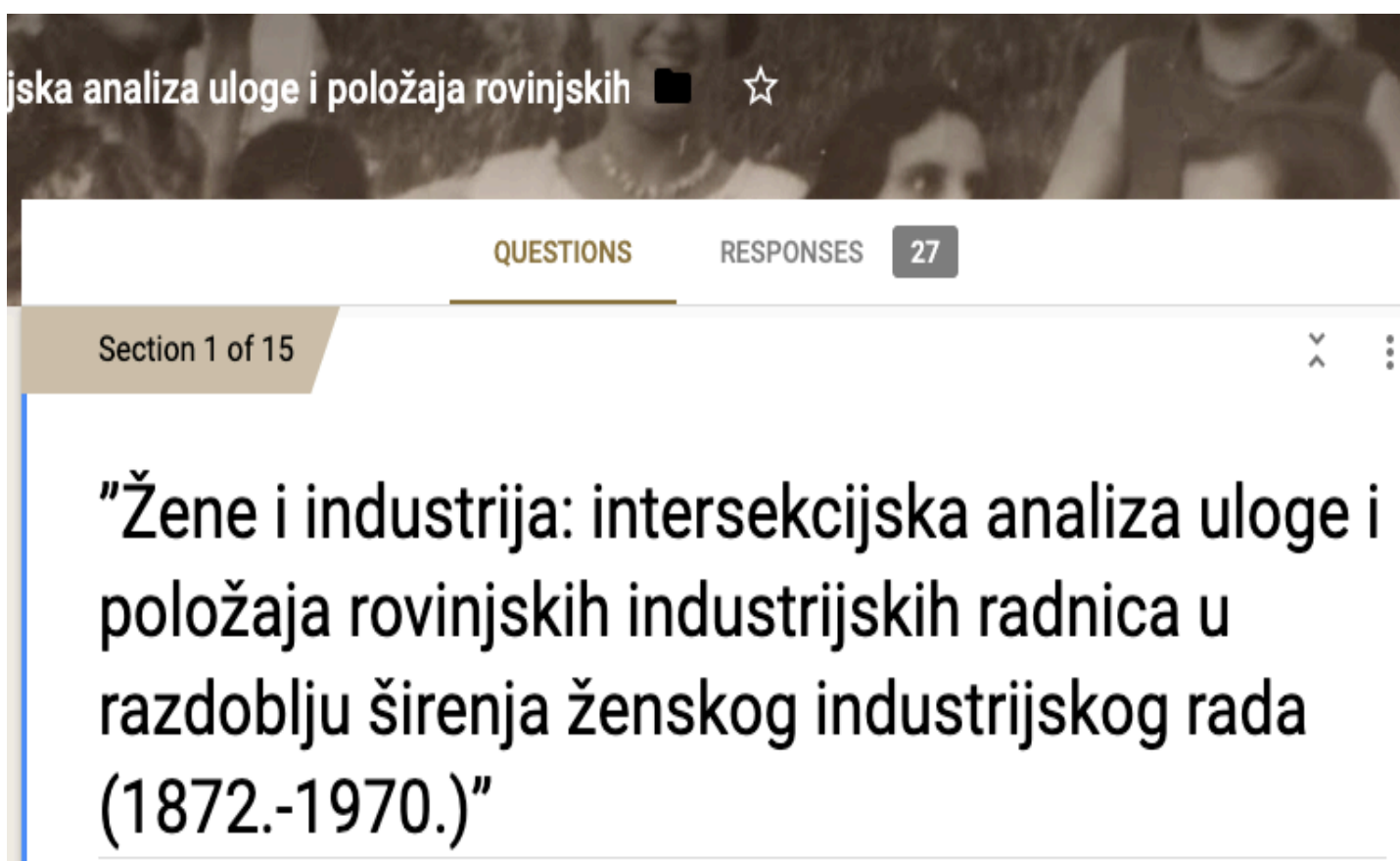

\begin{abstract}
Ovaj upitnik dizajniran je za potrebe izrade doktorske disertacije "Žene i industrija: intersekcijska analiza uloge i položaja rovinjskih industrijskih radnica u razdoblju širenja ženskog industrijskog rada (1872.-1970.)" Tema rada je analiza uloge i položaja industrijskih radnica u Rovinju od osnutka dvaju najvećih tvorničkih pogona, duhanskog i ribljeg, (1872. i 1877.) do kasnih 1970ih g. Definiranim vremenskim okvirom moguće je pratiti značajnije društveno-političke (Austro-Ugarska, Kraljevina Italija i SFRJ) i tehnološke (od manufaktura do suvremene mehanizacije) promjene s reperkusijama na društveni položaj radnica. Intersekcijskom analizom povijesnih izvora o statusu radnica krajem 19. i početkom 20. stoljeća i življenih iskustva radnica koja predstavljaju empirijski dio kvalitativnog etnografskog istraživanja, radom će se istražiti razlozi nevidljivosti ženskog rada u ranoj fazi industrijalizacije te mehanizmi tvorbe i presijecanja različitih identiteta unutar radničke grupe. Naglasak istraživanja bit će na artikulaciji heterogenosti radničkih iskustava, posebno na razini interpretacije (društvenog) sjećanja nasuprot življenog iskustva.

Cilj upitnika je kroz jasno strukturirana pitanja i ograničene odgovore mapirati opća mjesta društvenog sjećanja na radnice u formativnom razdoblju rovinjske industrijalizacije. Podaci dobiveni upitnikom usporedit će se sa življenim iskustvima prikupljenim polustrukturiranim intervjuima i podacima dobivenim analizom dostupnih povijesnih izvora (rovinjske Matične knjige stanja duša, rođenih, vjenčanih i umrlih, Statut Grada Rovinja-Rovigno, Knjiga radnica TDRa iz 1872.).

- Sudjelovanjem u anketi pristaješ na korištenje podataka navedenih u obrascu isključivo za potrebe doktorske disertacije "Žene i industrija: intersekcijska analiza uloge i položaja rovinjskih industrijskih radnica u razdoblju širenja ženskog industrijskog rada (1872.-1970.)" autorice Tamare Nikolić Đerić u sklopu Poslijediplomskog doktorskog studija na Odsjeku za etnologiju i kulturnu antropologiju Filozofskog fakulteta u Zagrebu.

- Na samom kraju obrazac nudi mogućnost anonimnog sudjelovanja

- Sva pitanja se odnose na period tretiran doktorskom disertacijom (1872. TDR/ 1877. Mirna-1970.),
\end{abstract}

Unaprijed zahvaljujem na sudjelovanju koje će uvelike doprinijeti kvaliteti rada.

Slika 22. Naslovna stranica online upitnika 
Prva tri pitanja općeg su karaktera te nas informiraju u strukturi ispitanika. Od 27 ispitanika 25,9\% su muškarci, a 74,1\% žene. Iako slabo zastupljeni, mlađi od 25 godina zauzimaju ipak značajnih 3,7\% ispitanika, osobe u dobi od 25 do 50 godina čine $77,8 \%$ ispitanika, dok su stariji od 50 godina zastupljeni s 18,5\%. Takav rezultat uvjetovan je nejednakim uzorkovanjem. Zastupljenije su osobe starosti bliže mojoj generaciji zbog toga što je upitnik poslan uglavnom mojim poznanicima koji pripadaju toj dobnoj skupini. Ono što je važno naglasiti kada je u pitanju generacijska zastupljenost jest da sam u proljeće 2018. godine o temi disertacije govorila u sklopu nastave Hrvatske kulturne baštine u Srednjoj školi Eugen Kumičić u Rovinju, čime sam ovu važnu temu uspjela približiti rovinjskoj mladeži. Potaknuta tim predavanjem, jedna je učenica završni rad odlučila pisati upravo na temu rovinjskih radnica. 88,9\% ispitanika su zaposlenici, 7,4\% su umirovljenici, te 3,7\% studenti.

Prvo pitanje usmjereno na adresiranje teme željelo je ispitati jesu li pojmovi tabacchine i sardelline uopće bliski i poznati javnosti. Iz donjeg grafikona vidimo da 92,6\% ispitanika prepoznaje pojam tabacchina, nešto manje, ali zadovoljavajućih $74,1 \%$ ispitanika prepoznaje pojam sardellina. Dvije osobe, odnosno 7,4\% ispitanika nisu nikada čuli za te termine.

Označi pojam/ pojmove koji su ti poznati 27 responses

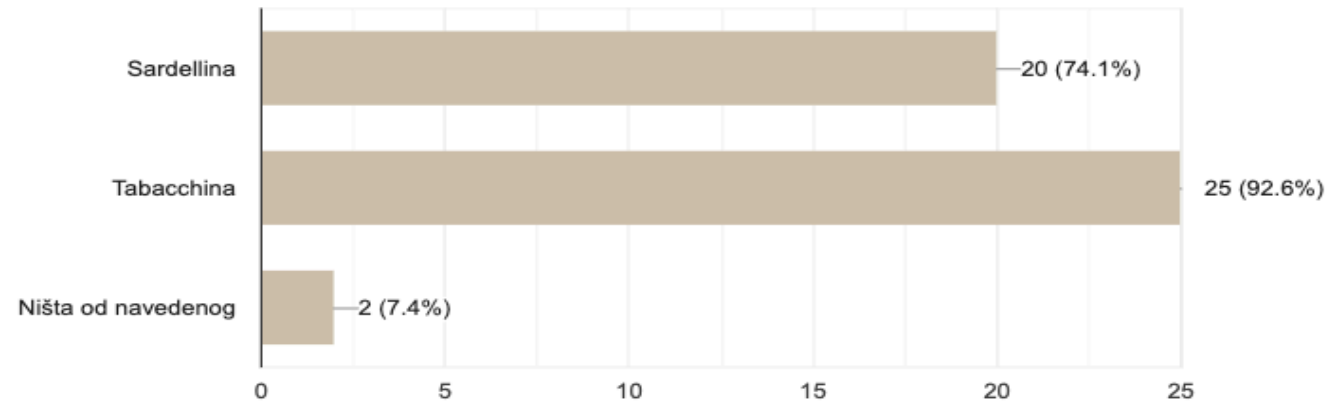

Grafikon 1 
Ako su prepoznali termin, od ispitanika sam tražila da navedu jesu li sjećanja ili stavovi koje povezuju s tim pojmom pozitivni ili negativni. Osim 7,4\% ispitanika koji nemaju stav, ostalih $92,6 \%$ uz pojam tabacchine veže isključivo pozitivna sjećanja i stavove. Kada govorimo o sardellinama, rezultati su nešto lošiji. $18,5 \%$ nema stav o sjećanju na sardelline, što možemo tumačiti kao nepoznavanje termina ili vrlo loše poznavanje termina, a 77,8\% ispitanika ima pozitivan stav, dok $3,7 \%$ ima negativan stav prema tim pojmovima.

\section{Kakva sjećanja/stavove u tebi budi riječ Tabacchina}

27 responses
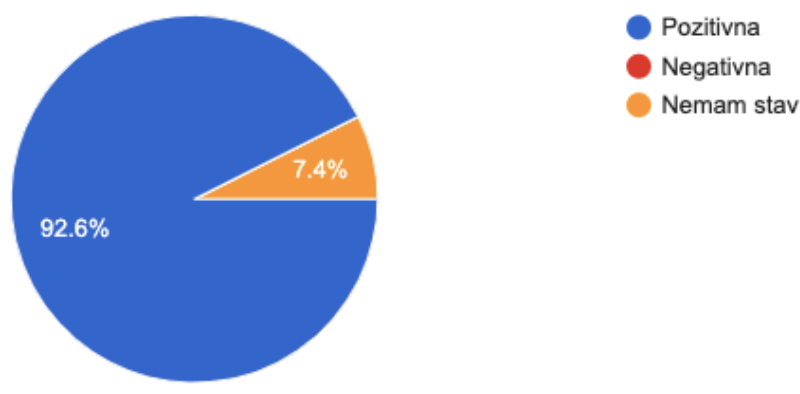

Kakva sjećanja/stavove u tebi budi riječ Sardellina

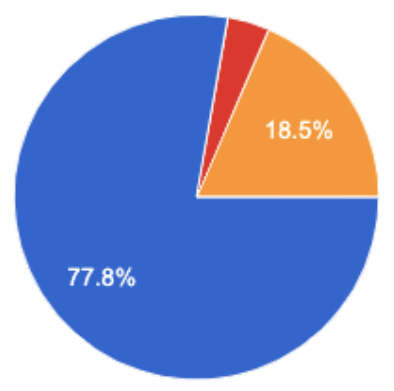


Slijedilo je pitanje vezano uz asocijacije uz pojam tabacchina, na koje je odgovorilo svih 27 ispitanika. Od toga dvije osobe kao prvu asocijaciju, dakako, spominju duhan, odnosno tabak, drugi različitim rječnikom navode asocijaciju na radnice, odnosno žene, a zanimljivo je da nailazimo i na prestiž kao asocijaciju, te $\mathrm{s}$ jedne strane smrad, a s druge miris friškog tabaka (duhana). Ovakvi nas rezultati navode na razmišljanje o društvenoj konstrukciji recepcije mirisa. Ono što se u nekom povijesnom periodu doživljava kao poželjan miris, u drugom može biti percipirano izrazito negativno. Antipušačke kampanje zasigurno su pridonijele takvom stavu, a pitanje je i koliko će utjecati i na pamćenje tabacchina kao uzornih i prestižnih radnica.

Pojam sardelline u našem kontekstu označava žene koje rade u Tvornici za preradu ribe. Ispitanici u najvećem postotku doslovno navode male srdele ili srdele kao asocijaciju, no ima i odgovora koji pod tim pojmom pomišljaju na žene u procesu prerade ribe. 7,4\%, dakle dva ista odgovora (koji se nažalost ovdje ne vide, no dostupni su u detaljnijoj analizi), sardelline povezuju sa smradom, odnosno za dvoje je ljudi to prva asocijacija. Nakon analize upitnika uvidjela sam da nisam najbolje sročila pitanje jer je najlogičniji odgovor bio asocijacija na ribu odnosno duhan. U svakom slučaju, raznolikost odgovora je zadovoljavajuća i smatram da su pokrivene sve asocijacije koje sam ranije spominjala.

Misliš li da su Tabacchine (radnice Tvornice duhana Rovinj) i Sardelline (radnice Tvornice za preradu ribe Mirna) imale jednake uvjete rada kao i muškarci na istim pozicijama?

27 responses

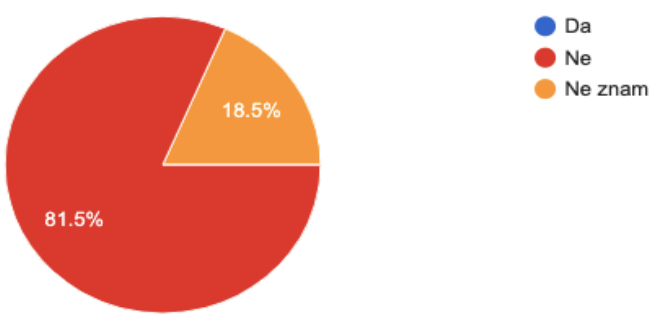

Grafikon 4 
Na pitanje jesu li žene u navedenim industrijama imale jednake uvjete rada kao i muškarci na istim pozicijama, odgovaraju svi ispitanici. 81,5\% ispitanika smatra da muškarci i žene nisu imali jednake uvjete rada, dok njih 18,5\% odgovara s "ne znam". Ovakav odgovor možemo tumačiti dobrim poznavanjem povijesti industrijalizacije Rovinja ili projiciranjem suvremenih nejednakosti (u poslovnom okruženju) na prošlost. $\mathrm{S}$ obzirom na šturost podataka o industrijskoj povijesti Hrvatske ili Rovinja $u$ popularnoj literaturi, školskim kurikulima, lokalnim muzejskim postavima i drugim medijima, vjerojatnije je ovo potonje. Posebno je zanimljivo da su, unatoč nedvojbenoj rodnoj diskriminaciji i subordiniranoj poziciji koju ispitanici osvještavaju kod konkretnog pitanja uvjeta rada, njihova sjećanja, sudeći prema prethodnim odgovorima, uglavnom pozitivna. Ovakva se situacija može povezati s konceptom selektivnog sjećanja. Radnice, ali i ispitanici, odnosno šira javnost, svojim sjećanjem konstituiraju društveno pamćenje. Isto se postiže procesima selekcije isključivo pozitivnih elemenata industrijskog rada. Da je tome tako, pokazat će i odgovori koji slijede.

\section{Da li misliš da su Tabacchine imale dobre uvjete rada?}

\section{7 responses}

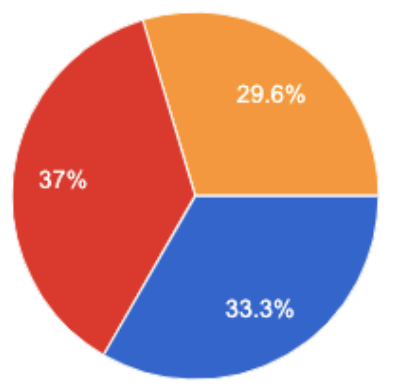

$$
\begin{aligned}
& \mathrm{Da} \\
& \mathrm{Ne} \\
& \mathrm{Ne} \text { znam }
\end{aligned}
$$

\section{Grafikon 5}

Nastavno na raniji komentar, primijetit ćemo da ispitanici nemaju jasan stav o uvjetima rada. Odgovori su podijeljeni gotovo podjednako. $37 \%$ ispitanika smatra da uvjeti nisu bili dobri, njih 33,3\% smatra da su uvjeti rada u promatranom periodu bili dobri, a njih $29,6 \%$ ne zna. 
Da li misliš da su Sardelline imale dobre uvjete rada?

27 responses
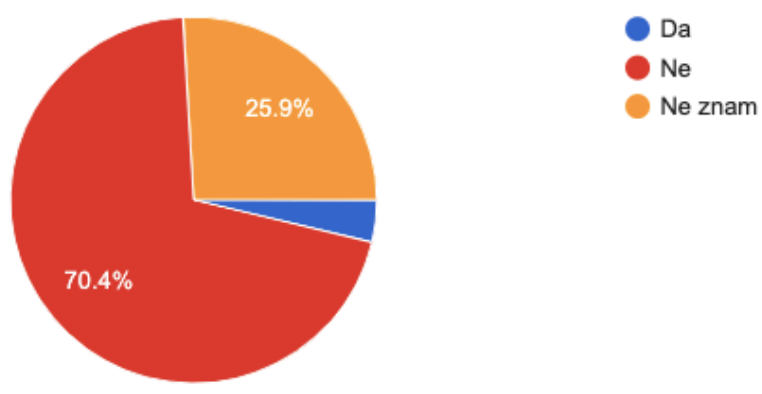

Ne znam

Grafikon 6

Kada govorimo o uvjetima rada sardellina, 70,4\% ispitanika smatra da uvjeti rada nisu bili dobri. Njih 25,9\% nema stav, a 3,7\% smatra da su uvjeti bili dobri.

U kojem su pogonu, prema tvom mišljenu, uvjeti rada bili teži?

27 responses

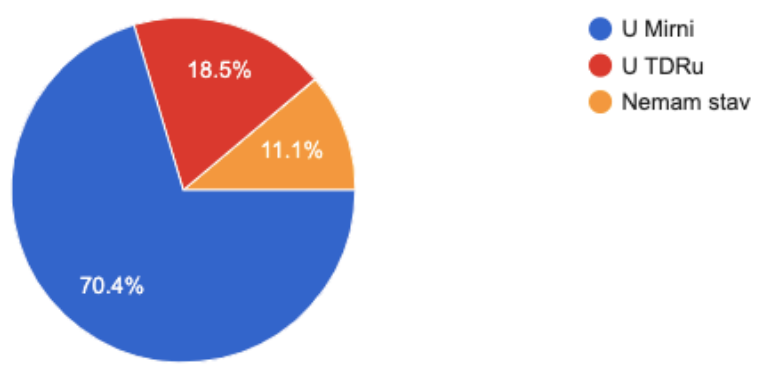

Grafikon 7

Nakon generičkih pitanja o uvjetima rada u oba pogona, ispitanike sam zamolila da u nekoliko riječi objasne svoj stav. 
Odgovori koji su se ticali uvjeta rada u Tvornici duhana Rovinj uključuju slijedeća objašnjenja: nesigurna plaća, hladnoća, smrad, konstantno rad u vodi, uvijek ruke u mokrom ledu i vodi, loši odnosi nadređenih prema radnicama, prerada ribe obuhvaćala je rad u hladnoj vodi, stajanje u istom položaju dugo vrijeme, radile su uvijek rukama u vodi i ledu, rukama su uvijek bile u vodi i ledu, loš odnos nadređenih prema njima, ovisile su o uplovi ribarica s ribom, bilo je više faza prije konzerviranja ribe, cijela tvornica je "mirisala" po ribi, a tako su mirisale i same radnice, izgleda mi da je teže raditi s ribama i u mom gradu su nas strašili ako budeš zločest i neuspješan raditi ćeš u tvornici riba, a s tabakom nismo imali veze, miris, možda je obrada ribe bila zahtjevnija, mislim da je obrada ribe te čišćenje puno teži bili, čistile su ribu, imale su neprestano ruke u hladnoj vodi, osim teškog rada jednih i drugih, u Mirni su još i bile u hladnom i mokre cijeli dan, smrad, manji uvjeti rada, jer je teže i danas raditi s ribom nego s duhanom, životinjama nego s biljkama, vlaga, prerada ribe radila se dugo ručno, u hladnoj vodi, neugodnim mirisima i sl.

Većina ispitanika smatra da je posao u Tvornici duhana bio jednostavniji, međutim ima i onih koji su uvjete rada povezivali direktno sa zdravstevnim stanjem, navodeći: tabak ubia, teže je bilo u TDR-u zbog nikotina, opasnije je bilo za zdravlje raditi u fabriki tabaka, ne znam, sjećam se Lenke, pjesme Koče Racina... Umrla je radeći $s$ duhanom... znam jako malo o tom vremenu, ali općenito (ne samo za žene), čini mi se da su uvjeti rada u TDRu bili teži radi nedostatka moderne mehanizacije i higijenskih uvjeta rada.

Kroz disertaciju sam više puta propitivala ideju emancipacije kroz (plaćeni) rad te nastojala pokazati da je plaćeni rad, u ovom slučaju industrijski, samo dio emancipacijskog potencijala žena. Osim mogućnosti da se zaposli i privređuje, žena puni emancipacijski potencijal plaćenim radom ostvaruje u trenutku kada svojim novcem raspolaže onako kako želi, odnosno da radi i zarađuje za sebe, a ne, kao što su često opisivale kazivačice, isključivo za druge. Kazivačice su uglavnom isticale teške životne uvjete, u kojima poljoprivredna i ribarska djelatnost nisu mogle zadovoljiti osnovne potrebe jedne rovinjske obitelji. Žene su svoj novac koristile kako bi prehranile obitelj. Međutim, pritom su postale dvostruko, a neke i trostruko opterećene. Osim u 
tvornici, neke su radile u vlastitom polju pomažući suprugu, druge su nadničarile u tuđim poljima da bi prehranile djecu (tvornička plaća nije bila dovoljna), a sve su bez iznimke bile odgovorne za kućanske poslove, odgoj djece i brigu o starcima. U vrijeme dok su naše sugovornice bile u radnom odnosu, muškarci su uglavnom bili oslobođeni kućanskog rada, a mnogi su vrijeme, sudeći prema pojedinim kazivanjima, provodili u lokalnim krčmama. Ako sagledamo rezultate Izvještaja Eurobarometra koji se navodi u uvodu ovog rada, vidjet ćemo da se situacija nije bitno promijenila; unatoč jednakim obrazovnim prilikama (u europskom kontekstu) i plaćenom radu dostupnom velikoj većini žena, nejednakost je prisutna i danas, a ogleda se prije svega u nejednakoj plaći za isti posao, manjku slobodnog vremena, brizi o bližnjima, te odsustvu žena s pozicija moći (političke i financijske). U tvornicama su kroz istraživani stoljetni period bez iznimke direktori i kontrolori bili muškarci. Poučeni intersekcijskom analizom, dodajmo i to da su u velikoj mjeri bili stranci. Danas TDR posluje pod okriljem British American Tobaccoa, direktor je stranac, a vodeći menadžment tvrtke na globalnoj razini sastavljen je od jedanaest muškaraca i dviju žena (izvor: bat.com).

Sve navedeno - povijesni presjek, etnološko istraživanje i provedeno anketno istraživanje - potvrđuje suštinsku nepromijenjenost pozicije žena na tržištu rada, ali i u svakodnevnom životu. Međutim, radnice i ispitanice gotovo bez iznimke industrijski rad povezuju s emancipacijom.

Da li smatraš da je industrijski rad doprinio emancipaciji žena (na konkretnom rovinjskom primjeru)?

27 responses
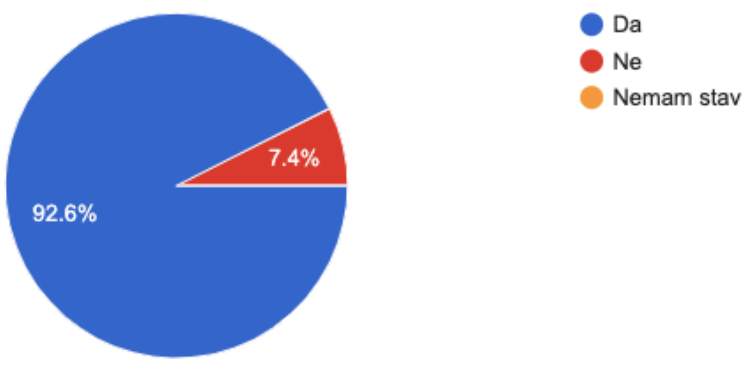

Grafikon 8 
Prisjetimo li se Charlotte Gilman Perkins, otvorit će nam se esencijalistička perspektiva kojoj nisam sklona, ali koju valja podastrijeti. Perpetuiranim mehanizmima subordinacije, koji se kreću od isključivanja iz javnih spisa do označavanja ženskog rada kao nevještog, stoga i manje vrijednog, žena kao da je uvjerena da su sve zadaće njezine. Prihvaćanjem subordinirane pozicije u najrazličitijim životnim okolnostima, žene u industriji postaju, da se izrazim slikovito, slične osobama koje žive pored tramvajske pruge i nakon nekoliko dana, mjeseci i godina ne čuju ni zvuk tramvaja niti osjećaju podrhtavanje poda.

\section{ZAKLJUČAK}

Krajem 19. stoljeća Rovinj postaje jedan od razvijenijih industrijskih gradova u Istri. Specifičnost rovinjske industrije počiva na činjenici da se kvantitativno temeljila na ženskom radu. Ta je činjenica određenom broju radnica u duhanskoj industriji omogućavala bolji društveni status, a naznake za potvrdu ove teze nalazimo $u$ povijesnim pisanim izvorima koji ih od kraja 19. stoljeća, konkretnije 1888. godine uključuju u javni diskurs (Benussi 2004 [1888]). Sve dotad Rovinjke su se u povijesnim radovima i javnim spisima spominjale tek sporedno. Posebno je nevidljiva njihova poslovna sposobnost, koja je uvjetovala i društveni status. Razvojem industrije i sve većim brojem žena koje radnički u njoj sudjeluju, njihova se vidljivost donekle povećava, no kao što se pokazuje u ovom radu, nedovoljno s obzirom na njihovu brojnost i društvenu ulogu u razvoju industrije, ali i grada Rovinja. Stoga sam nastojala ukazati na konkretne primjere nevidljivosti rovinjskih radnica $u$ javnim spisima $i$ povijesnim radovima, a rodno osviještenom analizom pokušala sam otkriti razloge takve nevidljivosti. Kao svojevrsni kontrapunkt navedenom, a polazeći od rijetkih no ipak važnih povijesnih izvora u kojem se spominju radnice te primjenom etnografske metode polustrukturiranog intervjua s bivšim radnicama dviju rovinjskih tvornica, $\mathrm{u}$ radu prikazala bogatstvo, ali i heterogenost njihovih radničkih iskustava. Posebno sam se pritom usredotočila na odnos življenih iskustava i individualnih sjećanja u odnosu na kolektivno (društveno i kulturno) pamćenje. 
Da bih se bavila ženskom temom iz feminističke perspektive u svom rodnom gradu, najprije sam kroz prizmu feminističke antropologije otvorila pitanja insajderskog istraživanja, a zatim i objektivnosti istraživača. Za razumijevanje tih pitanja koristila sam koncept autokulturne defamilijarizacije (Gulin Zrnić), a zatim i koncept koji uključuje zahtjev za odmakom od klasičnog etnografskog kanona, a koji je predstavljen istraživanjem po osi "drugi-drugdje-drugačiji” u "drugi-ovdje-drugačiji” (Potkonjak). Gulin Zrnić je u svojem istraživanju zaključila da se na specifičnom primjeru svakodnevice urbane kulture novozagrebačkog naselja isprepliću karakteristike domaćeg terena i zahtjevi auto-antropologije, s obzirom na to da znanstvenica ne samo da istražuje na domaćem terenu (u svom naselju) već i dijeli simbolički prostor (sudjeluje u stvaranju zajednice) istraživanja s ispitanicima. Međutim, ta "čista" insajderska i auto-antropološka pozicija u praksi nije funkcionirala u potpunosti.

Usporedivši tu poziciju sa svojom vlastitom uvidjela sam da je moj "domaći” teren, konstituiran gotovo isključivo geografskim odrednicama, vremenom poprima obilježja dalekog i stranog. Tome su doprinijeli intersubjektivni odnosi među kazivačicama, generacijski jaz između mene kao istraživačice i kazivača, te moja akademska pozicija. Potpuna identifikacija s domaćim terenom nije bila moguća.

Nemogućnosti poistovjećivanja s domaćom istraživanom zajednicom usporedila sam s pisanjima dr.sc. Jasna Čapo Žmegač na temelju istraživanja prisilnih migracija srijemskih Hrvata (v. Čapo Žmegač 2006). U toj nemogućnosti kao temeljni problem analogijom prepoznajem pitanje zauzimanja pozicije (one advokata ili analitičara) te pitanje lojalnosti u samom procesu zauzimanja jedne od navedenih pozicija i kasnije, u procesima restituiranja istraživanja istraživanoj zajednici. Na primjeru istraživanja uloge i položaja rovinjskih radnica, nameće se zaključak da s obzirom da je "čisto" definiranje pozicije moguće samo ako etnolog-istraživač istražuje temu kojoj je privržen i za koju osjeća određenu emotivnu vezanost te joj pristupa iz aktivističke pozicije. U svim ostalim insajdersko-istraživačkim kontekstima zbog identitetne polimorfnosti etnologa (v. Narayan 1993) vjerojatnija je hibridnost pozicija. Zaključak možemo proširiti i reći da je tek kada istražujemo intelektualno i emotivno "bliska" mjesta, neovisno o geografskoj lokaciji, nužnost auto-antropologije neupitna, posebno ako je 
shvaćamo kao "istraživanje u kojem istraživač i istraživana grupa dijele premise o društvenom životu koje oblikuju antropološko pitanje” (v. Strathern 1987).

Iako problematika metodologije insajderskog terena nije bila planirana kao jedno od istraživačkih pitanja, istraživački proces je nametnuo ovu temu kao jednu od ključnih. Razlog tomu je propitivanje ženskih radničkih iskustava unutar zajednice kojoj kao žena i radnica pripadam, a što neizbježno utječe na sam proces istraživanja $i$ na interpretaciju istraživanja. Iscrpno navođenje dosadašnjih dostignuća na polju metodologije i epistemologije terenskog rada, upotpunila sam vlastitim iskustvom koje karakterizira specifičnost odnosa na relaciji kazivač-istraživač i kazivač-kazivač. Iskustvo koje sam ovim istraživanjem doživjela i artikulirala kroz prizmu etnografije i kao metode i kao metodologije, posebice ako teren ne promatramo kao geografsku već iskustvenu odrednicu, smatram vrijednim doprinosom unaprjeđivanju insajderskog terenskog rada u domaćim okvirima spomenute rasprave o pisanju o domaćem terenu.

Definiranim teoretsko-metodološkim okvirom i polazeći od pretpostavke da je ženska poslovna aktivnost nevidljiva kroz povijest ne bi li se tako potvrdila i održala njihova sekundarna pozicija u društvu, najprije sam analizirala relevantne povijesne izvore. S obzirom na činjenicu da se društveni položaj osobe uglavnom određivao u odnosu na njegovo/njezino zanimanje i plemićku titulu, analizirala sam jesu li se i u kojim situacijama upisivali podaci o ženskim zanimanjima. Analizirani su izvori koji se tiču Rovinja, s posebnim fokusom na upise o ženama tijekom 19. stoljeća. Povijesna istraživanja koja dovodim u korelaciju, dokazuju da u predindustrijsko vrijeme žene učestalo rade jednake poslove kao i muškarci, no njihov rad ostaje javno prešućen. "Javnost" u ovom smislu predstavljaju matični spisi. Dugotrajnost takve prakse utjecala je na sekundarnu poziciju žena na tržištu rada i s početkom industrijalizacije.

Usporedivši znanstvene radove koji istražuju poziciju žena kroz povijest, posebno one Marije Mogorović Crljenko, s primarnim povijesnim izvorima (javni spisi poput Statuta Rovinja, matičnih knjiga i Knjige radnica Tvornice duhana Rovinj), potvrdila sam pretpostavku o nevidljivosti ženske poslovne sposobnosti, odnosno činjenicu da se u navedenim dokumentima gotovo ne spominju ženska zanimanja ni 
njihov poslovni, kućanski ili obiteljski status. Žene su radile u kući, ali i kao podrška, ako ne i jednako, muškarcima u polju ili obrtu. Međutim, njihov se rad nije smatrao radom, već se profesija pripisivala muškarcu. Dodatno, kako će brojne autorice primijetiti (Gilman 2012; Federici 1975 i dr.), neplaćeni rad nikada nije bio javno priznat, a kao takav ni društveno relevantan. Za razliku od toga, muškarcima su se rad u poljoprivredi i/ili ribarstvu za vlastite potrebe, kao i ekonomija temeljena na trampi društveno priznavali i pozitivno valorizirali. Analiza je pokazala da se upravo u toj tradicijsko patrijarhalnoj pravnoj strategiji krije dio ženske podređenosti kroz stoljeća. U prilog tome govori i činjenica da su se unatoč industrijalizaciji konceptualni okviri javnih spisa na konkretnom primjeru rovinjske zajednice sporo mijenjali.

Nadalje, analizom matičnih knjiga fokusirala sam se na promjene koje se na razini konceptualizacije i vođenja knjiga dešavaju s razvojem industrije. U stoljećima vođenja matičnih knjiga, žensko zanimanje spominje se samo iznimno i to isključivo kod primalja. Tome je tako ne zbog činjenice što im je to zanimanje omogućavalo ravnopravni društveni status s muškarcima, nego zato što su one bile svjedokinje prilikom rođenja, čedomorstva i slično, barem kada je riječ o javnim pravnim spisima. Osim primalja, iznimno se spominje zanimanje učiteljice i to tek sredinom 19. stoljeća. Posebno je poražavajuće da se do 1890. godine u knjigama krštenja/rođenja ne spominje status majke, ali je on, primjerice, predviđen za knjigu umrlih. Međutim, iako je predviđen, taj se podatak sve do 1913. godine za žene nije upisivao.

Za ovaj su rad posebno korisne knjige vjenčanih. U njima je od 1859. predviđena rubrika zanimanja za žene, međutim sve do 1906. godine u nju se upisuju podaci o očevom zanimanju. Ako znamo da od 1872. godine, a analizom smo pokazali i ranije slučajeve, Rovinjem "vlada" ženski javni rad jer 97\% radne snage najvećeg tvorničkog pogona čine žene, te da se njima pet godina kasnije pridružuje najmanje 120 žena iz Tvornice za preradu ribe, 34-godišnje izostavljanje žena iz rubrike conditio čini dobre temelje za dokazivanje teze o nevidljivosti poslovne aktivnosti žena u javnim spisima kao posljedici androcentričnih strategija održavanja moći. Problem se dodatno usložnjava kada podatke analiziramo primjenom intersekcionalizma, kojim sam nastojala ukazati na nejednak položaj radnica. 
Iz matične knjige i knjige radnica primijetili smo da su se u Tvornici zapošljavale uglavnom Rovinjke. U ranoj fazi rada tvornice, nacionalna diversifikacija unutar radnog kolektiva nije toliko prisutna. Međutim, činjenica da su sve sluškinje došljakinje, a Rovinjke industrijske radnice, doprinosi shvaćanju nejednakog položaja i uloga radnica temeljem nekoliko distinktivnih karakteristika, poput nacionalnosti, klase i tjelesnosti kojom obuhvaćamo i jezik. Takva se distinkcija u narednim periodima sve više ističe, na što prije svega utječu snažne migracije i miješanje stanovništva uzrokovano industrijalizacijom, promjene upravljačkih struktura, te makroekonomske i političke prilike. Da razvoj industrije u određenoj mjeri utječe na povoljniji društveni status žena u Rovinju, vidljivo je i iz povijesnih javnih spisa. Konkretno, brojnost ženske radne snage u kontekstu industrijalizacije koja je državama donosila moć omogućava uključivanje žena u javni diskurs. Bilo je nemoguće sakriti tu radnu snagu s obzirom na profit koji je državi nosio. Takvi su se uspjesi valjali bilježiti i kontrolirati. Isto se provodi kroz matične knjige i radničkom evidencijom. To je prvi korak u osvještavanju i priznavanju ženskog rada, no važno je naglasiti da je priznanje radničke pozicije ženama bilo omogućeno tek kroz plaćeni industrijski rad, dok je sav ostali ženski javni ili privatni rad ostao i dalje nevidljiv. Kako u pitanju emancipacije i subordinacije ništa nije jednosmisleno i jednostavno, posebno je značajno uočiti uvođenje rubrike "status-conditio" za žene 1859. godine, na samom početku industrijalizacije, a time i činjenicu da se uzus upisivanja očevog zanimanja nije mogao iskorijeniti naredne 34 godine unatoč aktivnom radu žena. Ovakva praksa može ukazivati na političku volju i u tom kontekstu nužnost uključivanja žena u javni sektor, no na praktičnoj, svakodnevnoj razini gdje su se patrijarhalni odnosi teže mijenjali vidimo da se status žena mijenjao sporo.

Veliki dio istraživanja podrazumijevao je terenski rad polustrukturiranim intervjuom s radnicama ili potomcima radnica. Primjena intersekcijske analize $\mathrm{s}$ fokusom na življena iskustva, individualna sjećanja i kulturno pamćenje o radnicama pokazala je mehanizme formiranja hegemonijskih odnosa unutar radničke klase temeljenih na distinktivnim karakteristikama poput roda, klase, nacionalnosti i tjelesnih dispozicija. Period koji je obuhvaćen sjećanjima seže u razdoblje između dva rata, a življena su se iskustva uglavnom realizirala u periodu od 1948. do 1970. godine. 
Intersekcijska se analiza sada proširuje na druge distinktivne elemente koje kroz povijesne spise nije bilo moguće potvrditi. Saznanja koja smo utvrdili iz pisanih izvora o najranijoj tvorničkoj prošlosti, upotpunjena su kazivanjima o vlastitim radničkim iskustvima i sjećanjima na članice obitelji koje su radile u tvorničkim pogonima, najčešće majke i bake, ali nerijetko tetke i prabake.

Temeljem provedenog istraživanja, moguće je zaključiti da su žene su Rovinju imale povoljan društveni položaj i prije same industrijalizacije. Tomu je tako jer stoljećima uživaju mogućnost jednakog upravljanja imovinom i nasljeđivanja, što se ženama, primjerice u drugim hrvatskim sredinama pravno omogućava tek ustavom iz 1946. godine, kada se prava muškaraca i žena izjednačavaju. Kazivači bez iznimke smatraju da su i u daljoj prošlosti svi radili i da se na žene nikada zbog toga nije lošije ili bolje gledalo. Jednako se tako slažu da se njihov položaj ipak mijenja od uspostave tvornica, te postaje povoljniji. Radnice tvornice duhana su jedine, uz iznimku uprave i administracije, kojima je plaća osigurana. Ta ih činjenica od najranijih dana postojanja tvornice izdvaja ne samo u odnosu na većinu sugrađana već i u odnosu na druge, prekarne, industrijske radnice potvrđujući tezu da stabilna ekonomska neovisnost doprinosi ženskoj emancipaciji. Ta je emancipacija još uvijek u okvirima patrijarhalnih odnosa te ekonomska stabilnost mijenja društvene odnose u onoj mjeri u kojoj se sada ženska djeca lakše osamostaljuju, u mogućnosti su same prirediti bogat miraz, a kasnije osiguravati sredstva za život za dobar dio obitelji. Plaćenim javnim radom manjem je broju žena omogućeno političko djelovanje svedeno na podržavanja radničkih štrajkova, a drugima sportsko-rekreativno ili kulturno provođenje slobodnog vremena. Ipak, to nije realnost svake radnice. Kvaliteta intersekcijske analize se ogleda upravo u izbjegavanju homogenizacije iskustava i pokušaja uočavanja obrazaca po kojima se realizira društvena nejednakost. Istraživanje je pokazalo da društveni položaj radnica ovisi o brojnim faktorima, poput nacionalnosti, profesionalnog statusa, bračne veze, klase i tjelesnosti. Stoga se stupanj emancipacije određuje kada se svi ovi faktori uzmu u obzir, te se u odnosu na njih radnička iskustva realiziraju i percipiraju na različite načine. 
S obzirom na navedeno, istraživanje pokazuje da su u najranijem periodu industrijalizacije, pa sve do kasnih 1940-ih, najbolji položaj imale radnice tvornice duhana rovinjskog podrijetla koje su radile na poziciji maestre, odnosno učiteljice i koje nisu bile maloljetne, te koje su uz sve navedeno dolazile iz obitelji poljoprivrednika, trgovaca ili obrtnika, odnosno kojima su supružnici osiguravali dodatne izvore za život. Uz obiteljsku potporu, koja se ogledala u imovini (polja, kuće, životinje) i pomoći u kućanskim poslovima i oko djece, takve su se radnice mogle posvetiti i slobodnim aktivnostima i nisu bile toliko fizički opterećene. Slobodne djevojke su u tom smislu bile u još povoljnijem položaju, te pritom zbog aktivnog života nisu osuđivane od društva. Zanimljivo je da su brojne radnice ostale neudane ili da su godinama živjele s izvanbračnim djetetom pa su se tada preudale. Ovakve odluke su najbolji odraz položaja koji su radnice tvornice duhana mogle ostvariti, posebno u vrijeme kada je muškarac imao isključivo pravo na djecu. Nešto nižu poziciju su imale tabacchine udane za ribara jer je njihova plaća bila gotovo jedini stalni izvor prihoda. Konkretne podatke za sardelline na prijelazu stoljeća nemamo osim što znamo da je njihova plaća bila nestalna, pa je moguće analogijom pretpostaviti da su one $u$ tom nizu bile na posljednjem mjestu. Jedino u slučaju da su dolazile iz bogatije obitelji njihov bi status bio povoljniji, no to nije bio slučaj ni kod jednog kazivanja. Dodajmo k tome da se rad u ribljoj industriji zbog loših uvjeta rada uvijek smatrao manje dostojnim, te se takvi stereotipi prenose do danas.

Razvojem industrije, etnička struktura stanovništva i radništva se mijenja, posebno nakon Prvog svjetskog rata. Ta 'transformacija' se dešava postepeno i traje u periodu međuraća. U grad dolaze djevojke slavenskog podrijetla, uglavnom iz obližnjih mjesta, te se položaj radnica percipira u odnosu na industriju u kojoj su zaposlene, a kojoj pridonosi snažna diskriminacija temeljena na nacionalnosti i političkom opredjeljenju prilikom zapošljavanja. Takva politika zapošljavanja došljakinje automatizmom stavlja u podređenu poziciju omogućavajući im samo poslove s lošijim uvjetima rada i nestalnim plaćama. Unatoč tomu, sve kazivačice potvrđuju da je rad u tvornicama predstavljao nove mogućnosti, posebno u vidu samostalnog života, odabira bračnog supružnika i jednak status unutar obitelji. Isto vrijedi za radnice u oba pogona i obje nacionalnosti. Opterećenja došljakinja su pritom veća zbog nedostatka poznanstava 
i pomoći u čuvanju i odgoju djece. Iako je istraživanje pokazalo da su obiteljski odnosi izbalansirani i da muškarci podržavaju ženski rad isto ne znači da su one imale njegovu pomoć u kućanstvu. Pomoć je realizirana prilikom čuvanja djece ukoliko su majke ili svekrve bile u mogućnosti pomoći. Također, položaj žena u javnom društvenopolitičkom životu nije ostvaren u mjeri u kojoj bi se, uz proklamirani prestiž i neovisnost, očekivalo. Prema dostupnim kazivanjima samo se jedna tabacchina spominje kao aktivna antifašistkinja. Priče ostalih kazivačica i životne priče njihovih pretkinja vezane su uz rad u tvornici te nastavak rada u kući, a pojedinih i na polju. U kontekstu ovog rada zanimljivo je naglasiti zamjetan broj radnica kojima plaća (posebno u periodu međuraća) nije dovoljna u zadovoljavanju osnovnih obiteljskih potreba, pa su mnoge primorane dodatno raditi u polju. Takve informacije o tabacchinama dosad nisu zabilježene. Iste, međutim ne impliciraju izostanak emanipacijskog potencijala industrijskog rada. Činjenica da zarađuju i da mogu upravljati tom imovinom samostalno za kazivačice predstavlja realizaciju emancipacije.

Cjelodnevni plaćeni i neplaćeni rad radnicama ostavlja malo ili nimalo vremena za djecu. Djeca se s 45 dana predaju u tvorničke jaslice, a kasnije ih odgajaju bake ili ulica, a tek kasnije obavezna škola. Brigu i opterećenje kazivačice iskazuju upravo u kontekstu majčinstva. Iako su iskazi šturi, sve kazivačice koje su u Rovinj došle poslom, ukazuju na neusklađenost radnog vremena i fizičkog opterećenja s pravima rodiljskog dopusta i kasnije mogućnostima odgoja djece. Činjenica da vrtići i jaslice postoje svakako je olakšavajuća okolnost. Međutim, takva su rješenja ipak bila daleko od socijalne politike kakvu danas poznajemo.

Uz ekonomsku samostalnost, radnice su "osvojile" i dvostruku opterećenost. Ista se ogleda, kako je ranije navedeno, u nastavku teškog fizičkog rada u kući i na polju nakon onog tvorničkog. Procesi selekcije radnica upućuju nas na težinu posla za koji se prijavljuju. Osim dobrog vida i spretnih ruku, tražile su se snažne i mlade djevojke. Posebno su opterećene radnice u ribljoj industriji s obzirom na teške uvjete rada ne samo u smislu proizvodnih procesa već i uvjeta u kojima su se ti procesi odvijali; rad na hladnom i mokrom. S druge strane u tvornici duhana su uvjeti selekcije stroži jer je potrebna posebna vještina u ručnom motanju cigara koje se zadržava sve do 1945. 
Kontrapunktirajući povijesne izvore rezultatima terenskog rada, i to sjećanjima kao jednoj kategoriji i življenim iskustvima kao drugoj, te smještajući analizu u širi društveno-povijesni kontekst industrijalizacije, nastojala sam pokazati da se samoidentificirana i pretpostavljena emancipacija žena stjecala vlastitim izvorima prihoda, no da je ona bila moguća s obzirom na povijesno trajanje povoljnije pozicije žena u Rovinju u odnosu na neke druge zajednice u kojima se industrijski razvoj također temeljio na ženskoj radnoj snazi. To znači da industrijski, plaćeni rad nije isključivi preduvjet emancipacije. Ista se realizira samo u određenim društvenim i političkim okolnostima. Rovinjski primjer pokazuje da "ženski rad" nije samo instanca opresije i eksploatacije, već je istovremeno mjesto gdje je moguće konstruirati alternative; ženska radnička iskustva nisu samo ograničavajuća i prisilna, već postaju generatori mogućnosti (Weeks 2004: 187).

Kao doprinos potvrdi te teze, istraživanje je također pokazalo da ne postoji jedinstvena radnička pozicija, da je koncept klase fluidan i da se subordinacija dešava na nekoliko razina; rodna je samo jedna u nizu. Stoga je važno ustanoviti da ne postoji jedinstveni, pravilni obrazac po kojem se svaka sudbina može ravnati. Primjerice, u nekim su društvenim, kulturnim i političkim kontekstima dominantnije diskriminacije temeljene na ideološkoj pripadnosti ili onoj nacionalnoj, dok će u drugima dominirati one temeljene na rodu. Također, ista će karakteristika u različitim periodima, iako na istom radnom mjestu, geografskoj lokaciji ili zajednici, biti drugačije valorizirana. Vidjeli smo u radu primjere toga kako su i muškarci dobivali otkaze temeljem nacionalnosti koja je samo par godina ranije bila poželjna. Kombinacije intersekcija su mnogobrojne i uvijek se manifestiraju na onoliko načina koliko je aktera uključeno $\mathrm{u}$ međusobnu identifikaciju. Skeggs (2004) je na suvremenom primjeru pokazala kako radnice izbjegavaju identifikaciju s radničkom klasom jer je ono što se pod tim pojmom danas podrazumijeva (u specifičnoj mikrorealnosti u okviru koje je provedeno istraživanje) izrazito negativno. Međutim, u očima društva, u određenom kontekstu (vrijeme rada primjerice) one jesu radnička klasa. U drugim će povijesnim periodima, poput socijalizma, pripadnost radničkoj klasi biti smatrana svojevrsnim uspjehom te će se u većini slučajeva osobe ponositi takvim statusom. Intersekcijska analiza nije samo metoda ukazivanja na to kako se generiraju subordinirani položaji, ona nam, između 
ostalog, jasno ukazuje na važnost sagledavanja kombinacije konteksta unutar kojega se realizira subordinacija i distinktivnih karakteristika koje potencijalno mogu prouzročiti subordinirani položaj.

Raznolikost istraživačkih pozicija neminovno nameće pitanje koja je "prava istina" o istraživanome. Kroz analizu odabranih teorijskih okvira priklonila sam se stavu Donne Haraway, koja nudi tezu o parcijalnim, lociranim i kritičkim znanjima koja podržavaju mogućnost stvaranja mreže odnosa. Promišljanjem o ranjivostima unutar mreže intersubjektivnih odnosa kazivača, šireg subjekta istraživanja, ali i istraživačice, a s obzirom na činjenicu da se feministička objektivnost opire simplifikaciji i fiksaciji i da je "nezasitno znatiželjna otkrivati mrežu različitih pozicioniranja" (Haraway 1988: 584), kroz rad sam nastojala prikazati niz različitih pozicija i stajališta, i to ne kako bih relativizirala radnička iskustva, nego kako bih ukazala na nužnost parcijalnog i lociranog znanja koje je kritičko prema izvorima, ali i prema vlastitoj poziciji. Heterogenost informacija vezanih uz radnička iskustva artikulirane kroz prizmu intersekcije otkrivaju nam razine nejednakosti i podržavaju takvu teorijsko-metodološku orijentaciju.

Istraživanje koje sam provela pokazuje da su žene u odnosu na muškarce (rodna intersekcija) imale slabije plaćene poslove (ili pozicije), među ženama su postojale one koje su na temelju nacionalne pripadnosti (nacionalna intersekcija) lakše našle posao, a dodatno se među tvorničkim radnicama (klasna intersekcija) distinkcija utvrđivala i na temelju industrijske grane kojoj su pripadale. Odabrani analitički okvir intersekcionalizma je, dakle, posljedica terenskog istraživanja.

Istraživanje je zaokruženo analizom mehanizama prenošenja kulturnog pamćenja. Za te potrebe analizirane su povijesne fotografije radnica, folklorni sadržaj dviju pjesama, muzeološka djelatnost gradskog muzeja u odnosu na radničku povijest $\mathrm{i}$ koncept postava Muzeja duhana koji se usko veže uz korporativni diskurs TDR-a. Iz analiza primjećujemo da svi navedeni materijali imaju elemente subverzivnog potencijala s obzirom da otkrivaju stanja koja se inače prešućuju, predstavljajući kontrapunkt dominantnom narativu o radnicama, ali taj potencijal u svojoj, posebice 
materijalnoj, izvedbi nije uvijek dovoljno ili adekvatno prikazan.

Povijesne fotografije predstavljaju temelj za izgradnju imaginarija o radnicama koji odgovara romantičnim vizijama prošlosti. Fotografije datiraju u posljednje desetljeće 19. stoljeće te prate tvorničke uspjehe sve do kasnih 1920-ih. Iako je zbog tehnoloških dostignuća vjerojatno kako je s vremenom fotografija sve više, one u javnom diskursu o rovinjskim duhanskim radnicama izostaju. Režirane fotografije koje nam se serviraju predstavljaju odraz želja duhanskog monopola u predstavljanju ne samo ekonomskog već i uspjeha multietničkog carstva. Na fotografijama se ne vide sve žene, ali je zato strogo naglašena rodna hijerarhija. Ne vide se procesi rada ili prikaz svakodnevice, već se obilježavaju značajnije obljetnice. S druge strane, socijalizam otvara platformu za predstavljanje radnica riblje industrije koje se za razliku od ranijih duhanskih radnica fotografiraju u procesu rada. Te se fotografije dalje objavljuju $u$ udžbenicima na državnoj razini i doprinose stvaranju socijalističkog radničkog imaginarija.

Sličan mehanizam predstavljaju i tradicijske pjesme koje se redovito izvode kao dio repertoara lokalnog Kulturno umjetničkog društva. Pjesme ponavljaju stereotipe o bogatim i mušićavim radnicama i uvjetuju tako generaliziranje i homogeniziranje radničke prošlosti. Pritom, u folklornom se opusu još i snažnije osjećaju posljedice selektivnog pamćenja. Društvo u ovom slučaju prisvaja i pamti pozitivno, a ono što je negativno, iako pjeva, ne koristi u oblikovanju pamćenja na radnice. Naime, fotografije ne prikazuju negativno, pa je stvaranje pozitivne predodžbe lako shvatljivo. Međutim, pjesme su do nas došle necenzuriranog teksta, pa negativne konotacije saznajemo izravno, riječju.

Javnu kulturnu aktivnost na temu ženske radničke kulture Rovinja, uz izvođenje pjesama i tiskanje kalendara $\mathrm{s}$ fotografijama Rovinjki, među kojima su se našle $\mathrm{i}$ tabacchine, predstavljaju dvije fotografske izložbe koje u razmaku od 42 godine organizira Muzej grada Rovinja-Museo della citta di Rovigno'. Informacije koje su na izložbe prikazane ponavljanjem osnažuju stereotipe, a predstavljene su u skromnoj formi otisnutih fotografija i opisnih legendi. Iako je izložba mogla otvoriti prostor za 
propitivanje stavova građana na temu radničke prošlosti, emocija koje te fotografije potiču ili sjećanja radnica, to je izostalo. O razlozima takvog formata izložbe mogu govoriti samo kustosi, no možemo pretpostaviti da su i izložbe nerijetko bile u službi dominantnih ekonomsko-političkih i društvenih diskursa. Također, neki od mogućih razloga su i nedostatak izvora informacija ili tzv. autoriziran baštinski diskurs (usp. Laurajane Smith) koji predstavlja dominantan stručni (muzeološki) diskurs koji je u suprotnosti s istraživanjem odozdo i multivokalnosti zajednice.

Posljednji mehanizam koji sam dovela u vezu s kulturnim pamćenjem radnica vezan je uz korporativnu politiku TDR-a i korištenje radničkih identiteta u građenju korporativnog imidža. Isti je moguće iščitati kroz interne tvorničke časopise koji između ostalog predstavljaju i proces realizacije Muzeja duhana, upravo unutar tvorničkog kompleksa. Koncept je usmjeren na prezentaciju proizvodnih procesa kroz predstavljanje proizvoda i alatki korištenih u duhanskoj industriji, međutim diskurs koji se koristi u promociji vrijednosti tvornice se temelji na ljudskoj snazi i inovativnosti. Iako Muzej gotovo da $\mathrm{i}$ ne spominje radnice, pozitivan stav koji radnici imaju o tvornici, čak i danas, kada je TDR prešao u ruke British American Tobacco-a, podržava mit i sjećanje na prestižne radnice. Tomu je tako jer Tvornica i dalje zapošljava veliki broj lokalnog stanovništva te im pruža dobre radne uvjete i relativno visoke plaće.

Rad završavam analizom kulturnog pamćenja kroz stavove mojih suvremenika i koristim ih kao validatore radničkih iskustava. Na uzorku od 27 osoba obaju spolova u dobi od 20 do 70 godina, cilj je bio ustanoviti perzistira li mit o rovinjskim radnicama i dalje u svakodnevici i postoje li razlike u percepciji i valorizaciji sjećanja u odnosu na vrstu tvorničkog pogona - duhanskog ili prerade ribe. Važno je pritom naglasiti da je istraživanje provedeno među poznanicima za koje sam smatrala da bar djelomično poznaju lokalnu povijest; u protivnom upitnik ne bi bio uspješan jer nakon konstatacije da ne poznaju termine tabacchina ili sardellina ispitanici ne bi dalje mogli sudjelovati $u$ upitniku. Rezultati pokazuju da ispitanici u visokom postotku poznaju ove talijanske (i lokalne) termine, da ih, dakako, vežu uz materiu primu koja se u određenom pogonu koristi što je i najčešća asocijacija (tabacco-duhan, sardella-srdela). Odmah za tim ističu se senzorne asocijacije, prvenstveno one koje se tiču mirisa. Ključni dio upitnika 
veže se uz percepciju uvjeta rada u oba pogona. Nešto više ispitanika smatra da su uvjeti rada bili teži u Tvornici za preradu ribe, međutim razlike u postocima su zaista male. Prevladava mišljenje kako je rad bio težak u oba pogona i da je zaista uvjetovao emancipaciju žena.

Da Rovinj pamti rovinjske radnice ne svjedoče samo stanovnici koji se sjećaju. Zahvaljujući istaknutim pojedincima, Grad Rovinj-Rovigno radnicama je posvetio i pojedina mjesta $\mathrm{u}$ gradu. Trg Tabacchina se nalazi pred samom tvornicom, na nekadašnjem ulazu u pogon, a Stube Sardellina vode od kompleksa tvornice Mirna do Ulice Vijenac braće Lorenzetto. Ono što se danas pitam, s odmakom od nekoliko godina od samog početka istraživanja kada je tvornica još bila "rovinjska", a u biseru austrijske arhitekture su se, iako iza zatvorenih vrata, ipak čuvala sjećanja na jedno doba i jednu industriju koja je oblikovala generacije žena, jest nisu li upravo te spomeničke geste radnice ostavile u prošlosti? Dok nema potrebe za muzejom, praksa uglavnom živi, dok se ulica ne zove po njima, one su još uvijek tu. Rovinj je na simboličan način valorizirao povijest, no je li iz povijesti naučio lekcije za budućnost? Posebno, jesu li osviještena raznovrsna radnička iskustva nasuprot dominantnom homogenom imaginariju i 'dvostruko opterećenje' radnica u kontekstu emancipacijskog potencijala rada?

Prošla iskustva i današnje kulturno pamćenje, predstavljeni u ovom radu, uče nas o heterogenim radničkih identitetima i nizu faktora koji utječu na neravnopravne odnose među radnicima i radnicama. Plaćeni rad doprinosi emancipaciji s obzirom da pruža ekonomsku neovisnost, a to je činjenica koja vrijedi za sve radnike/ce i umirovljenike/ce. Za žene je takva neovisnost posebno važna s obzirom da su prije industrijalizacije razni oblici ženskog rada bili teško vidljivi, utječući tako na njihov nepovoljan društveni status. Zaključimo da je industrijski, masovni javni rad omogućio vidljivost ženskog rada. Međutim, razine opterećenosti koje žene u kontekstu plaćenog (industrijskog) rada trpe, nužno je snažnije osvijestiti upravo kao lekcije koje mogu poslužiti ravnopravnijim odnosima u budućnosti. Ako su do danas, barem zakonski, izjednačene mogućnosti muškaraca i žena pristupu obrazovanju i kasnije radu, lekcije koje predstoji naučiti tiču se iznalaženja rješenja za, primjerice, izjednačavanje rodnih 
obaveza vezanih uz socijalnu reprodukciju, ali i uvažavanje pojedinačnih potreba $\mathrm{s}$ obzirom na raznolikost pozicija iz kojih radnici/ce dolaze. 


\section{LITERATURA I IZVORI}

ABU-LUGHOD, Lila. 1991. "Writing Against Culture". U Recapturing Anthropology. Working in the Present. Richard G. Fox, ur. Santa Fe: School of American Research Press, 137-162.

AGUILAR, J. L. 1994. "Going Against the Grain. Comparison of Research at Home and Abroad". Etnofoor 7/1: 97-107.

ANIĆ, Rebeka Jadranka. 2010. Žene u Crkvi i društvu. Sarajevo, Zagreb: Svjetlo riječi.

ASSMAN, Aleida. 2011. Duga senka prošlosti. Kultura sećanja i politika povesti. Beograd: Biblioteka XX vek.

ASSMAN, Aleida. 2015. “Sećanje, individualno i kolektivno". U Kolektivno sećanje $i$ politike pamćenja. Michal Sládeček, Jelena Vasiljević i Tamara Petrović Trifunović, ur. Beograd: Zavod za udžbenike, 71-86.

ASSMANN, Jan. 2007. Kulturno pamćenje. Pismo, sjećanje i politički identitet u ranim visokim kulturama. Beograd: Prosveta.

AUGÉ, Marc. 2002. "Bliski drugi”. U Drugi i sličan. Martine Segalen, ur. Zagreb: Jesenski i Turk, 25-42.

BARADA, Valerija. 2013. "Primjena feminističke teorije stajališta u istraživanju ženskih profesionalnih biografija”. Revija za sociologiju 43/3: 199-222.

BENUSSI, Bernardo. 2004 [1888]. Storia documentata di Rovigno. Trst: Famia Ruvignisa.

BIĆANIĆ, Ivo. Kraj dugog 19. stoljeća. Druga industrijska revolucija. Objavljeno 18. 10. 2017. http://arhivanalitika.hr/blog/kraj-dugog-19-stoljeca-druga-industrijskarevolucija/ (pristup 30. 11. 2019.).

BILGE, Sirma. 2009. "Smuggling Intersectionality into the Study of Masculinity. Some Methodological Challenges". Rad prezentiran na međunarodnoj konferenciji Feminist Research Methods. An International Conference. University of Stockholm. BORJAN, Etami. 2013. Drugi na filmu. Etnografski film $i$ autohtono filmsko stvaralaštvo. Zagreb: Hrvatski filmski savez.

BOSAZZI, Gabriele. 2012. Rovigno d'Istria. Guida storica artistica e culturale. Trst: Famia Ruvignisa. 
BOŠKOVIĆ, Aleksandar. 2007. “Od teorije kulture ka objašnjenju sveta”. Kultura 118/119: 9-18.

BROWNE, Irene i Joya MISRA. 2003. "The Intersection of Gender and Race in the Labour Market”. Annual Review Sociology 29: 487-513.

BUDICIN, Marino. 1997. "Profilo storico delle attività economiche". Rovigno d'Istria. Trieste: Famia Ruvignisa.

BUDICIN, Marino i Antonio MICULIAN. 1984. "Le manifatture rovignesi nella seconda metà del secolo XIX". Zbornik radova znanstvenog skupa "Susreti na dragom kamenu". Viša ekonomska škola "Dr. Mijo Mirković", Pula

BURAWOY, Michael. 1979. Manufacturing Consent. Changes in the Labor Process under Monopoly Capitalism. Chicago: The University of Chicago Press.

BURKE, Peter (Berk, Piter). 1999. “Istorija kao društveno pamćenje!”. REČ 56/2: 8392.

CHRISTENSEN, Ann-Dorte i Sune Qvotrup JENSEN. 2012. "Doing Intersectional Analysis. Methodological Implications for Qualitative Research". NORA - Nordic Journal of Feminist and Gender Research 20/2: 109-125.

CRENSHAW, Kimberlé. 1989. "Demarginalizing the Intersection of Race and Seks. A Black Feminist Critique of Antidiscrimination Doctrine, Feminist Theory and Antiracist Politics". University of Chicago Legal Forum 1: Article 8.

CRENSHAW, Kimberle. 1991. "Mapping the Margins. Intersectionality, Identity Politics, and Violence against Women of Color". Stanford Law Review 43/6: 12411299.

ČAČINOVIČ, Nadežda. 2011. “Mizoginija u filozofskoj tradiciji”. U Ljudska prava žena. Razvoj na međunarodnoj $i$ nacionalnoj razini 30 godina nakon usvajanja Konvencije UN-a o uklanjanju svih oblika diskriminacije žena. Ivana Radačić i Jelka Vince Pallua, ur. Zagreb: Institut društvenih znanosti Ivo Pilar, 101-110.

ČALE FELDMAN, Lada, Ines PRICA i Reana SENJKOVIĆ, ur. 1993. Fear, Death and Resistance. An Ethnography of War. Croatia, 1991-1992. Zagreb: Institut za etnologiju i folkloristiku.

ČAPO ŽMEGAČ, Jasna. 2006. "Etnolog i njegove publike. O restituciji etnografskih istraživanja”. U Etnologija bliskoga. Poetika $i$ politika suvremenih terenskih 
istraživanja. Jasna Čapo Žmegač, Valentina Gulin Zrnić i Goran Pavel Šantek, ur. Zagreb: Institut za etnologiju i folkloristiku, Jesenski i Turk, 213-235.

DE BOVOAR, Simon (Simone de Beauvoir). 1982. Drugi pol, 1-2. Beograd: BIGZ.

DE LAURETIS, Teresa. 1986. "Feminist Studies/Critical Studies Issues, Terms, and Contexts". U Feminist Studies/Critical Studies. Teresa de Lauretis, ur. Bloomington: Indiana University Press, 1-19.

DŽEBA, Krešimir. 1987. Duhanski put u Rovinj. Rovinj: Tvornica duhana Rovinj. DUKOVSKI, Darko. 2010. "Gospodarski i socijalni odnosi na Rovinjštini početkom XX. stoljeća”. U Seljanski zbornik. Branimir Crljenko, ur. Rovinj. HKD Franje Glavinića i Ogranak Matice hrvatske Rovinj, 160-173.

ĐURIN, Sanja, Renata JAMBREŠIĆ KIRIN i Tea ŠKOKIĆ. 2019. “Od antropologije žene do rodne ideologije". Glasnik Etnografskog instituta SANU 67/2: 231-245.

ENGELS, Friedrich. 2004 [1891]. The Origin of the Family, Private Property and the State. Resistance Books.

FAVRET-SAADA, Jeanne. 2012. "Being Affected". HAU. Journal of Ethnographic Theory 2/1: 435-445.

FEDERICI, Silvia. 1975. Wages Against Housework. Bristol: Falling Wall Press and the Power of Women Collective.

FERBER, Marianne A. i Julie A. NELSON. 2003. Feminist Economics Today. Beyond Economic Man. Chicago: The University of Chicago Press.

FELLNER, Sabine i Georg THIEL. 2009. Nicotiana. European Smoking Culture. Beč: Sonderzahl.

GAVRILOVIĆ, Ljiljana. 2004. Balkanski kostimi Nikole Arsenovića. Beograd: Etnografski institut SANU.

GEERTZ, Clifford. 1973. The Interpretation Of Cultures. New York: Basic Books.

GILMAN, Charlotte Perkins. 2012. Women and Wconomics. digireads.com.

GROSS, Mirjana. 1993. “"Nevidljive’ žene”. Erasmus 3: 56-64.

GROSS, Mirjana. 2006. "O historigrafiji posljednjih trideset godina”. Časopis za suvremenu povijest 38/2: 583-609.

GRUBIĆ, Predrag. 1999. "Multimedijalna prezentacijska tehnologija”. td magazin, 3031. 
GULIN ZRNIĆ, Valentina. 2005. "Domaće, vlastito i osobno. Autokulturna defamilijarizacija". Narodna umjetnost 42/1: 161-181.

HADAR, Gila. 2007. "Jewish Tobacco Workers in Salonika. Gender and Family in the Context of Social and Ethnic Strife". U Women in the Ottoman Balkans. Gender, Culture and History. Amila Butrović i Irvin Cemil Schick, ur. London: I.B. Tauris, $127-152$.

HALBWACHS, Maurice (Albvaks Moris). 2013. Društveni okviri pamćenja. Novi Sad: Mediterran Publishing.

HARAWAY, Donna. 1988. "Situated Knowledges. The Science Question in Feminism and the Privilege of Partial Perspective". Feminist Studies 14/3: 575-599.

HARAWAY, Donna. 1985. “A Manifesto for Cyborgs”. monoskop.org: 65-107

HARDING, Sandra. 1986. The Science Question in Feminism. Ithaca, London: Cornell University Press.

HARDING, Sandra. 1987. Feminism and Methodology. Bloomington: Indiana University Press.

HARDING, Sandra. 1991. Whose Science? Whose Knowledge? Thinking from Women's Lives. Ithaca: Cornell University Press.

HARDING, Sandra. 1992. "Rethinking Standpoint Epistemology. 'What is Strong Objectivity'?". The Centennial Review 36/3: 437-470.

HARDING, Sandra, ur. 1993. The 'Racial' Economy of Science. Toward a Democratic Future. Bloomington, Indianapolis: Indiana University Press.

HARDING, Sandra, ur. 2004. The Feminist Standpoint Theory Reader. Intellectual and Political Controversies. New York, London: Routledge.

HARTMANN, I. Heidi. 1984. "The Unhappy Marriage of Marxism and Feminism. Towards a More Progressive Union”. U Feminist Frameworks. Alternative Theoretical Accounts of the Relations Between Women and Men. Allison M. Jaggar i Paula S. Rothenberg, ur. New York: McGraw-Hill, 172-189.

HARTSOCK, Nancy C. M. 1983. Money, Sex, and Power. Toward a Feminist Historical Materialism. New York: Longman's.

HEKMAN, Susan. 1997. "Truth and Method. Feminist Standpoint Theory Revisited". Signs 22/2: 341-365. 
HILl COLLINS, Patricia. 1990. Black Feminist Thought. Knowledge, Consciousness, and the Politics of Empowerment. New York, London: Routledge.

HOBSBAWM, Eric. 1999. Industry and Empire. London: Penguin Books.

HUNTING, Gemma et al. 2014. “An Intersectionality-Based Policy Analysis

Framework. Critical Reflections on a Methodology for Advancing Equity". International Journal for Equity in Health 13/119.

ISAAC, Barry L. 2005. "Karl Polanyi”. U A Handbook of Economic Anthropology. James G. Carrier, ur. Cheltenham , Northampton: Edward Elgar Publishing, 14-25.

JAGGAR, Alison M. i Paula S. ROTHENBERG, ur. 1984. Feminist Frameworks. Alternative Theoretical Accounts of the Relations Between Women and Men. New York: McGraw-Hill.

JAMBREŠIĆ-KIRIN, Renata i Tea ŠKOKIĆ, ur. 2004. Između roda $i$ naroda. Etnološke i folklorističke studije. Zagreb: Institut za etnologiju i folkloristiku, Centar za Ženske studije.

JAMBREŠIĆ KIRIN, Renata i Marina BLAGAIĆ. 2013. “Ambivalentno nasljeđe socijalističkih radnica. Slučaj tvornice Jugoplastika”. Narodna umjetnost 50/1: 40-73.

JELINČIĆ, Jakov. 2006. "Matične knjige umrlih važan izvor za povijest zdravstva (Primjer matičnih knjiga umrlih župe Vodnjan od 1815. do 1893.)”. U Identitet Istre. Ishodišta i perspektive. Marino Manin et al., ur. Zagreb: Institut društvenih znanosti Ivo Pilar, 523-559.

KALE, Jadran. 1995/1996. "Nadnaravni karakter žene ocrtan otočnim predajama šibenskog kraja”. Ethnologica Dalmatica 4-5: 83-107.

KANDLER, Pietro. 1853. Statuti municipali di Rovigno.

KARBIĆ, Marija. 2004. "Nije, naime njezina duša drugačija nego kod muškarca". Položaj žene u gradskim naseljima međurječja Save i Drave u razvijenom i kasnom srednjem vijeku". U Žene u Hrvatskoj. Ženska i kulturna povijest. Andrea Feldman, ur. Zagreb: Institut Vlado Gotovac, Ženska infoteka, 57-76.

KIRBY, Peter. 2003. Child Labour in Britain, 1750-1870. New York: Palgrave Macmillan .

KOLAR-DIMITRIJEVIĆ, Mira. 1979. "Tvornica duhana u Senju i njeno radništvo od godine 1918. do 1941.”. Senjski zbornik : prilozi za geografiju, etnologiju, gospodarstvo, povijest i kulturu, Vol. 7 No. 1, 39-58. 
KONDO, Dorinne K. 1990. Crafting Selves. Power, Gender, and Discourses of Identity in a Japanese Workplace. Chicago: University of Chicago Press.

KRVOPIĆ, Lana. 2013. “Matična knjiga krštenih župe Tinjan 1847.-1880.”. Vjesnik istarskog arhiva 20: 39-58.

LÉVI-STRAUSS, Claude. 2011 [1955]. Tužni tropi. Beograd: Zepter Book World.

MALINOWSKI, Bronislaw. 1979 [1922]. Argonauti Zapadnog Pacifika. Beograd: BIGZ, Biblioteka XX vek.

MANZ, Beatriz. 1995. "Reflections on an 'Anthropología Comprometida'. Conversations with Richard Falla”. U Fieldwork under Fire. Contemporary Studies of Violence and Survival. Carolyn Nordstrom i Antonius C. G. M. Robben, ur. Berkeley, Los Angeles: University of California Press, 261-274.

MARCH, James G. i Herbert A. SIMON. 1958. Organizations. New York: Wiley. MARGETIĆ, Lujo. 1970. "Brak na istarski način”. Vjesnik historijskih arhiva u Rijeci $i$ Pazinu 15/(1970): 279-308.

MARIĆ, Katarina. 2015. Prikaz. ”E ciume, ciume, son tabacheina...: Izložba -

Rovinjske tabakine na starim fotografijama. Zavičajni muzej grada Rovinja-Museo civico della citta di Rovigno. Rovinj." Histria, 5, 370-373.

MARSETIČ, Raul. 2016. "La Regia Manifattura tabacchi Pola.” Quaderni XXVII, 81139.

MATOŠEVIĆ, Andrea. 2011. Pod zemljom. Antropologija rudarenja na Labinštini u $X X$. stoljeću. Zagreb, Pula: Institut za etnologiju i folkloristiku, Sveučilište Jurja Dobrile u Puli.

MATOŠEVIĆ, Andrea. 2015. Socijalizam s udarničkim licem. Etnografija radnog pregalaštva. Zagreb, Pula: Institut za etnologiju i folkloristiku, Sveučilište Jurja Dobrile u Puli.

McDOWELL, Linda. 2006. "Reconfigurations of Gender and Class Relations. Class

Differences, Class Condescension and the Changing Place of Class Relations". Antipode 38/4: 825-850.

McDOWELL, Linda. 2014. "Border Crossings. Reflections on Women's Lives in Twentieth-Century Britain”. Gender, Place \& Culture 21/2: 152-173.

MEAD, Margaret. 2004 [1950]. Spol i temperament u tri primitivna društva. Zagreb: Jesenski i Turk. 
MIES, Maria. 1991. “Women's Research or Feminist Research? The Debate Surrounding Feminist Science and Methodology". U Beyond Methodology. Feminist Scholarship as Lived Research. Mary Margaret Fonow i Judith A. Cook, ur. Bloomington: Indiana University Press, 60-84.

MIES, Maria i Vandana SHIVA, ur. 2014. Ecofeminism. London, New York: Zed Books.

MIHALJEVIĆ, Damirka. 2016. “Feminizam. Što je ostvario?”. Mostariensia 20/1-2: 149-169.

MOGOROVIĆ CRLJENKO, Marija. 2006. Nepoznati svijet istarskih žena. Položaj $i$ uloga žene u istarskim komunalnim društvima. Primjer Novigrada u 15. i 16. stoljeću. Zagreb: Srednja Europa.

MOGOROVIĆ CRLJENKO, Marija. 2012. Druga strana braka. Nasilje i ilegitimnost u (izvan)bračnim vezama na području Porečke biskupije u prvoj polovici 17. stoljeća. Zagreb: Srednja Europa.

MOGOROVIĆ CRLJENKO, Marija i Danijela DOBLANOVIĆ. 2015. "Stanovništvo Rovinja prema najstarijoj matičnoj knjizi vjenčanih (1564.-1640.)". Povijesni prilozi 34/49: 239-272.

MOORE, Henrietta L. 1988. Feminism and Anthropology. Cambridge: Polity Press. MURAJ, Aleksandra. 2004. "Samostalnost i/ili podređenost. Ambivalencija društvenog položaja žena na Zlarinu”. U Između roda i naroda. Etnološke i folklorističke studije. Renata Jambrešić-Kirin i Tea Škokić, ur. Zagreb: Institut za etnologiju i folkloristiku, Centar za ženske studije, 85-96.

MUSTAJBEGOVIC, Jadranka; Eugenija ZUSKIN, E. Neil SCHACHTER, Josipa KERN, Marijana LUBURIC-MILAS i Jasna PUCARIN. 2003. "Respiratory Findings in Tobacco Workers”. Chest Journal 123: 1740-1748 (preuzeto 28. 9. 2011.).

NARAYAN, Kirin. 1993. "How Native Is a 'Native' Anthropologist?”. American Anthropologist, New Series, 95/3: 671-686.

NEMEC, Gloria. 2012. Nascita di una minoranza. Istria 1947-1965. Storia e memoria degli italiani rimasti nell'area istro-quarnerina. Etnia XIV, Rovigno: Centro di ricerche storiche, Rovigno / Unione italiana, Fiume / Università popolare, Trieste / Università degli studi - Dipartimento studi umanistici, Trieste. 
NIKOLIĆ ĐERIĆ, Tamara. 2015. “Tobacco Industry Changing Lives. Women Workers at the Turn of the 20st Century". Narodna umjetnost 52/1: 173-188.

NIKOLIĆ ĐERIĆ, Tamara. 2017. Vizualna etnografija Istre. Izbor iz fundusa Etnografskog muzeja Istre. Pazin: EMI.

OGRAJŠEK GORENJAK, Ida. 2014. Opasne iluzije. Rodni stereotipi u međuratnoj Jugoslaviji. Zagreb: Srednja Europa.

PAPIĆ, Žarana i Lydia SKLEVICKY, ur. 2003. Antropologija žene. Beograd: Biblioteka XX vek.

PARENT, M., J. HAMMER, T. BRADSTREET, E. SCHWARTZ i T. JOBE. 2018. "Men's Mental Health Help-Seeking Behaviours. An Intersectional Analysis". American Journal of Men's Health 12/1: 64-73.

PARRY, Jonathan. 2005. "Industrial Work". U A Handbook of Economic Anthropology. James G. Carrier, ur. Cheltenham, Northampton: Edward Elgar Publishing.

POTKONJAK, Sanja. 2014. Teren za etnologe početnike. Zagreb: HED biblioteka, FF press.

PRICA, Ines. 2004. “Žene obavljaju muški posao. Rod i autoritet u hrvatskoj etnologiji”. U Između roda i naroda. Etnološke i folklorističke studije. Renata Jambrešić Kirin i Tea Škokić, ur. Zagreb: Institut za etnologiju i folkloristiku, 33-48.

RABINOW, Paul. 1977. Reflections on Fieldwork in Morocco. Berkley: University of California Press.

RABINOW, Paul. 1986. "Representations are Social Facts. Modernity and PostModernity in Anthropology". U Writing Culture. The Poetics and Politics of Ethnography. James Clifford i George G. Marcus, ur. Berkley: University of California Press, 234-261.

RADIĆ, Antun. 1897. Osnove za sabiranje i proučavanje građe o narodnom životu. Zagreb: Tisak Dioničke tiskare.

RAMAZZINI, Bernardino (1633.-1714.). 1964. Diseases of Workers. New York: Hafner Publishing Company.

RENTETZI, Maria. 2008. “Configuring Identities Through Industrial Architecture and Urban Planning. Greek Tobacco Warehouse in Late Nineteenth and Early Twentieth Century". Social Studies 21/ 1: 64-81. 
ROUHANI, Setareh. 2014. Intersectionality-Informed. Quantitative Research. A Primer. The Institute for Intersectionality Research \& Policy, SFU.

ROY, Donald. 1952. Restriction of Output by Machine Operators in a Piecework Machine Shop. University of Chicago (doktorska disertacija).

SACKS, Karen. 1975. "Engels Revisited. Women, the Organization of Production, and Private Property". U Toward an Anthropology of Women. Rayna R. Reiter, ur. New York: Monthly Review Press, 211-234.

SELLA, A. i M. SELLA. 1940. "L'industria del Trepang". Thalassia (Venice) 4/5: 1116.

SENJKOVIĆ, Reana. 2018. "Ugljen i šminka. Narativi o jugoslavenskoj radnici na ponudi posttranzicijskom sjećanju.” Etnološka tribina 41, vol. 48, 174-193.

SKEGGS, Beverley. 1997. Formations of Class and Gender. Becoming Respectable. London, Thousand, New Delhi: Sage Publications.

SKEGGS. Beverly. 2004. "Class, Self, Culture”. London, New York: Routledge.

SKLEVICKY, Lydia. 1996. Konji, žene, ratovi. Zagreb: Ženska infoteka.

SLÁDEČEK, Michal, Jelena VASILJEVIĆ i Tamara PETROVIĆ TRIFUNOVIĆ. 2015. Kolektivno sećanje i politike pamćenja. Beograd: Zavod za udžbenike.

SMITH, Laurajane. 2011. All Heritage is Intangible: Critical Heritage Studies and Museums. Text of the Reinwardt Memorial Lectures. Reinwardt Academy. Amsterdam School of the Arts.

SPECIAL EUROBAROMETER 465, Summary. Gender Equality 2017. Gender Equality, Stereotypes, and Women in Politics.

STIVENS, Maila. 2005. “Gender”. U A Handbook of Economic Anthropology. James G. Carrier, ur. Cheltenham, Northampton: Edward Elgar Publishing, 323-338. STRATHERN, Marilyn. 1987. "The Limits of Auto-Anthropology". U Anthropology at Home. Anthony Jackson, ur. London, New York: Tavistock Publications, 59-67. ŠKOKIĆ, Tea. 2001. "Feministička antropološka kritika. Od univerzalizma do razlike". Etnološka tribina 24/31: 5-20.

ŠKOKIĆ, Tea. 2004. "Feministička antropološka kritika. Od univerzalizma do razlike". U Između roda i naroda. Etnološke i folklorističke studije. Renata Jambrešić Kirin i Tea Škokić, ur. Zagreb: Institut za etnologiju i folkloristiku, 17-32. 
ŠKRBIĆ ALEMPIJEVIĆ, Nevena, POTKONJAK, Sanja i Tihana RUBIĆ. 2016. Misliti etnografski. Kvalitativni pristupi i metode u etnologiji i kulturnoj antropologiji. Zagreb: HED biblioteka, FF press.

TADEJ, Perla. 1983. "Mogućnosti i perspektive promatranja sa sudjelovanjem". Revija za sociologiju 13/1-4: 81-94.

THOMPSON, James D. 1967. Organizations in Action. New York: McGraw Hill. UJČIĆ, Tajana. 2014. E ciume, ciume, son tabacheina...: Izložba - Rovinjske tabakine na starim fotografijama. Zavičajni muzej grada Rovinja-Museo civico della citta di Rovigno. Rovinj.

VALIĆ, Fedor, Dunja BERITIĆ i Dragan BUTKOVIĆ. 1976. "Respiratory Response to Tobacco Dust Exposure". American Review of Respiratory Disease 113/6: 751-755.

VLAHOV, Dražen. 1992-1993. "Matične knjige u Povijesnom arhivu u Pazinu”. Vjesnik Istarskog arhiva 2-3/2-3: 277-309.

VLAJO, Radmila. 1999. Tvornica duhana Zagreb. td magazin 5/1-8.

VUKUŠIĆ, Ana-Marija. 2013. U sridu. Sjećanje, pamćenje $i$ život Alke. Zagreb: Institut za etnologiju i folkloristiku.

WARNER, W. Lloyd i J. O. LOW. 1947. The Social System of a Modern Factory. The Strike. A Social Analysis. New Haven: Yale University Press.

WOODWARD, Joan. 1958. Management and Technology. London: HMSO.

ZAHARIJEVIĆ, Adrijana. 2012. “Kratka istorija sporova. Šta je feminizam?” U Neko je rekao feminizam? Kako je feminizam uticao na žene XXI veka. Adrijana Zaharijević, ur. Novi Sad: Heinrich Böll Stiftung, Artprint, 368-402.

ZULIANI, Francesco M. 2008. L'Esodo da Rovigno. Storie, testimonianze, racconti. Trieste: Famìa Ruvignisa.

\section{NEOBJAVLJENI IZVORI}

Knjiga radnica TDR-a iz 1872. Arhiva Adris grupe d.d.

Novi stalni postav Etnografskog muzeja Istre-Museo etnografico dell’Istra, muzeološka koncepcija, grupa autora

dr. sc. Dario Pavić, "Uzorci i uzorkovanja-kvantitativne metode istraživanja", neobjavljeno predavanje 


\section{INTERNETSKI IZVORI}

https://archive.org/details/feministframewor00mcgr, pristup 3. 11. 2017.

https://ec.europa.eu/commfrontoffice/publicopinion/index.cfm/ResultDoc/download/Do cumentKy/80678, pristup 29. 11. 2019.

https://eige.europa.eu/gender-equality-index/2017, pristup 1. 9. 2019.

https://eige.europa.eu/gender-equality-index/2017/HR, pristup 1. 9. 2019.

familysearch.org, pristup 20. 11. 2019.

1816. do 1890. (knjiga rođenih)

1825. do 1907. (knjiga vjenčanih)

1836. do 1913. (knjiga umrlih)

https://www.istrapedia.hr/hr/natuknice/3945/fabretto-carlo/, pristup 1.10.2019.

https://www.istrapedia.hr/hrv/298/mirna-dd-rovinj/istra-a-z/, pristup 5. 11. 2019.

https://www.istrapedia.hr/hrv/852/rovinj/istra-a-z/, pristup 25. 11. 2019.

http://odraz.hr/media/291518/globalni\%20ciljevi\%20odrzivog\%20razvoja\%20do\%202

030 web.pdf, pristup 1. 9. 2019.

http://struna.ihjj.hr/naziv/metoda-snjezne-grude/20469/\#naziv, pristup 10. 10. 2019.

https://tehnika.lzmk.hr/mirna-d-d/, pristup 1.09.2019.

https://voxfeminae.net/autorice/ivana-mihaela-zimbrek/, pristup 25. 11. 2019.

http://www.enciklopedija.hr/natuknica.aspx?id=10348, pristup 25. 11. 2019.

http://www.enciklopedija.hr/natuknica.aspx?ID=16318, pristup 1. 11. 2019.

https://www.iep.utm.edu/fem-stan/, pristup 2. 11. 2019.

https://www.youtube.com/watch?v=xOAMc12PqmI, pristup 15. 5. 2016.

\section{FILMOGRAFIJA}

Kolić, Dušan u TV emisiji “20 miliona - sve zbog jednog cigarilosa” (RTS Trezor), Rovinj, 1968. 


\section{ŽIVOTOPIS AUTORICE}

TAMARA NIKOLIĆ ĐERIĆ - CURRICULUM VITAE

E-pošta: tnikolicdjeric@gmail.com

Tamara Nikolić Đerić rođena je 19. prosinca 1983. godine u Puli u Hrvatskoj. Osnovnoškolsko i gimnazijsko obrazovanje stekla je u Rovinju. Na Filozofskom fakultetu Sveučilišta u Zagrebu akademske godine 2002./2003. upisala je studij etnologije i kulturne antropologije i indologije, koji je završila 2007. godine. Nakon završetka studija, 2009. godine, upisala je poslijediplomski doktorski studij etnologije i kulturne antropologije na Odsjeku za etnologiju i kulturnu antropologiju na istom fakultetu. Od 2008. godine zaposlena je u Etnografskom muzeju Istre gdje kao kustosica vodi nekoliko zbirki: Društvena i duhovna kultura, Razglednice, čestitke i pisma, Fotografije, Grafike i Ostavštine. Osim toga, rad u Muzeju uključuje i dokumentarističku djelatnost iz područja fotografije i filma kao i ulogu voditeljice projekta Digitalizacije muzejske građe. Njezina raznolika i bogata muzejska djelatnost obuhvaća autorstvo nekoliko izložbi (Iz etnološkog rakursa, Rovinj, Bale, 2009.; Kalkuta 1945 - Dnevnik jednog vojnika, Indijski kulturni centar, 2012.; Fotografija između etnografije i egzotizacije, CVU Batana, 2013.) te stručne i znanstvene radove. Tamara Nikolić Đerić je pokretačica i voditeljica Međunarodnog festivala etnografskog filma - ETNOFILm u Rovinju (od 2009.), a od 2014. godine i kustosica i stručnoprogramska voditeljica Ekomuzeja Batana, također u Rovinju. Aktivna je članica strukovne i znanstvene organizacije Hrvatsko etnološko društvo (HED). Govori, čita i piše engleski, talijanski te španjolski jezik. Znanstveni interes usmjerava prema feminističkoj i vizualnoj antropologiji. 


\section{POPIS STRUČNIH I ZNANSTVENIH RADOVA (IZBOR)}

Nikolić, Tamara. 2009. "Valiže i deštini. Istra izvan Istre”. Informatica Museologica, 20-28.

Nikolić Đerić, Tamara. 2011. “Tabacheine. Žene u duhanskoj industriji”. Zbornik 11. hrvatsko-slovenske etnološke paralele. Ljubljana: Slovensko etnološko društvo, 274286.

Nikolić Đerić, Tamara. 2011. "Važnost sekundarne dokumentacije u etnografskim muzejima. Pitanje informatičke pismenosti i ljudskog faktora te uspostave normi i standarda pri obradi sekundarne dokumentacije”. Etnološka istraživanja 16: 79-90.

Nikolić Đerić, Tamara. 2012. "Istra u putopisu Charlesa Yriartea. Analiza putopisa kao književnog teksta i teksta kulture”. Etnološka tribina 42/35: 137-150.

Nikolić Đerić, Tamara. 2015. “Tobacco Industry Changing Lives. Women Workers at the Turn of the 20st Century". Narodna umjetnost 52/1: 173-188.

Nikolić Đerić, Tamara. 2015. “Ženska strana duhana. Društveno-povijesni aspekti razvoja rovinjske duhanske industrije i njen emancipativni potencijal". Gdje ima dima (katalog). Zagreb: Etnografski muzej. 